\title{
EVALUASI TATA HIJAU JALUR HIJAU JALAN KOTA PEKANBARU
}

\author{
OLEH \\ JANIA RIZKA \\ A44050159
}

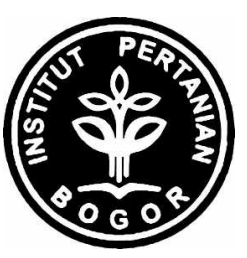

DEPARTEMEN ARSITEKTUR LANSKAP

FAKULTAS PERTANIAN

INSTITUT PERTANIAN BOGOR

2009 


\section{RINGKASAN}

\section{JANIA RIZKA, Evaluasi Tata Hijau Jalur Hijau Lanskap Kota Pekanbaru. (Dibimbing oleh NIZAR NASRULLAH).}

Jalur hijau kota Pekanbaru didominasi penanaman pohon dengan berbagai macam bentuk tajuk dan juga penanaman perdu dan penutup tanah dengan berbagai macam pola. Evaluasi terhadap tata hijau pada lanskap jalan dilakukan untuk meningkatkan dan mengembangkan tata hijau pada lanskap jalan. Penelitian bertujuan untuk mengevaluasi aspek fungsi, estetika dan pengelolaan jalur hijau dan memberikan rekomendasi peningkatan fungsi, estetika dan pengelolaan tata hijau jalur hijau jalan. Penelitian ini bermanfaat memberikan masukan kepada perencana, perancang dan penegelola dalam mengembangkan jalur hijau jalan kota Pekanbaru.

Metode evaluasi yang digunakan untuk aspek fungsi dan pengelolaan yaitu sesuai dengan kriteria berdasarkan referensi dalam bidang arsitektur lanskap yang dimasukkan ke dalam bentuk persentase pembobotan nilai dengan kategori sangat baik, baik, sedang dan rendah. Jalan yang dievaluasi terdiri dari 4 jalan (Jalan Cut Nyak Dien, Sudirman, Gajah Mada, Diponogero) yang dibagi kedalam 17 segmen jalan. Aspek fungsi tanaman yang dievaluasi berjumlah 7 yang terdiri dari ; fungsi pengarah, fungsi pembatas, fungsi peneduh, kontrol bunyi, kontrol cahaya, kontrol polusi, dan pemberi identitas. Aspek pengelolaan yang dievaluasi yaitu segi desain dan teknis.

Metode evaluasi yang digunakan untuk aspek estetika menggunakan teknik SBE (Scenic Beauty Estimation). Responden yang dilibatkan adalah mahasiswa dengan latar belakang ilmu arsitektur lanskap. Penilaian dilakukan berdasarkan penataan tanaman pada jalur hijau jalan di lapang yaitu terdapat 3 kategori pohon massal sejenis, pohon kelompok campuran, dan massal campuran (pohon-perdu-penutup tanah).

Hasil evaluasi seluruh aspek fungsional tanaman pada tiap segmen jalan menunjukkan kategori sangat baik yaitu Jalan Sudirman segmen 6 (81,9\%). Kategori baik berjumlah 13 segmen jalan dengan nilai berkisar dengan nilai antara 
65,2\% - 78,9\% yaitu Jalan Cut Nyak Dien segmen 1, 3, 4, jalan Sudirman segmen 1, 2, 3, 4, 5, 7, 8, dan Jalan Diponegoro segmen 1, 3, 4. Kategori sedang terdiri dari 3 segmen yaitu Jalan Cut Nyak Dien segmen 2 (49,5\%), Jalan Gajah Mada $(59,4 \%)$ dan Jalan Diponegoro segmen 2 (59,6\%). Segmen jalan dengan kategori sangat baik perlu dipertahankan dan dijaga pemeliharaannya, segmen dengan kategori baik dan sedang perlu ditingkatkan pemenuhan kriteria.

Hasil evaluasi aspek estetika menghasilkan nilai SBE untuk tiap lanskap. Lanskap pohon massal sejenis yang termasuk kedalam nilai SBE kategori tinggi yaitu lanskap 10 (Jalan Diponegoro Segmen 3), 12 (Jalan Sudirman segmen 8), 15,16 dan 21 (Jalan Sudirman segmen 6), 17, 18, dan 20 (Jalan Sudirman Segmen 7). Keindahan tinggi pohon massal sejenis ditunjukkan dengan penanaman pohon secara massal seragam (tinggi, warna, tekstur, bentuk), berkesinambungan dan jarak rapat. Pada pohon kelompok campuran, nilai SBE kategori tinggi yaitu lanskap 8, 10, 11. Keindahan tinggi pohon kelompok campuran ditunjukkan dengan penanaman kelompok pohon yang saling mendukung dan komposisi yang baik (tinggi, warna, tekstur, bentuk). Pada massal campuran, nilai SBE kategori tinggi yaitu lanskap 6, 14, 15, 16, 21, 25. Pada kategori keindahan pemandangan sedang dan rendah disebabkan belum terpenuhinya kriteria penanaman dan prinsip desain penataan tanaman.

Hasil seluruh evaluasi aspek pengelolaan tiap segmen menunjukkan kategori baik berjumlah 16 dengan nilai berkisar 56,3\% - 77,1\% yaitu Jalan Cut Nyak Dien segmen 1, 2, 3, 4, Jalan Sudirman segmen 1, 2, 3, 5, 7, 8, Jalan Gajah Mada, dan Jalan Cut Nyak Dien segmen 1, 2, 3, 4. Kategori sedang yaitu Jalan Sudirman segmen $4(56,3 \%)$. Segmen jalan dengan kategori baik dan sedang perlu untuk ditingkatakan pemenuhan kriteria.

Pada lanskap yang telah memenuhi kriteria fungsi, estetika, dan pengelolaan perlu untuk dipertahankan keberadaannya dan untuk lanskap yang belum baik diperlukan peningkatan untuk memenuhi kriteria fungsi, estetika dan pengelolaan. Pengelolaan yang baik dan teratur dibutuhkan untuk menjaga keberlangsungan lanskap. Kriteria fungsi, estetika dan pengelolaan dapat menjadi acuan untuk menghasilkan suatu lanskap jalan yang baik. 


\title{
LEMBAR PENGESAHAN
}

Judul

: EVALUASI TATA HIJAU JALUR HIJAU JALAN

KOTA PEKANBARU

Nama

: Jania Rizka

NRP

: A44050159

Departemen

: Arsitektur Lanskap

Menyetujui :

Dosen Pembimbing

\section{Dr. Ir. Nizar Nasrullah, M.Agr.}

\author{
NIP. 196201181986011001
}

Mengetahui :

Ketua Departemen Arsitektur Lanskap

Prof. Dr. Ir. Hadi Susilo Arifin, MS

NIP. 195911061985011001

Tanggal Lulus 


\title{
EVALUASI TATA HIJAU JALUR HIJAU JALAN KOTA PEKANBARU
}

\author{
Skripsi sebagai salah satu syarat \\ untuk memperoleh gelar Sarjana Pertanian \\ pada Fakultas Pertanian Institut Pertanian Bogor \\ OLEH \\ JANIA RIZKA \\ A44050159

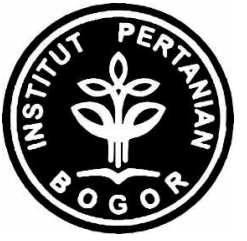

DEPARTEMEN ARSITEKTUR LANSKAP

FAKULTAS PERTANIAN

INSTITUT PERTANIAN BOGOR

2009 


\section{RIWAYAT HIDUP}

Penulis dilahirkan di Pekanbaru, Riau pada tanggal 5 Januari 1987. Penulis adalah anak pertama dari tiga bersaudara pasangan Zahari, ST dan Syafrida.

Penulis memulai pendidikan di TK Pertiwi Propinsi Pekanbaru. Penulis menamatkan Sekolah Dasar di SD Negeri 014 Pekanbaru, Sekolah Menengah Pertama di SMP Negeri 4 Pekanbaru, dan Sekolah Menengah Atas di SMA Negeri 1 Pekanbaru. Pada tahun 2005 penulis menamatkan pendidikan di SMU 1 dan pada tahun yang sama diterima di Institut Pertanian Bogor melalui jalur SPMB. Pada tahun 2006 penulis diterima di Departeman Arsitektur Lanskap, Fakultas Pertanian.

Selama menuntuk ilmu di IPB, penulis aktif dalam kepanitian pada acara di dalam lingkup Arsitektur Lanskap dan menjadi asisten praktikum mata kuliah Tanaman Dalam Lanskap. Penulis menyelesaikan skripsi berjudul Evaluasi Tata Hijau Jalur Hijau Jalan Kota Pekanbaru sebagai syarat menjadi Sarjana Pertanian IPB dibawah bimbingan Dr. Ir. Nizar Nasrullah, M.Agr. 


\section{KATA PENGANTAR}

Puji syukur dihaturkan kehadirat Allah SWT atas berkah dan rahmat yang diberikan Nya, sehingga penelitian yang berjudul "Evaluasi Tata Hijau Jalur Hijau Jalan Kota Pekanbaru" ini dapat diselesaikan dengan baik.

Penulis menyampaikan ucapan terima kasih kepada pihak-pihak yang telah membantu dalam pelaksanaan penelitian dan penulisan skripsi. Ucapan terima kasih penulis ditujukan kepada:

1. Dr. Ir. Nizar Nasrullah, MAgr selaku dosen pembimbing yang telah memberikan bimbingan dan pengarahan selama kegiatan penelitian dan penulisan skripsi ini.

2. Dr. Ir. Afra D.N. Makalew, MSc dan Ir. Qodarian Pramukanto, MSi. selaku dosen penguji yang telah memberikan masukan untuk perbaikan skripsi ini.

3. Prof. Dr. Ir. Wahyu Mugnisjah, MAgr selaku dosen pembimbing akademik atas bimbingan yang telah diberikan selama masa kuliah.

4. Keluarga tercinta, Papa Zahari dan Mama Syafrida, Irfan Hidayat, Athiyyah Risqullah dan Keluaraga Besar yang telah memberikan bantuan baik moril maupun materiil, dorongan dan doa yang tulus.

5. Dudun, DN, yuni, rimot, cuprim, fidry, endah, M, yha, hafid, yang telah memberikan bantuan, semangat dan kebersamaan.

6. Staf Dinas Pertamanan dan Kebersihan Kota Pekanbaru dan Bappeda Kota Pekanbaru yang telah memberikan data selama pelaksanaan penelitian.

7. Keluarga besar lanskap 42 dan teman satu pembimbing skripsi (Lya, cindy, frans, farida) yang telah memberikan semangat dan bantuan selama pelaksanaan penelitian serta kebersamaan yang indah.

8. Keluarga Wisma Bintang (Hanum, rena, uti, nira, lina, eny, reikha, meri, gamma, vika, siska, ari) atas bantuan, semangat dan kebersamaan yang indah.

9. Pelangi untuk inspirasi dan semangat 
10. Serta pihak-pihak dan rekan mahasiswa lain yang tidak dapat penulis sebutkan satu per satu, atas segala bantuannya.

Semoga penelitian ini berguna bagi yang memerlukan.

Bogor, September 2009

Penulis 


\section{DAFTAR ISI}

Halaman

DAFTAR TABEL ....................................................................... ix

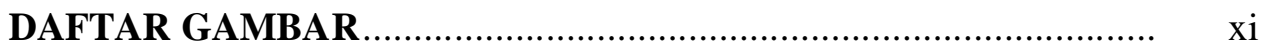

DAFTAR LAMPIRAN …............................................................... xiii

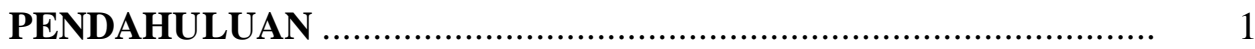

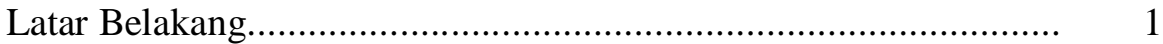

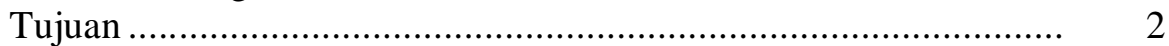

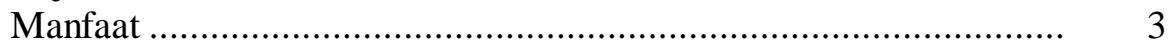

Kerangka pemikiran ......................................................... 3

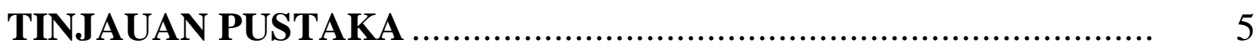

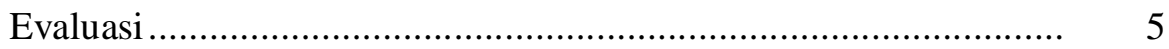

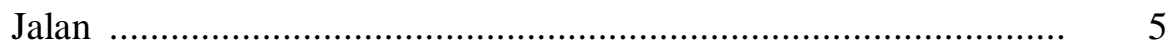

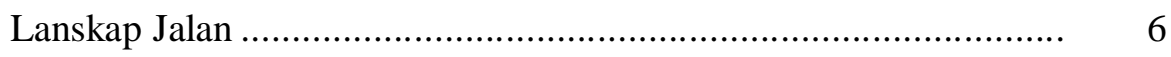

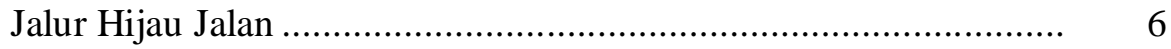

Tanaman Jalur Hijau Jalan .................................................... 7

Tata Hijau Jalur Hijau Jalan .................................................. 8

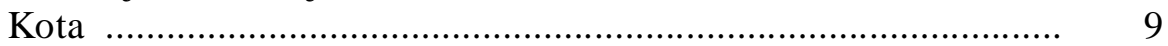

Fungsi Tanaman Lanskap Jalan.............................................. $\quad 10$

Estetika Tanaman Lanskap Jalan ................................................ 11

Pengelolaan Tanaman Lanskap Jalan ......................................... 13

METODOLOGI................................................................ 16

Tempat dan Waktu Penelitian ..................................................... 16

Metode Penelitian ............................................................. 16

HASIL DAN PEMBAHASAN .................................................. 26

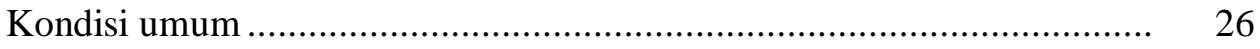

Letak Geografis ........................................................... 26

Geologi, Tanah, Topografi ................................................... 26

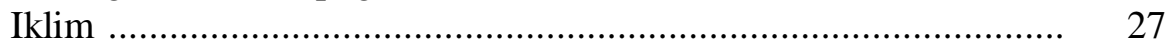

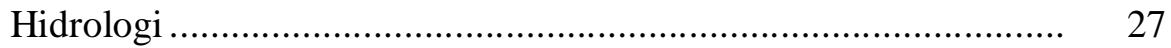

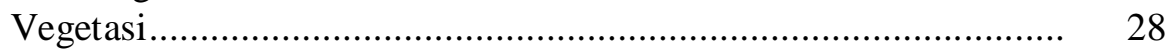

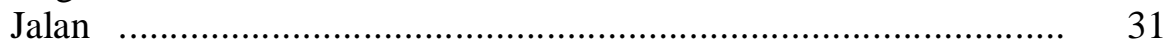

Elemen Pembentuk Tapak ....................................................... 39

Disain Penanaman ................................................................ 41

Tata Guna Lahan .............................................................. 45

Sosial Ekonomi.................................................................... 45

Pengelolaan Jalur Hijau ...................................................... 45

Penilaian Aspek Fungsi Tanaman ................................................ 48

Fungsi Pengarah ......................................................... 48

Fungsi Pembatas Visual ......................................................... 54

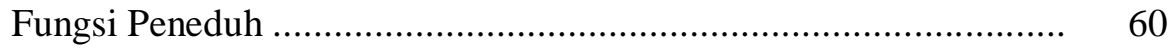

Fungsi Kontrol Cahaya ............................................................. 65

Fungsi Kontrol Bunyi ....................................................... $\quad 70$ 
Fungsi Kontrol Polusi ................................................................. $\quad 75$

Fungsi Pemberi Identitas.............................................................. 81

Peneilaian Seluruh Aspek Fungsi Tanaman Lanskap Jalan Pada

Setiap Segmen Jalan .................................................................... 85

Penilaian Kualitas Estetika Tanaman..................................................... 87

Nilai SBE Tata Hijau Sesuai Kategori Penyusunan Tanaman.......... 87

Pengelompokan Keindahan Lanskap Pada Tata Hijau Lanskap

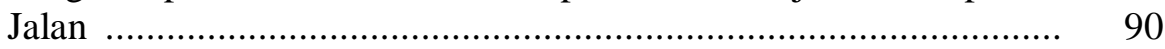

Lanskap Pohon Massal Sejenis ………………………………...... 91

Lanskap Pohon Kelompok Campuran ............................................ 96

Lanskap Massal Campuran .......................................................... 100

Penilaian Aspek Pengelolaan Tanaman .................................................. 106

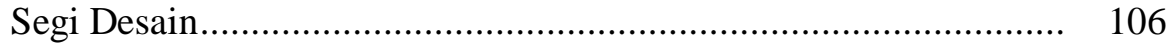

Segi Teknik ...................................................................... 111

Lanskap Massal Campuran ......................................................... 117

Gabungan Nilai Aspek Fungsional, Estetika dan Pengelolaan .................. 119

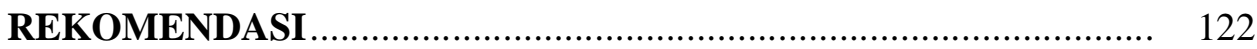

Aspek Fungsi .................................................................... 122

Aspek Estetika ........................................................................ 123

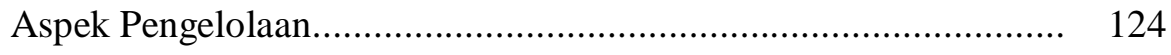

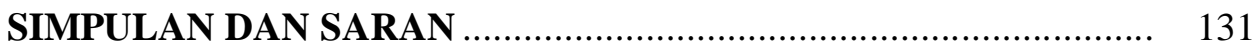

DAFTAR PUSTAKA ………………………………………….... 133

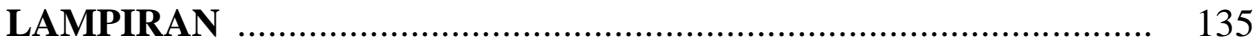




\section{DAFTAR TABEL \\ Teks}

Nomor

Halaman

1. Jenis, Bentuk, dan Sumber Data ...................................................... 16

2. Kriteria Penilaian Fungsi Tanaman ................................................. 19

3. Kriteria Penilaian Pengelolaan Tanaman ............................................ 22

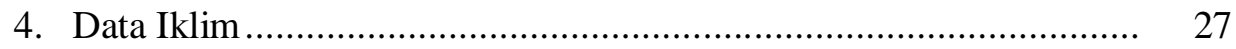

5. Karakteristik Pohon pada Lokasi Penelitian........................................ 29

6. Kondisi Jalan Penelitian............................................................... 32

7. Jenis Tanaman Pada Lokasi Penelitian ............................................. 39

8. Elemen Penunjang Pada Lokasi Penelitian $\quad$..................................... 41

9. Pembagian Segmen Jalan, Lokasi, dan Komposisi Tanaman ............ 43

10. Fasilitas dan Aktifitas Ekonomi....................................................... 45

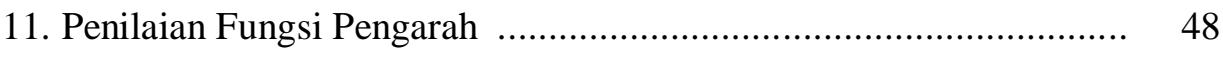

12. Penilaian Fungsi Pembatas Visual ................................................. 54

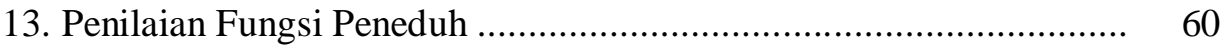

14. Penilaian Fungsi Kontrol Cahaya ………………………………..... 65

15. Penilaian Fungsi Kontrol Bunyi ........................................................ 70

16. Penilaian Fungsi Kontrol Polusi ........................................................ 75

17. Penilaian Fungsi Pemberi Identitas ................................................... 81

18. Penilaian Seluruh Aspek Fungsi Tanaman Lanskap Jalan................. 83

19. Pengelompokan Keindahan Lanskap …………………………....... $\quad 90$

20. Pengelompokan Keindahan pada Tiap Segmen ……….................... $\quad 90$

21. Karakeristik Lanskap Pohon Massal Sejenis dengan Keindahan Pemandangan Tinggi.................................................................. 91

22. Karakeristik Lanskap Pohon Massal Sejenis dengan Keindahan Pemandangan Sedang .................................................. 93

23. Karakeristik Lanskap Pohon Massal Sejenis dengan Keindahan Pemandangan Rendah .......................................................... 95

24. Karakeristik lanskap Pohon Kelompok Campuran dengan Keindahan Pemandangan Tinggi ................................................ 96

25. Karakeristik Lanskap Pohon Kelompok Campuran dengan Keindahan Pemandangan Sedang. 
26. Karakeristik Lanskap Pohon Kelompok Campuran dengan

Keindahan Pemandangan Rendah

27. Karakeristik Lanskap Massal Campuran dengan Keindahan Pemandangan Tinggi. 100

28. Karakeristik Lanskap Massal Campuran dengan Keindahan Pemandangan Sedang 102

29. Karakeristik Lanskap Massal Campuran dengan Keindahan Pemandangan Rendah 104

30. Penilaian Pengelolaan Segi Desain 106

31. Penilaian Pengelolaan Segi Teknik. 112

32. Penilaian Seluruh Aspek Pengelolaan Tanaman 112

33.Gabungan Nilai Aspek Fungsional, Estetika, dan Pengelolaan 120

34. Kegiatan pemeliharaan pasca panen dan rutin 125

35. Rekomendasi Penataan Tanaman 126

36. Rekomendasi Aspek Fungsi Tanaman Lanskap Jalan 127

37. Rekomendasi Aspek Estetika Tanaman Lanskap Jalan . 129

38. Rekomendasi Aspek Pengelolaan Tanaman Lanskap Jalan. 130 


\section{DAFTAR GAMBAR}

\section{Teks}

Nomor

Halaman

1. Kerangka Pemikiran Penelitian ....................................................... 4

2. Penanaman Tanaman Berlapis Sebagai Pembatas Pandangan ........... 11

3. Variasi Tinggi Tanaman Dalam Mengurangi silau Cahaya .............. 11

4. Penanaman Tanaman Berlapis Lebih Efektif Mengontrol Cahaya.... 11

5. Bentuk-bentuk Arsitektural Tajuk Pohon......................................... 12

6. Peta Lokasi Penelitian .................................................................... 18

7. Sudut Pengambilan Gambar .......................................................... 21

8. Tahapan Penelitian ................................................................... 25

9. Dimensi Jalan Cutn Nyak Dien ................................................. 32

10. Dimensi Jalan Cut Nyak Dien (dengan median)............................. 32

11. Dimensi Jalan Gajah Mada......................................................... 33

12. Dimensi Jalan Sudirman.............................................................. 33

13. Dimensi Jalan Pangeran Diponegoro ………………………......... 33

14. Segmen Jalan Cut Nyak Dien ..................................................... 34

15. Segmen Jalan Sudirman 1 ........................................................ 35

16. Segmen Jalan Sudirman 2 ……………………….................. 36

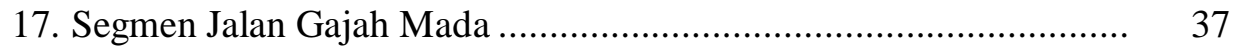

18. Segmen Jalan Diponegoro ………………………..................... 38

19. Deretan Tanjung Sebagai Fungsi Pengarah di Jalan Cut Nyak

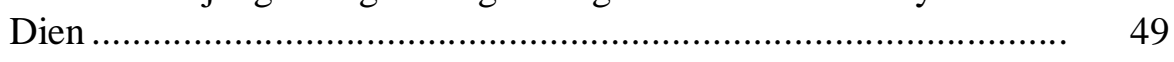

20. Deretan Pohon Ditanam Rapat Menjadi Pembatas Visual ke Arah Hutan Kota di Jalan Diponegoro..................................................... 59

21. Deretan Pohon Angsana dan Mahoni Sebagai Fungsi Peneduh di Jalan Sudirman................................................................... 64

22. Deretan Pohon Mahoni di Sepanjang Jalan Sudirman Sebagai Fungsi Kontrol Cahaya ................................................................. 68

23. Deretan Mahoni Kombinasi dengan Cemara dan Perdu sebagai Kontrol Bunyi di Kantor Gubernur Jalan Cut Nyak Dien............................. 73

24. Pohon Massal Campuran Kombinasi dengan Perdu Sebagai Fungsi Kontrol Polusi di Jalan Sudirman .................................................... $\quad 79$

25. Deretan Pohon Angsana Menjadi Identitas Pada Jalan Sudirman..... 84 
26. Lanskap Nilai SBE Terendah Pohon massal Sejenis (a), Pohon Kelompok Campuran (b), Massal Campuran (c)........................... 87

27. Lanskap Nilai Tertinggi Pohon Massal Sejenis, Pohon Kelompok Campuran, Massal Campuran.............................................................. 88

28. Grafik nilai SBE Pohon Massal Sejenis ....................................... 89

29. Grafik Nilai SBE Pohon Kelompok Campuran .............................. 86

30. Grafik Nilai SBE Massal Campuran ............................................ 86

31. Lanskap keindahan pemandangan tinggi pohon massal sejenis pada Jl. Diponegoro (a) dan Jl. Sudirman (b, c, dan d ............................ 93

32. Lanskap keindahan pemandangan tinggi pohon massal sejenis pada J1. Diponegoro (a) dan J1. Sudirman (b, c, dan d) .............................

33. Lanskap keindahan pemandangan rendah pohon massal sejenis pada J1. Cut Nyak Dien (a) dan Jl. Diponegoro ( b)

34. Lanskap keindahan pemandangan tinggi pohon kelompok campuran pada Jl.Sudirman (a dan b)

35. Lanskap keindahan pemandangan sedang pohon kelompok campuran pada Jl.Diponegoro (a) dan Jl. Sudirman (b).....

36. Lanskap keindahan pemandangan sedang pohon kelompok campuran pada Jl. Cut Nyak Dien (a dan b)

37. Lanskap keindahan pemandangan tinggi massal campuran pada J1. Diponegoro (a), Jl. Sudirman (b dan c), dan Jl. gajah mada (d)........

38. Lanskap keindahan pemandangan sedang massal campuran pada Jl. Cut Nyak Dien (a), Jl. Diponegoro (b), dan Jl. Sudirman (c dan d).

39. Lanskap keindahan pemandangan rendah massal campuran pada Jl. Cut Nyak Dien (a) dan Jl. Sudirman (b, c, dan d)

40. Desain Penanaman Pada Jalan Cut Nyak Dien Membutuhkan Pemeliharaan Intensif

41. Desain Penanaman Pada Jalan Gajah Mada Membutuhkan Pemeliharaan Intensif

42. Keadaan Median Jalan Kurang Penyulaman .....

43. Kegiatan Pemeliharaan Jalur Hijau di Jalan Sudirman 


\section{DAFTAR LAMPIRAN}

\section{Teks}

Nomor

1. Kuesioner Penilaian Estetika .................................................. 136

2. Tanaman Lanskap yang Berpotensi Tinggi Menyerap Polutan Gas

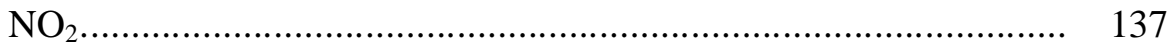

3. Pengolahan Nilai SBE …................................................. 140

4. Pengelompokan Keindahan ....................................................... 145

5. Foto-foto Lanskap pada Evaluasi Estetika .................................... 146 


\section{PENDAHULUAN}

\section{Latar Belakang}

Jalan merupakan jalur sirkulasi penting di Indonesia yang menjadi jalur penghubung suatu daerah ke daerah lainnya. Perkembangan suatu kota diikuti dengan perkembangan jalur sirkulasinya. Pembangunan fisik seperti jalan perlu diimbangi dengan pembangunan tata hijaunya. Kota Pekanbaru merupakan kota yang sedang berkembang. Perkembangan Kota Pekanbaru membutuhkan sarana jalan yang baik untuk mendukung kelancaran lalu lintas. Pada tahun 2007 panjang jalan di Kota Pekanbaru 2.573,34 km (Sumber : Bappeda Kota Pekanbaru) dengan luas taman di Kota Pekanbaru menurut Dinas Kebersihan dan Pertamanan Kota Pekanbaru adalah 27,12 ha termasuk di dalamnya jalur hijau jalan.

Jalan-jalan utama di Pekanbaru umumnya memiliki median dan bahu jalan yang dijadikan sebagai jalur hijau jalan. Jalur hijau jalan berupa median dan bahu jalan yang ditanami pohon dengan kombinasi semak dan grouncover. Kombinasi ini memberikan nilai keindahan bagi pengguna jalan. Pohon merupakan elemen pembentuk lanskap utama yang ditemukan sepanjang jalan di Pekanbaru. Pohonpohon di sepanjang jalan Kota Pekanbaru merupakan pohon-pohon tua yang rindang. Mayoritas pohon yang dapat ditemui di sepanjang jalan Kota Pekanbaru yaitu pohon angsana, mahoni dan tanjung. Pohon-pohon ini memberikan kenyamanan bagi pengguna jalan. Jumlah pohon penghijauan yang telah terdata pada Dinas Kebersihan dan Pertamanan Kota Pekanbaru adalah 20.460 buah pohon.

Pembangunan jalan sering melupakan penataan jalur hijau jalan. Jalur hijau jalan merupakan bagian dari ruang terbuka hijau yang digunakan untuk menjaga keseimbangan lingkungan. Tanaman merupakan elemen utama dalam penataan jalur hijau jalan. Fungsi tanaman dalam lanskap jalan adalah untuk mengurangi cahaya silau matahari dan kendaraan, sebagai pengarah, pembatas fisik, mengendalikan pergerakan, mengontrol iklim mikro, dan habitat satwa (Carpenter et al., 1975). Tanaman pada jalur hijau jalan memberikan kenyamanan dan keindahan serta dapat membentuk karakter suatu kota. Menurut Simonds (1983), lanskap jalan adalah wajah dari karakter lahan atau tapak yang terbentuk 
pada lingkungan jalan, baik yang terbentuk dari elemen lanskap alamiah seperti bentuk topografi lahan yang mempunyai panorama indah, maupun yang terbentuk dari lemen lanskap buatan manusia yang disesuaikan dengan kondisi lahannya. Tata susunan tanaman seperti pohon, semak, dan groundcover yang sesuai dengan prinsip desain akan memberikan tampilan visual yang indah. Penanaman jalur hijau jalan adalah berdasarkan pada fungsi tanpa melupakan keindahannya (Simonds, 1983). Keindahan lanskap jalan juga dapat terbentuk dari bentuk arsitektural tajuk pohon. Penataan tanaman pada lanskap jalan diperlukan untuk memperindah kota. Penataan tanaman yang baik harus didukung oleh pengelolaan yang baik pula. Pengelolaan yang baik harus dilakukan oleh Dinas Kebersihan dan Pertamanan Kota Pekanbaru. Pengelolaan penting untuk mempertahankan nilai fungsional dan estetika penataan tanaman.

Studi evaluasi mengenai nilai fungsional dan estetika lanskap jalan diperlukan untuk mengetahui kontribusi positif yang diberikan tanaman di sepanjang jalur hijau jalan. Evaluasi tata hijau jalan Kota Pekanbaru perlu dilakukan untuk mengetahui sejauh mana tata hijau jalur hijau jalan Kota Pekanbaru dapat memenuhi fungsi utamanya. Evaluasi juga diperlukan dalam pengembangan lanskap jalan dan mempertahankan keberadan pohon-pohon tua. Kedua nilai ini dapat menjadi tolak ukur lanskap jalan kota dan karakter yang terbentuk dari suatu lanskap jalan kota. Pendekatan yang dilakukan untuk mengetahui nilai fungsional, estetika dan pengelolaan dengan cara observasi langsung, tinjauan pustaka dan kuesioner. Pendugaan keindahan lanskap dengan evaluasi kualitas visual lanskap melibatkan sejumlah responden (Daniel \& Boster, 1976). Studi evaluasi nilai fungsional, estetika dan pengelolaan ini dapat digunakan sebagai bahan pertimbangan dalam perencanaan, perancangan dan pengelolaan tanaman pada lanskap jalan agar terbentuk suatu jalur hijau jalan yang fungsional, memberikan kualitas visual yang estetis dan berkelanjutan.

\section{Tujuan Penelitian}

Penelitian nilai fungsional, estetika dan pengelolaan bertujuan untuk :

1. Mengetahui nilai fungsional, estetika dan pengelolaan tanaman pada lanskap jalan Kota Pekanbaru. 
2. Menganalisis nilai fungsional, estetika dan pengelolaan tatanan tanaman pada jalur hijau jalan sesuai kriteria penilaian fungsional, estetika dan pengelolaan jalur hijau yang baik dalam ilmu Arsitektur Lanskap.

3. Merumuskan rekomendasi dalam usaha peningkatan nilai fungsional, estetika dan pengelolaan tanaman lanskap jalan Kota Pekanbaru.

\section{Manfaat Penelitian}

Manfaat dari penelitian ini yaitu :

1. Memberikan informasi nilai fungsional dan estetika yang terbentuk dari penataan tanaman dan pengelolaan tanaman lanskap jalan Kota Pekanbaru.

2. Bahan pertimbangan bagi arsitek lanskap, perencana dan pengelola dalam mengembangkan lanskap jalan untuk melihat aspek nilai visual estetika.

3. Rekomendasi bagi pihak-pihak terkait dalam pengembangan dan pelestarian jalur hijau jalan Kota Pekanbaru.

\section{Kerangka Pemikiran}

Evaluasi dilakukan pada penataan tanaman di jalur hijau jalan diperlukan untuk mengetahui efektivitas keberadaan tanaman dalam segi fungsi, estetika dan efektivitas pengelolaannya, dan juga mengoptimalkan keberadaan tanaman pada jalur hijau jalan. Evaluasi tata hijau lanskap jalan Kota Pekanbaru didasarkan pada penataan tanaman untuk memenuhi fungsi utama dan estetika bagi pengguna jalan serta pengelolaan jalur hijau jalan. pengamatan dan penelitian perlu dilakukan terhadap tiga aspek yaitu fungsional, estetika dan pengelolaan tata hijau jalan. Hasil penilaian fungsi dan pengelolaan akan dikelompokkan kedalam kategori sangat baik, baik, sedang, dan buruk dan keindahan tinggi, sedang, dan rendah untuk nilai estetika dan dianalisis. Analisis nilai fungsional dan pengelolaan tanaman didasarkan pada kriteria penilaian pada bidang Arsitektur lanskap dan nilai estetika berdasarkan pada penilaian SBE. Hasil dari analisis digunakan untuk menyusun hasil akhir berupa rumusan rekomendasi penataan tanaman lanskap jalan yang fungsional juga estetis dan berkelanjutan (Gambar 1). 


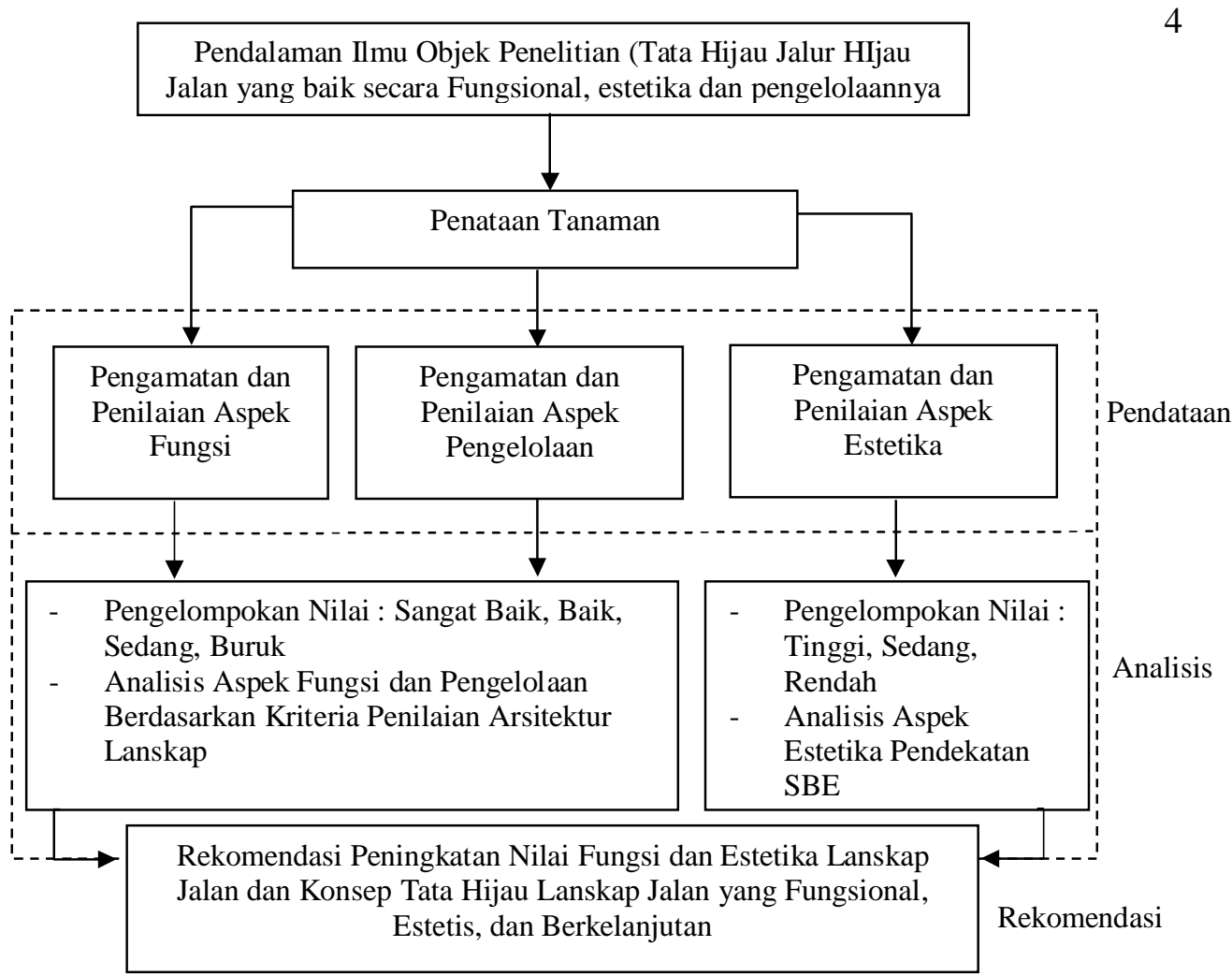

Gambar 1. Kerangka Pikir Penelitian 


\title{
TINJAUAN PUSTAKA
}

\begin{abstract}
Evaluasi
Evaluasi adalah kegiatan menilai, menaksir dan mengkaji. Evaluasi adalah menentukan nilainya. Evaluasi bertujuan untuk penyeleksian dan menampilkan informasi yang diperlukan dalam mendukung pengambilan kesimpulan dan keputusan tentang suatu program serta nilainya (Echols dan Shadily, 1996). Evaluasi bertujuan untuk melihat apakah sesuatu yang telah dilakukan dapat dilanjutkan (memberikan hasil positif) dan cara pengembangannya.
\end{abstract}

\section{Jalan}

Jalan adalah tempat perpindahan manusia dan barang dari satu tempat ke tempat lainnya. Jalan merupakan suatu kesatuan sistem jaringan jalan yang mengikat dan menghubungkan pusat-pusat pertumbuhan dengan wilayah yang berada dalam pengaruh pelayanannya dalam satu hubungan hirarki (Direktorat Bina Marga, 1996).

Lanskap kehidupan manusia tersusun atas jalan dan tempat, dimana jalan berfungsi sebagai jalur pergerakan orang dan kenderaan serta tempat sebagai pusat aktivitas dimana orang bekerja, berdagang, belajar, beribadah dan bersantai (Simonds, 1983). Jalan sebagai jalur pergerakan merupakan suatu kesatuan secara keseluruhan, seharusnya bersifat lengkap, aman, efisien serta dapat berfungsi sebagai jalur sirkulasi dan penghubung. Jalan dibagi tiga bagian berdasarkan peruntukkannya yaitu sirkulasi kenderaan bermotor, sirkulasi sepeda, dan sirkulasi pejalan kaki. Pembagian jalan menurut Undang-Undang No. 13 Tahun 1980 dan Peraturan Pemerintah No. 26 tahun 1985 :

1. Daerah Manfaat Jalan (DMJ) yang meliputi badan jalan, saluran tepi jalan, beserta ambang pengamannya:

a. Badan jalan, yaitu jalur lalu lintas dengan atau tanpa median

b. Ambang pengaman, yaitu bagian yang terletak paling luar dari DMJ yang berfungsi mengamankan bangunan jalan. 
2. Daerah Milik Jalan (Damija) yang meliputi Daerah Manfaat Jalan dan sejalur tanah tertentu di luar DMJ yang berfungsi mengamankan bangunan jalan.

3. Daerah Pengawasan Jalan (Dawasja) yang merupakan sejalur tanah tertentu di luar DMJ yang diawasi Pembina jalan agar tidak menganggu pandangan pengemudi dan kostruksi jalan.

Menurut Haris dan Dines (1988), jalan dikelompokkan berdasarkan peranannya:

1. Jalan arteri, yaitu jalan yang melayani angkutan utama dengan ciri-ciri perjalanan jauh, kecepatan rata-rata tinggi, volume satuan angkutan rata-rata besar, dan jalan masuk dibatasi secara efisien.

2. Jalan kolektor, yaitu jalan yang melayani angkutan pengumpulan atau pembagian ciri-ciri perjalanan jarak sedang dengan volume satuan angkutan dan kecepatan rata-rata sedang, serta jumlah kenderaan masuk dibatasi.

3. Jalan lokal, yaitu jalan yang melayani angkutan setempat dengan ciri-ciri perjalanan jarak pendek dengan kecepatan rata-rata rendah dan volume satuan angkutan rata-rata kecil, serta jumlah jalan masuk dibatasi.

\section{Lanskap Jalan}

Lanskap jalan merupakan wajah dan karakter lahan atau tapak yang terbentuk pada lingkungan jalan, baik elemen lanskap alami seperti bentuk topografi yang mempunyai panorama indah maupun terbentuk dari lanskap buatan manusia yang disesuaikan dengan kondisi lahannya (Simonds, 1983). Lanskap jalan ini mempunyai ciri khas karena harus disesuaikan dengan ketentuan geometrik jalan dan diperuntukkan terutama bagi kenyamanan pemakai jalan serta diusahakan untuk menciptakan lingkungan jalan yang indah, serasi, dan memenuhi fungsi keamanan (Direktorat Bina Marga, 1996).

Suatu perencanaan lanskap jalan harus memberi kesan yang menyenangkan dan setiap pergerakan akan berguna bagi pemakai bila terdapat keharmonisan dan kesatuan dengan karakteristik lanskap yang ada dan menghasilkan secara fisik fungsional dan secara visual estetika (Simonds, 1983).

\section{Jalur Hijau Jalan}


Jalur hijau jalan merupakan tempat/lahan/ bagian dari jalan sebagai tempat penanaman tanaman. Bagian dari jalan yang digunakan sebagai jalur hijau jalan yaitu median jalan, sepanjang trotoar, dan bahu jalan. Jalur hijau jalan ini dapat terletak di dalam Daerah milik Jalan (Damija) dan dalam Daerah Pengawasan Jalan (Dawasja).

Berdasarkan letak penanamannya jalur hijau dibedakan menjadi empat yaitu : tanaman tepi jalan, median jalan, daerah tikungan, dan persimpangan dan daerah berterrain (Direktorat Jendral Bina Marga, 1996). Daerah tepi jalan berfungsi sebagai daerah untuk keselamatan dan kenyamanan pemakai jalan, lahan untuk pengembangan jalan, kawasan penyangga, jalur hijau, tempat pembangunan fasilitas pelayanan dan melindungi bentukan alam. Median jalan adalah jalan yang memisahkan dua jalan yang berlawanan, dapat digunakan sebagai pendukung keselamatan pengendara, peletakkan rambu-rambu lalu lintas, ataupun sebagai jalur hijau dengan persyaratan tertentu.

Penanaman jalur hijau jalan di sepanjang berm dan median jalan yang bersifat sederhana dalam penataannya harus berpedoman pada kebutuhan, kecocokan penampilan di tiap musim penampilan di tiap tahapan pertumbuhan, kecocokan antara tanaman dan bangunan serta lingkungan sekitar dan keefisienan dalam pemeliharaan (Simonds, 1983).

\section{Tanaman Jalur Hijau Jalan}

Tanaman jalan ialah tanaman yang digunakan di dalam perencanaan lanskap jalan, yang mempunyai sistem perakaran yang tidak merusak konstruksi jalan, percabangan tanaman tidak mudah patah dan mudah dalam pemeliharaannya (Direktorat Bina Marga, 1996).

Tanaman tepi jalan adalah untuk membedakan area melalui kualitas lanskap yang unik melapis jalur lalu lintas, dan memperkuat jajaran park, memberikan penekanan pada node, sebagai peneduh dan daya tarik, screen atas menutupi pemandangan tidak menarik, menghilangkan kesilauan, serta mengurangi polusi udara dan polusi suara (Simonds, 1983).

Tanaman yang terdapat pada jalur hijau jalan dapat digolongkan menjadi: 
1. Pohon, berfungsi sebagai pengarah dan pengaman jalan, dapat menutupi pemandangan yang kurang baik, penghalang sinar matahari dan angin, sebagai identitas wilayah, mempertegas ruang, dapat menyediakan cadangan air tanah, pengatur iklim mikro, dan mampu memberi kesan psikologis kepada pengguna jalan.

2. Semak/perdu, berfungsi sebagai pembatas visual, memberikan nilai estetika, menahan sinar lampu kenderaan, sebagai penahan kecelakaan dan pembatas jalur median.

3. Penutup tanah/rumput, berfungsi sebagai penahan air hujan supaya tidak mengalir langsung ke jalan bebas hambatan.

Menurut Direktorat Bina Marga (1996), persyaratan utama yang perlu diperhatikan dalam memilih jenis tanaman lanskap jalan antara lain adalah:

1. Perakaran tidak merusak konstruksi jalan

2. Mudah dalam perawatan

3. Batang/cabang tidak mudah patah

4. Daun tidak mudah rontok/gugur

Prinsip yang perlu diperhatikan dalam merancang penanaman adalah kesederhanaan, skala, proporsi, keseimbangan, irama, kontras dan kesatuan yang dapat memberikan nilai keindahan dan menambah kualitas lingkungan (Carpenter et al., 1975 ).

\section{Tata Hijau Jalur Hijau Jalan}

Tata hijau merupakan peletakan, penanaman, susunan tanaman pada tapak. Tata hijau yang baik dapat memberikan manfaat dan visual yang baik. Pedoman umum dalam mengkomposisikan tanaman lanskap jalan untuk memberi kesan estetika yang menarik yaitu: 1) tanaman dapat disajikan secara massal, 2) disusun secara berkesinambungan dan linier di sepanjang jalan, 3) menggunakan berbagai variasi bentuk tajuk, warna, dan tekstur daun, 4) kombinasi antara semak dan 
pohon, 5) memberi focal point atau kontras, 6) menggunakan display tanaman khusus pada tempat-tempat tertentu.

Penataan tanaman di sepanjang jalan secara horizontal ditanam kontinyu dan berbentuk linear, secara vertical tinggi tanaman divariasikan untuk menciptakan keragaman suasana. Pemberian tanaman kontras seperti warna, ukuran dan tekstur tanaman diperlukan untuk menguranggi kemonotonan.

Median berfungsi sebagai rintangan atau penuntun arah untuk mencegah tabrakan dengan kenderaan dari arah yang berlawanan dan mengurangi silau lampu kenderaan dengan menempatkan tanaman dengan kepadatan dan ketinggian yang tepat (Carpenter et al., 1975 ).

Penyusunan komposisi tanaman perlu memperhatikan bentuk, tinggi, tekstur dan warna dari bagian tanaman sehingga menciptakan keserasian secara menyeluruh (Stevens et al., 1994). Komposisi merupakan susunan unsur-unsur rupa yang menciptakan kesan, kesatuan, paduan irama, dan keseimbangan (Reid, 1993). Penyusunan komposisi tanaman diperlukan juga adanya kontras sehingga tercipta fokus, irama dan keseimbangan. Komposisi desain demikian akan terasa lebih hidup, tidak membosankan, dan dapat bertahan lama (Laurie, 1975).

Penyusunan komposisi tanaman harus serasi di antara unsur lain di sekitarnya. Perlu untuk mengetahui tentang macam-macam sifat tanaman yang diperlukan dalam merancang taman. Merancang lanskap dapat menciptakan pandangan yang menyenangkan (Carpenter et al., 1975). Tanaman menjadi elemen utama lanskap meliputi penutup tanah, semak/perdu, pohon dan lain-lain. Penggunaan elemen tanaman pada lanskap dikarenakan keindahan dari bagian tanaman dengan aneka bentuk, warna, tekstur, dan aroma dan kesan alami yang ditimbulkan (Carpenter et al, 1975).

\section{Kota}

Kota, menurut definisi universal, adalah sebuah area urban yang berbeda dari desa ataupun kampung berdasarkan ukurannya, kepadatan penduduk, kepentingan, atau status hukum. Dalam konteks administrasi pemerintahan di Indonesia, kota adalah pembagian wilayah administratif di Indonesia setelah provinsi, yang dipimpin oleh seorang walikota. Kabupaten maupun kota 
merupakan daerah otonom yang diberi wewenang mengatur dan mengurus urusan pemerintahannya sendiri. Dahulu di Indonesia istilah kota dikenal dengan Daerah Tingkat II Kotamadya. Sejak diberlakukannya Undang-undang Nomor 22 Tahun 1999 tentang Pemerintahan Daerah, istilah Daerah Tingkat II Kotamadya pun diganti dengan kota saja (Wikipedia, 2008).

\section{Fungsi Tanaman Lanskap Jalan}

Tanaman menyediakan sumber makanan dasar dan habitat bagi kehidupan semua mahluk hidup melalui keterlibatannya dalam jaring-jaring makanan, transpirasi, kontrol iklim, penyimpanan air, bangunan tanah, penguraian bahan organik serta produksinya (Simonds, 1983).

Tanaman pada lanskap jalan berfungsi antara lain : pembatas fisik, kontrol iklim, kontrol kebisingan, pengontrol air, pencegah erosi, penyaringan udara, kontrol visual, dan habitat satwa (Carpenter et al., 1975). Lanskap yang terbentang sepanjang jalan harus memberikan kesan yang menyenangkan dengan menyelaraskan keharmonisan dan kesatuan tanaman sehingga fungsional secara fisik dan visual (Simonds, 1983).

Menurut Booth (1983), vegetasi di lingkungan perkotaan dapat memenuhi tiga fungsi utama yaitu fungsi struktural, fungsi lingkungan dan fungsi visual. Fungsi struktural meliputi fungsi tanaman sebagai dinding, atap dan lantai dalam membentuk suat ruang serta mempengaruhi pemandangan dan arah pergerakan. Fungsi lingkungan meliputi peran tanaman dalam meningkatkan kualitas udara dan kualitas air, mencegah erosi serta peran tanaman dalam memodifikasi iklim. Fungsi visual merupakan peran tanaman sebagai titik yang dominan dan sebagai penghubung visual melalui karakteristik yang dimilikinya yaitu ukuran, bentuk, warna dan tekstur.

Menurut Laurie (1975), vegetasi sebagai unsur alamiah merupakan indikator iklim mikro yang baik seperti jalur pepohonan yang rimbun dapat mengalihkan hembusan angin, bayangan yang disebabkan oleh naungan pohon dapat mempengaruhi suhu dan oksigen yang diproduksi tanaman sebagai 
penyejuk. Tanaman di sepanjang jalur hijau jalan dapat menetralisir polusi yang berasal dari kenderaan bermotor.

Menurut Carpenter et al. (1975), Tanaman juga dapat berfungsilebih banyak daripada hanya pada keindahannya, tanaman dapat meningkatkan kualitas fungsional lingkungan. Tanaman dapat menjadi kontrol visual seperti pembatas pandangan (Gambar 2) dan mengurangi silau matahari dan cahaya lampu jalan

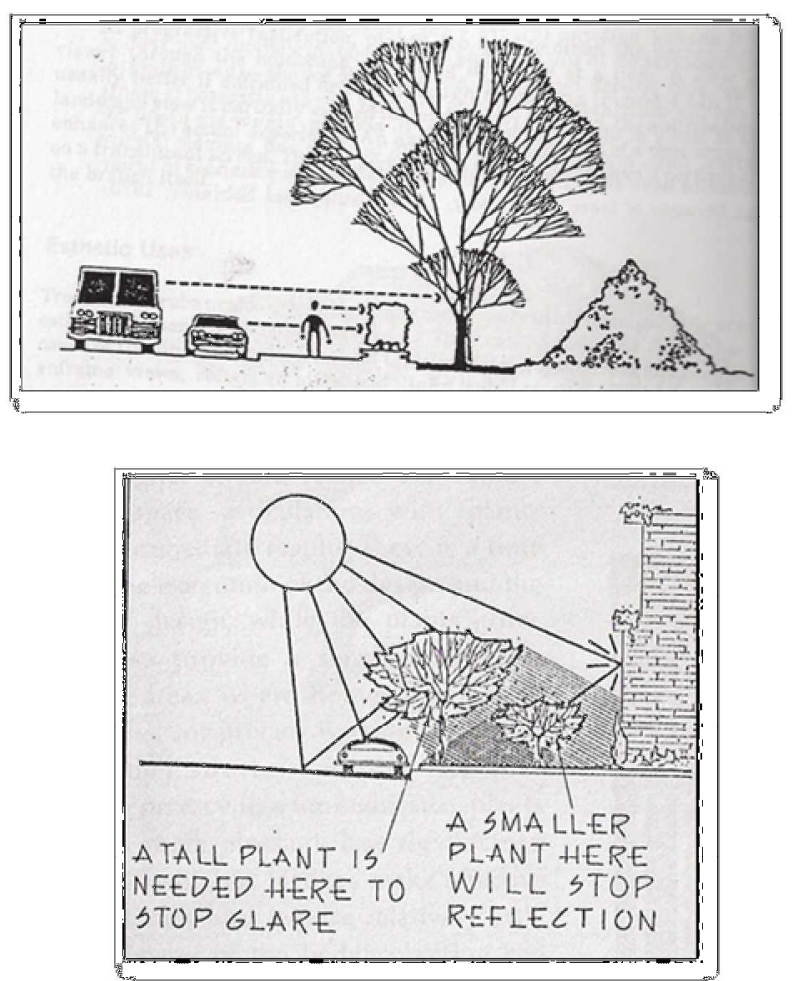

atau kendaraan (Gambar 3), dan dapat juga menjadi kontrol suara (Gambar 4).

Gambar 2. Penanaman Tanaman Berlapis Sebagai Pembatas Pandangan Gambar 3. Variasi Tinggi Tanaman Dalam Mengurangi Silau Cahaya

Gambar 4. Penanaman Tanaman Berlapis Lebih Efektif Mengontrol Suara

\section{Estetika Tanaman Lanskap Jalan}

Selain memperhatikan fungsi, penggunaan tanaman tepi jalan juga harus memperhatikan dari segi estetisnya yaitu bagian tanaman yang mempunyai

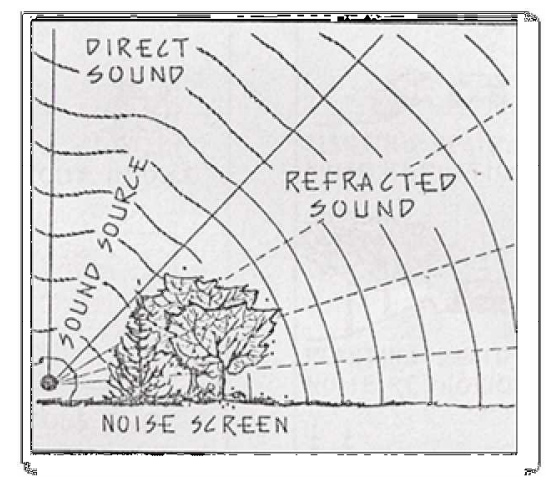


keunikan dan keindahan tersendiri baik ditinjau dari segi warna, aroma, tekstur, dan bentuk (Carpenter et al, 1975)

Secara umum di dalam lanskap, pohon merupakan elemen utama dan secara individu maupun berkelompok penampilan pohon dapat mempengaruhi penampakan visual dan memberikan kesan yang berbeda-beda dari jarak berbeda begi pengamat (Carpenter et al, 1975). Simonds

mengemukakan bagian terlihat dari bentuk tajuk bentuk tajuk yang memberikan kesan visual bentuk arsitektural pohon pohon yang paling nyata pohon. Pohon memiliki berbeda-beda dan yang berbeda pula. Bentukyang nampak dinyatakan

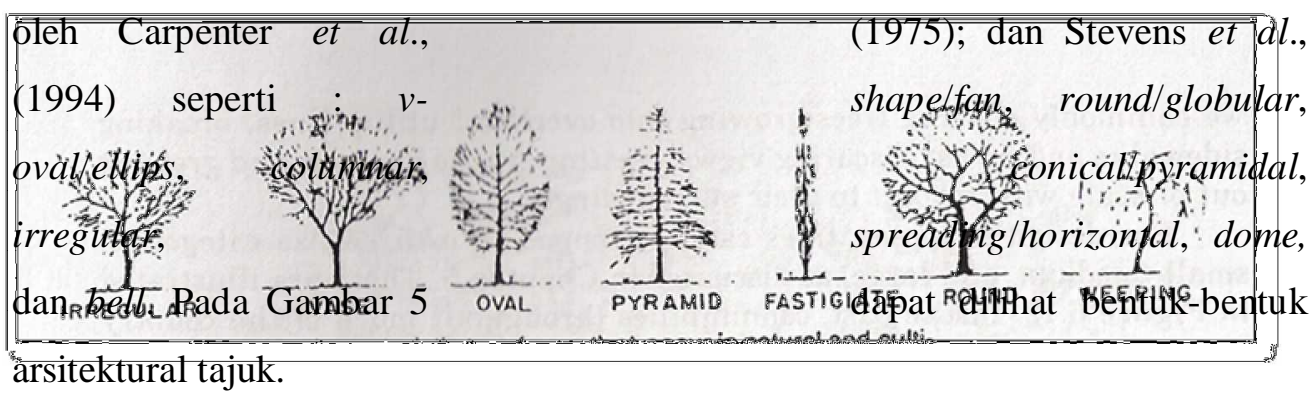
Gambar 5. Bentuk-bentuk Arsitektural

Tajuk Pohon

Sesuatu yang sebagai reaksi pengamat keharmonisan di antara (Simonds, 1983). Salah kualitas suatu lanskap secara visual dinilai indah karena mempunyai seluruh bagian-bagiannya satu cara untuk mengukur adalah menggunakan studi psikofisik yang menghubungkan persepsi manusia dengan lingkungannya (Daniel \& Boster, 1976).

Menurut Daniel dan Boster (1976), metode penilaian kualitas visual suatu ruang lanskap terdiri dari tiga kelompok, yaitu : inventarisasi deskriptif, survei dan kuesioner, dan evaluasi dari persepsi-persepsi. Salah satu cara mengevaluasi kualitas estetika suatu lanskap yang dikembangkan adalah Scenic Beauty Estimation (SBE). Metode SBE merupakan penilaian kuantitatif melalui evaluasi 
berdasarkan preferensi dengan menggunakan kuesioner untuk mengukur penilaian menurut rating berdasarkan kriteria pengamat. Makin tinggi preferensi, makin tinggi keindahannya (Daniel dan Booster, 1976).

\section{Pengelolaan Tanaman Lanskap Jalan}

Pengelolaan merupakan upaya manusia untuk mendayagunakan, memelihara dan melestarikan lanskap/lingkungan agar memperoleh manfaat yang maksimal dengan mengusahakan kontunyuitas kelestariannya (Arifin dan Arifin, 2000). Kegiatan yang dilakukan dalam pemeliharaan antara lain penyiraman, pendangiran dan penyiangan, pemangkasan, pemupukan, pencegahan dan pemberantasan hama/penyakit, penggantian tanaman/penyulaman.

Tingkat pemeliharaan dibagi menjadi tiga yaitu area membutuhkan pemeliharaan tinggi/intensif, sedang/semi-intensif, dan rendah/ekstensif (Carpenter et al, 1975). Semakin intensif suatu pemeliharaan maka biaya semakin tinggi.

Pemeliharaan dibagi menjadi dua, pemeliharaan ideal dan pemeliharaan fisik. Pemeliharaan ideal merupakan pemeliharaan yang mengacu pada tujuan dan desain semula, karenanya untuk tetap menjaga keindahan, keasrian, kenyamanan dan keamanan lanskap, pemeliharaan ideal tersebut perlu disertai dengan pemeliharaan fisik (Arifin dan Arifin, 2000). Pemeliharaan fisik meliputi pekerjaan untuk tetap menjaga keindahan, keasrian, kenyamanan, dan keamanan lanskap. Pekerjaan tersebut mencakup kegiatan pemeliharaan elemen keras seperti pembersihan terhadap lumut dan karat, pengecatan, dan penggantian atau perbaikan elemen yang rusak maupun kegiatan pemeliharaan tanaman seperti penyiraman tanaman, pembersihan, pendangiran, penyiangan gulma, pemangkasan, penyulaman, pemupukan, pengendalian hama dan penyakit serta pengangkutan sampah (Arifin dan Arifin, 2000).

Standar pemeliharaan/perawatan taman yaitu kondisi taman yang dipelihara/dirawat harus selalu kelihatan indah, rapi dan tampak bersih sepanjang hari berupa : rumput kelihatan rapi dan tampak hijau, tanaman kelihatan subur, 
terpangkas rapi dan segar, dan taman selalu terlihat bersih (Direktorat Bina Marga, 1996).

Carpenter et al. (1975) mengemukakan beberapa faktor penting dalam penyiraman yaitu :

1. Memberikan air yang cukup untuk merendam tanah pada kedalaman $15 \mathrm{~cm}$ atau lebih;

2. Memberikan air dengan kecepatan yang meminimalkan aliran permukaan;

3. Melakukan penyiraman yang rutin pada tanaman yang baru ditanam;

4. Tidak mengabaikan kebutuhan penguapan;

5. Tidak memberikan air yang berlebihan pada tanaman

Sulistyantara (2002) menjelaskan bahwa pemangkasan sangat berpengaruh terhadap kualitas pertumbuhan tanaman. Pemangkasan bertujuan untuk :

1. Memperbaiki lingkungan pertumbuhan tanaman, yaitu mengatur penerimaan sinar matahari, temperatur dan kelembaban.

2. Memelihara atau mengurangi ukuran tanaman sebagai upaya mencegah pertumbuhan tanaman yang tidak teratur mendapat bentuk baru yang sesuai dengan keragaman (desain)

3. Membuang cabang dan ranting yang rusak/mati dan mengganggu aktifitas

4. Merangsang pertumbuhan tunas bunga atau buah

Carpenter et al. (1975) mengemukakan bahwa pupuk bukan pengganti cahaya matahari dan air, tapi merupakan salah satu faktor lingkungan yang harus seimbang untuk menciptakan tanaman salah satu faktor lingkungan yang harus seimbang untuk menciptakan tanaman yang sangat potensial. Menurut Arifin (2000) metode atau cara pemupukan yang biasa dilakukan yaitu thumb methode, trenching methode (paritan), broadcast (menyebar), punch-bar methode tekanan udara. 
Arifin dan Arifin (2000) menjelaskan bahwa pengelolaan tanah yang baik dan dilakukan penggemburan dengan frekuensi tertentu, selain memberikan aerasi tanah yang baik juga dapat membunuh hama dan lundi-lundi yang ada di dalan tanah. Pengendalian terhadap gangguan hama yang efektif dapat dilakukan dengan cara mengenal jenis hama yang biasa menyerang tanaman taman. Pencegahan hama dapat dilakukan dengan menjaga lingkungan taman agar tetap bersih dan sehat. Lingkungan yang kotor, lembab, dan kurangnya sinar matahrai, sangat baik bagi pertumbuhan hama dan penyakit tanaman (Sulistyantara, 2002).

Menurut Arifin dan Arifin (2000) efektifitas pekerjaan pegawai pemeliharaan taman sangat ditentukan oleh; motivasi kerja dan ketrampilan pegawai; sistematika jadwal perencanaan pemeliharaan; ketersediaan alat dan bahan yang sesuai dengan kebutuhan; tingkat pengawasan kerja di lapang dan kelancaran komunikasi antara pimpinan dengan para mandor serta antara mandor dengan pegawai pemeliharaan taman di lapang. 


\section{METODOLOGI}

\section{Tempat dan Waktu}

Penelitian dilakukan pada 4 jalan di kota Pekanbaru. Jalan yang menjadi tempat penelitian antara lain : Jalan Sudirman, Jalan Diponegoro, Jalan Gajah Mada dan Jalan Cut Nyak Dien (Gambar 6). Penelitian dilakukan 4 bulan, yaitu pada bulan Maret sampai bulan Juni 2009. Pengumpulan data di lapang (Jalan Kota Pekanbaru) dilakukan selama 1 bulan yaitu pada bulan Maret sampai April dan dilanjutkan dengan pengumpulan data melalui kuesioner yang dilakukan di IPB pada bulan Mei sampai Juni. Lalu dilanjutkan dengan pengolahan data dan penulisan.

\section{Metode Penelitian}

Metode yang digunakan dalam penelitian ini adalah metode survey lapang terhadap penataan tanaman lanskap jalan kota pekanbaru. Ada 3 yang akan dilakukan dalam evaluasi ini yaitu: nilai fungsional, nilai estetika, dan pengelolaan. Penelitian akan dilakukan dalam beberapa tahapan yaitu: inventarisasi, analisis, dan sintesis.

\section{A. Inventarisasi}

Inventarisasi dilakukan untuk mengumpulkan data fisik dan non-fisik. Data primer didapatkan dari observasi lapang, pengukuran, pemotretan, kalkulasi, kuesioner dan wawancara. Data sekunder didapatkan dari studi pustaka, sumber yang terkait (Kantor Pemerintahan). Jenis, bentuk dan sumber data yang akan dikumpulkan dapat dilihat pada Tabel 1.

Tabel 1. Jenis, Bentuk dan Sumber Data

\begin{tabular}{|l|l|l|l|l|}
\hline No & \multicolumn{1}{|c|}{ Jenis Data } & \multicolumn{1}{|c|}{ Parameter } & Bentuk Data & Sumber Data \\
\hline 1. & Letak Geografis & $\begin{array}{l}\text { Batas wilayah, luas wilayah, } \\
\text { ketinggian tempat }\end{array}$ & Sekunder & $\begin{array}{l}\text { Pemerintah } \\
\text { kota, pustaka }\end{array}$ \\
\hline 2. & $\begin{array}{l}\text { Geologi, Tanah, } \\
\text { dan Topografi }\end{array}$ & $\begin{array}{l}\text { Struktur geologi, klasifikasi } \\
\text { tanah, topografi }\end{array}$ & Sekunder & $\begin{array}{l}\text { Pemerintah } \\
\text { kota, pustaka }\end{array}$ \\
\hline 3 & Iklim & $\begin{array}{l}\text { Suhu udara, kelembaban udara, } \\
\text { curah hujan }\end{array}$ & Sekunder & $\begin{array}{l}\text { Pemerintah } \\
\text { kota, pustaka }\end{array}$ \\
\hline 4 & Hidrologi & Sungai, air tanah & Sekunder & $\begin{array}{l}\text { Pemerintah } \\
\text { kota, pustaka }\end{array}$ \\
\hline 5 & Tata Guna Lahan & Pola penggunaan lahan & $\begin{array}{l}\text { Sekunder- } \\
\text { primer }\end{array}$ & $\begin{array}{l}\text { Pemerintah } \\
\text { kota, pustaka, } \\
\text { lapang }\end{array}$ \\
\hline
\end{tabular}


Tabel 1. (Lanjutan)

\begin{tabular}{|l|l|l|l|l|}
\hline No & \multicolumn{1}{|c|}{ Jenis Data } & \multicolumn{1}{|c|}{ Parameter } & Bentuk Data & Sumber Data \\
\hline 6 & Sosial Ekonomi & Aktifitas, fasilitas & $\begin{array}{l}\text { Sekunder- } \\
\text { primer }\end{array}$ & $\begin{array}{l}\text { Pemerintah } \\
\text { kota, lapang }\end{array}$ \\
\hline 7 & Jalan & $\begin{array}{l}\text { Lokasi dan dimensi jalan, elemen } \\
\text { pembentuk tapak, disain } \\
\text { penanaman }\end{array}$ & $\begin{array}{l}\text { Sekunder- } \\
\text { primer }\end{array}$ & $\begin{array}{l}\text { Pemerintah } \\
\text { kota, lapang }\end{array}$ \\
\hline 8 & Vegetasi & Fungsi, estetika, pengelolaan & primer & $\begin{array}{l}\text { Pemerintah } \\
\text { kota, lapang }\end{array}$ \\
\hline 9 & Pengelolaan & $\begin{array}{l}\text { Tindakan pemeliharaan, unit } \\
\text { pekerja, peralatan }\end{array}$ & $\begin{array}{l}\text { Sekunder, } \\
\text { primer }\end{array}$ & $\begin{array}{l}\text { Pemerintah } \\
\text { kota, lapang }\end{array}$ \\
\hline
\end{tabular}

Penentuan Segmen Jalan

Penelitian dilakukan terhadap 4 jalan yang dibagi menjadi 17 segmen berdasarkan komposisi dan jenis tanaman di lapang (Gambar 14-18), yaitu:

1. Jalan Cut Nyak Dien

Segmen 1 : Samping Balai Dang Merdu - Dinas Pendidikan

Segmen 2 : Dinas Pendidikan - Dinas Pekerjaan Umum

Segmen 3 : Kantor Gubernur - Perpustakaan Daerah

Segmen 4 : Bank Indonesia - Dinas Perkebunan dan Pertanian

2. Jalan Jendral Sudirman

Segmen 1 : Pelabuhan Pelita Pantai - Pasar Buah Pekanbaru

Segmen 2 : Pasar Buah Pekanbaru - Kantor Telkom

Segmen 3 : Kantor Telkom - Bundaran Tugu Pesawat Terbang

Segmen 4: Kantor Gubernur - Bundaran Air Mancur

Segmen 5 : Kantor Kehutanan - Gramedia

Segmen 6 : Gramedia - Pasar Dupa

Segmen 7 : Pasar Dupa- Simpang tiga Jalan Nasution

Segmen 8: Simpang tiga Jalan Nasution - bundaran Bandara Sultan Syarif

Qasim II

3. Jalan Gajah Mada

Segmen 1 : Kantor KPU - Polda Riau

4. Jalan Pangeran Diponegoro

Segmen 1 : Kampus UNRI kedokteran - Jalan Petala Bumi

Segmen 2 : Rumah gubernur - Balai Adat Riau

Segmen 3 : Balai Adat Riau - Taman Kota

Segmen 4 : Kantor Dharma Wanita - MAN Model 


\section{Pengamatan dan Penilaian Fungsi Tanaman Lanskap Jalan}

Nilai fungsional digunakan untuk mengevaluasi fungsi dari tanaman pada lanskap jalan. Metode akan dilakukan yaitu mengamati fungsi tanaman dalam mempengaruhi kualitas lingkungan.

Penilaian dilakukan dengan memberi skor terhadap setiap aspek fungsi tanaman. Nilai fungsional yang akan diamati antara lain : fungsi pengarah, fungsi pembatas, fungsi peneduh, kontrol bunyi, kontrol cahaya, kontrol polusi, pemberi identitas.

Penilaian tiap fungsi dilakukan sesuai referensi dan kriteria penilaian fungsi tanaman didapatkan dari berbagai sumber sesuai dengan ilmu Arsitektur Lanskap (Tabel 2). Skala nilai yang diberikan pada tiap kriteria yaitu 1-4.

Tabel 2. Kriteria Penilaian fungsi tanaman

\begin{tabular}{|c|c|c|c|c|}
\hline No & Fungsi & Kriteria Penilaian & Penilaian & Nilai Ideal \\
\hline \multirow[t]{6}{*}{1} & \multirow[t]{6}{*}{ Pengarah } & $\begin{array}{l}\text { 1. Perdu dengan ketinggian } 3-<6 \mathrm{~m} \text { atau } \\
\text { Pohon dengan ketinggian } / 6 \mathrm{~m} \text {. }\end{array}$ & $1-4$ & 4 \\
\hline & & 2. Ditanam secara massal/berbaris & $1-4$ & 4 \\
\hline & & 3.Jarak tanaman rapat dengan interval teratur & $1-4$ & 4 \\
\hline & & 4.Berkesinambungan & $1-4$ & 4 \\
\hline & & 5.Berkesan rapi dan memudahkan orientasi & $1-4$ & 4 \\
\hline & & 6. Bertajuk Kolumnar/batang jelas & $1-4$ & 4 \\
\hline \multicolumn{3}{|r|}{ Jumlah Total } & $6-24$ & 24 \\
\hline \multirow[t]{4}{*}{2} & \multirow{4}{*}{$\begin{array}{l}\text { Pembatas } \\
\text { Visual }\end{array}$} & 1. Tanaman tinggi, perdu, atau semak $>1,5 \mathrm{~m}$ & $1-4$ & 4 \\
\hline & & 2. Massa daun rapat/rimbun & $1-4$ & 4 \\
\hline & & 3. Jarak tanam rapat $<3 \mathrm{~m}$, tajuk bersinggungan & $1-4$ & 4 \\
\hline & & 4. Ditanam berbaris atau membentuk massa & $1-4$ & 4 \\
\hline \multicolumn{3}{|r|}{ Jumlah Total } & $4-16$ & 16 \\
\hline \multirow[t]{6}{*}{3} & \multirow[t]{6}{*}{ Peneduh } & 1. Pohon dengan tinggi sedang/tinggi $<15 \mathrm{~m}$ & $1-4$ & 4 \\
\hline & & 2. Bentuk spreading, bulat, dome, irregular & $1-4$ & 4 \\
\hline & & 3. Tajuk bersingunggan & $1-4$ & 4 \\
\hline & & 4. Massa daun padat & $1-4$ & 4 \\
\hline & & 5. Percabangan $5 \mathrm{~m}$ di atas tanah & $1-4$ & 4 \\
\hline & & 6. Ditanam secara berkesinambungan/teratur & $1-4$ & 4 \\
\hline \multicolumn{3}{|r|}{ Jumlah Total } & $6-24$ & 24 \\
\hline \multirow[t]{5}{*}{6} & \multirow{5}{*}{$\begin{array}{c}\text { Kontrol } \\
\text { Bunyi }\end{array}$} & 1. Beberapa lapis tanaman & $1-4$ & 4 \\
\hline & & 2. Ditanam dekat tepi jalan & $1-4$ & 4 \\
\hline & & 3. Kombinasi pohon, perdu, semak & $1-4$ & 4 \\
\hline & & 4. Bermassa daun padat & $1-4$ & 4 \\
\hline & & 5. Terdapat variasi tajuk secara vertikal & $1-4$ & 4 \\
\hline \multicolumn{3}{|r|}{ Jumlah Total } & $5-20$ & 20 \\
\hline \multirow[t]{3}{*}{5} & \multirow{3}{*}{$\begin{array}{l}\text { Kontrol } \\
\text { Cahaya }\end{array}$} & 1. Ditanamam rapat/berkelompok & $1-4$ & 4 \\
\hline & & 2. Perdu tinggi $61,5 \mathrm{~m}$, pohon tinggi / $6 \mathrm{~m}$ & $1-4$ & 4 \\
\hline & & 3. Bermassa daun padat/ rimbun & $1-4$ & 4 \\
\hline & & Jumlah Total & $3-12$ & 12 \\
\hline
\end{tabular}




\begin{tabular}{|c|c|c|c|c|}
\hline No & Fungsi & Kriteria Penilaian & Penilaian & Nilai Ideal \\
\hline \multirow[t]{6}{*}{7} & \multirow{6}{*}{$\begin{array}{c}\text { Kontrol } \\
\text { Polusi }\end{array}$} & 1. Ditanam kontinyu & $1-4$ & 4 \\
\hline & & 2. Tajuk Bersingunggan & $1-4$ & 4 \\
\hline & & 3. Daun rimbun & $1-4$ & 4 \\
\hline & & 4. Kombinasi pohon, sedang $<15 \mathrm{~m}$ dan semak & $1-4$ & 4 \\
\hline & & 5. Berkapasitas tinggi, menguranggi polutan & $1-4$ & 4 \\
\hline & & 6. Toleran polutan & $1-4$ & 4 \\
\hline \multicolumn{3}{|r|}{ Jumlah Total } & $6-24$ & 24 \\
\hline \multirow[t]{4}{*}{4} & \multirow{4}{*}{$\begin{array}{l}\text { Pemberi } \\
\text { Identitas }\end{array}$} & 1. Mempunyai ciri khas yang kuat & $1-4$ & 4 \\
\hline & & 2. Tanaman asli daerah & $1-4$ & 4 \\
\hline & & 3. Tanaman memiliki nilai sejarah & $1-4$ & 4 \\
\hline & & 4. Pola menarik & $1-4$ & 4 \\
\hline & & Jumlah Total & $3-12$ & 12 \\
\hline
\end{tabular}

Sumber : Direktorat Bina Marga (1996), Carpenter et al. (1975), Wungkar (2005), Vitasari (2004), Widagdo (1998), Hidayat (2008).

Keterangan :

Nilai 1 : Buruk, bila isi pemenuhan kriteria dari luas area yang diamati [41\%

Nilai 2 : Sedang, bila isi pemenuhan kriteria dari luas area yang diamati $41-60 \%$

Nilai 3 : Baik, bila isi pemenuhan kriteria dari luas area yang diamati 61-80\%

Nilai 4 : Sangat Baik, bila isi pemenuhan kriteria dari luas area yang diamati $/ 81 \%$

Penilaian Estetika Tanaman Lanskap Jalan

Nilai estetika dievaluasi dengan metode Scenic Beauty Estimation (SBE) yang diperkenalkan oleh Daniel dan Boster (1976). Metode ini digunakan untuk menaksir nilai keindahan visual tanaman lanskap jalan kota. Penilaian akan dilakukan pada berbagai jenis view yang tercipta oleh tata hijau jalur hijau jalan. Tahap-tahap yang akan dilakukan yaitu :

\section{Pengumpulan Foto Lanskap}

Pengambilan foto akan dilakukan di segmen-segmen yang telah ditentukan. Pengambilan foto akan diawali dengan observasi awal daerah penelitian dan menentukan titik pengambilan foto. Pengambilan foto difokuskan pada penyusunan tanaman di lapang. Objek yang akan diamati yaitu pohon dan kombinasi tanaman. Setelah diamati di lapang, pengambilan foto difokuskan pada 3 jenis penyusunan tanaman, yaitu : 1. pohon massal sejenis, 2. pohon massal campuran, 3. massal campuran. Pohon massal sejenis merupakan pohon sejenis yang ditanam berjejer sepanjang jalan, pohon massal campuran merupakan beberapa jenis pohon berbeda yang ditanam di sepanjang jalan, dan massal campuran merupakan kombinasi penanaman pohon, perdu dan penutup tanah.

Pengambilan foto menggunakan kamera digital Samsung L 100 dengan 3264pixelx2448pixel. Pengambilan foto bertujuan untuk memberikan gambaran di lapang agar dapat dinilai oleh responden. Sudut dan jarak pengambilan foto pada 
tiap objek perlu untuk diperhatikan. Objek diambil pada jarak titik pandang tidak terhalang oleh benda lain. Tinggi pengambilan gambar yaitu setinggi mata manusia dan sejajar pandangan mata normal. Sudut pengambilan gambar yaitu $30^{\circ}$ ke kiri dan $30^{\circ}$ ke kanan dari garis badan jalan (Gambar 7).

Foto-foto hasil pengambilan gambar diseleksi dan didapatkan 60 foto berwarna (Lampiran 5) yang mewakili 3 kategori penyusunan penataan tanaman pada lapang. Foto-foto tersebut terdiri dari : 22 foto pohon massal sejenis, 12 foto pohon massal campuran, 26 massal campuran (pohon-perdu-penutup tanah). Foto-foto hasil seleksi mewakili gambaran keadaan di lapang.

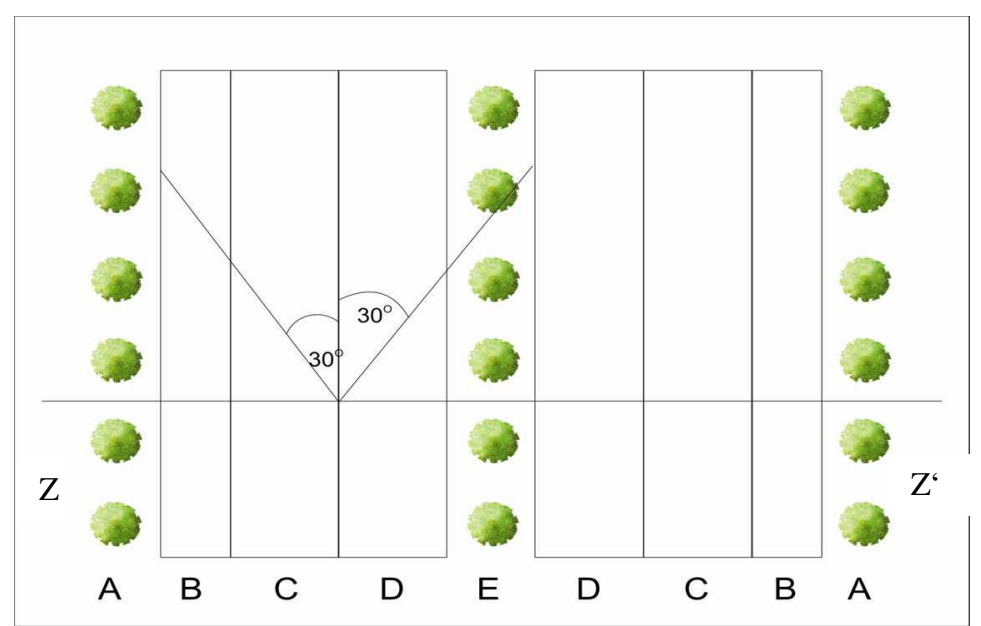

Keterangan :
A : Daerah milik jalan
D : Badan jalan
B : Parit pasangan batu kali
E : Median jalan
$\mathrm{C}:$ Bahu jalan
Z: Titik pemotretan

Gambar 7. Sudut Pengambilan Gambar

\section{Penilaian Slide Foto}

Foto- foto yang hasil seleksi digunakan sebagai bahan kuesioner. Foto-foto tersebut ditampilkan dalam bentuk slide ke depan responden dan tiap foto dinilai oleh responden.

Responden merupakan mahasiswa Arsitektur Lanskap semester 6 dan semester 8. Pemilihan responden mahasiswa Arsitektur Lanskap yaitu berdasarkan latar belakang ilmu yang dimiliki sehingga penilaian lebih akurat dan valid. 
Kuesioner berupa kolom pengisian penilaian dengan skala nilai 1-10 scenic beauty (Lampiran 1). Semakin mendekati 1 maka lanskap dinilai semakin tidak indah, semakin mendekati 10 maka lanskap dinilai semakin indah.

Prosedur dalam pengumpulan nilai estetika ini yaitu, pembagian lembar kuesioner, lalu dilanjutkan dengan penjelasan tujuan penilaian dan cara penilaian. Lalu slide foto-foto ditampilkan dalam durasi 8-10 detik tiap foto, responden memberi nilai tiap foto yang ditampilkan dan diakhiri dengan pengisian identitas responden.

\section{Pengamatan dan Penilaian Pengelolaan Tanaman Lanskap Jalan}

Evaluasi pengelolaan dilakukan terhadap tiap segmen jalan. Evaluasi pengelolaan menggunakan kriteria penilaian. Kriteria penilaian didapatkan dari berbagai referensi dalam bidang Arsitektur Lanskap (Tabel 3). Penilaian dilakukan berdasarkan pengamatan di lapang. Cara penilaian sama dengan evaluasi fungsi yaitu pemberian skor terhadap aspek pengelolaan yang diamati.

Tabel 3. Kriteria Penilaian Pengelolaan Tanaman

\begin{tabular}{|c|c|c|c|c|}
\hline No & Pengelolaan & Kriteria Penilaian & Penilaian & $\begin{array}{l}\text { Nilai } \\
\text { Ideal }\end{array}$ \\
\hline \multirow[t]{3}{*}{1} & \multirow[t]{3}{*}{ Segi desain } & $\begin{array}{l}\text { 1. Pengunaan pola tanaman yang sederhana/ tidak } \\
\text { rumit, (pemeliharaan mudah) }\end{array}$ & $1-4$ & 4 \\
\hline & & $\begin{array}{l}\text { 2. Pengunaan tanaman yang tidak memerlukan } \\
\text { perawatan intensif }\end{array}$ & $1-4$ & 4 \\
\hline & & $\begin{array}{l}\text { 3. Penggunaan tanaman yang mudah didapatkan } \\
\text { (penyulaman tanaman mudah) }\end{array}$ & $1-4$ & 4 \\
\hline \multicolumn{3}{|r|}{ Jumlah Total } & $3-16$ & 12 \\
\hline \multirow[t]{6}{*}{2} & \multirow[t]{6}{*}{ Segi Teknis } & $\begin{array}{l}\text { 1. Penyiraman dilakukan sesuai kebutuhan } \\
\text { tanaman }\end{array}$ & $1-4$ & 4 \\
\hline & & 2. Penyiangan dilakukan secara teratur & $1-4$ & 4 \\
\hline & & $\begin{array}{l}\text { 3. Pemangkasan dilakukan secara teratur sesuai } \\
\text { tujuan dan kebutuhan }\end{array}$ & $1-4$ & 4 \\
\hline & & 4. Pemupukan dilakukan secara teratur & $1-4$ & 4 \\
\hline & & 5. Penyulaman dilakukan sesuai kebutuhan & $1-4$ & 4 \\
\hline & & 6. Pengendalian HPT dilakukan secara teratur & $1-4$ & 4 \\
\hline & & Jumlah Total & $6-24$ & 24 \\
\hline
\end{tabular}

Sumber : Arifin dan Nurhayati (2000), Vitasari (2004).

Keterangan :

Nilai 1 : Buruk, bila isi pemenuhan kriteria dari luas area yang diamati [ $41 \%$

Nilai 2 : Sedang, bila isi pemenuhan kriteria dari luas area yang diamati $41-60 \%$

Nilai 3 : Baik, bila isi pemenuhan kriteria dari luas area yang diamati $61-80 \%$

Nilai 4 : Sangat Baik, bila isi pemenuhan kriteria dari luas area yang diamati $/ 81 \%$ 


\section{B. Analisis}

\section{Analisis Nilai Fungsional dan Pengelolaan}

Data penilaian fungsional dan pengelolaan yang diperoleh dianalisis nilai fungsional dan efektifitas pengelolaan penataan tanaman lanskap jalan. Nilai setiap kriteria dijumlahkan lalu nilai total kriteria dibandingkan dengan nilai idealnya (total maksimum). Lalu nilai yang diperoleh tersebut dipersentasekan dan dimasukkan ke dalam bobot penilaian (persentase akhir). Analisis dilakukan pada tiap segmen jalan secara deskriptif.

Bobot penilaian (persentase akhir) yaitu :

Buruk, [ $40 \%$ kriteria terpenuhi

Sedang, 41-60\% kriteria terpenuhi

Baik, 61-80\% kriteria terpenuhi

Sangat Baik, / $81 \%$ terpenuhi

\section{Analisis Nilai Estetika}

Data hasil penilaian kuesioner akan diolah dengan metode perhitungan SBE. Nilai (1-10) yang telah diberikan responden pada tiap gambar akan diolah. Tiap peringkat nilai dihitung frekuensi kumulatif, peluang kumulatif, nilai $\mathrm{Z}$ dan nilai $\mathrm{Z}$ rata-rata, lalu ditentukan satu nilai $\mathrm{Z}$ dari foto lanskap tertentu sebagai lanskap standar dengan nilai $\mathrm{Z}$ yang paling mendekati nol. Formulasi nilai SBE yaitu :

$$
\text { SBEx }=(\text { ZLx-ZLs }) \times 100
$$

SBEx = Nilai SBE lanskap ke-x

ZLx = Nilai rata-rata $\mathrm{Z}$ lanskap ke $\mathrm{x}$

ZLs = Nilai rata-rata Z lanskap standar

Setelah nilai SBE didapatkan, maka nantinya gambar dapat dikelompokkan ke dalam 3 kategori yaitu : 1. nilai keindahan tinggi, 2. nilai keindahan sedang, dan 3. nilai keindahan rendah. Penggelompokan dilakukan dengan menggunakan sebaran normal. Nilai SBE dirata-rata keseluruhannya lalu dihitung ragam dan simpangannya agar dapat dibuat selang kepercayaan untuk pengelompokkan nilai keindahan tinggi, sedang, rendah. 
Range nilai SBE untuk tiap penataan tanaman :

1. Pohon Massal Sejenis

Keindahan Tinggi : :0-33,5

Keindahan Sedang $\quad: 33,6-66,4$

Keindahan Rendah : $\quad 66,5-100$

2. Pohon Kelompok Campuran

Keindahan Tinggi : :0-34,2

Keindahan Sedang $\quad$ :34,3-68,2

Keindahan Rendah : $\quad 68,3-102,5$

3. Massal Campuran

Keindahan Tinggi $\quad$ 0-29,5

Keindahan Sedang : :29,6-59

Keindahan Rendah $\quad$ :58,9-88,4

Formulasi yang digunakan yaitu :

Selang Kepercayaan $(1-\infty) 100 \%$ bagi $\mu$ adalah :

$$
\frac{X-Z \propto \frac{\frac{\square}{2 \alpha}}{\sqrt{n}}<\mu<X+\frac{\alpha}{2 \alpha}}{\sqrt{n}}
$$

Perhitungan nilai tengah, ragam dan simpangan :

$$
\bar{z}=\frac{x-\mu}{\sigma}
$$

Ukuran pemusatan nilai tengah $(\mu)$ :

$$
\mu=\frac{\sum_{i=1}^{n} x_{i}}{n}
$$

Ukuran keragaman populasi $(\sigma)$ :

$$
\begin{array}{ll}
\sigma^{2}=\frac{\sum_{i=1}^{n}\left(x_{i}-[\mu) \rrbracket^{2}\right.}{n} & =\text { nilai tengah populasi } \\
\mu & =\text { jumlah data } \mathrm{x} 1, \mathrm{x} 2, \ldots, \\
\sum_{i=1}^{n} x_{i} & =\text { banyaknya populasi } \\
\mathrm{n} & =\text { ragam populasi } \\
\sigma^{2} & \\
\left.\sum_{i=1}^{n}\left(x_{i}-\varangle \mu\right)\right]^{2} &
\end{array}
$$


Setelah didapatkan pengelompokan nilai keindahan maka akan dilakukan pembahasan evaluasi penataan tanaman berdasarkan prinsip desain lanskap.

\section{Sintesis/Rekomendasi}

Data hasil analisis digunakan untuk menghasilkan rumusan rekomendasi untuk tiap segmen jalan. Rekomendasi berdasarkan kriteria penilaian. Rekomendasi tersebut dapat menjadi pertimbangan dalam meningkatkan fungsional, estetika dan pengelolaan tanaman lanskap jalan kota. Tahapan penelitian dapat dilihat pada Gambar 8.

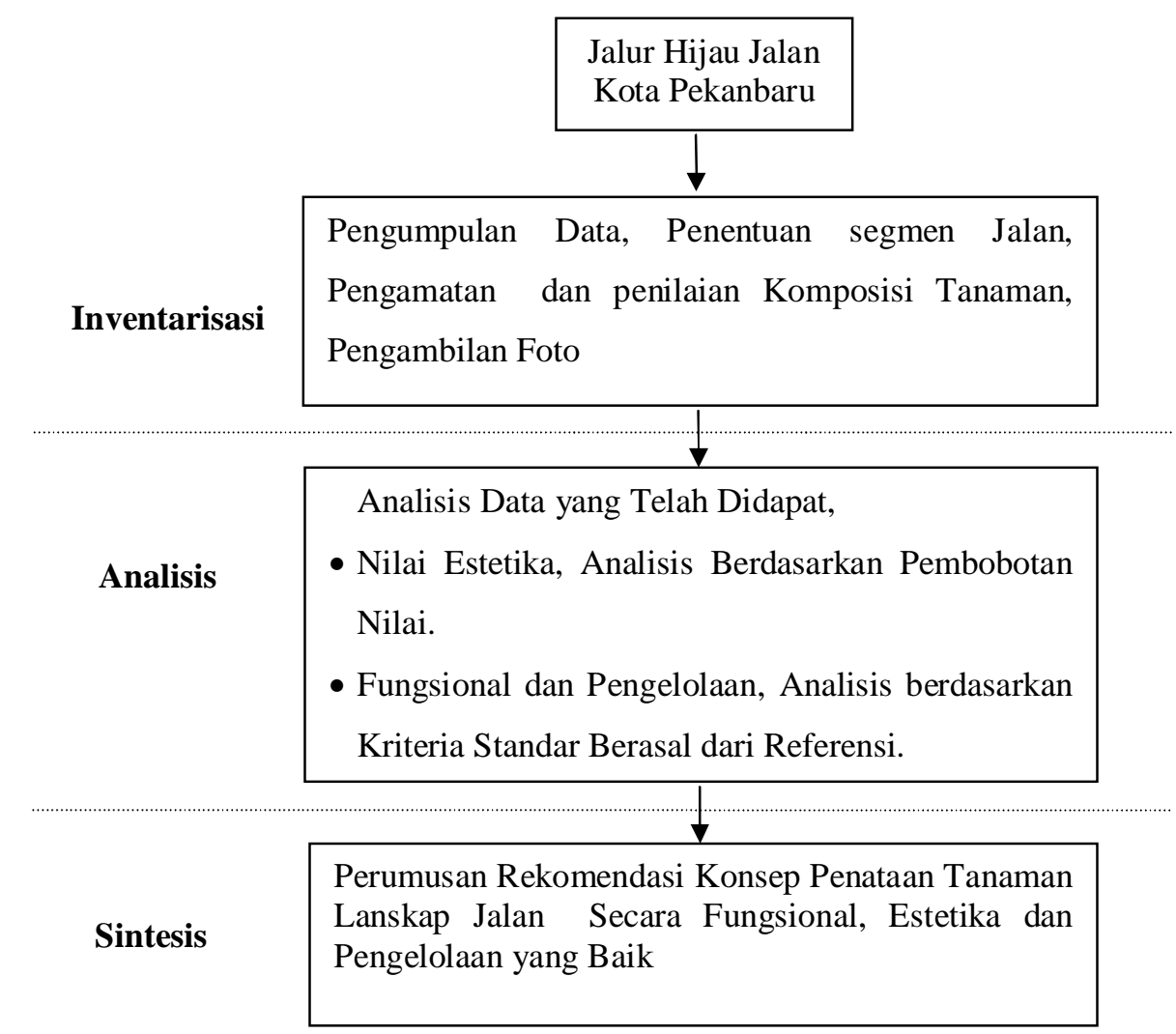

Gambar 8. Tahapan Penelitian 


\title{
HASIL DAN PEMBAHASAN
}

\author{
Kondisi Umum
}

\section{Letak Geografis}

Kota Pekanbaru secara astronomis terletak di antara $0^{\circ} 259-0^{\circ} 459$ Lintang Utara dan $101^{\circ} 149-101^{\circ} 349$ Bujur Timur. Kota Pekanbaru berbatasan di bagian utara dengan Kabupaten Siak dan Kabupaten Kampar, di bagian selatan berbatasan dengan Kabupaten Pelalawan dan Kabupaten Kampar, di bagian timur berbatasan dengan Kapubaten Siak dan Kabupaten Pelalawan, di bagian barat berbatasan dengan Kabupaten Kampar. Kota Pekanbaru memiliki luas wilayah sekitar 632,26 km² yang terdiri dari 12 kecamatan yaitu kecamatan Tampan, Bukit Raya, Lima Puluh, Sail, Pekanbaru Kota, Sukajadi, Senapelan, Rumbai, Rumbai Pesisir, Tenayan Raya, dan Marpoyan Damai. Kota pekanbaru terletak pada ketinggian rata-rata $5 \mathrm{~m}$ di atas permukaan laut.

\section{Geologi, Tanah, dan Topografi}

Secara geologis lahan Kota Pekanbaru terdiri atas formasi Minas yang dikelilingi oleh aluvium muda sepanjang aliran sungai Siak dan aluvium tua yang berawa-rawa. Lahan dari endapan aluvium muda yang terbentuk akibat pengangkutan dan pengendapan sisa-sisa bahan induk oleh aliran sungai. Karakteristik lahan ini yaitu rentan terhadap gangguan alami maupun pengolahan lahan yang berlebihan. Sebagian lahan Kota Pekanbaru juga mempunyai ciri formasi minas yang karakteristiknya lebih baik namun memiliki kandungan mineral lempung kaolinit yang mempunyai sifat porositas tanah rendah, yang dapat menahan senyawa aluminium, sehingga tanah bersifat asam dan sangat korosif terhadap material logam.

Struktur tanah Kota Pekanbaru umumnya berjenis aluvial dengan pasir, pinggiran kota umumnya terdiri dari jenis tanah organosol dan humus yang merupakan rawa-rawa bersifat masam, sangat korosif untuk besi. Pada daerah yang tinggi sebagian besar tanahnya berjenis podzolik merah kuning sedangkan di 
daerah yang lebih rendah berawa dan gambut berjenis tanah organosol/glei humus.

Kota Pekanbaru memiliki topografi beragam, yaitu landai, berombak sampai bergelombang. Secara umum kondisi wilayah Kota Pekanbaru merupakan dataran rendah dengan kemiringan lereng 0-2\%. Beberapa wilayah di bagian Utara dan Timur memiliki morfologi bergelombang dengan kemiringan di atas 40\%. Luasan wilayah dengan kemiringan lereng 0-20\% mencakup luasan yang cukup besar yaitu 566,56 ha atau 89,61\% dari luas wilayah secara keseluruhan.

\section{Iklim}

Suhu udara maksimum berkisar antara $32,6^{\circ} \mathrm{C}-36,5^{\circ} \mathrm{C}$ dan suhu udara minimum berkisar antara $21,0{ }^{\circ} \mathrm{C}-22,8{ }^{\circ} \mathrm{C}$. Kelembaban udara rata-rata $80,5 \%$.

Tabel 4. Data Iklim Kota Pekanbaru Tahun 2007

\begin{tabular}{|l|l|l|l|l|l|l|l|l|l|l|l|l|l|}
\hline \multicolumn{2}{|l|}{ Keterangan } & \multicolumn{10}{|c|}{ Bulan } & \multicolumn{10}{|c|}{} \\
\cline { 2 - 15 } & Jan & Feb & Mar & April & Mei & Juni & Juli & Agt & Sep & Okt & Nov & Des \\
\hline $\begin{array}{l}\text { Suhu } \\
\left(\mathrm{C}^{\mathrm{O}}\right)\end{array}$ & Max & 34,2 & 34,5 & 34,8 & 35,2 & 34,4 & 35,0 & 34,7 & 33,7 & 34,0 & 34,2 & 33,6 & 33,7 \\
\hline $\begin{array}{l}\text { Curah } \\
(\mathrm{mm})\end{array}$ & 22,0 & 21,0 & 22,0 & 22,8 & 21,4 & 22,4 & 21,2 & 21,5 & 22,0 & 22,2 & 22,0 & 22,0 \\
\hline $\begin{array}{l}\text { Kelembaban } \\
\text { udara rata-rata } \\
(\%)\end{array}$ & 279 & 206 & 234 & 371 & 308 & 181 & 182 & 208 & 336 & 502 & 393 & 148 \\
\hline Hari hujan & 21 & 18 & 17 & 21 & 18 & 18 & 20 & 19 & 21 & 23 & 21 & 20 \\
\hline
\end{tabular}

Sumber : Stasiun Meteorologi Sultan Syarif Qasim Pekanbaru II (2007).

Curah Hujan di Kota Pekanbaru rata- rata 279 mm/bulan. Keadaan musim yaitu untuk musim hujan jatuh pada bulan Januari s/d April dan September s/d Desember dan musim kemarau jatuh pada bulan Mei s/d Agustus.

\section{Hidrologi}

Kondisi hidrologi di Kota Pekanbaru dapat dibedakan menjadi dua bagian yaitu kondisi hidrologi air permukaan dan air tanah. Hidrologi air permukaan pada umumnya berasal dari sungai yang mengalir di Kota Pekanbaru yaitu Sungai Siak. Sungai Siak mempunyai anak-anak sungai di dalam kota yang berfungsi sebagai saluran utama pembuangan air limbah dan drainase. Sungai Siak mengalir dari barat ke timur, memiliki beberapa anak sungai antara lain: Sungai Umban Sari, Air Hitam, Sibam, Setukul, Pengambangan, Ukai, Sago, Senapelan, Limau dan Tampan. Sungai Siak yang merupakan Sungai terbesar yang membelah Kota Pekanbaru menjadi 2 bagian utara dan selatan, banyak anak sungai yang bermuara 
pada Sungai Siak, dengan demikian beban Sungai Siak dalam proses pendangkalan atau sedimentasi cukup besar. Sungai Siak juga merupakan jalur perhubungan lalu lintas perekonomian rakyat pedalaman ke kota serta dari daerah lainnya.

Hidrologi air tanah tanah terbagi dua, hidrologi air tanah dalam dan hidrologi air tanah dangkal. Hidrologi air tanah dalam kemungkinan berasal dari Formasi Petani, sifat air tanahnya kurang baik sebagai air minum. Sedangkan hidrologi air tanah dangkal berasal dari Formasi Minas. Mengingat kondisi batuan Formasi Minas yaitu memiliki permeabilitas dan porositas yang tinggi, maka Kota Pekanbaru memiliki potensi ketersediaan air tanah dangkal yang cukup banyak.

\section{Vegetasi}

Jalan- jalan utama pada Kota Pekanbaru pada umumnya memiliki pohonpohon yang telah tumbuh lama dan juga pohon-pohon yang baru ditanam. Bentuk arsitektural tajuknya pun beraneka ragam di sepanjang jalan. Pohon yang umum ditemukan di jalan di Kota Pekanbaru yaitu angsana, tanjung dan mahoni. Ketiga pohon tersebut adalah pohon yang dominan ditemukan, selain itu juga terdapat pohon ketapang, matoa, glodogan tiang, akasia. Vegetasi di sepanjang jalan kota pekanbaru sudah mulai tertata dengan baik. Karakteristik jenis pohon yang terdapat pada 4 jalan lokasi penelitian dapat dilihat pada Tabel 5. 
Tabel 5. Karakteristik Pohon Pada Jalan Lokasi

\begin{tabular}{|c|c|c|c|c|c|c|c|c|c|c|c|c|c|c|c|c|c|c|}
\hline \multirow[t]{2}{*}{ Nama Jalan } & \multirow[b]{2}{*}{ : } & \multirow[t]{2}{*}{ Nama pohon } & \multicolumn{7}{|c|}{ Bentuk tajuk } & \multicolumn{7}{|c|}{ Fungsi pohon } & \multirow[t]{2}{*}{ Jarak tanam pohon $(\mathrm{m})$} & \multirow[t]{2}{*}{ Tinggi rata-rata } \\
\hline & & & 흄 & 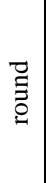 & 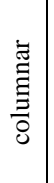 & 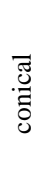 & 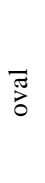 & 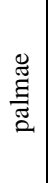 & 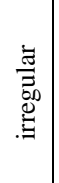 & 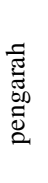 & 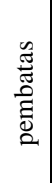 & $\begin{array}{l}\bar{\Xi} \\
\bar{\Xi} \\
\bar{\Xi} \\
\check{\Xi}\end{array}$ & 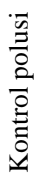 & 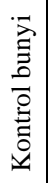 & 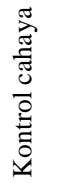 & 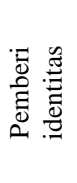 & & \\
\hline \multirow{11}{*}{$\begin{array}{c}\text { Cut Nyak } \\
\text { Dien }\end{array}$} & \multirow[t]{2}{*}{1} & Mahoni & & $\mathrm{v}$ & & & & & & $\mathrm{v}$ & $\mathrm{v}$ & $\mathrm{v}$ & & & $\mathrm{v}$ & $\mathrm{v}$ & Sedang & $15-30$ \\
\hline & & Palem ekor tupai & & & & & & $\mathrm{v}$ & & $\mathrm{v}$ & & & & & & $\mathrm{v}$ & Sedang & $3-6$ \\
\hline & \multirow[t]{2}{*}{2} & Mahoni & & $\mathrm{v}$ & & & & & & $\mathrm{v}$ & $\mathrm{v}$ & $\mathrm{v}$ & & & $\mathrm{v}$ & $\mathrm{v}$ & Sedang & $15-30$ \\
\hline & & Palem raja & & & & & & $\mathrm{v}$ & & $\mathrm{v}$ & & & & & & $\mathrm{v}$ & Sedang & $25-30$ \\
\hline & \multirow[t]{5}{*}{3} & Mahoni & & $\mathrm{v}$ & & & & & & $\mathrm{v}$ & $\mathrm{v}$ & $\mathrm{v}$ & & & $\mathrm{v}$ & $\mathrm{v}$ & Rapat & $15-30$ \\
\hline & & Cemara lilin & & & & $\mathrm{v}$ & & & & $\mathrm{v}$ & $\mathrm{v}$ & & & & & & Rapat & $5-6$ \\
\hline & & Palem putri & & & & & & $\mathrm{v}$ & & $\mathrm{v}$ & & & & & & & Kurang rapat & $4-5$ \\
\hline & & Cassia glauca & & & & & & & $\mathrm{v}$ & & & & & & & & Kurang rapat & 5 \\
\hline & & Kembang merak & & & & & & & $\mathrm{v}$ & & $\mathrm{v}$ & & $\mathrm{v}$ & & & & Kurang rapat & $2-3$ \\
\hline & \multirow[t]{2}{*}{4} & Tanjung & & $\mathrm{v}$ & & & & & & $\mathrm{v}$ & $\mathrm{v}$ & $\mathrm{v}$ & & & $\mathrm{v}$ & & Sedang & $10-15$ \\
\hline & & Mahoni & & $\mathrm{v}$ & & & & & & $\mathrm{v}$ & $\mathrm{v}$ & $\mathrm{v}$ & & & $\mathrm{v}$ & $\mathrm{v}$ & Rapat & $15-30$ \\
\hline \multirow[t]{16}{*}{ Sudirman } & 1 & Angsana & & $\mathrm{v}$ & & & & & & $\mathrm{v}$ & $\mathrm{v}$ & $\mathrm{v}$ & $\mathrm{v}$ & $\mathrm{v}$ & $\mathrm{v}$ & & Sedang & $15-40$ \\
\hline & 2 & Angsana & & $\mathrm{v}$ & & & & & & $\mathrm{v}$ & $\mathrm{v}$ & $\mathrm{v}$ & $\mathrm{v}$ & $\mathrm{v}$ & $\mathrm{v}$ & . & Sedang & $15-40$ \\
\hline & \multirow[t]{2}{*}{3} & Mahoni & & $\mathrm{v}$ & & & & & & $\mathrm{v}$ & $\mathrm{v}$ & $\mathrm{v}$ & & & $\mathrm{v}$ & $\mathrm{v}$ & Sedang & $15-30$ \\
\hline & & Angsana & & & & & & & & & & & & & & & Sedang & $15-40$ \\
\hline & \multirow[t]{3}{*}{\begin{tabular}{l|l}
4 \\
\end{tabular}} & Mahoni & & $\mathrm{v}$ & & & & & & $\mathrm{v}$ & $\mathrm{v}$ & $\mathrm{v}$ & & & $\mathrm{v}$ & $\mathrm{v}$ & Sedang & $15-30$ \\
\hline & & Bintaro & & $\mathrm{v}$ & & & & & & $\mathrm{v}$ & $\mathrm{v}$ & $\mathrm{v}$ & & & $\mathrm{v}$ & $\mathrm{v}$ & Rapat & $3-5$ \\
\hline & & Angsana & & $\mathrm{v}$ & & & & & & $\mathrm{v}$ & $\mathrm{v}$ & $\mathrm{v}$ & $\mathrm{v}$ & $\mathrm{v}$ & $\mathrm{v}$ & & Kurang rapat & $15-40$ \\
\hline & \multirow[t]{2}{*}{5} & Mahoni & & $\mathrm{v}$ & & & & & & $\mathrm{v}$ & $\mathrm{v}$ & $\mathrm{v}$ & & & $\mathrm{v}$ & $\mathrm{v}$ & Rapat & $15-30$ \\
\hline & & Bintaro & & $\mathrm{v}$ & & & & & & $\mathrm{v}$ & $\mathrm{v}$ & $\mathrm{v}$ & & & $\mathrm{v}$ & $\mathrm{v}$ & Rapat & $3-5$ \\
\hline & \multirow[t]{2}{*}{6} & Mahoni & & $\mathrm{v}$ & & & & & & $\mathrm{v}$ & $\mathrm{v}$ & $\mathrm{v}$ & & & $\mathrm{v}$ & $\mathrm{v}$ & Sedang & $15-30$ \\
\hline & & Angsana & & $\mathrm{v}$ & & & & & & $\mathrm{v}$ & $\mathrm{v}$ & $\mathrm{v}$ & $\mathrm{v}$ & $\mathrm{v}$ & $\mathrm{v}$ & & Sedang & $15-40$ \\
\hline & \multirow[t]{2}{*}{7} & Mahoni & & $\mathrm{v}$ & & & & & & $\mathrm{v}$ & $\mathrm{v}$ & $\mathrm{v}$ & & & $\mathrm{v}$ & $\mathrm{v}$ & Sedang & $15-30$ \\
\hline & & Palem raja & & & & & & $\mathrm{v}$ & & $\mathrm{v}$ & & & & & & $\mathrm{v}$ & Kurang rapat & $25-30$ \\
\hline & \multirow[t]{3}{*}{8} & Kelapa sawit & & & & & & $\mathrm{v}$ & & $\mathrm{v}$ & & & & & & $\mathrm{v}$ & Sedang & 630 \\
\hline & & Kembang merak & & & & & & & $\mathrm{v}$ & & $\mathrm{v}$ & & & $\mathrm{v}$ & & & Rapat & $2-3$ \\
\hline & & Cassia glauca & & & & & & & $\mathrm{v}$ & & & & & & & & Rapat & 5 \\
\hline $\begin{array}{l}\text { Gajah } \\
\text { Mada }\end{array}$ & 1 & Mahoni & & $\mathrm{v}$ & & & & & & $\mathrm{v}$ & $\mathrm{v}$ & $\mathrm{v}$ & & & $\mathrm{v}$ & $\mathrm{v}$ & Rapat & $15-30$ \\
\hline \multirow[t]{6}{*}{ Diponegoro } & \multirow[t]{3}{*}{1} & Tanjung & & $\mathrm{v}$ & & & & & & $\mathrm{v}$ & $\mathrm{v}$ & $\mathrm{v}$ & & & $\mathrm{v}$ & & Sedang & $10-15$ \\
\hline & & Palem ekor tupai & & & & & & $\mathrm{v}$ & & $\mathrm{v}$ & & & & & & $\mathrm{v}$ & Sedang & $3-6$ \\
\hline & & Bintaro & & $\mathrm{v}$ & & & & & & $\mathrm{v}$ & $\mathrm{v}$ & $\mathrm{v}$ & & & $\mathrm{v}$ & $\mathrm{v}$ & Sedang & $3-6$ \\
\hline & \multirow[t]{3}{*}{2} & Mahoni & & $\mathrm{v}$ & & & & & & $\mathrm{v}$ & $\mathrm{v}$ & $\mathrm{v}$ & & & $\mathrm{v}$ & $\mathrm{v}$ & Sedang & $15-30$ \\
\hline & & Palem ekor tupai & & & & & & $\mathrm{v}$ & & $\mathrm{v}$ & & & & & & $\mathrm{v}$ & Sedang & $3-6$ \\
\hline & & Bintaro & & $\mathrm{v}$ & & & & & & $\mathrm{v}$ & $\mathrm{v}$ & $\mathrm{v}$ & & & $\mathrm{v}$ & $\mathrm{v}$ & Sedang & $3-5$ \\
\hline
\end{tabular}




\begin{tabular}{|c|c|c|c|c|c|c|c|c|c|c|c|c|c|c|c|c|c|c|}
\hline \multirow[t]{2}{*}{ Nama Jalan } & \multirow[b]{2}{*}{$\begin{array}{l}\text { : } \\
\text { : } \\
0\end{array}$} & \multirow[t]{2}{*}{ Nama pohon } & \multicolumn{7}{|c|}{ Bentuk tajuk } & \multicolumn{7}{|c|}{ Fungsi pohon } & \multirow[t]{2}{*}{ Jarak tanam pohon $(\mathrm{m})$} & \multirow[t]{2}{*}{ Tinggi rata-rata } \\
\hline & & & & $\begin{array}{l}\vec{\Xi} \\
\stackrel{\Xi}{0}\end{array}$ & $\begin{array}{l}\stackrel{\Xi}{\Xi} \\
\vdots \\
\end{array}$ & 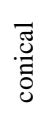 & हू & $\frac{\mathscr{\Xi}}{\stackrel{\Xi}{\Xi}}$ & 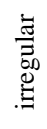 & 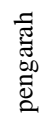 & 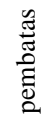 & 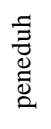 & 호영 & 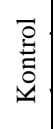 & 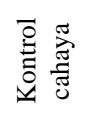 & 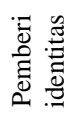 & & \\
\hline & 3 & Mahoni & & $\mathrm{v}$ & & & & & & $\mathrm{v}$ & $\mathrm{v}$ & $\mathrm{v}$ & & & $\mathrm{v}$ & $\mathrm{v}$ & Sedang & $15-30$ \\
\hline & & Glodogan bulat & & & & $\mathrm{v}$ & & & & $\mathrm{v}$ & $\mathrm{v}$ & & & & & & Rapat & $15-20$ \\
\hline & & Palem ekor tupai & & & & & & $\mathrm{v}$ & & $\mathrm{v}$ & & & & & & $\mathrm{V}$ & Sedang & $3-6$ \\
\hline & & Bintaro & & $\mathrm{v}$ & & & & & & $\mathrm{v}$ & $\mathrm{v}$ & $\mathrm{v}$ & & & $\mathrm{v}$ & $\mathrm{v}$ & Rapat & $3-5$ \\
\hline & 4 & Mahoni & & $\mathrm{v}$ & & & & & & $\mathrm{v}$ & $\mathrm{v}$ & $\mathrm{v}$ & & & $\mathrm{v}$ & $\mathrm{v}$ & Sedang & $15-30$ \\
\hline & & Bintaro & & $\mathrm{v}$ & & & & & & $\mathrm{v}$ & $\mathrm{v}$ & $\mathrm{v}$ & & & $\mathrm{v}$ & $\mathrm{v}$ & Sedang & $3-5$ \\
\hline & & Palem ekor tupai & & & & & & $\mathrm{v}$ & & $\mathrm{v}$ & & & & & & $\mathrm{v}$ & Sedang & $3-6$ \\
\hline & & & & & & & & & & & & & & & & & & \\
\hline
\end{tabular}

Sumber : Wungkar (2005), Galeri Tanaman Tanaman Hias Lanskap (2008), Hasil pengamatan

Keterangan :

Rapat : : [3m

Sedang $\quad: 4-5 \mathrm{~m}$

Kurang rapat : $/ 6 \mathrm{~m}$ 
Jalan

\section{Lokasi dan dimensi jalan}

Penelitian dilakukan pada jalan yang setiap harinya dipadati kendaraan bermotor dan merupakan jalan yang berada pada pusat Kota Pekanbaru. Jalan yang dijadikan objek penelitian antara lain Jalan Sudirman, Jalan Diponegoro, Jalan Cut Nyak Dien, dan Jalan Gajah Mada.

Jalan Cut Nyak Dien ada yang memiliki satu badan jalan tanpa median jalan dan dua badan jalan dengan satu median jalan. Jalan ini memiliki panjang 1,2 km. Jalan Cut Nyak Dien termasuk kedalam jalan kolektor sekunder. Jalan Cut Nyak Dien merupakan jalan yang terdapat pada komplek perkantoran pemerintahan. Pada penelitian jalan ini dibagi menjadi 4 segmen (Gambar 14).

Jalan Sudirman terdapat di Kecamatan Pekanbaru Kota. Jalan ini merupakan jalan terpanjang di Pekanbaru dengan panjang jalan $9 \mathrm{~km}$. Jalan ini menghubungkan lapangan udara Sultan Syarif Qasim II dan pelabuhan laut Pelita Pantai. Jalan Sudirman merupakan jalan arteri sekunder. Jalan Sudirman memiliki dua badan jalan dan satu median jalan. Jalan ini pada pengamatan di lapang dibagi menjadi 8 segmen (Gambar 15 dan 16).

Jalan Gajah Mada terdapat pada Kecamatan Pekanbaru Kota. Jalan ini termasuk kedalam kategori jalan kolektor sekunder. Jalan Gajah Mada merupakan jalan yang menghubungkan kantor gubernur yang berada pada Jalan Sudirman dengan rumah gubernur yang berada pada Jalan Diponegoro. Panjang jalan ini yaitu $0,8 \mathrm{~km}$. Jalan ini dibagi menjadi 1 segmen jalan (Gambar 17). Jalan Gajah Mada memiliki dua badan jalan tanpa median jalan.

Jalan Diponegoro adalah jalan kolektor sekunder yan memiliki panjang sekitar 2,7 km. Jalan ini memiliki dua jalur jalan dengan satu median. Jalan Diponegoro menghubungkan Jalan Hangtuah dan Jalan Patimura. Jalan ini dibagi menjadi 4 segmen (Gambar 18).

Pembagian segmen pada tiap jalan dilakukan setelah dilakukan pengamatan di lapang berdasarkan komposisi tanaman dan jenis tanaman yang ada pada jalan yang diamati (Tabel 9). Kondisi pada tiap jalan yang diteliti dapat 
dilihat pada Tabel 6 dan dimensi jalan dapat dilihat pada Gambar 9, 10, 11, 12 dan 13.

Tabel 6. Kondisi Jalan Tempat Penelitian

\begin{tabular}{|l|l|l|l|l|l|l|l|l|l|l|l|l|}
\hline No & Nama Jalan & & & & \multicolumn{2}{|l|}{ Lebar (M) } & \multicolumn{2}{l|}{ Perkerasa } \\
n
\end{tabular}

Sumber : Dinas Pekerjaan Umum Kota Pekanbaru (2008)

Keterangan :
P : Propinsi
Ar : Arteri
As : Aspal
R : Rumput
K : Kota
$\mathrm{Kl}$ : Kolektor
B : Baik
$\mathrm{C}:$ Conblock

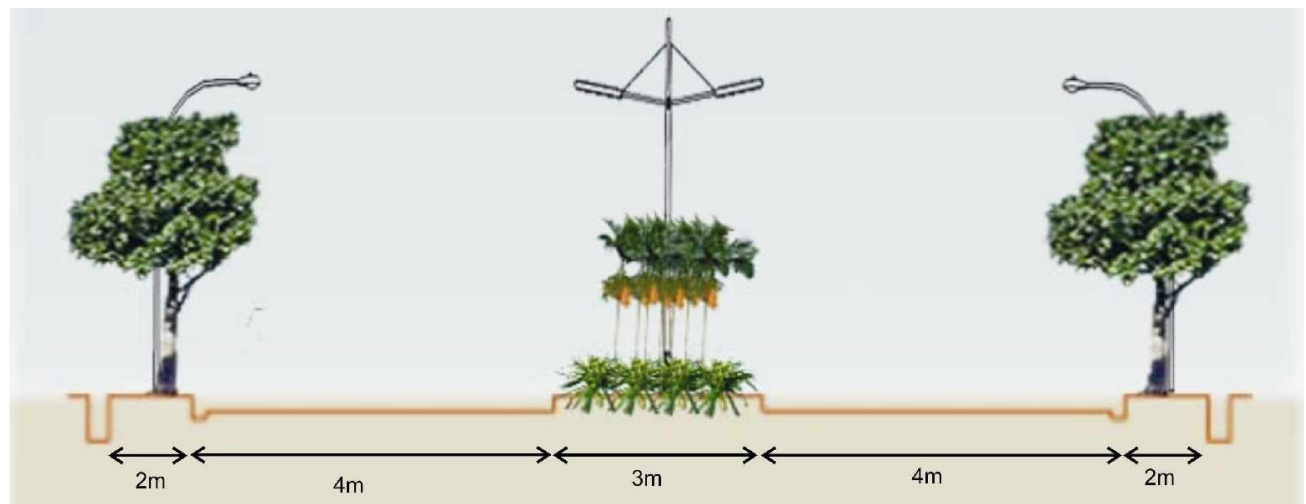

Gambar 9. Dimensi Jalan Cut Nyak Dien dengan Median

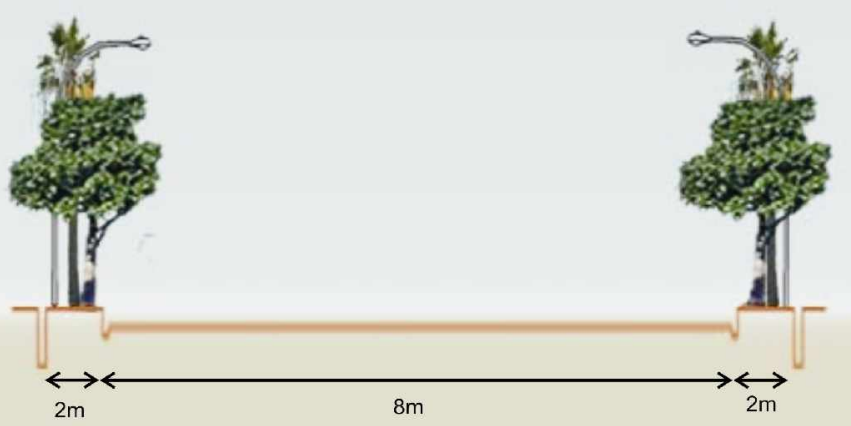

Gambar 10. Dimensi Jalan Cut Nyak Dien Tanpa Median 


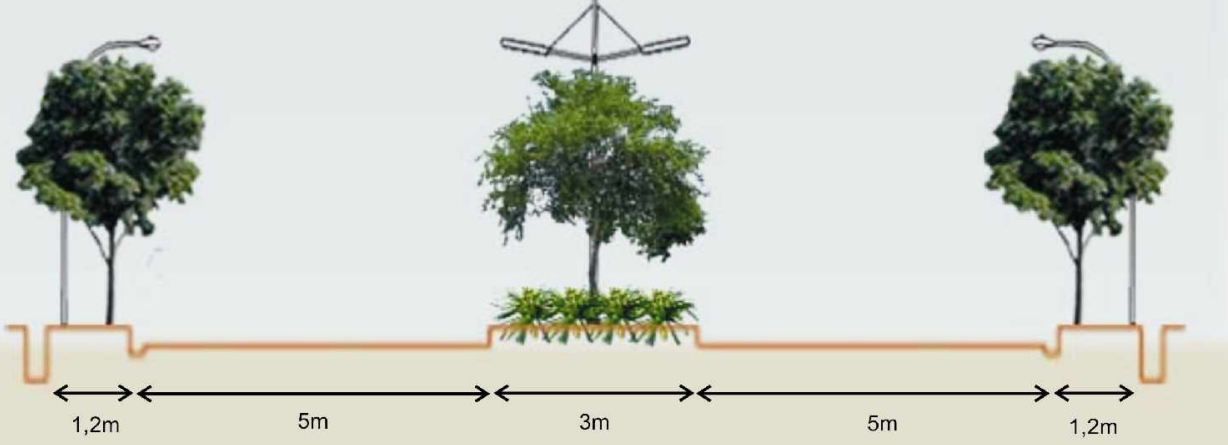

Gambar 11. Dimensi Jalan Sudirman

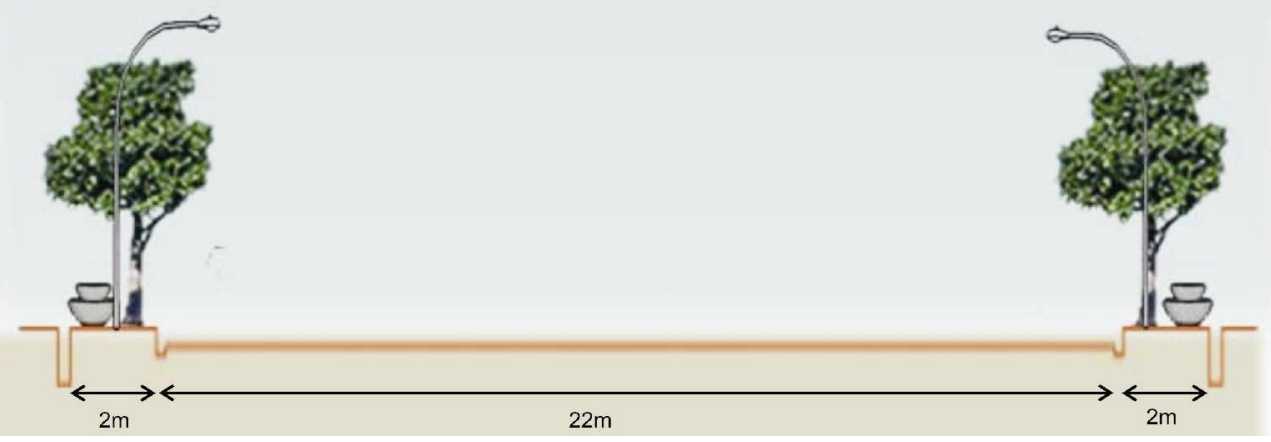

Gambar 12. Dimensi Gajah Mada

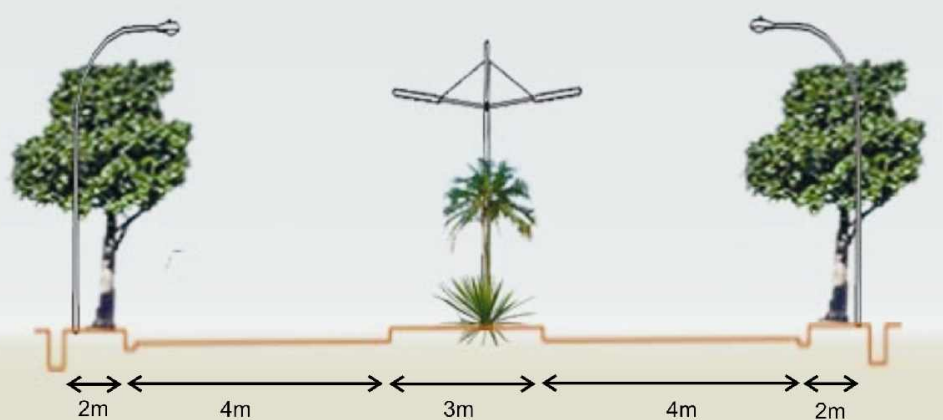

Gambar 13. Dimensi Jalan Pangeran Diponegoro 


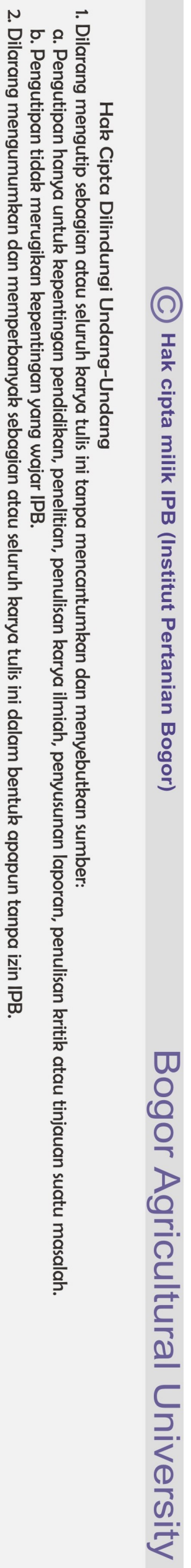




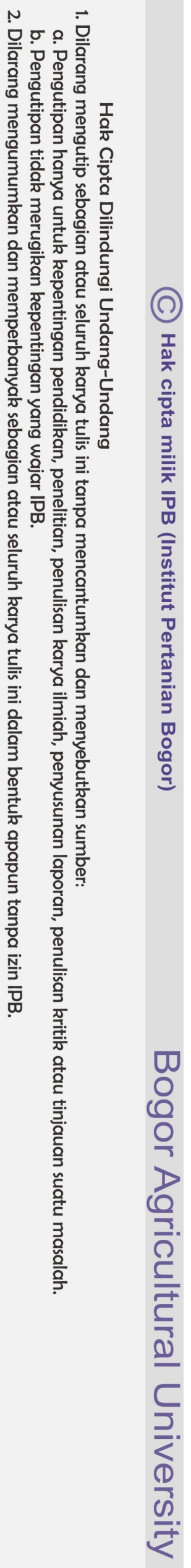




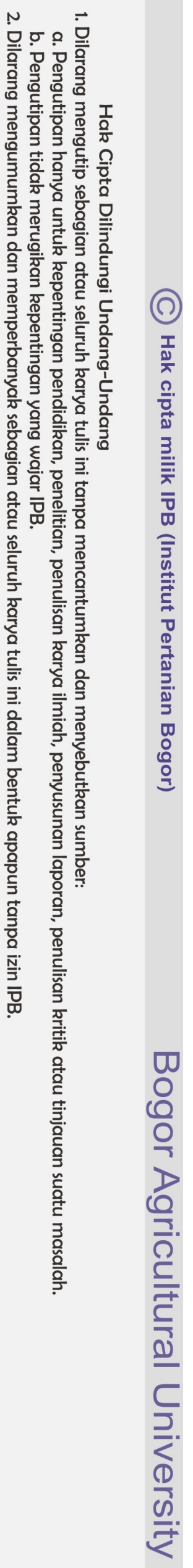




\section{Elemen pembentuk tapak}

A. Elemen Tanaman

Jalan-jalan pada Kota Pekanbaru juga berfungsi sebagai ruang terbuka hijau kota. Pada jalur hijau jalan ditanami tanaman dengan fungsi dan bentuk arsitektural beragam. Tanaman merupakan elemen utama pembentuk lanskap jalan. Elemen tanaman yang terdapat pada jalan lokasi penelitian antara lain :

1. Pohon yang memiliki berbagai macam bentuk tajuk. Pohon berfungsi antara lain sebagai pengarah, peneduh, kontrol silau matahari, dan memberikan kualitas visual yang menarik bagi pengguna jalan.

2. Semak/perdu berfungsi sebagai pembatas, kontrol polusi, pengarah, kontrol polusi dan juga memberikan nilai estetik pada jalan.

3. Penutup tanah umumnya berfungsi sebagai pemberi nilai estetik dan pembatas jalan.

4. Rumput sebagai alas dan pemberi nilai estetik

Jenis tanaman yang terdapat pada lokasi penelitian dapat dilihat pada Tabel 7.

Tabel 7. Jenis Tanaman Pada Lokasi Penelitian

\begin{tabular}{|c|c|c|c|c|c|}
\hline \multirow[t]{2}{*}{ Nama Ilmiah } & \multirow[t]{2}{*}{ Nama Lokal } & \multicolumn{4}{|c|}{ Lokasi } \\
\hline & & $\begin{array}{c}\text { Cut Nyak } \\
\text { Dien }\end{array}$ & Sudirman & $\begin{array}{l}\text { Gajah } \\
\text { Mada }\end{array}$ & Diponegoro \\
\hline \multicolumn{6}{|l|}{ Pohon } \\
\hline Acacia mangium & Akasia & $\mathrm{V}$ & $\mathrm{V}$ & & $\mathrm{V}$ \\
\hline Caesilpinia pulcherrima & Bunga Merak & $\mathrm{V}$ & $\mathrm{V}$ & & $\mathrm{V}$ \\
\hline Cassia fistula & Kasia Golden & & $\mathrm{V}$ & & \\
\hline Cassia surattensis & Cassia Glauca & $\mathrm{V}$ & $\mathrm{V}$ & & \\
\hline Cerbera manghas & Bintaro & $\mathrm{V}$ & V & & $\mathrm{V}$ \\
\hline Cyrtotachis lakka & Palem Merah & $\mathrm{V}$ & $\mathrm{V}$ & & $\mathrm{V}$ \\
\hline $\begin{array}{l}\text { Chrysalidocarpus } \\
\text { lutescens }\end{array}$ & Palem Kuning & & & & \\
\hline Cupressus sempervirens & Cemara Lilin & $\mathrm{V}$ & $\mathrm{V}$ & & \\
\hline Delonix regia & Flamboyan & & $\mathrm{V}$ & & $\mathrm{V}$ \\
\hline Elaesis guinensis & Kelapa Sawit & & $\mathrm{V}$ & & \\
\hline Filicium decipiens & Kerai Payung & & $\mathrm{V}$ & & $\mathrm{V}$ \\
\hline Mimusoph elengi & Tanjung & $\mathrm{V}$ & $\mathrm{V}$ & & $\mathrm{V}$ \\
\hline Polyalthia fragrans & Glodogan bulat & & & & $\mathrm{V}$ \\
\hline Polyalthia longifolia & Glodogan & $\mathrm{V}$ & & & \\
\hline Pometia pinnata & Matoa & $\mathrm{V}$ & & & \\
\hline Plumeria $s p$ & Kamboja & & & & $\mathrm{V}$ \\
\hline Pterocarpus indicus & Angsana & & $\mathrm{V}$ & & \\
\hline Roystonea regia & Palem Raja & & $\mathrm{V}$ & & \\
\hline Swietenia mahogani & Mahoni & $\mathrm{V}$ & $\mathrm{V}$ & $\mathrm{V}$ & $\mathrm{V}$ \\
\hline Termelia cattapa & Ketapang & $\mathrm{V}$ & $\mathrm{V}$ & & \\
\hline Veitchia merilii & Palem Putri & $\mathrm{V}$ & $\mathrm{V}$ & & $\mathrm{V}$ \\
\hline
\end{tabular}


Tabel 7. (Lanjutan)

\begin{tabular}{|c|c|c|c|c|c|}
\hline \multirow[t]{2}{*}{ Nama Ilmiah } & \multirow[t]{2}{*}{ Nama Lokal } & \multicolumn{4}{|c|}{ Lokasi } \\
\hline & & $\begin{array}{c}\text { Cut Nyak } \\
\text { Dien }\end{array}$ & Sudirman & $\begin{array}{l}\text { Gajah } \\
\text { Mada }\end{array}$ & Diponegoro \\
\hline \multirow[t]{2}{*}{ Wodyetia bifurcata } & $\begin{array}{ll}\text { Palem } & \text { Ekor } \\
\text { Tupai } & \end{array}$ & $\mathrm{V}$ & $\mathrm{V}$ & & $\mathrm{V}$ \\
\hline & Cemara Udang & $\mathrm{V}$ & $\mathrm{V}$ & $\mathrm{V}$ & \\
\hline \multicolumn{6}{|l|}{ Perdu/Semak } \\
\hline Acalypha macrophylla & Teh-tehan & & $\mathrm{V}$ & & $\mathrm{V}$ \\
\hline Agave $\mathrm{sp}$ & Agave & & $\mathrm{V}$ & & \\
\hline Arundinaria pumila & Bambu Jepang & & & $\mathrm{V}$ & $\mathrm{V}$ \\
\hline Bougenvillea $\mathrm{sp}$ & Bogenvil & $\mathrm{V}$ & $\mathrm{V}$ & $\mathrm{V}$ & $\mathrm{V}$ \\
\hline Canna sp & Bunga Tasbih & $\mathrm{V}$ & $\mathrm{V}$ & & \\
\hline Dracaena sp & Drasena & $\mathrm{V}$ & $\mathrm{V}$ & $\mathrm{V}$ & $\mathrm{V}$ \\
\hline Duranta $\mathrm{sp}$ & \begin{tabular}{|l|} 
Pangkas \\
Kuning
\end{tabular} & V & $\mathrm{V}$ & V & $\mathrm{V}$ \\
\hline Heliconia $\mathrm{sp}$ & Pisang Hias & $\mathrm{V}$ & & $\mathrm{V}$ & $\mathrm{V}$ \\
\hline Hymenocallisspecoisa & Bakung & $\mathrm{V}$ & $\mathrm{V}$ & & $\mathrm{V}$ \\
\hline Ixora sp & Soka Merah & $\mathrm{V}$ & & & $\mathrm{V}$ \\
\hline Jatropha pandurifolia & Batavia & $\mathrm{V}$ & $\mathrm{V}$ & & $\mathrm{V}$ \\
\hline Nerium oleander & Oleander & & $\mathrm{V}$ & & \\
\hline Mussaenda $\mathrm{sp}$ & Nusa Indah & $\mathrm{V}$ & $\mathrm{V}$ & & $\mathrm{V}$ \\
\hline Rhapis exelsa & Palem Wregu & & & & $\mathrm{V}$ \\
\hline Rossa $\mathrm{sp}$ & Mawar & & $\mathrm{V}$ & & $\mathrm{V}$ \\
\hline Sansieviera $\mathrm{sp}$ & Lidah Mertua & $\mathrm{V}$ & & & $\mathrm{V}$ \\
\hline Zephyranthes sp & Bawang Brojol & $\mathrm{V}$ & $\mathrm{V}$ & $\mathrm{V}$ & $\mathrm{V}$ \\
\hline \multicolumn{6}{|l|}{ Penutup Tanah } \\
\hline Ananas $\mathrm{sp}$ & Nenas Hias & & $\mathrm{V}$ & & $\mathrm{V}$ \\
\hline Arachis pintoi & Landep & $\mathrm{V}$ & $\mathrm{V}$ & & $\mathrm{V}$ \\
\hline Catharanthus roseus & Tapak Dara & & $\mathrm{V}$ & & \\
\hline Chlorophytum sp & \begin{tabular}{|l} 
Lili Paris \\
\end{tabular} & $\mathrm{V}$ & $\mathrm{V}$ & & $\mathrm{V}$ \\
\hline Coleus sp & $\begin{array}{l}\text { Bayam- } \\
\text { bayaman }\end{array}$ & & $\mathrm{V}$ & & $\mathrm{V}$ \\
\hline Cuphea sp & Taiwan Putih & $\mathrm{V}$ & $\mathrm{V}$ & & $\mathrm{V}$ \\
\hline Dianella enfisolia & Lili Brazil & $\mathrm{V}$ & $\mathrm{V}$ & & $\mathrm{V}$ \\
\hline Iresine herstii & \begin{tabular}{|l|} 
Sambang \\
Darah \\
\end{tabular} & V & $\mathrm{V}$ & V & $\mathrm{V}$ \\
\hline Iris flava & Iris & $\mathrm{V}$ & $\mathrm{V}$ & & $\mathrm{V}$ \\
\hline Lantana camara & Lantana & $\mathrm{V}$ & $\mathrm{V}$ & & $\mathrm{V}$ \\
\hline Ophiopogon intermedius & Lili putih & $\mathrm{V}$ & $\mathrm{V}$ & $\mathrm{V}$ & $\mathrm{V}$ \\
\hline Portulaca sp & Sutra Bombay & $\mathrm{V}$ & $\mathrm{V}$ & $\mathrm{V}$ & $\mathrm{V}$ \\
\hline Rhoe discolour & Adam Hawa & $\mathrm{V}$ & & & $\mathrm{V}$ \\
\hline Ruellia malacosperma & $\begin{array}{l}\text { Ruelia bunga } \\
\text { ungu }\end{array}$ & & $\mathrm{V}$ & & $\mathrm{V}$ \\
\hline \multicolumn{6}{|l|}{ Tanaman Merambat } \\
\hline Allamanda cathartica & Alamanda & & $\mathrm{V}$ & & \\
\hline \multicolumn{6}{|l|}{ Rumput } \\
\hline Axonopus compressus & \begin{tabular}{|l|} 
Rumput \\
Paetan \\
\end{tabular} & $\mathrm{V}$ & $\mathrm{V}$ & & $\mathrm{V}$ \\
\hline Cynodon dactylon & $\begin{array}{l}\text { Rumput } \\
\text { bermuda }\end{array}$ & & $\mathrm{V}$ & $\mathrm{V}$ & \\
\hline
\end{tabular}

Sumber : Dinas Pertamanan Kota Pekanbaru dan Pengamatan 


\section{B. Elemen Penunjang}

Pada lanskap jalan terdapat juga elemen selain tanaman yang menjadi pembentuk lanskap jalan. Elemen penunjang tersebut berupa kelengkapan jalan (street furniture).

Elemen penunjang pada Jalan Sudirman seperti halte bus, tugu selamat datang, saluran drainase, pagar pembatas, jembatan penyebrangan, lampu jalan, papan informasi, marka jalan. Elemen penunjang pada Jalan Gajah Mada yaitu lampu jalan, marka jalan, tempat sampah, saluran drainase. Elemen penunjang pada Jalan Cut Nyak Dien yaitu marka jalan, lampu jalan, saluran drainase. Elemen penujang pada Jalan Diponegoro yaitu papan informasi, marka jalan, lampu jalan, saluran drainase.

Tabel 8. Elemen Penunjang Pada Lokasi Penelitian

\begin{tabular}{|l|l|}
\hline \multicolumn{1}{|c|}{ Lokasi } & \multicolumn{1}{|c|}{ Elemen Penunjang } \\
\hline Jalan Sudirman & $\begin{array}{l}\text { Halte, tugu selamat datang, saluran drainase, patung, jembatan } \\
\text { penyebrangan, pagar pembatas, lampu jalan, papan informasi, marka } \\
\text { jalan, lampu lalu lintas }\end{array}$ \\
\hline Jalan Cut Nyak Dien & Saluran drainase, pos penjaga, marka jalan, lampu jalan \\
\hline Jalan Gajah Mada & $\begin{array}{l}\text { Saluran drainase, marka jalan, lampu jalan, lampu lalu lintas, tempat } \\
\text { sampah }\end{array}$ \\
\hline Jalan Diponegoro & Saluran drainase, marka jalan, lampu jalan, lampu lalu lintas, \\
\hline
\end{tabular}

\section{Disain penanaman}

\section{A. Jalan Sudirman}

Jalan Sudirman merupakan jalan utama di Pekanbaru dan merupakan jalan terpanjang. Jalan ini umumnya memiliki pohon-pohon yang sudah tua. Pohon jenis angsana merupakan pohon yang mendominasi di sepanjang median jalan Sudirman. Pohon ini ada ditanam secara massal ataupun pada segmen tertentu pohon ini dikombinasikan dengan perdu/semak dan groundcover. Pada segmen di depan pelabuhan Pelita Pantai median jalan juga dilengkapi dengan planting box diletakkan diantara jejeran pohon angsana. Tajuk- tajuk pohon angsana saling bersinggungan sepanjang Jalan Sudirman. Tidak semua median yang ditanami pohon angsana, pada segmen median Jalan Sudirman di depan purna MTQ. Median jalan ini didominasi dengan penanaman palem dikombinasikan dengan perdu/semak dan groundcover. Pada segmen jalan di depan Kantor Kehutanan 
terdapat kombinasi bintaro dan perdu serta groundcover. Terdapat juga segmen jalan yang mediannya didominasi perdu/semak yang ditanam berpola (pola lingkaran dan persegi) yaitu pada segmen di depan kantor gubernur.

Pada kedua sisi Jalan Sudirman didominasi jejeran pohon mahoni. Pada segmen menuju bandara udara Sultan Syarif Qasim II terdapat jejeran pohon kelapa sawit di kedua sisi jalan. Kedua sisi jalan sudirman tidak seluruhnya ditanami pohon. Pada segmen jalan di depan Kantor Gubernur terdapat planting box ditanami mawar dan cemara udang. Pada sisi jalan ini juga ditanami pohon cemara lilin.

B. Jalan Cut Nyak Dien

Jalan Cut Nyak Dien merupakan jalan yang terdapat pada komplek perkantoran. Jalan Cut Nyak Dien pada tiap segmennya memiliki desain penanaman yang berbeda. Terdapat dua segmen jalan yang memiliki median jalan. Pada median jalan di samping Balai Dang Merdu didominasi pohon palem dikombinasikan dengan perdu dan groundcover. Pada segmen di samping perpustakaan dominasi palem, kembang merak, cassia glauca dan perdu. Pada kedua sisi jalan ditanami dengan pohon mahoni, tanjung dan palem. Pada tiap segmen memiliki perbedaan penanaman jenis tanaman pada kedua sisi jalan. Pada Jalan Cut Nyak Dien tidak terdapat satu jenis pohon yang secara umum mendominasi.

C. Jalan Gajah Mada

Jalan Gajah Mada seperti koridor jalan yang menghubungkan kantor gubernur dengan rumah dinas gubernur. Jalan Gajah Mada didominasi penanaman pohon mahoni di kedua sisi jalan dan penempatan planting box berbentuk lingkaran yang ditanami mawar dan pangkas kuning dipangkas bulat. Terdapat median jalan yang ditanami cemara udang dikombinasikan dengan perdu dan groundcover yang ditanam berpola membentuk taman pada median jalan.

D. Jalan Diponegoro

Jalan Diponegoro didominasi pohon tanjung sebagai tanaman tepi jalan dan bintaro serta palem sebagai tanaman median jalan. Pada median pohon bintaro dan palem ditanam berselang-seling dikombinasikan dengan perdu dan 
groundcover. Median ditanami kombinasi pohon, perdu dan groundcover yang dibentuk pola-pola lingkaran dan persegi.

Tabel 9. Pembagian Segmen Jalan, Lokasi, dan Komposisi tanaman

\begin{tabular}{|c|c|c|c|c|}
\hline Jalan & Segmen & $\begin{array}{l}\text { Panjang } \\
\text { Segmen } \\
(\mathrm{m})\end{array}$ & Lokasi & Komposisi dan Jenis Tanaman \\
\hline \multirow[t]{4}{*}{$\begin{array}{l}\text { Cut Nyak } \\
\text { Dien }\end{array}$} & 1 & 250 & $\begin{array}{l}\text { Samping Balai Dang Merdu, } \\
\text { disamping kantor gubernur. } \\
\text { Di depan dinas pendidikan }\end{array}$ & $\begin{array}{l}\text { Massal sejenis : pohon mahoni } \\
\text { Kelompok campuran : palem putri, } \\
\text { cassia glauca, palem ekor tupai, } \\
\text { cemara udang, rumput paitan, } \\
\text { bakung, teh-tehan, drasena, bayam- } \\
\text { bayaman, agave }\end{array}$ \\
\hline & 2 & 250 & $\begin{array}{l}\text { Samping dinas pendidikan, } \\
\text { belakang kantor gubernur, } \\
\text { dinas pekerjaan umum } \\
\text { propinsi }\end{array}$ & $\begin{array}{l}\text { Kelompok campuran : pohon } \\
\text { mahoni, palem raja } \\
\text { Massal sejenis : soka }\end{array}$ \\
\hline & 3 & 200 & $\begin{array}{l}\text { Samping kantor gubernur, } \\
\text { perpustakaan daerah } \\
\text { (terdapat median jalan) }\end{array}$ & $\begin{array}{l}\text { Massal sejenis : pohon mahoni } \\
\text { Kelompok campuran : cemara lilin, } \\
\text { soka, palem putri, cassia glauca, } \\
\text { kembang merak, bakung, } \\
\text { Soliter : glodogan tiang }\end{array}$ \\
\hline & 4 & 450 & $\begin{array}{l}\text { Samping bank indonesia, } \\
\text { dinas tata ruang, SD, dinas } \\
\text { kehutanan, dinas perkebunan } \\
\text { dan pertanian }\end{array}$ & $\begin{array}{l}\text { Kelompok campuran : pohon } \\
\text { mahoni, tanjung, matoa } \\
\text { Massal sejenis : pohon tanjung }\end{array}$ \\
\hline \multirow[t]{6}{*}{ Sudirman } & 1 & 400 & $\begin{array}{l}\text { Pelabuhan, pelita pantai, } \\
\text { kantor bea cukai, pasar buah } \\
\text { pekanbaru (terdapat median } \\
\text { jalan) }\end{array}$ & $\begin{array}{l}\text { Kelompok campuran : } \text { pohon } \\
\text { angsana, bakung, bunga } \\
\text { bambu } \\
\text { Soliter : krei paying }\end{array}$ \\
\hline & 2 & 1175 & $\begin{array}{l}\text { Pasar buah pekanbaru, Bank } \\
\text { Mandiri, Mall Pekanbaru, } \\
\text { kantor Telkom }\end{array}$ & $\begin{array}{l}\text { Massal sejenis : pohon angsana } \\
\text { Kelompok : pangkas kuning, } \\
\text { bakung, drasena, rumput }\end{array}$ \\
\hline & 3 & 575 & $\begin{array}{l}\text { Kantor Telkom, Polda Riau, } \\
\text { Bundaran tugu pesawat } \\
\text { terbang }\end{array}$ & $\begin{array}{l}\text { Massal sejenis : pohon mahoni } \\
\text { Kelompok campuran : pohon } \\
\text { angsana, lili paris, alamanda, } \\
\text { bakung, palem merah, ruelia, } \\
\text { mawar, Taiwan beauty, kacang- } \\
\text { kacangan, bayam-bayaman, teh- } \\
\text { tehan } \\
\text { Soliter : pinus }\end{array}$ \\
\hline & 4 & 500 & $\begin{array}{l}\text { Kantor gubernur, kantor } \\
\text { kejaksaan, kantor walikota, } \\
\text { alam mayang, bundaran air } \\
\text { mancur }\end{array}$ & $\begin{array}{l}\text { Massal sejenis : pohon mahoni, } \\
\text { bintaro } \\
\text { Kelompok campuran : angsana, } \\
\text { tanjung, cemara udang, agave, } \\
\text { mawar, ruelia, nusa indah, bintaro, } \\
\text { rumput paitan, rambutan, soka, teh- } \\
\text { tehan, bawang-bawangan, sutra } \\
\text { bombay, tapak dara, adam hawa }\end{array}$ \\
\hline & 5 & 350 & $\begin{array}{l}\text { Kantor } \\
\text { garamedia }\end{array}$ & $\begin{array}{l}\text { Massal sejenis : pohon mahoni } \\
\text { Kelompok campuran : bintaro, } \\
\text { bawang-bawangan, ruelia, soka, } \\
\text { tanjung, rumput paitan, bakung, } \\
\text { bougenvil }\end{array}$ \\
\hline & 6 & 1450 & Gramedia, pasar dupa & $\begin{array}{l}\text { Massal sejenis : pohon mahoni, } \\
\text { angsana } \\
\text { Kelompok campuran : pohon } \\
\text { angsana, bawang-bawangan, } \\
\text { bayam merah, lili paris, teh-tehan, } \\
\text { lantana, sutra bombay, }\end{array}$ \\
\hline
\end{tabular}


Tabel 9. ( Lanjutan)

\begin{tabular}{|c|c|c|c|c|}
\hline \multirow[t]{3}{*}{ Jalan } & Segmen & $\begin{array}{l}\text { Panjang } \\
\text { Segmen } \\
(\mathrm{m})\end{array}$ & Lokasi & Komposisi dan Jenis Tanaman \\
\hline & 7 & 3200 & Pasar dupa, & $\begin{array}{l}\text { Massal sejenis : pohon mahoni } \\
\text { Kelompok campuran : palem raja, } \\
\text { agave, bawang-bawangan, bayam } \\
\text { merah, ruelia, nusa indah, bakung, } \\
\text { mawar, oleander, lantana, lili paris, } \\
\text { rumput paitan }\end{array}$ \\
\hline & 8 & 600 & $\begin{array}{l}\text { Simpang tiga jalan nasution, } \\
\text { bundaran bandara Sultan } \\
\text { Syarif Qasim II }\end{array}$ & $\begin{array}{l}\text { Massal sejenis : kelapa sawit, } \\
\text { pohon mahoni } \\
\text { Kelompok campuran : bunga } \\
\text { merak, palem merah, cassia glauca, } \\
\text { soka, bakung, nusa indah, teh- } \\
\text { tehan, Taiwan beauty, rumput } \\
\text { paitan } \\
\text { Soliter : pinus }\end{array}$ \\
\hline Gajah Mada & 1 & 550 & $\begin{array}{l}\text { kantor KPU, Bappeda, } \\
\text { Perumahan dinas, Polda Riau }\end{array}$ & $\begin{array}{l}\text { Massal sejenis : pohon mahoni } \\
\text { Kelompok campuran : cemara } \\
\text { udang, sutra Bombay, bawang- } \\
\text { bawangan, rumput jepang, teh- } \\
\text { tehan, agave, kacangan, pisang } \\
\text { hias, ruelia, sambang darah, ruelia }\end{array}$ \\
\hline \multirow[t]{5}{*}{ Diponegoro } & 1 & 650 & $\begin{array}{l}\text { Kampus } \text { UNRI kedokteran, } \\
\text { samping RSUD Arifin } \\
\text { Ahmad, perumahan, didepan } \\
\text { jalan petala bumi }\end{array}$ & $\begin{array}{l}\text { Massal sejenis : pohon tanjung, } \\
\text { pohon mahoni } \\
\text { Kelompok campuran : bunga } \\
\text { merak, palem merah, palem ekor } \\
\text { tupai, kamboja, tanjung, bawang- } \\
\text { bawangan, teh-tehan, soka, mawar, } \\
\text { bintaro, palem wregu, }\end{array}$ \\
\hline & & & & $\begin{array}{l}\text { bakung, pangkas kuning, rumput } \\
\text { paitan } \\
\text { Soliter : akasia, beringin, bambu } \\
\text { jepang }\end{array}$ \\
\hline & 2 & 400 & $\begin{array}{l}\text { Rumah gubernur, Gor } \\
\text { tribuana,balai adat }\end{array}$ & $\begin{array}{l}\text { Massal sejenis : pohon mahoni, } \\
\text { bougenvil } \\
\text { Kelompok campuran : bunga } \\
\text { merak, palem merah, palem ekor } \\
\text { tupai, kamboja, rumput, bawang- } \\
\text { bawangan, teh-tehan, soka, mawar, } \\
\text { bintaro, bunga merak, teh-tehan, } \\
\text { pisang hias, sambaing darah }\end{array}$ \\
\hline & 3 & 350 & $\begin{array}{l}\text { Balai adat, di depan jalan } \\
\text { ronggowarsito, depan taman } \\
\text { kota, hotel arya duta }\end{array}$ & $\begin{array}{l}\text { Massal sejenis : pohon mahoni dan } \\
\text { pohon glodogan bulat } \\
\text { Kelompok campuran : bunga } \\
\text { merak, palem merah, palem ekor } \\
\text { tupai, kamboja, rumput paitan, } \\
\text { bawang-bawangan, teh-tehan, soka, } \\
\text { mawar, bintaro, tanjung, pisang } \\
\text { hias, sambaing darah }\end{array}$ \\
\hline & 4 & 500 & $\begin{array}{l}\text { Kantor dharma wanita, MAN } \\
\text { model, radio aditya, }\end{array}$ & $\begin{array}{l}\text { Massalsejenis : pohon mahoni. } \\
\text { tanjung } \\
\text { Kelompok campuran : bunga } \\
\text { merak, palem merah, palem ekor } \\
\text { tupai, kamboja, tanjung, rumput, } \\
\text { bawang-bawangan, teh-tehan, soka, } \\
\text { mawar, bintaro } \\
\text { Soliter : akasia }\end{array}$ \\
\hline
\end{tabular}




\section{Tata Guna Lahan}

Pada Jalan Sudirman, tata guna lahannya meliputi fasilitas pendidikan, fasilitas pemerintahan, fasilitas kesehatan, area perdagangan dan jasa, ruang terbuka hijau, Tata guna lahan Jalan Diponegoro yaitu fasilitas pendidikan, fasilitas pemerintahan, fasilitas kesehatan, fasilitas umum dan sosial, ruang terbuka hijau, pemukiman, dan fasilitas olahraga. Tata guna lahan Jalan Gajah Mada yaitu area pemerintahan, dan pemukiman. Tata guna lahan Jalan Cut Nyak Dien berupa ruang terbuka hijau, fasilitas pemerintahan, dan fasilitas pendidikan.

\section{Sosial Ekonomi}

Pada keempat jalan lokasi penelitian terdapat fasilitas-fasilitas yang mendukung kegiatan ekonomi dan sosial. Fasillitas dan aktifitas yang terdapat pada keempat jalan tersebut antara lain dapat dilihat pada Tabel 10.

Tabel 10. Fasilitas dan Aktifitas Ekonomi

\begin{tabular}{|l|l|l|l|}
\hline No & \multicolumn{1}{|c|}{ Lokasi } & \multicolumn{1}{|c|}{ Fasilitas Sosial -Ekonomi } & \multicolumn{1}{c|}{ Aktifitas } \\
\hline 1 & Jalan Sudirman & $\begin{array}{l}\text { SPBU, Kantor Pemerintahan, } \\
\text { Hotel, Rumah sakit, Toko-toko, } \\
\text { Lembaga Pendidikan, Kantor } \\
\text { Swasta, Bank }\end{array}$ & $\begin{array}{l}\text { Sirkulasi, } \\
\text { belajar, } \\
\text { (angkutan kota), perkantoran, } \\
\text { pengisian bahan bakar }\end{array}$ \\
\hline 2 & Jalan Diponegoro & $\begin{array}{l}\text { Perumahan, Kantor Pemerintahan, } \\
\text { Lembaga Pendidikan, Taman Kota, } \\
\text { Hotel }\end{array}$ & $\begin{array}{l}\text { Perkantoran, belajar, rekreasi, } \\
\text { sirkulasi, }\end{array}$ \\
\hline 3 & Jalan Gajah Mada & Kantor Pemerintahan, Perumahan & Sirkulasi, perkantoran, \\
\hline 4 & $\begin{array}{l}\text { Jalan Cut Nyak } \\
\text { Dien }\end{array}$ & $\begin{array}{l}\text { Kantor pemerintahan, Sekolah } \\
\text { dasar, Taman kota }\end{array}$ & $\begin{array}{l}\text { Sirkulasi, perkantoran, } \\
\text { belajar, rekreasi, }\end{array}$ \\
\hline
\end{tabular}

\section{Pemeliharaan dan Perawatan Jalur Hijau}

Pemeliharaan jalur hijau jalan dilakukan oleh Dinas Kebersihan dan Pertamanan Kota Pekanbaru. Pemeliharaan taman (termasuk jalur hijau jalan) menggunakan tenaga kerja harian lepas sebanyak 173 orang yang terdiri dari : mandor 4 orang, teknis 1 orang, supir penyiraman 8 orang, buruh penyiraman 16 orang, supir operasional 1 orang, buruh taman 116 orang, buruh pemotong rumput 25 orang dan hedge trimmers 2 orang. Mobil operasional pemeliharaan yang digunakan terdiri dari : mobil penyiraman 4 unit (bekerja 2 shift), mobil L 3001 unit, dan mobil pick up operasional 1 unit. 
Tindakan yang dilakukan sehubungan dengan kegiatan perawatan tanaman antara lain : penyiraman, pemotongan rumput, pemberantasan hama, pemupukan, pemangkasan.

\section{Penyiraman}

Kebutuhan air yang cukup besar sehingga Dinas Pertamanan Kota Pekanbaru menggunakan mobil khusus yang memiliki kapasitas penyiraman air amat besar. Penyiraman menggunakan selang panjang sebagai saluran air dari tangki mobil. Tidak semua tanaman tahan terhadap siraman keras dari jarak jauh sehingga tanaman yang berdaun lemah, berbunga mudah rontok, dan berbatang mudah patah disiram dengan hati-hati. Pohon yang disiram adalah pohon yang masih kecil dan baru ditanam, sedangkan pohon yang sudah tumbuh besar disiram pada waktu musim kemarau saja agar pohon dapat bertahan pada musim kemarau. Penyiraman dilakukan 2 kali sehari yaitu pada pagi hari dan sore hari. Intensitas penyiraman pada musim kemarau dilebihkan menjadi 3 kali sehari. Pada musim kemarau tanaman akan gersang dan kering sehingga dibutuhkan penyiraman untuk menjaga kesegaran tanaman.

\section{Pemotongan Rumput}

Rumput yang sudah panjang segera dipotong atau dipangkas agar jangan sampai berbaur dengan rumput liar. Pemberantasan rumput liar dengan hebisida dihindari sebab ditakutkan semprotan herbisida terkena ke tanaman lain dan dapat ikut mati.

3. Pemberantasan Hama Penyakit

Gabungan beberapa jenis tanaman biasanya memungkinkan beberapa jenis hama penyakit yang berlainan menyerang tanaman. Hama yang biasanya menyerang satu jenis tanaman tertentu dapat menyerang tanaman lain didekatnya. Jenis hama dan penyakit yang bisa menyerang tanaman yaitu ; kutu daun, ulat, bekicot, rayap, dan serangga lainnya. Penyemprotan untuk tanaman yang sudah terserang penyakit dilakukan 1-2 kali seminggu. Penyemprotan di saat matahari terik dihindari agar daun tanaman tidak terbakar.

4. Pemupukan 
Pupuk penting untuk menunjang kebutuhan unsur hara tanaman agar tanaman tumbuh baik. Pupuk yang digunakan adalah pupuk kandang yang baik bagi pertumbuhan tanaman, menggemburkan tanah, dan tidak meninggalkan residu kimia atau pengaruh kimia tertentu bagi tanaman. Pupuk kandang biasa diberikan sebanyak 2-4 kg/m². Kotoran binatang yang baik untuk digunakan sebagai pupuk kandang yaitu sapi, kerbau, ayam dan kuda. Penggunaan pupuk anorganik dilakukan untuk mencukupi kebutuhan unsur hara tanah. Kandungan unsur kimia pupuk anorganik cukup tinggi sehingga sering digunakan dalam jumlah besar. Jenis pupuk anoraganik yang digunakan adalah jenis pupuk padat atau pupuk cair. Pemberian pupuk pada tanaman dilakukan dengan cara; dipendam dalam lubang, disebar dalam tanah, ditabur dalam lajur, disemprotkan lewat daun.

\section{Pemangkasan}

Tanaman memiliki jadwal pemangkasan yang berbeda-beda. Ada tanaman yang membutuhkan pemangkasan secara rutin dengan selang waktu yang cepat dan ada yang membutuhkan pemangkasan dengan selang waktu agak lama. Perdu dan semak membutuhkan periode pemangkasan yang cepat, sedangkan pohon periodenya agak lama. Keragaman bentuk tanaman yang dibentuk khusus dengan cara pemangkasan akan memperindah penampilan tanaman. Alat pangkas yang digunakan biasanya gunting pangkas. Gunting pangkas digunakan untuk memangkas dan membentuk tanaman rendah. Tanaman yang baru dipangkas akan disiram dan diberikan pupuk agar cepat pulih dan tumbuh subur.

Pohon membutuhkan pemangkasan bila sudah terlalu rimbun atau pertumbuhan tajuknya kurang terarah. Pada musim hujan merupakan saat tepat untuk pemangkasan pohon karena tanaman dapat cepat pulih kembali. Pada musim kemarau tidak dianjurkan melakukan pemangkasan karena hujan jarang turun, sinar matahari begitu terik, dan tanaman dapat mengalami stress dan pertumbuhannya terganggu. Tujuan pemangkasan antara lain; menggurangi tinggi tanaman dan memotong cabang yang terlalu panjang, menggurangi kelembapan tanaman untuk tanaman yang terlalu rimbun, membuang cabang yang menganggu 
pemandangan, mengganti cabang tua, membuang cabang yang terkena hama penyakit, memotong cabang mati atau patah, membentuk tajuk menarik. Pemangkasan pohon dilaksanakan setiap hari mulai jam 07.00 wib s/d 12.00 wib. Peralatan yang digunakan yaitu gergaji, chainsaw, parang dan lainnya. 


\section{Penilaian Aspek Fungsi Tanaman Lanskap Jalan}

Penilaian mencakup pada 7 aspek fungsi yaitu fungsi pengarah, pembatas visual, peneduh, kontrol kesilauan, kontrol bunyi, kontrol polusi dan pemberi identitas. Tiap fungsi memiliki kriteria penilaian tersendiri. Setelah dilakukan penilaian 7 aspek fungsi pada tiap segmen jalan maka nilai akhir dimasukkan kedalam 4 kategori yaitu, 1. kategori sangat baik, 2. kategori baik, 3. kategori sedang, dan 4. kategori buruk. Hasil penilaian 7 aspek fungsi dideskripsikan persegmen pada tiap jalan lokasi penelitian.

\section{Fungsi Pengarah}

Kriteria tanaman berfungsi sebagai pengarah yaitu perdu dengan ketinggian 3-6 $\mathrm{m}$ dan pohon dengan ketinggian $/ 6 \mathrm{~m}$, ditanam secara massal atau sejenis, jarak tanam rapat dengan interval teratur, berkesinambungan, berkesan rapi dan memudahkan orientasi, dan bertajuk kolumnar atau batang jelas. Penilaian tanaman sebagai fungsi pengarah dapat dilihat pada Tabel 11.

Tabel 11. Penilaian Fungsi Pengarah

\begin{tabular}{|c|c|c|c|c|c|c|c|c|c|}
\hline \multirow[t]{2}{*}{ Nama Jalan } & \multirow[t]{2}{*}{ Segmen } & \multicolumn{6}{|c|}{ Kriteria Penilaian } & \multirow{2}{*}{$\begin{array}{l}\text { Skor } \\
(\%)\end{array}$} & \multirow[t]{2}{*}{ Kategori } \\
\hline & & 1 & 2 & 3 & 4 & 5 & 6 & & \\
\hline \multirow{4}{*}{$\begin{array}{ll}\text { Cut } & \text { Nyak } \\
\text { Dien } & \end{array}$} & 1 & 3 & 2 & 2 & 3 & 3 & 3 & 66,7 & Baik \\
\hline & 2 & 3 & 3 & 3 & 3 & 3 & 4 & 79,2 & Baik \\
\hline & 3 & 3 & 3 & 3 & 3 & 3 & 3 & 75 & Baik \\
\hline & 4 & 3 & 4 & 3 & 3 & 3 & 4 & 83,3 & $\begin{array}{l}\text { Sangat } \\
\text { Baik }\end{array}$ \\
\hline \multicolumn{8}{|c|}{ Total Rata-rata } & 76 & Baik \\
\hline \multirow[t]{8}{*}{ Sudirman } & 1 & 3 & 3 & 3 & 3 & 4 & 4 & 83,3 & $\begin{array}{l}\text { Sangat } \\
\text { Baik }\end{array}$ \\
\hline & 2 & 3 & 4 & 4 & 3 & 4 & 4 & 91,7 & $\begin{array}{l}\text { Sangat } \\
\text { Baik }\end{array}$ \\
\hline & 3 & 3 & 4 & 4 & 2 & 4 & 4 & 87,5 & $\begin{array}{l}\text { Sangat } \\
\text { Baik }\end{array}$ \\
\hline & 4 & 3 & 3 & 2 & 2 & 2 & 2 & 58,3 & Sedang \\
\hline & 5 & 3 & 3 & 3 & 2 & 3 & 3 & 70,8 & Baik \\
\hline & 6 & 2 & 4 & 4 & 4 & 4 & 3 & 87,5 & $\begin{array}{l}\text { Sangat } \\
\text { Baik }\end{array}$ \\
\hline & 7 & 3 & 3 & 3 & 3 & 4 & 3 & 79,2 & Baik \\
\hline & 8 & 3 & 4 & 3 & 3 & 4 & 3 & 83,3 & $\begin{array}{l}\text { Sangat } \\
\text { Baik }\end{array}$ \\
\hline \multicolumn{8}{|c|}{ Total Rata-rata } & 80,2 & $\begin{array}{l}\text { Sangat } \\
\text { Baik }\end{array}$ \\
\hline Gajah Mada & 1 & 3 & 3 & 3 & 3 & 3 & 3 & 75 & Baik \\
\hline \multicolumn{8}{|c|}{ Total Rata-rata } & 75 & Baik \\
\hline Diponegoro & 1 & 3 & 3 & 3 & 3 & 3 & 3 & 75 & Baik \\
\hline
\end{tabular}


Tabel 11. (Lanjutan)

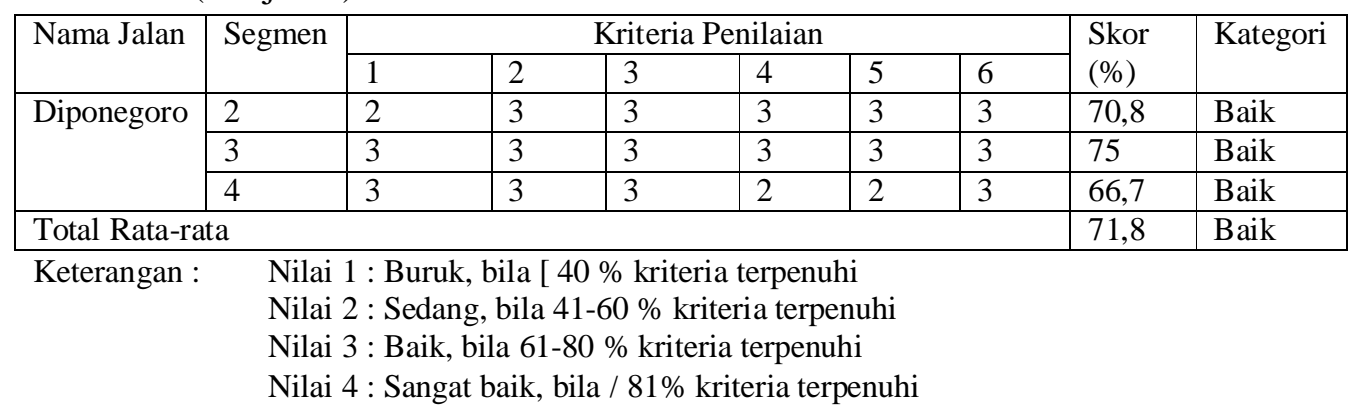

\section{Jalan Cut Nyak Dien}

Segmen 1, penilaian pada segmen ini menunjukkan $66,7 \%$ dari 6 kriteria penilaian terpenuhi. Hasil ini menunjukkan bahwa segmen ini termasuk kedalam kategori baik. Fungsi pengarah pada jalan ini dapat terlihat pada jejeran pohon mahoni yang ditanam sepanjang kiri kanan jalan. Pohon mahoni yang ditanam dengan interval tertentu dan berkesinambungan menciptakan keadaan rapi dan memudahkan orientasi. Pada Gambar 19 dapat dilihat contoh gambaran pohon fungsi pengarah pada Jalan Cut Nyak Dien segmen 1.

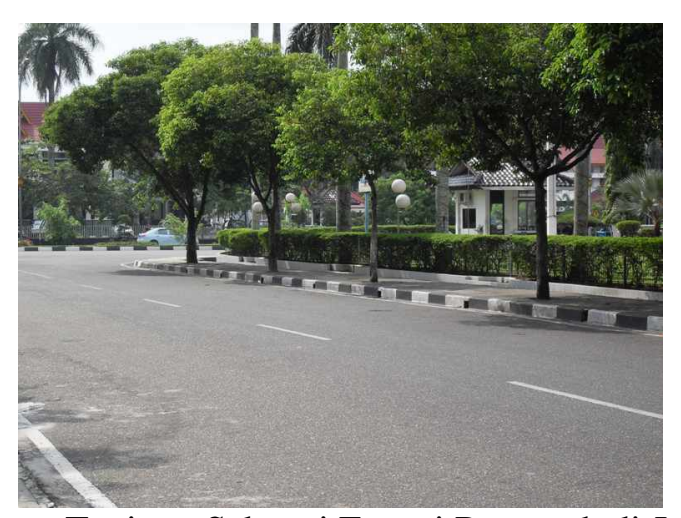

Gambar 19. Deretan Tanjung Sebagai Fungsi Pengarah di Jalan Cut Nyak Dien

Segmen 2, penilaian pada segmen ini menunjukkan 79,2\% dari 6 kriteria penilaian terpenuhi. Hasil ini menunjukkan bahwa segmen ini termasuk kedalam kategori baik. Penanaman palem raja diselingi dengan penanaman pohon mahoni memudahkan orientasi. Jarak tanam palem dan mahoni yang rapat, penanaman dengan interval teratur dan berkesinambungan menghasilkan tatanan yang rapi dan mengarahkan pandangan. 
Segmen 3, penilaian pada segmen ini menunjukkan $75 \%$ dari 6 kriteria penilaian terpenuhi. Hasil ini menunjukkan bahwa segmen ini termasuk kedalam kategori baik. Pada trotoar di samping kantor gubernur ditanami cemara lilin dan kombinasi Phyllantus niruri dan diselinggi dengan pohon mahoni, penataan ini memberikan kemudahan orientasi. Penanamannya yang rapat dengan interval teratur serta berkesinambungan sehingga terlihat rapi dan mengarahkan. Pada trotoar di samping perpustakaan Soeman HS ditanami pohon mahoni dengan interval teratur, jarah tanam agak berjauhan tetapi berkesinambungan sehingga masih bisa memudahkan orientasi.

Segmen 4, penilaian pada segmen ini menunjukkan 83,3\% dari 6 kriteria terpenuhi. Ruas jalan ini ditanami oleh pohon tanjung yang ditanam dengan jarak rapat dan interval tertentu sehingga terkesan rapi, khususnya pada segmen di samping kantor BI dan kantor Kehutanan. Penanaman pada kiri-kanan jalan tampak kurang rapi disebabkan penanaman pohon tepi jalan dengan interval teratur tetapi tidak berkesinambungan dan terdapat bermacam-macam pohon yang ditanam seperti matoa, tanjung, mahoni, glodogan. Sedangkan pada sisi tepi jalan yang lain pohon yang ditanam berupa tanjung dan mahoni.

\section{Jalan Sudirman}

Segmen 1, penilaian pada segmen ini 83,3\% dari 6 kriteria terpenuhi dan termasuk kategori sangat baik. Hal ini menunjukkan bahwa tata hijaunya telah memenuhi fungsi pengarah. Pada segmen jalan ini jajaran pohon Angsana yang ditanam rapat di median jalan dan memudahkan orientasi pengemudi. Pohon tersebut ditanam secara massal dengan interval teratur dan berkesinambungan sehingga berkesan rapi. Terdapat planting box diantara pohon angsana yang ditanami perdu dengan ketinggian kurang lebih $3 \mathrm{~m}$. Peletakan planting box secara berkesinambungan memberikan kesan rapi dan mengarahkan.

Segmen 2, penilaian pada segmen ini $91,7 \%$ dari 6 kriteria terpenuhi dan termasuk kategori sangat baik. pada segmen ini tata hijau berfungsi sangat baik sebagai pengarah. Pada segmen ini jejeran pohon angsana ditanam dengan jarak tanam rapat, interval teratur dan berkesinambungan sehingga berkesan rapi. Sepanjang segmen ini tajuk pohon angsana saling bersinggungan dan batang jelas. 
Segmen 3, penilaian pada segmen ini $87,5 \%$ dari 6 kriteria terpenuhi dan termasuk kategori sangat baik. Pada median jalan ditanami pohon angsana dengan tajuk lebar dan saling bersinggungan dikombinasikan dengan penutup tanah. Pohon angsana ditanam secara berjejer di sepanjang median jalan dengan jarak tanam $4 \mathrm{~m}$ dan interval yang teratur. Pohon angsana yang ditanam massal ini memberikan kesan rapi dan memudahkan dalam orientasi. Pada kedua sisi jalan ditanami pohon mahoni yang ditanam dengan jarak rapat dan interval teratur.

Segmen 4, penilaian pada segmen ini 58,3\% dari 6 kriteria terpenuhi dan termasuk kategori sedang. Pada segmen ini fungsi pengarah kurang terbentuk dari tatanan tanaman di sepanjang jalur hijau jalan. Pada median jalan pohon angsana ditanam dengan jarak yang berjauhan dan umumnya masih berupa tanaman muda. Median jalan ditanami cemara udang dikombinasikan dengan perdu dan penutup tanah yang dibentuk berpola lingkaran dan persegi. Pola-pola ini diletakkan secara berkesinambungan dengan interval teratur. Kedua sisi jalan tidak seluruhya ditanami pohon yang dapat memberikan kesan mengarahkan. Pada satu sisi jalan ditanami pohon mahoni dengan jarak tanam kurang rapat interval teratur dan berkesinambungan. Hal ini cukup memberikan kesan rapi dan kemudahan orientasi. Pada sisi jalan yang lain ditanami berbagai macam pohon seperti mahoni, cemara lilin, dan bintaro. Pada sisi jalan didepan kantor BI ditanami pohon bintaro dengan jarak tanam rapat dan interval teratur dengan tajuk saling bersinggungan sehingga terkesan rapi dan memudahkan orientasi.

Segmen 5, penilaian pada segmen ini 70,8\% dari 6 kriteria terpenuhi dan termasuk kategori baik. Pada kedua sisi jalan ditanami pohon mahoni secara massal. Pohon mahoni ditanam berbaris sepanjang jalan dengan jarak kurang lebih $3 \mathrm{~m}$ dengan interval teratur dan berkesinambungan. Hal ini menimbulkan kesan rapi dan memudahkan orientasi. Pada median jalan juga ditanami pohon bintaro yang dikombinasikan dengan perdu secara berkesinambungan. Hal ini menambah kesan rapi dan memudahkan orientasi pengguna jalan.

Segmen 6, penilain pada segmen ini 87,5\% dari 6 kriteria terpenuhi dan termasuk kategori sangat baik. Pada segmen ini adalah segmen tata hijau dengan fungsi pengarah terbaik. Kedua sisi jalan ditanami pohon mahoni dengan jarak cukup rapat dan interval teratur serta berkesinambungan. Batang terlihat jelas dan 
berkesan rapi sehingga memudahkan orientasi. Median jalan juga ditanami dengan jarak yang cukup rapat dan interval teratur dengan penanaman pohon angsana secara masssal berderet sepanjang median jalan. Tajuk angsana dan tajuk mahoni saling bersinggungan. Hal ini membentuk suatu koridor yang berkesan mengarahkan pengemudi. Ruas jalan yang memiliki fungsi pengarah terbaik yaitu di depan hotel pangeran.

Segmen 7, penilaian pada segmen ini 79,2\% dari 6 kriteria terpenuhi dan termasuk kategori baik. Segmen ini dimulai dari pasar dupa sampai simpang jalan Nasution. Pada median jalan ditanami deretan pohon palem raja yang dikombinasikan dengan perdu. Penanamn palem dengan interval teratur dan berkesinambungan memberikan kesan rapi dan memudahkan orientasi. Hal ini juga didukung dengan penanaman deretan pohon mahoni yang cukup rapat dengan tajuk saling bersinggungan pada kedua sisi jalan.

Segmen 8, penilain pada segmen ini 66,7\% dari 6 kriteria terpenuhi dan termasuk kategori baik. Pada segmen ini kedua sisi jalan ditanami deretan kelapa sawit yang ditanam sejajar dengan jarak tanam rapat dan berkesinambungan. Median jalan ditanami dengan nusa indah, bougenvil serta diselingi dengan palem merah yang dikombinasikan dengan perdu dan penutup tanah. Penanaman yang berkesinambungan memberikan kesan rapi dan memudahkan orientasi menuju pintu gerbang bandara Sultan Syarif Qasim.

\section{Jalan Gajah Mada}

Segmen 1, penilaian pada segmen ini menunjukkan 75\% dari 6 kriteria terpenuhi dan masuk ke kategori baik. Segmen ini dimulai dari depan patung pesawat terbang sampai depan patung perjuangan. Penanaman pada kedua sisi jalan berupa pohon mahoni yang ditanam massal sejenis, jarak tanam kurang lebih 3 m dengan interval tertentu, berkesinambungan, memberikan kesan rapi dan memudahkan orientasi. Penanaman mahoni secara massal sejenis ini memberikan kemudahan orientasi pada jalan yang menghubungkan Jalan Diponegoro dan Jalan Sudirman.

\section{Jalan Diponegoro}

Segmen 1, penilaian pada segmen ini menunjukkan 75\% dari 6 kriteria terpenuhi. Segmen ini dapat dikategorikan baik untuk fungsi tanaman sebagai pengarah. 
Pada segmen ini kedua sisi jalan ditanami secara massal pohon tanjung. Pohon ini ditanam dengan jarak kurang lebih $4 \mathrm{~m}$ dengan interval teratur. Tajuk pohon tanjung saling bersinggungan sehingga memberi kesan rapi dan memudahkan orientasi. Pada median jalan ditanami pohon bintaro dan palem dikombinasikan dengan perdu dan penutup tanah. Penanamannya dengan interval teratur, berkesinambungan menambah kesan rapi pada jalan dan mengarahkan pengguna jalan.

Segmen 2, penilaian pada segmen ini menunjukkan 70,8\% dari 6 kriteria terpenuhi. Segmen ini dapat dikategorikan baik untuk fungsi tanaman sebagai pengarah. Pada satu sisi jalan tidak terdapat pohon. Pada sisi jalan tersebut ditempatkan planting box yang ditanami bougenvil diletakkan dengan jarak kurang lebih $5 \mathrm{~m}$ dengan interval teratur dan berkesinambungan. Ketinggian bougenvil yang mencapai kurang lebih $3 \mathrm{~m}$ dapat memberikan kesan mengarahkan dan memudahkan orientasi. Pada sisi jalan yang lain ditanami pohon mahoni secara massal dengan interval teratur. Pohon mahoni yang ditanam massal sejenis ini memberikan kemudahan orientasi, didukung oleh penampakan batang yang jelas serta berkesinambungan dan ditanam dengan jarak kurang lebih $3 \mathrm{~m}$.

Segmen 3, penilaian pada segmen ini menunjukkan $75 \%$ dari 6 kriteria terpenuhi. Segmen ini dikategorikan baik untuk fungsi pengarah. Pada segmen ini satu sisi jalan ditanami pohon glodogan bulat dengan tajuk yang saling bersinggungan. Pohon glodogan bulat ditanam dengan jarak rapat dan interval teratur sehingga memberikan kesan rapi dan memudahkan orientasi. Pohon glodogan bulat ini ditanam secara massal sejenis berderet si sepanjang jalan. Pada sisi jalan yang lain ditanam pohon mahoni dengan jarak kurang lebih $4 \mathrm{~m}$ dengan interval teratur dan berkesinambungan.

Segmen 4, penilaian pada segmen ini menunjukkan $66,7 \%$ dari 6 kriteria terpenuhi. Segmen ini digolongkan ke dalam kategori baik sebagai fungsi pengarah. Pada kedua sisi jalan memiliki penanaman yang berbeda. Pada satu sisi jalan ditanami pohon mahoni secara massal sejenis, berkesinambungan dengan interval tertentu tetapi jarak tanam kurang rapat. Pada sisi jalan yang lain ditanami pohon tanjung, glodogan tiang dan mahoni. Jarak tanam pohon kurang lebih $3 \mathrm{~m}$, penanaman pohon kurang berkesinambungan sehingga berkesan kurang rapi. 
Departemen PU Direktorat Bina Marga (1996), menganjurkan penanaman pohon sebagai pengarah jalan memiliki bentuk tajuk columnar atau pyramidal dan pada simpangan atau persimpangan yaitu mahoni, kembang merak, glodogan tiang, bamboo, dan perdu seperti pangkas kuning. Penanaman pohon atau perdu secara massal, liniear, dan jarak penanaman yang rapat, serta kontiniu dapat memberikan orientasi kepada pengguna jalan (Vitasari, 2004). Penanaman satu jenis tanaman pada bagian jalur tertentu dapat memberikan kesan rapi dan memudahkan orientasi (Carpenter et al, 1975).

\section{Fungsi Pembatas Visual}

Kriteria tanaman berfungsi sebagai pembatas visual yaitu tanaman tinggi, perdu atau semak $\exists 1,5 \mathrm{~m}$, massa daun rapat, jarak tanam rapat $<3 \mathrm{~m}$, ditanam berbaris atau membentuk massa. Penilaian tanaman sebagai fungsi pembatas visual dapat dilihat pada Tabel 12 .

Tabel 12. Penilaian Fungsi Pembatas Visual

\begin{tabular}{|c|c|c|c|c|c|c|c|}
\hline \multirow[t]{2}{*}{ Nama Jalan } & \multirow[t]{2}{*}{ Segmen } & \multicolumn{4}{|c|}{ Kriteria Penilaian } & \multirow[t]{2}{*}{ Skor $(\%)$} & \multirow[t]{2}{*}{ Kategori } \\
\hline & & 1 & 2 & 3 & 4 & & \\
\hline \multirow{4}{*}{$\begin{array}{ll}\text { Cut } & \text { Nyak } \\
\text { Dien } & \end{array}$} & 1 & 3 & 3 & 1 & 3 & 62,5 & Baik \\
\hline & 2 & 3 & 1 & 2 & 3 & 56,3 & Sedang \\
\hline & 3 & 3 & 3 & 3 & 3 & 75 & Baik \\
\hline & 4 & 3 & 3 & 3 & 4 & 81,3 & Sangat Baik \\
\hline \multicolumn{6}{|l|}{ Total Rata-rata } & 68,7 & Baik \\
\hline \multirow[t]{8}{*}{ Sudirman } & 1 & 3 & 3 & 3 & 3 & 75 & Baik \\
\hline & 2 & 3 & 4 & 3 & 4 & 87,5 & Sangat Baik \\
\hline & 3 & 3 & 4 & 3 & 4 & 87,5 & Sangat Baik \\
\hline & 4 & 3 & 3 & 2 & 3 & 68,8 & Baik \\
\hline & 5 & 3 & 3 & 3 & 3 & 75 & Baik \\
\hline & 6 & 3 & 4 & 3 & 3 & 81,3 & Sangat Baik \\
\hline & 7 & 3 & 3 & 3 & 3 & 75 & Baik \\
\hline & 8 & 3 & 2 & 3 & 3 & 68,8 & Baik \\
\hline \multicolumn{6}{|l|}{ Total Rata-rata } & 77,4 & Baik \\
\hline Gajah Mada & 1 & 3 & 2 & 3 & 3 & 68,8 & Baik \\
\hline \multicolumn{6}{|l|}{ Total Rata-rata } & 68,8 & Baik \\
\hline \multirow[t]{4}{*}{ Diponegoro } & 1 & 3 & 3 & 3 & 3 & 75 & Baik \\
\hline & 2 & 3 & 2 & 2 & 3 & 62,5 & Baik \\
\hline & 3 & 3 & 3 & 3 & 3 & 75 & Baik \\
\hline & 4 & 3 & 3 & 3 & 3 & 75 & Baik \\
\hline \multicolumn{6}{|c|}{ Total Rata-rata } & 71,8 & Baik \\
\hline \multicolumn{8}{|c|}{$\begin{array}{ll}\text { Keterangan : } & \text { Nilai } 1: \text { Buruk, bila [ } 40 \% \text { kriteria terpenuhi } \\
& \text { Nilai } 2: \text { Sedang, bila } 41-60 \% \text { kriteria terpenuhi } \\
& \text { Nilai } 3: \text { Baik, bila } 61-80 \% \text { kriteria terpenuhi } \\
& \text { Nilai } 4: \text { Sangat baik, bila / } 81 \% \text { kriteria terpenuhi }\end{array}$} \\
\hline
\end{tabular}




\section{Jalan Cut Nyak Dien}

Segmen 1, penilaian pada segmen ini menunjukkan $62,5 \%$ dari 4 kriteria terpenuhi dan termasuk kategori baik. Pada ruas jalan ini kedua sisi jalan ditanami ditanami deretan pohon mahoni ditanam secara massal dengan jarak tanam kurang rapat. Pada median jalan ditanami deretan pohon palem dengan kombinasi perdu memiliki jarak tanam rapat. Penanaman pada median jalan ini cukup membatasi pandangan antara dua jalan yang berbeda arah.

Segmen 2, penilaian pada segmen ini menunjukkan 56,3\% dari 4 kriteria terpenuhi dan termasuk kategori sedang. Pada segmen ini kedua sisi jalan ditanami jejeran palem yang diselingi dengan pohon mahoni. Penanaman dengan jarak kurang rapat massa daun tidak rapat. Pembatas visual dari jalan menuju bangunan kurang tercipta. Pada satu sisi jalan di belakang kantor gubernur terdapat penanaman asoka secara massal dengan massa daun rapat tetapi tingginya kurang dari $1,5 \mathrm{~m}$.

Segmen 3, penilaian pada segmen ini menunjukkan 75\% dari 4 kriteria terpenuhi dan termasuk kategori baik. Pada segmen ini satu sisi jalan ditanami cemara lilin dikombinasikan penutup tanah dan juga terdapat pohon mahoni dengan tajuk saling bersinggungan. Pohon cemara lilin ditanam dengan jarak rapat membentuk massa. Kombinasi penanaman tanaman tersebut membentuk pembatas pandangan dari jalan ke bangunan. Pada sisi jalan yang lain ditanami pohon mahoni dengan jarak tanam cukup rapat dan ditanam secara massal. Median jalan ditanami palem dengan kombinasi bunga merak, cassia glauca dan juga bakung. Kombinasi tanaman ini ditanam rapat dengan interval teratur. Penanaman median jalan ini membatasi pandangan antara dua ruas jalan yang berlawanan arah.

Segmen 4, penilain pada segmen ini menunjukkan 81,3\% dari 4 kriteria terpenuhi dan termasuk kategori sangat baik. Pada segmen ini kedua sisi jalan ditanami bermacam pohon dengan jarak tanam cukup rapat dan massa daun rapat. Segmen yang terbaik yaitu pada segmen disamping kantor BI dan Kehutanan. Pada segmen ini pohon tanjung ditanam rapat berbaris dengan massa daun rapat dan jarak tanam rapat sehingga membentuk pembatas visual yang baik. Pada ruas yang lainnya sepanjang jalan ditanami pohon tanjung dan jenis pohon lain seperti pohon mahoni dan matoa dengan jarak tanam cukup rapat. 


\section{Jalan Sudirman}

Segmen 1, penilaian pada segmen jalan ini menunjukkan $75 \%$ dari 4 kriteria dan termasuk kategori baik. Pada segmen ini median jalan ditanami pohon angsana dengan jarak rapat dan diselinggi dengan peletakan planting box yang ditanami perdu/semak. Jarak planting box dengan pohon angsana rapat sehingga terbentuk pembatas pandangan antara dua jalan yang berlawanan arah. Hal ini ditambah dengan adanya pagar ditengah median jalan.

Segmen 2, penilaian pada segmen jalan ini menunjukkan 87,5\% dari 4 kriteria terpenuhi dan termasuk kategori sangat baik. Penanaman median jalan berupa pohon angsana dan rumput. Penanaman pohon dengan jarak rapat membuat tajuk pohon angsana saling bersinggungan dan massa daun rapat. Terdapat pagar pembats pada median jalan.

Segmen 3, penilaian pada segmen jalan ini menunjukkan $87,5 \%$ dari 4 kriteria terpenuhi dan termasuk kategori sangat baik. Pada segmen ini pada median jalan ditanami pohon angsana dikombinasikan dengan perdu dan penutup tanah. Angsana ditanam berbaris sepanjang median jalan membentuk massa, dengan massa daun rapat, dan jarak tanam cukup rapat. Penanaman perdu pada median sangat membantu dalam membatasi pandangan. Pada segmen ini terdapat penanaman di tepi jalan, yaitu ditanami pohon mahoni dengan jarak rapat. Tetapi penanaman mahoni masih muda sehingga penutupan tajuk belum maksimal. Hanya pada beberapa segmen jalan seperti di depan Balai Dang Merdu penutupan tajuk pohon maksimal, massa daun rapat dan membatasi pandangan dari jalan ke arah bangunan.

Segmen 4, penilaian pada segmen jalan ini menunjukkan $68,8 \%$ dari 4 kriteria dan termasuk kategori baik. Median jalan ditanami dengan cemara udang dikombinasikan dengan perdu dan penutup tanah yang ditanam membentuk pola sehingga terbentuk taman pada median jalan. Pada median jalan juga ditanami pohon tetapi jarak tanam renggang. Pembatas terbentuk dari penanaman cemara udang dan perdu yang ditanam rapat membentuk massa. Pada tepi jalan ditanami berbagai pohon. Pada tepi jalan di depan BI ditanami oleh pohon bintaro berbaris membentuk massa, tajuk bersinggungan, massa daun rapat sehingga terbentuk pembatas bangunan dengan jalan. Hal ini juga terjadi pada segmen tepi jalan di 
depan kantor gubernur ditanami cemara lilin dikombinasikan dengan penutup tanah. Peletakan cemara lilin secara berbaris, dengan massa daun rapat, jarak tanam rapat membentuk pembatas pandangan dengan jalan ke bangunan.

Segmen 5, penilain pada segmen jalan ini menunjukkan 75\% dari 4 kriteria dan termasuk kategori baik. Pada tepi jalan ditanami pohon mahoni dengan jarak rapat, berbaris, membentuk massa, memberikan batas pandangan jalan ke bangunan. Pada median jalan ditanami pohon bintaro dengan kombinasi perdu. Jarak tanam dan massa daun rapat, ditanam berbaris sepanjang median jalan memberikan batasan visual antara dua jalan yang beda arah.

Segmen 6, penilaian pada segmen jalan ini menunjukkan $81,3 \%$ dari 4 kriteria dan termasuk kategori sangat baik. Tepi jalan pada kedua sisi ditanami pohon mahoni dengan jarak tanam rapat, tajuk bersinggunan, massa daun rapat, ditanam berbaris membentuk massa dan memberi batasan pandangan dari arah jalan menuju bangunan. Pada median jalan ditanami pohon angsana dengan jarak tanam cukup rapat, massa daun padat, tajuk bersinggungan dan ditanam berbaris membentuk massa.

Segmen 7, penilaian pada segmen jalan ini menunjukkan 75\% dari 4 kriteria dan termasuk kategori baik. Pada segmen ini median jalan ditanami oleh palem raja dan perdu. Jarak tanam rapat, membentuk massa, dengan massa daun padat. Sehingga membentuk pembatas dua jalan. Pada sisi jalan ditanami pohon mahoni dengan jarak rapat, berbaris membentuk massa dan membatasi trotoar dengan badan jalan.

Segmen 8, penilaian pada segmen jalan ini menunjukkan 68,8\% dari 4 kriteria dan termasuk kategori baik. Pada segmen ini kedua sisi jalan ditanami beberapa jenis pohon seperti angsana dan kelapa sawit. Kelapa sawit ditanam dengan jarak rapat, berbaris. Pada median jalan ditanami nusa indah, bougenvil dan palem merah dikombinasikan dengan perdu. Tanaman tersebut ditanam dengan jarak rapat, massa daun padat, membentuk massa dan membatasi pandangan dua jalan.

\section{Jalan Gajah Mada}

Segmen 1, penilaian pada segmen ini menunjukkan 68,8\% dari 4 kriteria terpenuhi dan dikategorikan baik. Pada kedua sisi jalan ditanami deretan pohon 
mahoni dan juga planting box yang ditanami pangkas kuning dan mawar. Jarak tanam pohon rapat dan ditanam berbaris. Pada segmen ini tidak terdapat median jalan yang utuh, sehingga tidak ada pembatas pandangan antara dua ruas jalan yang berbeda arah.

\section{Jalan Diponegoro}

Segmen 1, penilaian pada segmen ini menunjukkan 75\% dari 4 kriteria terpenuhi dan dikategorikan baik. Penanaman pada median jalan ditanami pohon bintaro, palem putri dan palem merah yang ditanam berselang-seling dikombinasikan dengan perdu dan penutup tanah. Jarak tanam yang rapat dengan massa daun rapat serta ditanam secara massal membentuk pembatas visual antara dua jalan yang berbeda arah. Pada kedua sisi jalan ditanami pohon tanjung dengan tajuk saling bersinggungan, massa daun rapat, ditanam berbaris membentuk massa dan memiliki jarak tanam cukup rapat. Hal ini memberikan pembatas visual dari jalan ke arah bangunan.

Segmen 2, penilaian pada segmen ini menunjukkan 62,5\% dari 4 kriteria terpenuhi dan dikategorikan baik. Pada median jalan masih ditanami dengan pohon bintaro, palem putri dan palem merah yang dikombinasikan dengan perdu dan penutup tanah. Penanaman yang rapat membentuk massa, massa daun rapat sehingga cukup baik sebagai pembatas visual antara kedua ruas jalan. Pada kedua sisi memiliki penanaman yang berbeda. Pada satu sisi ditanami pohon mahoni dengan jarak tidak rapat sehingga kurang memberi kesan pembatas visual. Pada sisi jalan yang lain yaitu di depan rumah gubernur terdapat planting box yang diletakkan sepanjang jalan. Planting box ditanami bougenvil. Tinggi tanaman yang kurang lebih 1,5 meter, jarak antar planting box cukup rapat. Peletakan planting box ditanami bougenvil cukup membantu dalam membetasi pandangan.

Segmen 3, penilaian pada segmen ini menunjukkan 75\% dari 4 kriteria terpenuhi dan termasuk kedalam kategori baik. Pada segmen ini satu sisi jalan ditanami pohon glodogan bulat yang ditanam dengan jarak rapat, berbaris membentuk massa. Tajuk pohon glodogan bulat saling bersinggungan. Pada sisi jalan yang lain ditanami pohon mahoni dengan jarak tanam kurang rapat. Pada median jalan ditanami pohon bintaro, palem putri dan palem merah dikombinasikan dengan 
perdu. Pada median jalan ini jarak tanam rapat, ditanam berbaris membentuk massa, massa daun rapat, dan terdapat kombinasi pohon dan perdu. Hal ini memberikan pembatas visual. Pada Gambar 20 dapat dilihat median jalan yang ditanami kombinasi pohon, perdu, penutup tanah dengan jarak rapat dan tepian jalan yang ditanami pohon glodogan tiang sebagai pembatas visual pada jalan.

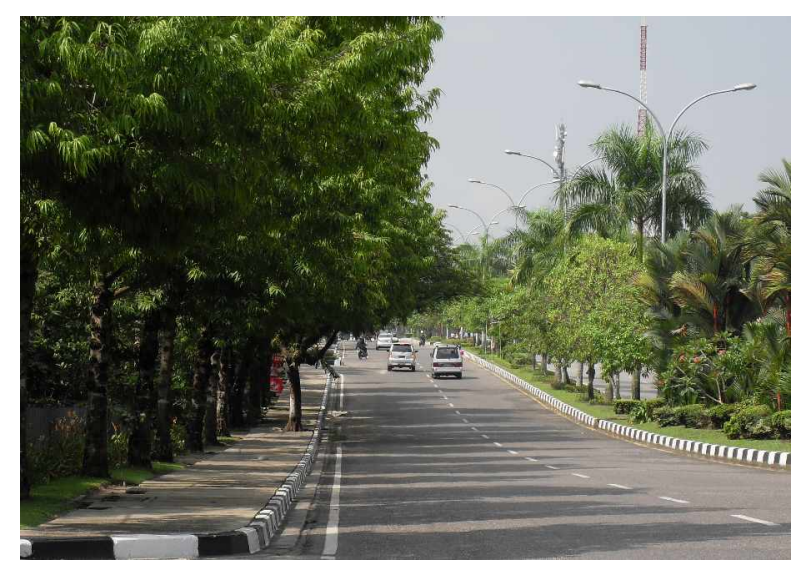

Gambar 20. Deretan Pohon Ditanam Rapat Menjadi Pembatas Visual ke Arah Hutan Kota di Jalan Diponegoro

Segmen 4, penilaian pada segmen ini menunjukkan 75\% dari 4 kriteria terpenuhi dan termasuk kedalam kategori baik. Pada median jalan ditanami pohon bintaro, palem putri dan palem merah dikombinasikan dengan perdu dan penutup tanah. Penanaman yang rapat dan membentuk massa memberikan pembatas visual antara dua jalan. Penanaman pada sisi jalan berupa pohon tanjung, mahoni dan glodogan tiang. Penanaman cukup rapat, massa daun padat, ditanam berbaris sepanjang jalan.

Menurut Carpenter et al. (1975), tanaman dapat pula difungsikan sebagai panghalang fisik yang bertujuan untuk menahan gerak manusia, hewan dan kenderaan dari luar jalan serta penyangga kecelakaan untuk meminimalisasi kerusakan yang dapat terjadi. Salah satu fungsi tanaman pada tapak adalah membatasi pandangan dari visual yang kurang menyenangkan (bad view), visual yang kurang menyenangkan tersebut dapat diatasi dengan penyusunan vegetasi yang berkelompok dan membentuk barrier (De Chiara dan Koppelman, 1982). Menurut Vitasari (2004), pada lokasi studinya penggunaan tanaman yang dikombinasikan dengan pagar pembatas dapat dijadikan sebagai alternatif 
terutama pada area yang berbatasan dengan area lain dengan aktivitas cukup tinggi. Pohon yang dapat digunkan sebagai pembatas pandangan yaitu cemara, bambu pagar, kembang sepatu, oleander (Departemen PU Direktorat Bina Marga, 1996).

\section{Fungsi Peneduh}

Kriteria tanaman berfungsi sebagai peneduh yaitu, pohon dengan tinggi sedang atau tinggi $<15 \mathrm{~m}$, bentuk tajuk spreading, bulat, dome, irregular, tajuk bersinggungan, massa daun padat, percabangan $5 \mathrm{~m}$ di atas tanah, ditanam secara berkesinambungan atau teratur. Penilaian tanaman sebagai fungsi peneduh dapat dilihat pada Tabel 13 .

Tabel 13. Penilaian Fungsi Peneduh

\begin{tabular}{|c|c|c|c|c|c|c|c|c|c|}
\hline \multirow[t]{2}{*}{ Nama Jalan } & \multirow[t]{2}{*}{ Segmen } & \multicolumn{6}{|c|}{ Kriteria Penilaian } & \multirow{2}{*}{$\begin{array}{c}\text { Skor } \\
(\%)\end{array}$} & \multirow[t]{2}{*}{ Kategori } \\
\hline & & 1 & 2 & 3 & 4 & 5 & 6 & & \\
\hline \multirow{4}{*}{$\begin{array}{ll}\text { Cut } & \text { Nyak } \\
\text { Dien } & \end{array}$} & 1 & 3 & 2 & 2 & 3 & 2 & 3 & 62,5 & Baik \\
\hline & 2 & 3 & 1 & 1 & 1 & 1 & 3 & 41,7 & Sedang \\
\hline & 3 & 3 & 2 & 2 & 2 & 2 & 3 & 58,3 & Sedang \\
\hline & 4 & 3 & 3 & 3 & 3 & 2 & 3 & 70,8 & Baik \\
\hline \multicolumn{8}{|l|}{ Total Rata-rata } & 58,3 & Sedang \\
\hline \multirow[t]{8}{*}{ Sudirman } & 1 & 4 & 3 & 3 & 4 & 3 & 3 & 83,3 & SangatBaik \\
\hline & 2 & 4 & 4 & 4 & 4 & 4 & 3 & 95,8 & Sangat Baik \\
\hline & 3 & 4 & 4 & 4 & 3 & 4 & 4 & 95,8 & Sangat Baik \\
\hline & 4 & 3 & 3 & 2 & 3 & 2 & 2 & 62,5 & Baik \\
\hline & 5 & 3 & 3 & 2 & 3 & 2 & 2 & 62,5 & Baik \\
\hline & 6 & 4 & 4 & 4 & 3 & 4 & 3 & 91,7 & Sangat Baik \\
\hline & 7 & 3 & 3 & 3 & 3 & 3 & 3 & 75 & Baik \\
\hline & 8 & 3 & 2 & 3 & 2 & 2 & 3 & 62,5 & Baik \\
\hline \multicolumn{8}{|l|}{ Total Rata-rata } & 78,6 & Baik \\
\hline Gajah Mada & 1 & 3 & 2 & 1 & 2 & 3 & 3 & 58,3 & Sedang \\
\hline \multicolumn{8}{|l|}{ Total Rata-rata } & 58,3 & Baik \\
\hline \multirow[t]{4}{*}{ Diponegoro } & 1 & 3 & 4 & 4 & 3 & 3 & 3 & 83,3 & Sangat Baik \\
\hline & 2 & 2 & 2 & 1 & 3 & 1 & 3 & 50 & Sedang \\
\hline & 3 & 3 & 3 & 3 & 3 & 4 & 3 & 79,2 & Baik \\
\hline & 4 & 3 & 3 & 3 & 3 & 3 & 3 & 75 & Baik \\
\hline \multicolumn{8}{|l|}{ Total Rata-rata } & 71,8 & Baik \\
\hline \multicolumn{10}{|l|}{ Keterangan : } \\
\hline
\end{tabular}

\section{Jalan Cut Nyak Dien}

Segmen 1, penilaian pada segmen ini menunjukkan bahwa 62,5\% dari 6 kriteria terpenuhi dan termasuk kedalam kategori baik. Penanaman pohon mahoni di kedua sisi jalan dengan jarak cukup rapat, berkesinambungan. Tetapi pohon 
mahoni masih berumur muda sehingga tajuk tidak bersinggungan. Percabangan diatas $5 \mathrm{~m}$, berarsitektur tajuk irregular. Hal ini cukup memberikan peneduh walaupun tidak efektif sebab pohon masih muda. Pada median jalan ditanami palem dikombinasikan dengan perdu. Jarak tanam rapat dan massa daun padat.

Segmen 2, penilaian pada segmen ini menunjukkan bahwa 41,7\% dari 6 kriteria terpenuhi dan termasuk kedalam kategori sedang. Kedua sisi jalan ditanami pohon palem diselingi oleh mahoni. Pohon mahoni masih berumur muda dan tingginya sekitar $5 \mathrm{~m}$. Jarak tanam rapat, massa daun kurang padat, dan tajuk palem tidak dapat memberikan teduhan.

Segmen 3, penilaian pada segmen ini menunjukkan bahwa 58,3\% dari 6 kriteria terpenuhi dan termasuk kedalam kategori sedang. Pohon mahoni yang ditanam di tepi jalan dengan jarak cukup rapat, tajuk spreading, massa daun padat memberikan peneduh pada jalan. Pada satu sisi jalan terdapat cemara lilin yang ditanam rapat sepanjang jalan, hal ini dapat memberikan fungsi peneduh pada jalan. Pada median jalan ditanami palem dan kombinasi kembang merak, cassia glauca dan perdu. Tanaman ditanam kurang rapat sehingga fungsi peneduh kurang.

Segmen 4, penilaian pada segmen ini menunjukkan bahwa 70,8\% dari 6 kriteria terpenuhi dan termasuk kedalam kategori baik. Pada segmen ini di ruas jalan samping BI ditanami pohon tanjung yang ditanam rapat, ditepi jalan ,berbaris, tajuk saling bersinggungan dan massa daun padat. Peletakkan pohon ini memberi naungan pada ruas jalan. Pada segmen lain di tepi jalannya ditanami pohon beraneka ragam seperti mahoni, tanjung, matoa. Tajuk pohon yang irregular, round, saling bersinggungan dengan massa daun padat cukup memberikan naungan. Pohon-pohon ditanam teratur di sepanjang jalan.

\section{Jalan Sudirman}

Segmen 1, penilaian pada segmen ini menunjukkan bahwa 83,3\% dari 6 kriteria terpenuhi dan termasuk kedalam kategori sangat baik. Median jalan yang ditanami pohon angsana yang tinggi dengan tajuk yang saling bersinggungan, massa daun padat, percabangannya $5 \mathrm{~m}$ diatas tanah, dan ditanam secara teratur sepanjang median jalan. Percabangan yang lebar memberikan naungan pada ruas jalan dan 
meneduhkan. Pada segmen ini tidak terdapat tepi jalan yang ditanami pohon, sehingga peneduh hanya didapat dari median jalan yang menaungi setengah ruas jalan.

Segmen 2, penilaian pada segmen ini menunjukkan bahwa 95,8\% dari 6 kriteria terpenuhi dan termasuk kedalam kategori sangat baik. Masih sama dengan segmen sebelumnya, pada segmen ini pohon angsana ditanam rapat dengan tajuk saling bersinggungan dan memberikan daerah naungan di bawahnya.

Segmen 3, penilaian pada segmen ini menunjukkan bahwa 95,8\% dari 6 kriteria terpenuhi dan termasuk kedalam kategori sangat baik. Pada segmen pohon angsana yang tinggi ditanam teratur dipadukan dengan perdu dan tanaman yang merambat sepanjang pagar pembatas. Pohon angsana memberikan naungan di bawahnya melalui tajuk yang saling bersinggungan, massa daun yang padat, dan ditanam teratur. Selain itu di kedua sisi jalan ditanami pohon mahoni yang ditanam teratur, dengan massa daun padat dan ini memberikan peneduh pada ruas jalan. Sehingga jalan mendapat daerah naungan dari median dan tepi jalan.

Segmen 4, penilaian pada segmen ini menunjukkan bahwa 62,5\% dari 6 kriteria terpenuhi dan termasuk kedalam kategori baik. Pada segmen ini penaung dari median tidak didapat dengan sempurna. Pada median jalan ditanami cemara udang dan perdu yang dibentuk berpola membentuk taman. Pohon yang ditanami pada median memiliki jarak yang tidak rapat dan masih muda sehingga tidak dapat sempurna memberikan naungan pada jalan. Pada tepi jalan ditanami pohon mahoni dengan jarak cukup rapat, massa daun padat, ditanam teratur sepanjang jalan. Naungan yang bagus didapat pada segmen tepi jalan yang ditanami jejeran pohon bintaro dengan tajuk bersinggungan, dan massa daun padat.

Segmen 5, penilaian pada segmen ini menunjukkan bahwa 62,5\% dari 6 kriteria terpenuhi dan termasuk kedalam kategori baik. Kedua sisi jalan ditanami pohon mahoni dengan jarak rapat tetapi umur pohon yang masih muda menyebabkan tajuk belum maksimal dan daerah naungan tidak cukup luas. Median jalan yang ditanami pohon bintaro secara teratur dengan bentuk tajuk bulat dan massa daun yang padat memberikan daerah naungan pada ruas jalan.

Segmen 6, penilaian pada segmen ini menunjukkan bahwa 91,6\% dari 6 kriteria terpenuhi dan termasuk kedalam kategori sangat baik. Pada segmen ini adalah 
segmen dengan daerah naungan terbaik di sepanjang segmen jalan. Median jalan yang ditanami dengan pohon angsana yang tinggi, tajuk yang saling bersinggungan, dengan massa daun rapat, percabangan di atas $5 \mathrm{~m}$ dan ditanam secara teratur membentuk daerah naungan pada ruas jalan. Pada kedua sisi jalan juga ditanami pohon mahoni yang tajuknya saling bersinggungan dan memiliki massa daun yang padat dengan percabangan diatas $5 \mathrm{~m}$. Tajuk pohon pada median dan tepi jalan saling bersinggungan sehingga membentuk daerah naungan pada ruas jalan dengan sempurna. Pada Gambar 21 dapat dilihat pohon sebagai fungsi peneduh pada Jalan Sudirman segmen 6.

Segmen 7, penilaian pada segmen ini menunjukkan bahwa 75\% dari 6 kriteria terpenuhi dan termasuk kedalam kategori baik. Pada segmen ini daerah tepi jalan yang ditanami pohon mahoni memiliki tajuk yang saling bersinggungan dengan massa daun rapat dan tajuk berbentuk spreading. Penanaman pohon mahoni secara teratur di sepanjang jalan memberikan naunggan di setengah ruas jalan. Pada median jalan ditanami barisan palem dikombinasikan dengan perdu. Tinggi pohon palem yang ditanam secara teratur dapat memberikan naungan pada jalan.

Segmen 8, penilaian pada segmen ini menunjukkan bahwa 62,5\% dari 6 kriteria terpenuhi dan termasuk kedalam kategori baik. Pada segmen ini kedua sisi jalan ditanami pohon kelapa sawit. Median jalan ditanami palem merah, bougenvil, nusa indah dikombinasikan denga perdu. Secara umum daerah ini dapat memberikan fungsi peneduh sebab tajuk yang saling bersinggungan pada median jalan, pohon-pohon besar lain yang berada di dekat tepi jalan dan jarak tanam yang cukup rapat.

\section{Jalan Gajah mada}

Segmen 1, penilaian pada segmen ini menunjukkan bahwa 58,3\% dari 6 kriteria terpenuhi dan termasuk kedalam kategori sedang. Pada tepi kedua sisi jalan ditanami secara teratur dengan jarak rapat pohon mahoni. Pohon mahoni masih berumur muda sehingga massa daun dan percabangan belum sempurna dan tajuk tidak saling bersinggunggan. Tajuk pohon mahoni spreading dan tingginya kurang lebih $6 \mathrm{~m}$. Pohon sepanjang jalan belum dapat memberikan naungan pada ruas jalan diakibatkan penanaman pohon yang masih baru. 


\section{Jalan Diponegoro}

Segmen 1, penilaian pada segmen ini menunjukkan bahwa 83,3\% dari 6 kriteria terpenuhi dan termasuk kedalam kaetgori sangat baik. Pohon tanjung yang mempunyai tinggi sedang, tajuk bulat, tajuk saling bersinggungan, massa daun padat, ditanam secara teratur di sepanjang kedua tepi jalan. Penanaman pohon ini memberikan naungan pada ruas jalan. Median jalan yang ditanami pohon bintaro dan palem juga memberikan naungan pada jalan. Tajuk yang saling bersinggungan dan ditanam secara teratur pada median jalan.

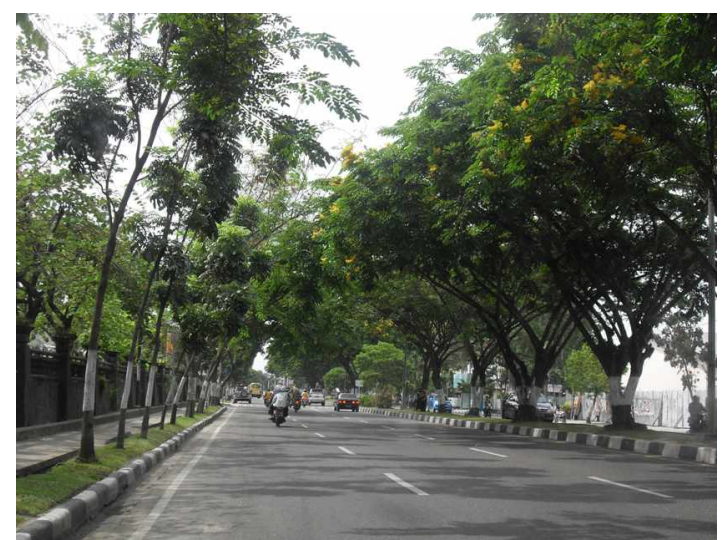

Gambar 21. Deretan Pohon Angsana dan Mahoni Sebagai Fungsi Peneduh di Jalan Sudirman

Segmen 2, penilaian pada segmen ini menunjukkan bahwa 50\% dari 6 kriteria terpenuhi dan termasuk kedalam kategori sedang. Segmen jalan ini terdapat pohon mahoni pada satu sisi jalan yang ditanam dengan jarak renggang sehingga kurang memberikan naungan. Tajuk pohon tidak saling bersinggungan dan sebab tanaman ini masih berumur muda. Pada satu sisi jalan yang lain hanya diletakkan planting box yang ditanami bougenvil. Planting box ini ditanam jauh dari tepi jalan sehingga kurang memberikan naungan pada ruas jalan. Pada median jalan naungan didapatkan dari penanaman palem dan pohon bintaro yang ditanam teratur sepanjang median jalan dengan bentuk tajuk bulat dan palmae.

Segmen 3, penilaian pada segmen ini menunjukkan bahwa 79,2\% dari 6 kriteria terpenuhi dan termasuk kedalam kategori baik. Fungsi peneduh dapat terlihat pada satu tepi jalan yang ditanami glodogan bulat. Pohon glodogan bulat ditanam teratur dengan tajuk saling bersinggungan, massa daun padat dan percabangan 5 $\mathrm{m}$ diatas tanah. Pohon ini memberikan naungan hampir setengah ruas jalan. Pada 
satu sisi jalan yang lain ditanami pohon mahoni secara teratur dengan bentuk tajuk spreading, tetapi tajuk pohon tidak saling bersinggungan. Fungsi penaung masih dapat tercipta dari tinggi pohon mahoni.

Segmen 4, penilaian pada segmen ini menunjukkan bahwa $75 \%$ dari 6 kriteria terpenuhi dan termasuk kedalam kategori baik. Pada sisi jalan ditanami berbagai macam jenis pohon seperti tanjung, mahoni, glodogan, dan akasia. Campuran bentukan tajuk yang saling bersinggungan memberikan naungan. Pohon-pohon ini berukuran tinggi, massa daun padat, dan ditanam secara teratur di sepanjang jalan. Pada median jalan naungan tercipta dari pohon bintaro yang ditanam dengan jarak rapat, bertajuk bulat, dan massa daun padat.

Pohon yang diajurkan Dinas PU Bina Marga (1996) sebagai peneduh yaitu angsana, tanjung, krei payung. Penggunaan tanaman sebagai peneduh dapat dilakukan dengan penanaman pohon yang tajuknya bersinggungan dan lebar, seperti pohon yang memiliki tajuk horizontal, bulat, dome, atau irregular yang memiliki daun rimbun dan ditanam secara kontiniu (Vitasari, 2004). Vegetasi dapat mengontrol iklim mikro di sekitarnya dengan memperbaiki suhu udara di lingkungannya (Simonds, 1983).

\section{Fungsi Kontrol Cahaya}

Kriteria tanaman berfungsi sebagai kontrol cahaya yaitu ditanam rapat atau berkelompok, tanaman perdu ketinggian 61,5 m atau pohon dengan ketinggian $16 \mathrm{~m}$, bermassa daun padat atau rimbun. Penilaian dapat dilihat pada Tabel 14.

Tabel 14. Penilaian Fungsi Kontrol Cahaya

\begin{tabular}{|c|c|c|c|c|c|c|}
\hline \multirow[t]{2}{*}{ Nama Jalan } & \multirow[t]{2}{*}{ Segmen } & \multicolumn{3}{|c|}{ Kriteria Penilaian } & \multirow[t]{2}{*}{ Skor (\%) } & \multirow[t]{2}{*}{ Kategori } \\
\hline & & 1 & 2 & 3 & & \\
\hline \multirow{4}{*}{$\begin{array}{ll}\text { Cut } & \text { Nyak } \\
\text { Dien } & \end{array}$} & 1 & 2 & 2 & 3 & 58,3 & Baik \\
\hline & 2 & 3 & 2 & 2 & 58,3 & Sedang \\
\hline & 3 & 3 & 2 & 2 & 58,3 & Baik \\
\hline & 4 & 3 & 2 & 3 & 66,7 & Baik \\
\hline \multicolumn{5}{|l|}{ Total Rata-rata } & 60,4 & Sedang \\
\hline \multirow[t]{8}{*}{ Sudirman } & 1 & 3 & 3 & 3 & 75 & Baik \\
\hline & 2 & 3 & 1 & 3 & 58,3 & Baik \\
\hline & 3 & 3 & 3 & 3 & 75 & Baik \\
\hline & 4 & 3 & 3 & 3 & 75 & Baik \\
\hline & 5 & 3 & 3 & 3 & 75 & Baik \\
\hline & 6 & 4 & 1 & 4 & 75 & Baik \\
\hline & 7 & 4 & 3 & 3 & 83,3 & Sangat Baik \\
\hline & 8 & 3 & 3 & 2 & 66,7 & Baik \\
\hline \multicolumn{5}{|l|}{ Total Rata-rata } & 72,9 & Baik \\
\hline
\end{tabular}


Tabel 14. (Lanjutan)

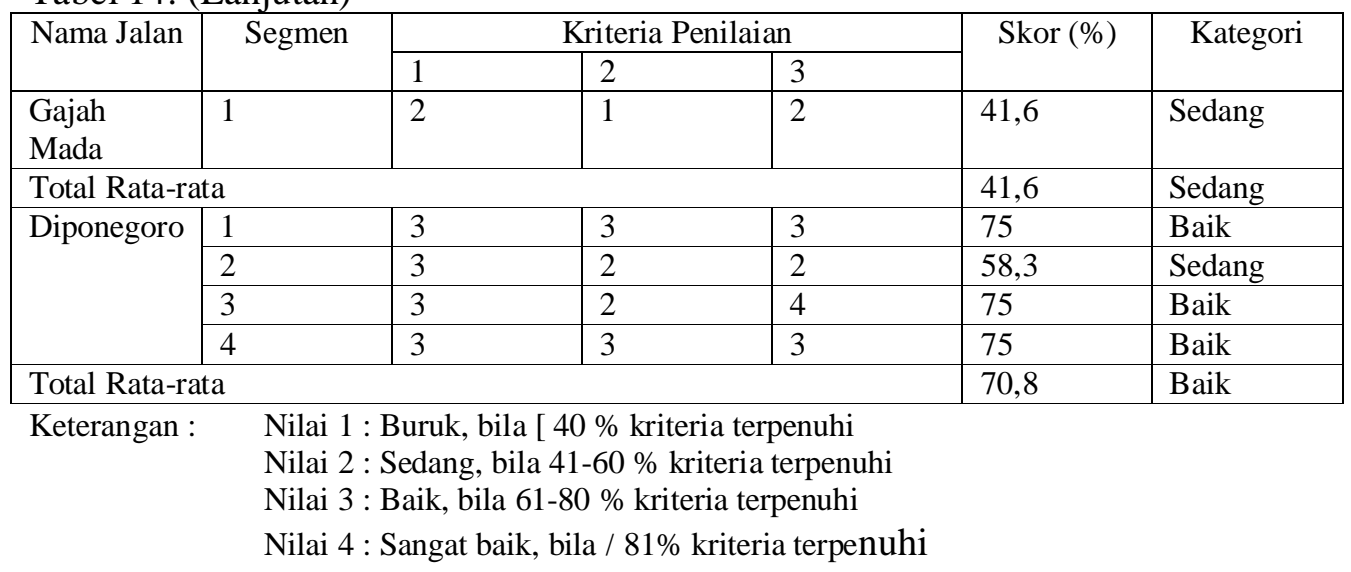

\section{Jalan Cut Nyak Dien}

Segmen 1, penilaian pada segmen ini menunjukkan bahwa 58,3\% dari 3 kriteria terpenuhi dan termasuk kedalam kategori baik. Segmen jalan ini memiliki median jalan yang ditanami palem putri dengan jarak rapat. Selain itu median jalan juga ditanami dengan perdu dan penutup tanah yang bermassa daun padat dan memiliki daun sempit. Pada kedua sisi tepi jalan ditanami pohon mahoni dengan jarak rapat, rimbun. Peletakkan tanaman ini pada jalan dapat mengontrol cahaya.

Segmen 2, penilaian pada segmen ini menunjukkan bahwa 58,3\% dari 3 kriteria terpenuhi dan termasuk kedalam kategori sedang. Kontrol silau matahari kurang tercipta. Pada kedua sisi jalan yang ditanami palem dan diselinggi dengan mahoni, tanaman tersebut ditanam rapat. Tetapi tidak memiliki daun rimbun dan pohon mahoni masih berumur muda.

Segmen 3, penilaian pada segmen ini menunjukkan bahwa 58,3\% dari 3 kriteria terpenuhi dan termasuk kedalam kategori baik. Pada kedua sisi jalan ditanami pohon mahoni. Tajuk pohon saling bersinggungan. Terdapat juga pohon cemara lilin yang ditanam rapat pada satu sisi. Daunnya yang rimbun dapat memberikan kontrol silau sinar matahari dan cahaya lampu pada jalan. Median jalan ditanami kembang merak dan dipadukan dengan perdu.

Segmen 4, penilaian pada segmen ini menunjukkan bahwa 66,7\% dari 3 kriteria terpenuhi dan termasuk kedalam kategori baik. Pada segmen jalan ini sepanjang kedua sisi jalan ditanami berbagai macam pohon seperti mahoni, tanjung, dan matoa. Pohon ini ditanam dengan jarak rapat, memiliki massa daun padat, berdaun 
sempit. Tajuk pohon saling bersinggungan menahan cahaya matahari dan menjadi kontrol silau dari lampu jalan atau kenderaan.

\section{Jalan Sudirman}

Segmen 1, penilaian pada segmen ini menunjukkan bahwa $75 \%$ dari 3 kriteria terpenuhi dan termasuk kedalam kategori baik. Pohon angsana yang ditanam rapat di sepanjang jalan mempunyai tajuk yang saling bersinggungan dan berguna untuk mengontrol silau matahari. Daunnya rimbun dan pada median jalan ini juga memiliki planting box yang ditanami perdu. Peletakan planting box ini juga dapat membantu mengatasi silau cahaya lampu kenderaan.

Segmen 2, penilaian pada segmen ini menunjukkan bahwa 58,3\% dari 3 kriteria terpenuhi dan termasuk kedalam kategori baik. Median jalan ditanami pohon angsana secara rapat. Tajuknya saling bersinggungan dan rimbun. Kombinasi ini cukup memberikan fungsi sebagai kontrol silau cahaya matahari dan lampu kenderaan.

Segmen 3, penilaian pada segmen ini menunjukkan bahwa $75 \%$ dari 3 kriteria terpenuhi dan termasuk kedalam kategori baik. Pada segmen ini pada median jalan ditanami pohon angsana. Pohon angsana ditanam rapat, rimbun, dan tajuknya saling bersinggunggan. Tajuk pohon dapat melindungi pengguna jalan dari silau matahari dan lampu jalan. Pada median jalan juga ditanami perdu dan penutup tanah yang juga membantu dalam mengatasi silau cahaya dan lampu kenderaan.

Segmen 4, penilaian pada segmen ini menunjukkan bahwa $75 \%$ dari 3 kriteria terpenuhi dan termasuk kedalam kategori baik. Pada segmen ini terdapat pohon angsana yang dikombinasikan dengan perdu dan penutup tanah. Median jalan yang ditanami kombinasi ketiga tanaman membentuk taman dapat menjadi penghalang silau cahaya matahari. Jarak tanam angsana kurang rapat, tetapi penanaman perdu pada median jalan yang rapat membantu dalam mengontrol silau cahaya matahari. Penanaman pohon mahoni sepanjang jalan pun dapat menjadi kontrol silau cahaya matahari melalui tajuknya.

Segmen 5, penilaian pada segmen ini menunjukkan bahwa $75 \%$ dari 3 kriteria terpenuhi dan termasuk kedalam kategori baik. Ruas jalan ini memiliki median 
jalan ditanami pohon bintaro yang rimbun, jarak tanam rapat, daun tebal, dan median jalan memiliki perdu/semak. Kombinasi penanaman ini dapat menjadi antisipasi silau cahaya matahari. Kedua sisi jalan pun memiliki pohon mahoni yang ditanam rapat dan dapat menjadi penghalang silau matahari pada jalan.

Segmen 6, penilaian pada segmen ini menunjukkan bahwa $75 \%$ dari 3 kriteria terpenuhi dan termasuk kedalam kategori baik. Pada ruas jalan ini tajuk pohon pada median dan tepi jalan saling bersinggungan. Lebar tajuk pohon angsana yang besar pada median jalan menjadi penghalang dari silau cahaya matahari. Pada kedua tepi jalan ditanami pohon mahoni yang memiliki tajuk lebar yang membantu menghalangi silau cahaya.

Segmen 7, penilaian pada segmen ini menunjukkan bahwa 83,3\% dari 3 kriteria terpenuhi dan termasuk kedalam kategori sangat baik. Sepanjang jalan tajuk pohon mahoni saling bersinggungan. Tajuk pohon ini memberikan naungan pada setengah ruas jalan. Tajuk pohon mahoni menjadi penghalang silau cahaya matahari. Median jalan pun ditanami pohon palem yang dikombinasikan dengan perdu dan penutup tanah. Perdu-perdu yang memiliki tinggi kurang lebih 1,5 m dapat menjadi penahan silau cahaya matahari dan lampu kenderaan. Pada Gambar 22 dapat dilihat pohon sebagai fungsi peneduh pada Jalan Sudirman segmen 7.

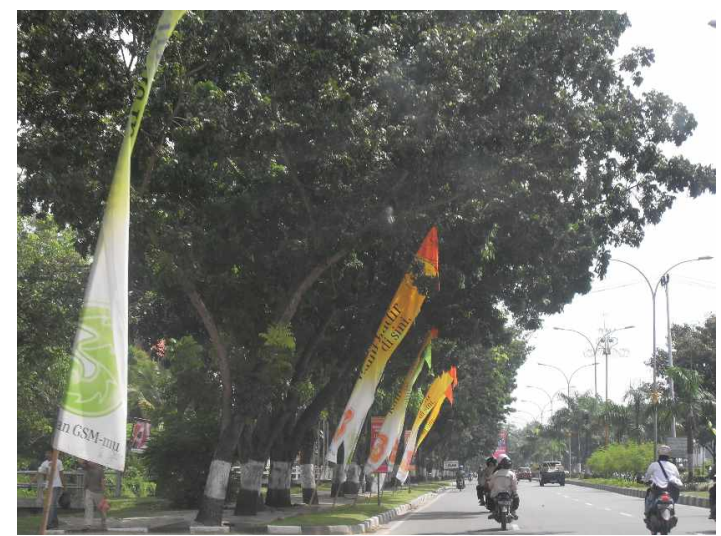

Gambar 22. Deretan Pohon Mahoni di Sepanjang Jalan Sudirman Sebagai Fungsi Kontrol Cahaya

Segmen 8, penilaian pada segmen ini menunjukkan bahwa 66,7\% dari 3 kriteria terpenuhi dan termasuk kedalam kategori baik. Kelapa sawit yang ditanam berbaris sepanjang jalan dengan jarak cukup rapat. Tajuk kelapa sawit saling bersinggungan dan dapat mengantisipasi silau cahaya. Median jalan yang 
ditanami pohon (palem, bougenvil, nusa indah) dan perdu yang rimbun, berkesinambungan juga menjadi penghalang dari silau matahari dan silau lampu kenderaan.

\section{Jalan Gajah Mada}

Segmen 1, penilaian pada segmen ini menunjukkan bahwa 41,6\% dari 3 kriteria terpenuhi dan termasuk kedalam kategori sedang. Ruas jalan ini memiliki lebar 22 m tanpa median jalan. Pohon mahoni ditanam disepanjang kedua tepi jalan. Pohon mahoni ini ditanam dengan jarak yang tidak rapat. Pohon mahoni ini merupakan pohon yang baru ditanam sehingga daun belum rindang dan tajuk antar pohon belum maksimum.

\section{Jalan Diponegoro}

Segmen 1, penilaian pada segmen ini menunjukkan bahwa $75 \%$ dari 3 kriteria terpenuhi dan termasuk kedalam kategori baik. Pohon tanjung ditanam rapat di kedua sisi jalan. Tajuknya yang saling bersinggungan menjadi penahan silau matahari. Median jalan ditanami pohon bintaro dan palem dikombinasikan dengan perdu dan penutup tanah ditanam rapat mengurangi silau matahari dan lampu kenderaan pada jalan.

Segmen 2, penilaian pada segmen ini menunjukkan bahwa 58,3\% dari 3 kriteria terpenuhi dan termasuk kedalam kategori sedang. Pada segmen ini median jalan yang ditanami pohon bintaro dan palem yang dikombinasikan dengan perdu dan penutup tanah ditanam rapat cukup dapat menahan silau cahaya matahari dan lampu kenderaan. Tepi jalan yang ditanami pohon mahoni belum dapat mengatasi silau matahari karena pohon yang berumur muda dan penanaman yang kurang rapat. Pada sisi jalan yang lain ditempatkan planting box yang ditanami bougenvil.

Segmen 3, penilaian pada segmen ini menunjukkan bahwa $75 \%$ dari 3 kriteria terpenuhi dan termasuk kedalam kategori baik. Satu sisi jalan ditanami glodogan bulat yang memiliki daun rimbun. Glodogan bulat ditanam cukup rapat dan tajuknya saling bersinggungan. Hal ini dapat mengantisipasi silau cahaya matahari. Pada satu sisi jalan yang lain ditanami mahoni dengan jarak rapat. Median jalan cukup membantu dalam mengatasi silau matahari dan lampu 
kenderaan. Hal ini dikarenakan kombinasi pohon (palem, bintaro), perdu dan penutup tanah yang ditanam rapat.

Segmen 4, penilaian pada segmen ini menunjukkan bahwa $75 \%$ dari 3 kriteria terpenuhi dan termasuk kedalam kategori baik. Tepi jalan ditanami berbagai macam pohon seperti tanjung, mahoni dan glodogan. Pohon-pohon ditanam cukup rapat dengan tajuk saling bersinggungan. Tajuk yang saling bersinggungan berguna untuk mengontrol sinar matahari dan lampu kenderaan pada jalan. Median jalan yang ditanami pohon bintaro dan palem yang dikombinasikan dengan perdu ditanam rapat juga membantu menghalangi sinar matahari dan lampu kenderaan.

Menurut Laurie (1986), tanaman akan efektif mengontrol kesilauan bila dilakukan penanaman pohon berdaun tebal, rindang, dan evergreen sehingga dapat memberikan toleransi sebagai fungsi kontrol cahaya. Tanaman pada median jalan yang dapat digunakan seperti bougenvil, nusa indah, oleander, kembang sepatu (Dinas PU Direktorat Bina Marga, 1996). Menurut Vitasari (2004), keefektifan tanaman sebgai pengontrol kesilauan sangat tergantung dari ukuran (karakteristik) dari tajuk tanaman, misalnya beberapa jenis tanaman dengan tajuk yang sangat lebar dapat efektif sebagai barrier dengan hanya ditanam dalam satu baris dan untuk jenis lain yang tajuknya lebih sempit harus ditanam dalam beberapa baris.

\section{Fungsi Kontrol Bunyi}

Kriteria tanaman sebagai fungsi kontrol bunyi yaitu, beberapa lapis tanaman, ditanam dekat jalan, kombinasi pohon,perdu, dan semak, bermassa daun padat, terdapat variasi tajuk secara vertikal. Penilaian dapat dilihat pada Tabel 15. Tabel 15. Penilaian Fungsi Kontrol Bunyi

\begin{tabular}{|c|c|c|c|c|c|c|c|c|}
\hline \multirow[t]{2}{*}{ Nama Jalan } & \multirow[t]{2}{*}{ Segmen } & \multicolumn{5}{|c|}{ Kriteria Penilaian } & \multirow[t]{2}{*}{ Skor $(\%)$} & \multirow[t]{2}{*}{ Kategori } \\
\hline & & 1 & 2 & 3 & 4 & 5 & & \\
\hline \multirow[t]{4}{*}{ Cut Nyak Dien } & 1 & 2 & 3 & 2 & 3 & 3 & 65 & Baik \\
\hline & 2 & 1 & 3 & 2 & 2 & 3 & 55 & Baik \\
\hline & 3 & 3 & 3 & 3 & 2 & 2 & 65 & Baik \\
\hline & 4 & 4 & 4 & 4 & 3 & 2 & 65 & Baik \\
\hline \multicolumn{7}{|l|}{ Total Rata-rata } & 62,5 & Baik \\
\hline \multirow[t]{4}{*}{ Sudirman } & 1 & 3 & 3 & 3 & 3 & 3 & 75 & Baik \\
\hline & 2 & 1 & 3 & 1 & 3 & 3 & 50 & Sedang \\
\hline & 3 & 1 & 3 & 1 & 3 & 3 & 56,25 & Sedang \\
\hline & 4 & 3 & 3 & 3 & 3 & 2 & 75 & Baik \\
\hline
\end{tabular}


Tabel 15. (Lanjutan)

\begin{tabular}{|c|c|c|c|c|c|c|c|c|}
\hline \multirow[t]{2}{*}{ Nama Jalan } & \multirow[t]{2}{*}{ Segmen } & \multicolumn{5}{|c|}{ Kriteria Penilaian } & \multirow{2}{*}{$\begin{array}{c}\text { Skor } \\
(\%)\end{array}$} & \multirow[t]{2}{*}{ Kategori } \\
\hline & & 1 & 2 & 3 & 4 & 5 & & \\
\hline & 5 & 3 & 3 & 3 & 3 & 2 & 75 & Baik \\
\hline & 6 & 2 & 3 & 2 & 3 & 3 & 62,5 & Baik \\
\hline & 7 & 3 & 3 & 3 & 3 & 3 & 75 & Baik \\
\hline & 8 & 2 & 3 & 3 & 2 & 2 & 62,5 & Baik \\
\hline \multicolumn{7}{|c|}{ Total Rata-rata } & 66,4 & Baik \\
\hline $\begin{array}{l}\text { Gajah } \\
\text { Mada }\end{array}$ & 1 & 1 & 3 & 1 & 2 & 2 & 45 & Sedang \\
\hline \multicolumn{7}{|c|}{ Total Rata-rata } & 45 & Sedang \\
\hline \multirow[t]{4}{*}{ Diponegoro } & 1 & 3 & 3 & 3 & 3 & 3 & 80 & $\begin{array}{l}\text { Sangat } \\
\text { Baik }\end{array}$ \\
\hline & 2 & 3 & 3 & 2 & 2 & 2 & 60 & Baik \\
\hline & 3 & 3 & 3 & 2 & 3 & 3 & 70 & Baik \\
\hline & 4 & 3 & 3 & 2 & 3 & 2 & 65 & Baik \\
\hline \multicolumn{7}{|c|}{ Total Rata-rata } & 68,75 & Baik \\
\hline \multicolumn{9}{|l|}{ Keterangan : } \\
\hline
\end{tabular}

\section{Jalan Cut Nyak Dien}

Segmen 1, penilaian pada segmen ini menunjukkan bahwa $65 \%$ dari 5 kriteria terpenuhi dan termasuk kedalam kategori baik. Median jalan ditanami dengan beberapa lapis tanaman dengan massa daun padat. Kombinasi pohon palem, perdu dan penutup tanah ditanam di sepanjang median jalan. Sepanjang kedua sisi jalan ditanami pohon mahoni. Pohon mahoni ini ditanam dekat dengan jalan. Hal ini dapat menjadi kontrol bunyi pada jalan.

Segmen 2, penilaian pada segmen ini menunjukkan bahwa 55\% dari 5 kriteria terpenuhi dan termasuk kedalam kategori sedang. Pada ruas jalan ini hanya ditanami pohon saja. Pohon yang ditanam yaitu berupa palem raja dan mahoni. Tetapi pada satu sisi jalan ditanami soka dengan massa daun padat.

Segmen 3, penilaian pada segmen ini menunjukkan bahwa $65 \%$ dari 5 kriteria terpenuhi dan termasuk kedalam kategori baik. Ruas jalan ini ditanami pohon mahoni yang ditanam dekat dengan jalan dengan jarak tanam cukup rapat, bermassa daun padat. Pohon palem, kembang merak dan cassia glauca dikombinasikan dengan bakung terdapat pada median jalannya. Pada Gambar 23 dapat dilihat pohon sebgai fungsi control bunyi pada Jalan Cut Nyak Dien segmen 3, terdapat kombinasi pohon mahoni, cemara dan dikombinasikan dengan perdu. 
Segmen 4, penilaian pada segmen ini menunjukkan bahwa $65 \%$ dari 5 kriteria terpenuhi dan termasuk kedalam kategori sangat baik. Pada segmen ini kedua sisi jalan ditanami pohon dengan jarak cukup rapat dan memiliki massa daun padat. Pohon-pohon tersebut ditanam di dekat jalan. Pohon yang terdapat pada segmen ini yaitu pohon tanjung, mahoni, dan matoa. Tajuk-tajuk yang saling bersinggungan pohon ini menjadi penahan bunyi yang berasal dari kenderaan bermotor.

\section{Jalan Sudirman}

Segmen 1, penilaian pada segmen ini menunjukkan bahwa $75 \%$ dari 5 kriteria terpenuhi dan termasuk kedalam kategori baik. Median jalan ditanami pohon angsana dengan jarak cukup rapat dan daun rimbun. Antara satu pohon dengan pohon lainnya terdapat planting box yang ditanami perdu. Tajuk pohon angsana dapat menjadi barrier suara kenderaan bermotor. Planting box yang ditanami perdu juga berfungsi sebagai kontrol suara pada kedua ruas jalan yang berlainan arah.

Segmen 2, penilaian pada segmen ini menunjukkan bahwa 50\% dari 5 kriteria terpenuhi dan termasuk kedalam kategori sedang. Pada median ini ditanami pohon angsana dan rumput sebagai penutup tanah. Jalan ini tidak memiliki pohon pada kedua tepi jalan. Pada segmen ini tidak terdapat kombinasi tanaman. Tajuk pohon angasana yang cukup lebar dan daun yang rapat cukup dapat mengantisipasi bunyi kendaraan yang melewati ruas jalan ini.

Segmen 3, penilaian pada segmen ini menunjukkan bahwa 56,25\% dari 5 kriteria terpenuhi dan termasuk kedalam kategori sedang. Pada segmen ini median jalannya terdiri atas pohon angsana dan perdu. Walau terdiri beberapa lapis tanaman tetapi belum dapat efektif mengantisipasi bunyi kenderaan. Hal ini disebabkan penanaman perdu dan semak yang tidak kontinuitas. Segmen jalan yang ditanami pohon mahoni yang masih berumur muda dan jarak tanam tidak begitu rapat.

Segmen 4, penilaian pada segmen ini menunjukkan bahwa $75 \%$ dari 5 kriteria terpenuhi dan termasuk kedalam kategori baik. Pada segmen in terdapat beberapa 
lapis tanaman yang berupa kombinasi pohon, perdu dan penutup tanah. Pada kedua sisi jalan ditanami pohon mahoni, pohon bintaro, cemara lilin dan perdu. Tajuk yang saling bersinggungan dan juga massa daun yang padat dapat menjadi penghalang bunyi kenderaan ke bangunan kantor.

Segmen 5, penilaian pada segmen ini menunjukkan bahwa $75 \%$ dari 5 kriteria terpenuhi dan termasuk kedalam kategori baik. Pada segmen ini median jalan ditanami kombinasi pohon dan perdu. Pohon bintaro yang dikombinasikan dengan perdu dan penutup tanah menjadi bahan yang cukup mendukung dalam kontrol bunyi. Massa daun yang rapat dan ditanam dekat dengan jalan menjadi penempatan pohon mahoni di kedua sisi jalan menjadi barrier bagi suara kendaraan.

Segmen 6, penilaian pada segmen ini menunjukkan bahwa 62,5\% dari 5 kriteria terpenuhi dan termasuk kedalam kategori baik. Pada ruas jalan ini kedua sisi jalan ditanami pohon mahoni dan pada median jalannya ditanami pohon angsana. Tajuk antar pohon yang saling bersinggungan dan memiliki massa daun padat dapat menjadi kontrol bunyi kendaraan bermotor.

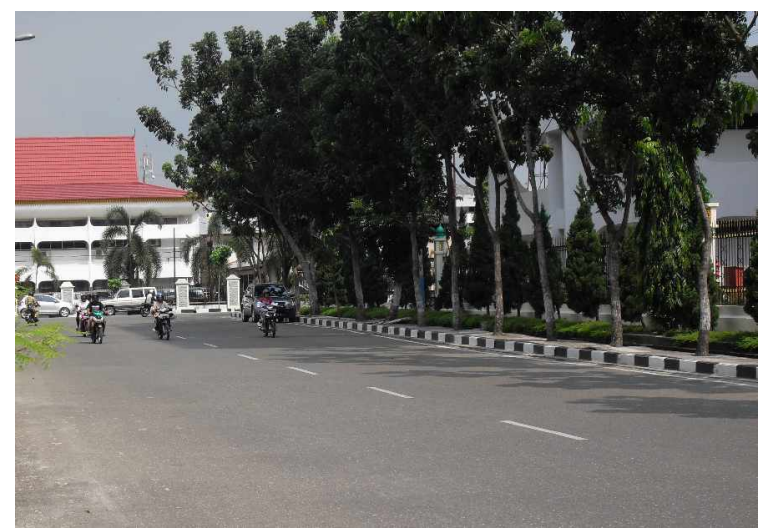

Gambar 23. Deretan Mahoni Kombinasi dengan Cemara dan Perdu sebagai Kontrol Bunyi di Kantor Gubernur Jalan Cut Nyak Dien

Segmen 7, penilaian pada segmen ini menunjukkan bahwa $75 \%$ dari 5 kriteria terpenuhi dan termasuk kedalam kategori baik. Median jalan ditanami beberapa lapis tanaman yang merupakan kombinasi pohon, perdu dan penutup tanah. Pohon palem dikombinasikan dengan perdu tinggi dan penutup tanah menjadi kontrol bunyi kendaraan. Kedua sisi jalan yang ditanami pohon mahoni dengan masa 
daun padat pun menjadi penghalang bunyi kendaraan bermotor dari jalan ke bangunan di sekitar jalan.

Segmen 8, penilaian pada segmen ini menunjukkan bahwa 62,5\% dari 5 kriteria terpenuhi dan termasuk kedalam kategori baik. Pada segmen ini median jalan terdiri dari palem, bougenvil, nusa indah yang ditanam dengan perdu dan penutup tanah. Massa daun yang padat dari beberapa lapis tanaman ini menjadi kontrol bunyi kedua jalan. Kedua sisi jalan yang ditanami pohon kelapa sawit dan pohon mahoni dengan tajuk saling bersinggungan dan massa daun padat menjadi penghalang suara kenderaan dan ditambah dengan adanya dinding penghalang pada satu sisi jalan.

\section{Jalan Gajah Mada}

Segmen 1, penilaian pada segmen ini menunjukkan bahwa $45 \%$ dari 5 kriteria terpenuhi dan termasuk kedalam kategori sedang. Pohon mahoni yang ditanam dekat jalan. Pohon mahoni ditanam dengan jarak cukup rapat di kedua sisi jalan. Pohon mahoni yang berumur muda belum dapat berfungsi maksimal sehingga bunyi berasal dari kenderaan belum dapat diatasi dengan baik.

\section{Jalan Diponegoro}

Segmen 1, penilaian pada segmen ini menunjukkan bahwa $80 \%$ dari 5 kriteria terpenuhi dan termasuk kedalam kategori sangat baik. Pada segmen ini pohon tanjung yang ditanam didekat tepi kedua jalan memiliki massa daun yang padat. Hal ini menjadi penahan bunyi dari kenderaan bermotor. Median jalan yang ditanami bintaro, palem dan perdu juga menjadi kontrol terhadap suara kenderaan. Pada segmen ini kontrol bunyi dapat berjalan dengan sangat baik.

Segmen 2, penilaian pada segmen ini menunjukkan bahwa $60 \%$ dari 4 kriteria terpenuhi dan termasuk kedalam kategori baik. Median jalan yang ditanami kombinasi tanaman (pohon bintaro, palem, perdu) yang berlapis menjadi penahan suara kenderaan bermotor. Pada satu sisi jalan planting box yang berisi bougenvil juga dapat dimanfaatkan sebagai penahan suara kenderaan.

Segmen 3, penilaian pada segmen ini menunjukkan bahwa 65\% dari 5 kriteria terpenuhi dan termasuk kedalam kategori baik. Ruas jalan ini median jalannya masih ditanami kombinasi pohon bintaro, palem dengan perdu dan penutup tanah. 
Pada satu sisi jalan ditanami pohon glodogan tiang yang ditanam dekat jalan, tajuk saling bersinggungan dan massa daun padat. Tajuk pohon glodogan ini dapat menjadi kontrol suara kenderaan. Pada satu sisi jalan yang lain ditanami pohon mahoni yang masih berumur muda.

Segmen 4, penilaian pada segmen ini menunjukkan bahwa $65 \%$ dari 5 kriteria terpenuhi dan termasuk kedalam kategori baik. Berbagai macam pohon ditanam di kedua sisi jalan. Pohon yang ditanam dekat jalan seperti pohon mahoni, glodogan tiang, dan tanjung. Pohon-pohon ini ditanam dengan jarak rapat dan massa daun rapat dapat menjadi pengahalang bunyi kenderaan. Median jalan yang ditanami pohon bintaro dan palem dikombinasikan dengan perdu dan penutup tanah pun dapat memberikan manfaat sebagai kontrol bunyi.

Tanaman yang dapat digunakan sebagai peredam bising yaitu tanjung, krei payung, teh-tehan pangkas, kembang sepatu, bougenvil, dan oleander (Dinas PU Direktorat Bina Marga, 1996). Hasil pengukuran Hidayat (2008) menunjukkan bahwa kerapatan daun berperan penting dalam meredam kebisingan. Tanaman dengan kerapatan daun lebih tinggi dapat meredamkebisingan lebih baik pula. Menurut Carpenter et al. (1975), tingkat kebisingan yang dapat direduksi oleh tanaman tergantung pada kepadatan tanaman dan lebar atau ketebalan penanaman dan semakin dekat ke sumber kebisingan akan semakin efektif fungsinya dalam meredam kebisingan.

\section{Fungsi Kontrol Polusi}

Kriteria tanaman sebagai fungsi kontrol polusi yaitu, ditanam kontinyu, tajuk bersinggungan, daun rimbun, kombinasi pohon sedang $<15 \mathrm{~m}$ dan semak, berkapasitas tinggi menggurangi polutan, toleran polutan. Penilaian fungsi kontrol polusi dapat dilihat pada Tabel 16 .

Tabel 16. Penilaian Fungsi Kontrol Polusi

\begin{tabular}{|c|c|c|c|c|c|c|c|c|c|}
\hline \multirow[t]{2}{*}{ Nama Jalan } & \multirow[t]{2}{*}{ Segmen } & \multicolumn{6}{|c|}{ Kriteria Penilaian } & \multirow{2}{*}{$\begin{array}{l}\text { Skor } \\
(\%)\end{array}$} & \multirow[t]{2}{*}{ Kategori } \\
\hline & & 1 & 2 & 3 & 4 & 5 & 6 & & \\
\hline \multirow{4}{*}{$\begin{array}{ll}\text { Cut } & \text { Nyak } \\
\text { Dien } & \end{array}$} & 1 & 3 & 2 & 2 & 2 & 3 & 3 & 62,5 & Baik \\
\hline & 2 & 3 & 1 & 1 & 1 & 2 & 2 & 41,7 & Sedang \\
\hline & 3 & 3 & 2 & 2 & 3 & 2 & 3 & 62,5 & Sedang \\
\hline & 4 & 3 & 3 & 3 & 3 & 3 & 3 & 75 & Baik \\
\hline \multicolumn{8}{|l|}{ Total Rata-rata } & 60,4 & Sedang \\
\hline \multirow[t]{2}{*}{ Sudirman } & 1 & 3 & 3 & 3 & 3 & 2 & 3 & 70,8 & Baik \\
\hline & 2 & 3 & 4 & 3 & 1 & 3 & 3 & 70,8 & Baik \\
\hline
\end{tabular}


Tabel 16. (Lanjutan)

\begin{tabular}{|c|c|c|c|c|c|c|c|c|c|}
\hline \multirow[t]{2}{*}{ Nama Jalan } & \multirow[t]{2}{*}{ Segmen } & \multicolumn{6}{|c|}{ Kriteria Penilaian } & \multirow{2}{*}{$\begin{array}{c}\text { Skor } \\
(\%)\end{array}$} & \multirow[t]{2}{*}{ Kategori } \\
\hline & & 1 & 2 & 3 & 4 & 5 & 6 & & \\
\hline & 3 & 3 & 4 & 3 & 1 & 3 & 3 & 70,8 & Baik \\
\hline & 4 & 3 & 2 & 2 & 3 & 2 & 2 & 58,3 & Sedang \\
\hline & 5 & 3 & 2 & 3 & 3 & 2 & 3 & 66,7 & Baik \\
\hline & 6 & 4 & 4 & 3 & 2 & 3 & 3 & 79,2 & Baik \\
\hline & 7 & 3 & 3 & 3 & 4 & 2 & 3 & 75 & Baik \\
\hline & 8 & 3 & 2 & 3 & 2 & 2 & 2 & 58,3 & Sedang \\
\hline \multicolumn{8}{|c|}{ Total Rata-rata } & 68,7 & Baik \\
\hline $\begin{array}{l}\text { Gajah } \\
\text { Mada }\end{array}$ & 1 & 3 & 2 & 2 & 1 & 2 & 2 & 50 & Sedang \\
\hline \multicolumn{8}{|c|}{ Total Rata-rata } & 50 & Sedang \\
\hline \multirow[t]{4}{*}{ Diponegoro } & 1 & 3 & 3 & 3 & 3 & 2 & 2 & 66,7 & Baik \\
\hline & 2 & 3 & 1 & 2 & 2 & 3 & 2 & 54,2 & Sedang \\
\hline & 3 & 3 & 4 & 3 & 2 & 3 & 3 & 75 & Sedang \\
\hline & 4 & 3 & 3 & 3 & 2 & 3 & 2 & 66,7 & Baik \\
\hline \multicolumn{8}{|c|}{ Total Rata-rata } & 65,65 & Baik \\
\hline \multicolumn{10}{|l|}{ Keterangan : } \\
\hline
\end{tabular}

\section{Jalan Cut Nyak Dien}

Segmen 1, penilaian pada segmen ini menunjukkan bahwa 62,5\% dari 6 kriteria terpenuhi dan termasuk kedalam kategori baik. Kedua sisi jalan ditanami mahoni secara kontiniu. Pada median jalan ditanami kombinasi pohon dan semak yang memiliki daun rimbun. Palem merupakan tanaman dengan daya serap $\mathrm{NO}_{2}$ sedang dan pohon mahoni merupakan pohon yang dapat menyerap $\mathrm{NO}_{2}$ dan polutan lainnya. Secara umum kriteria kontrol polusi dapat dipenuhi dengan baik pada segmen ini.

Segmen 2, penilaian pada segmen ini menunjukkan bahwa 41,7\% dari 6 kriteria terpenuhi dan termasuk kedalam kategori sedang. Pada segmen ini kedua median trotoar ditanami palem raja dan mahoni berselingan. Tanaman ini ditanam kontiniu tetapi mahoni masih berumur muda sehingga daun tidak rimbun. Pada jalan ini juga tidak terdapat kombinasi pohon dan perdu sehingga kontrol polusi kurang. Kemampuan pohon mahoni untuk menyerap polutan dan $\mathrm{NO}_{2}$ cukup membantu, apabila nantinya pohon mahoni ini tumbuh dengan subur, bercabang baik dan daun rimbun. Palem raja memiliki daya serap $\mathrm{NO}_{2}$ rendah.

Segmen 3, penilaian pada segmen ini menunjukkan bahwa 62,5\% dari 6 kriteria terpenuhi dan termasuk kedalam kategori baik. Pada segmen ini kedua sisi jalan 
ditanam pohon mahoni secara kontiniu. Pada satu sisi jalan juga ditanami cemara lilin. Tajuk pohon saling bersinggungan dan memiliki daun rimbun. Pada median jalan ditanami kombinasi palem, kembang merak, cassia glauca dan perdu. Mahoni merupakan pohon yang dapat menyerap $\mathrm{NO}_{2}$ dan polutan. Pada median ditanami kembang merak yang memiliki daya serap $\mathrm{NO}_{2}$ dan polutan yang baik dikombinasikan dengan palem putri yang memiliki kemampuan menyerap $\mathrm{NO}_{2}$ sedang. Adanya perkerasan pada median jalan dapat menguranggi fungsi kontrol polusi.

Segmen 4, penilaian pada segmen ini menunjukkan bahwa $75 \%$ dari 6 kriteria terpenuhi dan termasuk kedalam kategori baik. Pada segmen ini tajuk pohon pada median trotoar saling bersinggungan dan rimbun. Hal ini sangat membantu dalam Kontrol polusi. Penanaman pohon seperti tanjung, matoa, dan mahoni berkesinambungan disepanjang jalan ini dapat menyerap polutan dan $\mathrm{NO}_{2}$ dan tanaman tersebut dapat bertahan dari polutan yang berasal dari kenderaan.

\section{Jalan Sudirman}

Segmen 1, penilaian pada segmen ini menunjukkan bahwa 70,8\% dari 6 kriteria terpenuhi dan termasuk kedalam kategori baik. Penanaman pohon angsana secara kontiniu di sepanjang median jalan dengan jarak rapat dan tajuk saling bersinggungan serta memiliki daun rimbun. Hal ini dapat menjadi kontrol polusi pada segmen ini. Hal ini juga diperkuat dengan penempatan planting box diantara pohon angsana yang ditanami perdu. Hal ini juga cukup membantu mengatasi polusi dari kenderaan bermotor. Walaupun angsana dan bakung memiliki daya serap $\mathrm{NO}_{2}$ dan polutan sedang.

Segmen 2, penilaian pada segmen ini menunjukkan bahwa 70,8\% dari 6 kriteria terpenuhi dan termasuk kedalam kategori baik. Pada segmen ini pohon angsana berperan besar dalam kontrol polusi sebab pada median jalan hanya ditanami pohon angsana dan rumput. Pohon angsana ditanam rapat, tajuk bersinggungan, dan daun rimbun sangat membantu dalam menyerap polusi. Pohon angsana dapat menyerap $\mathrm{NO}_{2}$ dan polutan dengan baik.

Segmen 3, penilaian pada segmen ini menunjukkan bahwa 70,8\% dari 6 kriteria terpenuhi dan termasuk kedalam kategori baik. Penanaman pohon angsana dengan 
perdu (perdu tidak ditanam kontiniu) pada median jalan, tajuk pohon bersinggungan dan daun rimbun. Angsana dapat menjadi pohon yang dapat menyerap polutan.

Segmen 4, penilaian pada segmen ini menunjukkan bahwa 58,3\% dari 6 kriteria terpenuhi dan termasuk kedalam kategori sedang. Pada segmen ini tidak terdapat pohon (mahoni dan angsana) yang tajuknya tidak saling bersinggungan sebab jarak tanam yang tidak rapat dan pohon berumur muda. Pada median lebih didominasi perdu dan penutup tanah. Perdu seperti asoka dapat menyerap polutan. Terdapat cemara lilin yang ditanam rapat di depan kantor Gubernur dan dapat menjadi penyerap polutan.

Segmen 5, penilaian pada segmen ini menunjukkan bahwa 66,7\% dari 6 kriteria terpenuhi dan termasuk kedalam kategori baik. Pada segmen ini median jalan ditanami kombinasi pohon dan semak. Pohon bintaro yang ditanam dengan jarak rapat, tajuk saling bersinggungan dan bermassa daun rimbun. Pada median trotoar ditanami secara kontiniu. Pohon mahoni cukup baik menyerap polutan dan $\mathrm{NO}_{2}$. Penanaman tanaman didekat jalan menjadi kontrol polusi yang baik.

Segmen 6, penilaian pada segmen ini menunjukkan bahwa 79,2\% dari 6 kriteria terpenuhi dan termasuk kedalam kategori baik. Pada segmen ini median jalan ditanami angsana yang memiliki tajuk bersinggungan, berdaun rimbun, ditanam rapat dan kontiniu sepanjang median jalan. Pada median trotoar ditanami pohon mahoni dengan jarak rapat dan tajuk bersinggungan. Kemampuan mahoni dan angsana dalam meyerap polutan dan $\mathrm{NO}_{2}$ sangat membantu dalam kontrol polusi di segmen ini. Pada Gambar 24 dapat dilihat fungsi pohon sebagai control polusi pada Jalan Sudirman segmen 6.

Segmen 7, penilaian pada segmen ini menunjukkan bahwa 75\% dari 6 kriteria terpenuhi dan termasuk kedalam kategori baik. Pada segmen ini median jalan ditanami pohon palem raja dan perdu. Perdu memiliki daun yang rimbun. Kedua sisi jalan ditanami pohon mahoni dengan tajuk saling bersinggungan, daun rimbun. Peletakkan perdu pada median jalan dan pohon mahoni secara kontiniu di sisi jalan membantu dalam menggontrol polusi. Pohon mahoni dan kembang merak, memiliki kemampuan baik dalam menyerap $\mathrm{NO}_{2}$ dan polutan sedangkan palem raja termasuk kategori sedang. 
Segmen 8, penilaian pada segmen ini menunjukkan bahwa 58,3\% dari 6 kriteria terpenuhi dan termasuk kedalam kategori sedang. Pada segmen ini median jalan yang ditanami palem merah, bougenvil, semak, dan juga nusa indah. Kedua sisi jalan ditanami beberapa pohon mahoni dan kelapa sawit. Kelapa sawit memiliki kemapuan rendah dalam menyerap polutan. Jadi polusi dari kenderaan ditanggulangi melalui perdu dan pohon yang ditanam rapat di median jalan.

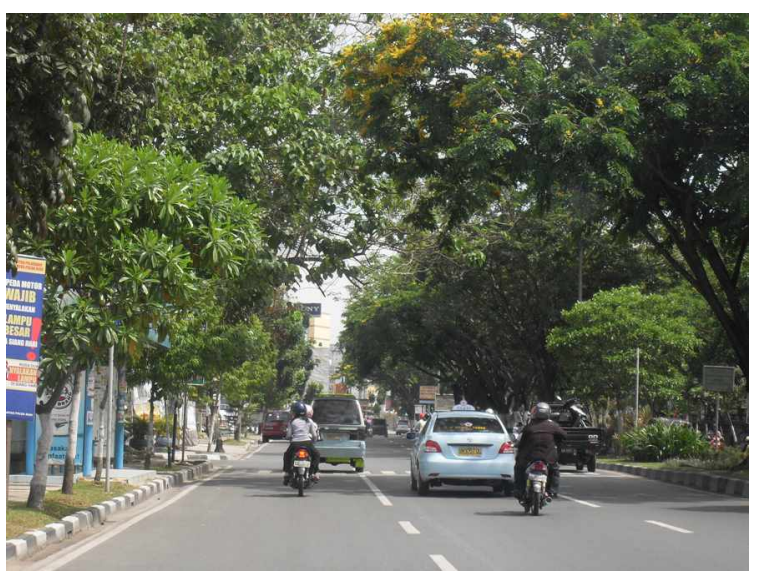

Gambar 24. Pohon Massal Campuran Kombinasi dengan Perdu Sebagai Fungsi Kontrol Polusi di Jalan Sudirman

\section{Jalan Gajah Mada}

Segmen 1, penilaian pada segmen ini menunjukkan bahwa 50\% dari 6 kriteria terpenuhi dan termasuk kedalam kategori sedang. Pada segmen jalan ini tidak memiliki median jalan yang utuh, hanya terdapat pohon mahoni ditanam pada median trotoar secara kontiniu. Pohon mahoni yang masih berumur muda sehingga daun tidak rimbun dan tajuk belum bersinggungan. Selain itu juga terdapat planting box ditanami pangkas kuning dan mawar, tetapi planting box ini tidak cukup membantu dalam mengkontrol polusi. Pohon mahoni memiliki kemampuan menyerap $\mathrm{NO}_{2}$ dan polutan dengan baik, diharapkan pertumbuhan mahoni dapat baik sehingga dapat menjadi kontrol polusi yang baik pada ruas jalan ini.

\section{Jalan Diponegoro}

Segmen 1, penilaian pada segmen ini menunjukkan bahwa 66,7\% dari 6 kriteria terpenuhi dan termasuk kedalam kategori baik. Pada segmen ini kedua ruas jalan 
ditanami pohon tanjung dengan jarak rapat, tajuk bersinggungan, daun rimbun dan pohon tanjung termasuk kedalam tanaman penyerap $\mathrm{NO}_{2}$ dan polutan sedang. Penanaman pohon secara kontiniu sepanjang tepi jalan menjadi penyerap polusi kenderaan yang baik. Pada median jalan terdapat kombinasi penanaman palem, bintaro dan perdu, secara kontiniu, memiliki daun rimbun, toleran polutan dan dapat mengurangi polutan yang berasal dari kenderaan bermotor.

Segmen 2, penilaian pada segmen ini menunjukkan bahwa 54,2\% dari 6 kriteria terpenuhi dan termasuk kedalam kategori sedang. Pada segmen ini kontrol polusi berkategori sedang sebab pada kedua sisi jalan tidak terdapat pohon yang tajuknya bersinggungan dan tidak rimbun. Pada satu sisi jalan ditanami bougenvil yang diletakkan pada planting box. Bougenvil yang baik dalam menyerap polutan dan $\mathrm{NO}_{2}$ membantu dalam mengurangi polutan pada ruas jalan ini. Pada segmen ini terdapat kombinasi palem, bintaro dan perdu pada median yang juga membantu dalam penyerapan polutan.

Segmen 3, penilaian pada segmen ini menunjukkan bahwa $75 \%$ dari 6 kriteria terpenuhi dan termasuk kedalam kategori baik. Median jalan ditanami pohon dan perdu, daun rimbun, dapat mengurangi polutan pada jalan. Pada satu sisi jalan ditanami pohon mahoni secara kontiniu dengan jarak tanam rapat, sedangkan sisi jalan yang lain ditanami pohon glodogan bulat dengan tajuk saling bersinggungan, daun rimbun dan menjadi penyerap polutan pada jalan. Median jalan ditanam kombinasi poalem, bintaro dan perdu.

Segmen 4, penilaian pada segmen ini menunjukkan bahwa 66,7\% dari 6 kriteria terpenuhi dan termasuk kedalam kategori baik. Pada segmen ini median jalan masih ditanami palem, bintaro dan perdu dengan daun rimbun, jarak tanam rapat. Hal ini sangat membantu dalam penyerapan polutan. Kedua sisi jalan ditanami bermacam jenis pohon seperti mahoni, tanjung, dan glodogan tiang. Tajuk pohon saling bersinggungan dan menyerap polutan.

Penanaman vegetasi di sepanjng tepi jalan diharapkan mampu menyerap polusi yang disebabkan oleh kenderaan bermotor, sehingga lingkungan jalan menjadi segar dan nyaman (Carpenter et al., 1975). Tanaman yang dianjurkan sebagai penyerap polusi oleh Dinas PU Direktorat Bina Marga (1996) yaitu, angsana, akasia, oleander, bougenvil, teh-tehan pangkas. Menurut Aris (2005), 
hasil perhitungannya memperlihatkan bahwa kondisi jarak tanam yang rapat serta sebagian besar tanaman yang dapat menyerap polusi ini bermassa daun rapat. Menurut Nasrullah (1997), tanaman angsana yang digunkan sebagai elemen lanskap di Jakarta dan Bogor termasuk tanaman dengan serapan $\mathrm{NO}_{2}$ yang tidak tinggi. Tanaman yang tahan terhadap polutan dapat dilihat pada Lampiran 2.

\section{Fungsi Pemberi Identias}

Tabel 17. Penilaian Fungsi Pemberi Identitas

\begin{tabular}{|c|c|c|c|c|c|c|c|}
\hline \multirow[t]{2}{*}{ Nama Jalan } & \multirow[t]{2}{*}{ Segmen } & \multicolumn{4}{|c|}{ Kriteria Penilaian } & \multirow{2}{*}{$\begin{array}{c}\text { Skor } \\
(\%)\end{array}$} & \multirow[t]{2}{*}{ Kategori } \\
\hline & & 1 & 2 & 3 & 4 & & \\
\hline \multirow{4}{*}{$\begin{array}{ll}\text { Cut } & \text { Nyak } \\
\text { Dien } & \end{array}$} & 1 & 2 & 3 & 2 & 2 & 56,3 & Sedang \\
\hline & 2 & 3 & 2 & 2 & 2 & 56,3 & Sedang \\
\hline & 3 & 3 & 2 & 2 & 3 & 62,5 & Baik \\
\hline & 4 & 3 & 2 & 3 & 3 & 68,8 & Baik \\
\hline \multicolumn{6}{|l|}{ Total Rata-rata } & 61 & Baik \\
\hline \multirow[t]{8}{*}{ Sudirman } & 1 & 3 & 3 & 3 & 2 & 68,8 & Baik \\
\hline & 2 & 4 & 3 & 3 & 3 & 81,3 & Sangat Baik \\
\hline & 3 & 4 & 3 & 3 & 3 & 81,3 & Sangat Baik \\
\hline & 4 & 2 & 3 & 3 & 3 & 68,8 & Baik \\
\hline & 5 & 3 & 3 & 3 & 3 & 75 & Baik \\
\hline & 6 & 4 & 3 & 4 & 3 & 87,5 & Sangat Baik \\
\hline & 7 & 3 & 3 & 4 & 3 & 81,3 & Sangat Baik \\
\hline & 8 & 3 & 3 & 3 & 3 & 75 & Baik \\
\hline \multicolumn{6}{|l|}{ Total Rata-rata } & 77,3 & Baik \\
\hline Gajah Mada & 1 & 3 & 2 & 2 & 3 & 62,5 & Baik \\
\hline \multicolumn{6}{|l|}{ Total Rata-rata } & 62,5 & Baik \\
\hline \multirow[t]{4}{*}{ Diponegoro } & 1 & 3 & 4 & 3 & 3 & 81,3 & Sangat Baik \\
\hline & 2 & 2 & 2 & 3 & 3 & 62,5 & Baik \\
\hline & 3 & 3 & 3 & 3 & 3 & 75 & Baik \\
\hline & 4 & 3 & 4 & 3 & 3 & 81,3 & Sangat Baik \\
\hline \multicolumn{6}{|l|}{ Total Rata-rata } & 75 & Baik \\
\hline \multicolumn{8}{|l|}{ Keterangan : } \\
\hline
\end{tabular}

Kriteria tanaman berfungsi sebagai pemberi identitas yaitu, mempunyai ciri khas kuat, tanaman asli daerah, tanaman memiliki nilai sejarah, pola menarik. Penilaian tanaman berfungsi pemberi identitas dapat dilihat pada Tabel 17.

\section{Jalan Cut Nyak Dien}

Segmen 1, penilaian pada segmen ini menunjukkan bahwa 56,3\% dari 4 kriteria terpenuhi dan termasuk kedalam kategori sedang. Pada segmen jalan ini pada kedua tepi jalan ditanami pohon mahoni. Pohon mahoni ini masih bermur muda sehingga belum dapat memberikan suatu identitas tertentu. Median jalan yang 
ditanami palem dengan kombinasi perdu yang dibuat taman pada median jalan sehingga membentuk suatu pemandangan yang menarik.

Segmen 2, penilaian pada segmen ini menunjukkan bahwa 56,3\% dari 4 kriteria terpenuhi dan termasuk kedalam kategori sedang. Pada jalan ini ditanami dengan pohon palem yang telah tumbuh lama. Palem menjadi identitas jalan ini. Pohon palem yang menjulang tinggi menjadi identitas pada jalan ini.

Segmen 3, penilaian pada segmen ini menunjukkan bahwa 62,5\% dari 4 kriteria terpenuhi dan termasuk kedalam kategori baik. Pada jalan ini terdapat pohon mahoni yang telah tua. Pohon mahoni yang rindang menjadi ciri khas pada jalan ini.

Segmen 4, penilaian pada segmen ini menunjukkan bahwa 68,8\% dari 4 kriteria terpenuhi dan termasuk kedalam kategori baik. Pada segmen ini terdapat berbagai macam pohon seperti tanjung, mahoni, dan matoa. Pada umumnya didominasi oleh pohon tanjung yang merupakan ciri khas, memiliki nilai sejarah, tanaman asli daerah dan memiliki tajuk yang menarik. Pada ruas jalan di samping BI dan kantor kehutanan yang ditanami dengan pohon tanjung yang ditanam rapat.

\section{Jalan Sudirman}

Segmen 1, penilaian pada segmen ini menunjukkan bahwa 68,8\% dari 6 kriteria terpenuhi dan termasuk kedalam kategori baik. Penanaman pohon tua angsana sepanjang jalan ini. Pohon angsana memilki tajuk spreading saling bersinggungan memberikan ciri khas kuat jalan ini. Peletakkan planting box yang ditanami bakung memberikan ciri khas tersendiri segmen jalan ini.

Segmen 2, penilaian pada segmen ini menunjukkan bahwa 79,2\% dari 6 kriteria terpenuhi dan termasuk kedalam kategori baik. Pada segmen ini pohon tua yang memiliki sejarah dan merupakan tanaman asli yaitu pohon angsana. Peletakkan pohon angsana di sepanjang segmen ini memberikan pemandangan yang bagus dan menarik. Pohon angsana ini merupakan ciri khas yang kuat.

Segmen 3, penilaian pada segmen ini menunjukkan bahwa 81,3\% dari 4 kriteria terpenuhi dan termasuk kedalam kategori sangat baik. Pada segmen ini pohon angsana yang memiliki tajuk spreading saling bersinggungan. Pohon angsana 
dikombinasikan dengan perdu dan penutup tanah yang ditanam dengan pola yang menarik. Hal ini menjadi ciri khas dan identitas pada segmen jalan ini.

Segmen 4, penilaian pada segmen ini menunjukkan bahwa 81,3\% dari 4 kriteria terpenuhi dan termasuk kedalam kategori sangat baik. Sepanjang jalan pada jalan ini terdapat median yang ditanami cemara udang dan perdu yang dibuat dengan berbagai pola menarik membentuk taman. Bentukan taman sepanjang median jalan ini menjadi identitas dan ciri khas jalan ini.

Segmen 5, penilaian pada segmen ini menunjukkan bahwa $75 \%$ dari 4 kriteria terpenuhi dan termasuk kedalam kategori baik. Segmen ini adalah segmen yang median jalannya ditanami pohon bintaro, perdu dan penutup tanah. Kombinasi ketiga tanaman dibentuk menjadi pola yang menarik.

Segmen 6, penilaian pada segmen ini menunjukkan bahwa 87,5\% dari 4 kriteria terpenuhi dan termasuk kedalam kategori sangat baik. Barisan pohon tua angsana pada median jalan dan pohon mahoni disepanjang tepi jalan memberikan identitas tersendiri. Tajuk saling bersinggungan memberikan pemandangan yang menarik. Pada Gambar 25 dapat dilihat fungsi pohon sebgai pemberi identitas, pohon angsana memilki bunga berwarna kuning memeberikan daya tarik dan warna kuning mewakili warna kerajaan melayu.

Segmen 7, penilaian pada segmen ini menunjukkan bahwa $81,3 \%$ dari 4 kriteria terpenuhi dan termasuk kedalam kategori sangat baik. Pada segmen ini pohon palem yang dikombinasikan dengan perdu dan penutup tanah merupakan ciri khas yang kuat. Pola perdu dan penutup tanah yang menarik membentuk taman pada median jalan. Pohon mahoni tua berbaris sepanjang tepi jalan pada segmen jalan ini.

Segmen 8, penilaian pada segmen ini menunjukkan bahwa $75 \%$ dari 4 kriteria terpenuhi dan termasuk kedalam kategori baik. Kelapa sawit berbaris sepanjang sisi jalan. Pohon sawit yang merupakan pohon asli daerah yang digunakan sebagai sumber penghasilan daerah. Median jalan yang ditanami nusa indah, boungenvil dan palem merah dengan pola yang menarik dan teratur. 


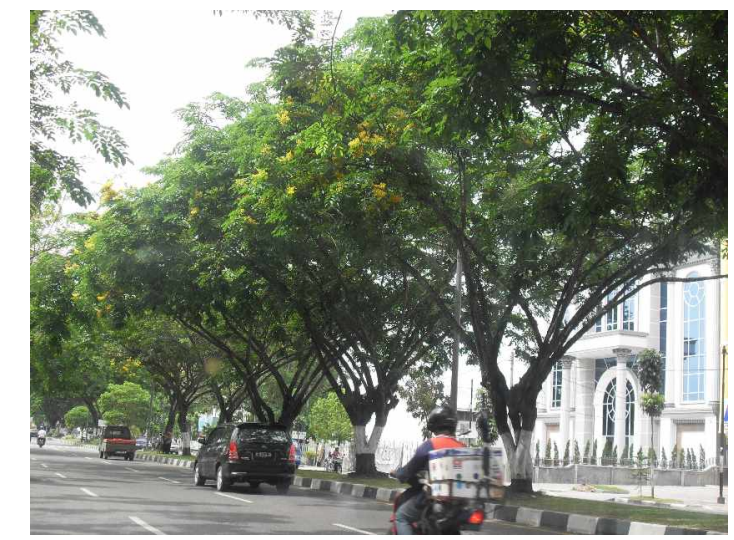

Gambar 25. Deretan Pohon Angsana Menjadi Identitas Pada Jalan Sudirman

\section{Jalan Gajah Mada}

Segmen 1, penilaian pada segmen ini menunjukkan bahwa 62,5\% dari 6 kriteria terpenuhi dan termasuk kedalam kategori baik. Deretan pohon mahoni menjadi tanda pada jalan ini. Pada jalan masuk terdapat median jalan yang ditanami perdu dan ditata membentuk taman. Hal ini memberikan pemandangan menarik.

\section{Jalan Diponegoro}

Segmen 1, penilaian pada segmen ini menunjukkan bahwa 81,3\% dari 4 kriteria terpenuhi dan termasuk kedalam kategori sangat baik. Pada segmen ini pohon tanjung menjadi ciri khas kuat. Pohon yang merupakan tanaman asli daerah dan memiliki nilai sejarah. Pohon tanjung ditanam berbaris sepanjang jalan memberikan pemandangan yang menarik. Median jalan yang ditanami palem, bintaro dan perdu yang membentuk pola seperti taman memberikan visual yang baik dan menjadi identitas sepanjang jalur ini.

Segmen 2, penilaian pada segmen ini menunjukkan bahwa 62,5\% dari 4 kriteria terpenuhi dan termasuk kedalam kategori baik. Peletakan planting box sepanjang tepi jalan pada satu sisi jalan merupakan ciri khas pada jalan ini. Bougenvil yang ditanam pada planting box merupakan tanaman yang menjadi daya tarik pada jalan ini dengan warna bunganya.

Segmen 3, penilaian pada segmen ini menunjukkan bahwa $75 \%$ dari 4 kriteria terpenuhi dan termasuk kedalam kategori baik. Glodogan bulat dengan tajuknya yang saling bersinggungan memberikan gambaran berbeda dan menjadi ciri khas 
pada segmen jalan ini. Median jalan memiliki pola penanaman menarik membentuk taman pada median jalan.

Segmen 4, penilaian pada segmen ini menunjukkan bahwa $81,3 \%$ dari 4 kriteria terpenuhi dan termasuk kedalam kategori sangat baik. Pohon tanjung yang merupakan tanaman asli dan merupakan ciri khas serta memiliki nilai sejarah menjadi daya tarik kuat pada jalan ini. Pohon tanjung ditanam pada satu sisi jalan. Pada sisi jalan yang lain terdapat penanaman mahoni sepanjang tepi jalan.

\section{Penilaian Seluruh Aspek Fungsi Tanaman Lanskap Jalan Pada Setiap Segmen Jalan}

Penjabaran nilai pada 7 aspek fungsi tanaman dirangkum pada Tabel 18. Setelah dilakukan pengabungan nilai didapat segmen jalan yang masuk kedalam kategori sangat baik yaitu : Jalan Sudirman segmen 6 (81,9\%); kategori baik yaitu : Jalan Cut Nyak Dien segmen 1 (62\%), 3 (65.2\%), dan 4 (72,1\%), Jalan Sudirman segmen 1 (75,1\%), 2 (78,9\%), 3 (78,9\%), 4 (66,4\%), $5(72,6 \%), 7$ (76,8\%), 8 (70,5\%), Jalan Diponegoro segmen 1 (76,4\%), $3(72,7 \%)$, dan 4 (71,9\%); dan kategori sedang yaitu: Jalan Cut Nyak Dien segmen 2 (49,5\%), Jalan Gajah Mada segmen 1 (59,4\%), dan Jalan Diponegoro segmen 2 (59,6\%).

Dari hasil diatas dapat dilihat bahwa umumnya jalan berkategori baik yaitu sebanyak 13 segmen jalan, kategori sangat baik 1 segmen dan kategori sedang 3 segmen. Tiap fungsi memiliki pemenuhan rata-rata penilaian antara 64,5\%-77\%, ini termasuk kedalam kategori baik. Tata hijau pada Jalan Cut Nyak Dien, Jalan Sudirman, dan Jalan Diponegoro termasuk kategori baik dalam segi fungsional dan Jalan Gajah Mada termasuk kategori sedang. Hasil ini menunjukkan bahwa tanaman berfungsi besar dalam mengendalikan lingkungan jalan. Pada beberapa segmen jalan masih diperlukan perbaikan agar tercipta keadaan aman dan nyaman bagi pengguna jalan. 
Tabel 18. Penilaian Seluruh Aspek Fungsi Tanaman Lanskap Jalan

\begin{tabular}{|c|c|c|c|c|c|c|c|c|c|c|}
\hline \multirow[t]{2}{*}{ Jalan } & \multirow[t]{2}{*}{ Segmen } & \multicolumn{7}{|c|}{ Fungsi Tanaman Lanskap Jalan (\%) } & \multirow{2}{*}{$\begin{array}{c}\text { Total Penilaian } \\
(\%)\end{array}$} & \multirow[t]{2}{*}{ Kategori } \\
\hline & & 1 & 2 & 3 & 4 & 5 & 6 & 7 & & \\
\hline \multirow{4}{*}{$\begin{array}{ll}\text { Cut } & \text { Nyak } \\
\text { Dien } & \end{array}$} & 1 & 66,7 & 62,5 & 62,5 & 56,3 & 62,5 & 58,3 & 65 & 62 & Baik \\
\hline & 2 & 79,2 & 56,3 & 41,7 & 56,3 & 56,3 & 58,3 & 55 & 49,5 & Sedang \\
\hline & 3 & 75 & 75 & 58,3 & 62,5 & 62,5 & 58,3 & 65 & 65,2 & Baik \\
\hline & 4 & 83,3 & 81,3 & 70,8 & 68,8 & 68,8 & 66,7 & 65 & 72,1 & Baik \\
\hline \multicolumn{9}{|l|}{ Total Rata-rata } & 62 & Baik \\
\hline \multirow[t]{8}{*}{ Sudirman } & 1 & 83,3 & 75 & 83,3 & 68,8 & 75 & 75 & 65 & 75,1 & Baik \\
\hline & 2 & 91,7 & 87,5 & 95,8 & 81,3 & 62,5 & 58,3 & 75 & 78,9 & Baik \\
\hline & 3 & 87,5 & 87,5 & 95,8 & 81,3 & 75 & 75 & 50 & 78,9 & Baik \\
\hline & 4 & 58,3 & 68,8 & 62,5 & 68,8 & 75 & 75 & 56,25 & 66,4 & Baik \\
\hline & 5 & 70,8 & $75 \%$ & 62,5 & 75 & 75 & 75 & 75 & 72,6 & Baik \\
\hline & 6 & 87,5 & 81,3 & 91,7 & 87,5 & 75 & 75 & 75 & 81,9 & Sangat Baik \\
\hline & 7 & 79,2 & 75 & 75 & 81,3 & 81,3 & 83,3 & 62,5 & 76,8 & Baik \\
\hline & 8 & 83,3 & 68,8 & 62,5 & 75 & 62,5 & 66,7 & 75 & 70,5 & Baik \\
\hline \multicolumn{9}{|c|}{ Total Rata-rata } & 75,25 & Baik \\
\hline Gajah Mada & 1 & 75 & 68,8 & 58,3 & 62,5 & 43,7 & 45 & 62,5 & 59,4 & Sedang \\
\hline \multicolumn{9}{|c|}{ Total Rata-rata } & 59,4 & Sedang \\
\hline \multirow[t]{4}{*}{ Diponegoro } & 1 & 75 & 75 & 83,3 & 81,3 & 75 & 80 & 65 & 76,4 & Baik \\
\hline & 2 & 70,8 & 62,5 & 50 & 62,5 & 56,3 & 60 & 55 & 59,6 & Sedang \\
\hline & 3 & 75 & 75 & 79,2 & 75 & 75 & 65 & 65 & 72,7 & Baik \\
\hline & 4 & 66,7 & 75 & 75 & 81,3 & 75 & 65 & 65 & 71,9 & Baik \\
\hline \multicolumn{9}{|c|}{ Total Rata-rata } & 70,25 & Baik \\
\hline Rata-rata aspel & fungsi (\%) & 77 & 73 & 71 & 72 & 68 & 67 & 64,5 & & \\
\hline
\end{tabular}

5 : Fungsi Kontrol Silau Matahari

6 : Fungsi Kontrol Bunyi

7 : Fungsi Kontrol Polusi
Penilaian :

Sangat Baik bila $/ 81 \%$

Baik bila $61-80 \%$

Sedang bila $41-60 \%$

Buruk bila [ $40 \%$ 


\section{Penilaian Kualitas Estetika Tanaman Lanskap Jalan Nilai SBE Tata Hijau Sesuai Kategori Penyusunan Tanaman}

Setelah dilakukan pegumpulan data pengisian kuesioner dan diolah menghasilkan nilai SBE untuk tiap foto lanskap dari tiga kategori penyusunan penataan tanaman. Nilai Z dan SBE tiap foto dari ketiga kategori dapat dilihat pada Lampiran 3. Pada Gambar 26 dapat dilihat lanskap dengan niali SBE terendah dan Gambar 27 dapat dilihat lanskap dengan nilai SBE tertinggi pada tiap penataan tanaman.

Pada Gambar 28, 29, dan 30 yaitu grafik nilai SBE ketiga kategori penyusunan penataan tanaman. Pada grafik dapat dilihat nilai SBE tertinggi dan terendah untuk masing-masing kategori penyusunan tanaman dan juga untuk tiap jalan. Pada pohon massal sejenis nilai SBE terendah terdapat pada lanskap 11 (nilai SBE : 0) terdapat pada Jalan Diponegoro dan tertinggi terdapat pada lanskap 20 (nilai SBE : 100,4) terdapat pada Jalan Sudirman. Lanskap pohon kelompok campuran nilai terendah terdapat pada lanskap 3 (nilai SBE : 0) terdapat pada Jalan Cut Nyak Dien dan tertinggi pada lanskap 8 (nilai SBE :102,5) terdapat pada Jalan Sudirman. Pada massal campuran nilai terendah terdapat pada lanskap 2 (nilai SBE : 0) terdapat pada Jalan Cut Nyak Dien dan tertinggi pada lanskap 14 (nilai SBE : 88,4) tedapat pada Jalan Sudirman. Nilai SBE terendah merupakan lanskap yang dinilai tidak indah dan tidak disukai oleh responden, sedangkan nilai SBE tertinggi merupakan lanskap yang dinilai indah dan disukai oleh responden.

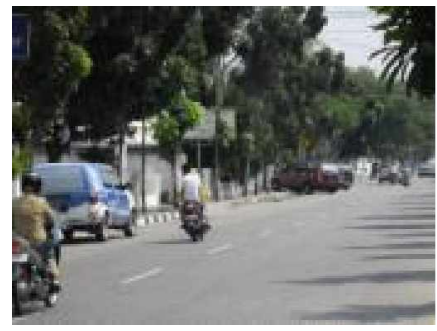

a.

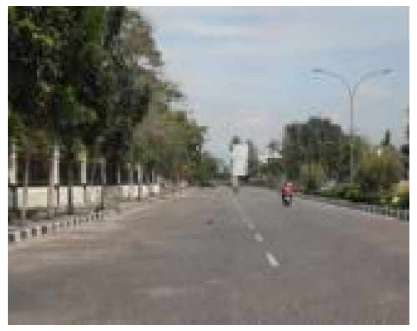

b.

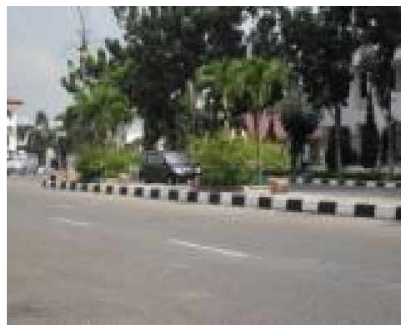

c.

Gambar 26. Lanskap Nilai SBE Terendah Pohon massal Sejenis (a), Pohon Kelompok Campuran (b), Massal Campuran (c) 


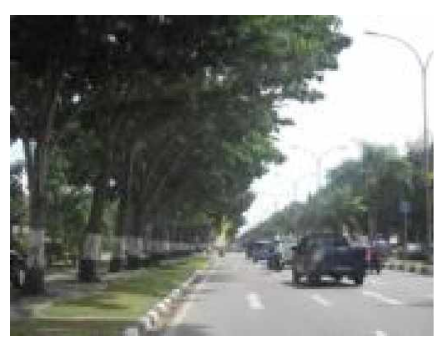

a.

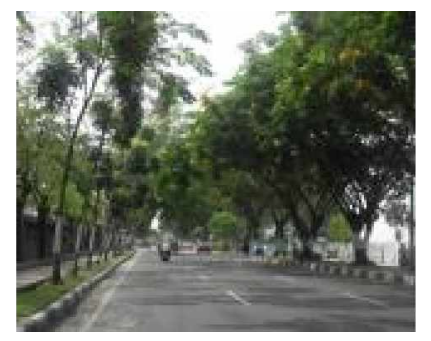

b.

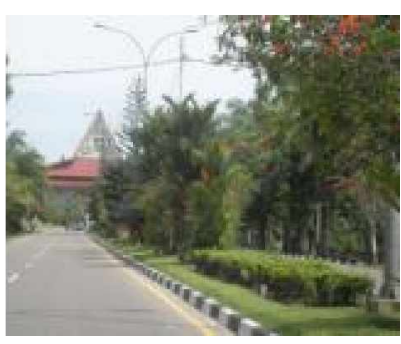

c.

Gambar 27. Lanskap Nilai Tertinggi Pohon Massal Sejenis, Pohon Kelompok Campuran, Massal Campuran

Pada Gambar 28 grafik pohon massal sejenis, pada Jalan Cut Nyak Dien nilai SBE terendah terdapat pada lanskap 3 (nilai SBE : 8,4) dan tertinggi terdapat pada lanskap 4 (nilai SBE : 46,2). Pada Jalan Gajah Mada nilai SBE terendah terdapat pada lanskap 8 (nilai SBE : 12,7) dan nilai SBE tertinggi terdapat pada lanskap 7 (nilai SBE : 53,5). Pada Jalan Diponegoro nilai SBE terendah terdapat pada lanskap 11 (nilai SBE : 0) dan nilai SBE tertinggi terdapat pada lanskap 12 (nilai SBE : 99,9). Pada Jalan Sudirman nilai SBE terendah pada lanskap 20 ( nilai SBE : 100,4) dan nilai tertinggi terdapat pada lanskap 19 (nilai SBE : 23,6).

Pada Gambar 29 grafik pohon kelompok campuran, pada Jalan Cut Nyak Dien nilai SBE terendah terdapat pada lanskap 3 (nilai SBE : 0) dan tertinggi terdapat pada lanskap 1 (nilai SBE : 25,6). Pada Jalan Diponegoro nilai SBE terendah terdapat pada lanskap 4 (nilai SBE : 36,2) dan nilai SBE tertinggi terdapat pada lanskap 5 (nilai SBE : 48,3). Pada Jalan Sudirman nilai SBE terendah terdapat pada lanskap 7 (nilai SBE : 14,5) dan nilai SBE tertinggi terdapat pada lanskap 8 (nilai SBE : 102,5). Pada Jalan Gajah Mada tidak terdapat pohon kelompok campuran.

Pada Gambar 30 grafik massal campuran, pada jalan Cut Nyak Dien nilai SBE terendah terdapat pada lanskap 2 (nilai SBE : 0) dan tertinggi terdapat pada lanskap 3 (nilai SBE : 43,6). Pada Jalan Gajah Mada nilai SBE terendah terdapat pada lanskap 4 (nilai SBE : 31,5) dan nilai SBE tertinggi terdapat pada lanskap 6 (nilai SBE : 77,1). Pada Jalan Diponegoro nilai SBE terendah terdapat pada lanskap 9 (nilai SBE : 38,0) dan nilai SBE tertinggi terdapat pada lanskap 25 (nilai SBE : 60,6). Pada Jalan Sudirman nilai SBE terendah pada lanskap 13 ( nilai SBE : 3,1) dan nilai tertinggi terdapat pada lanskap 14 (nilai SBE : 88,4). 


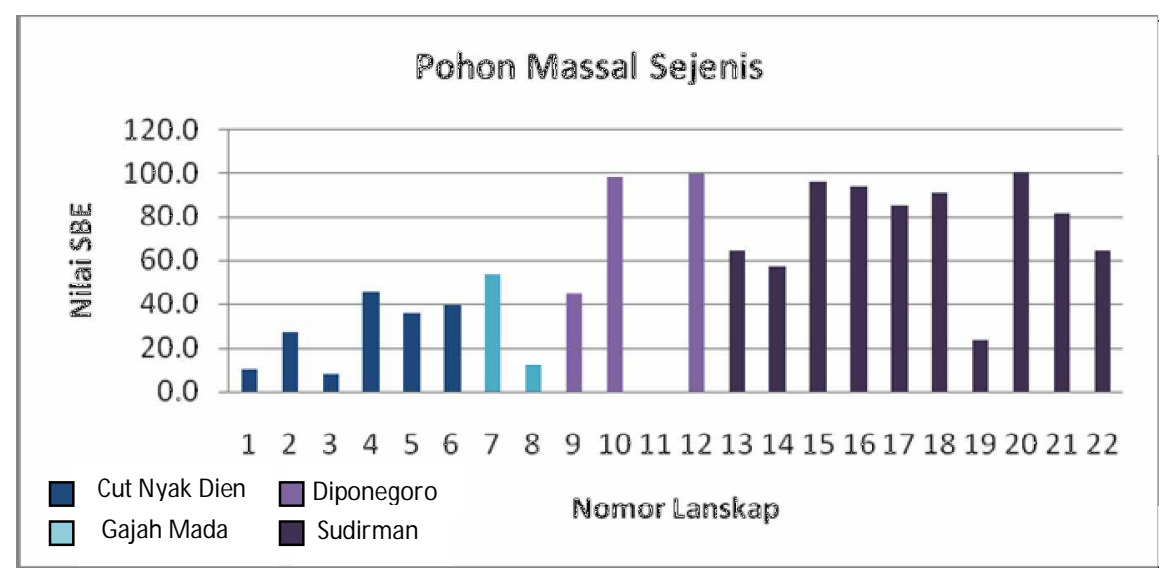

Gambar 28. Grafik nilai SBE Pohon Massal Sejenis

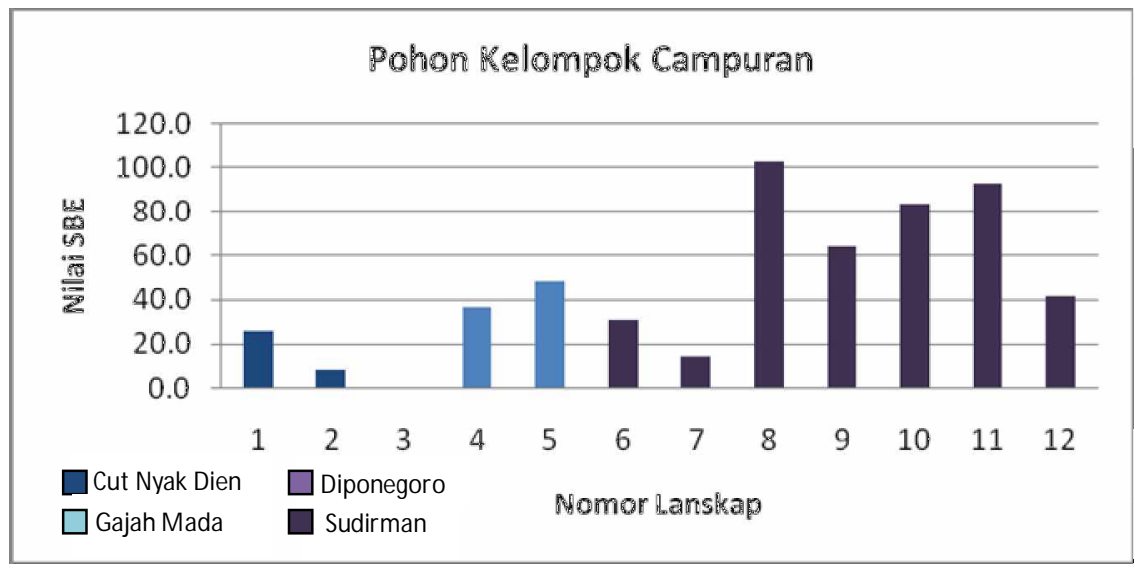

Gambar 29. Grafik Nilai SBE Pohon Kelompok Campuran

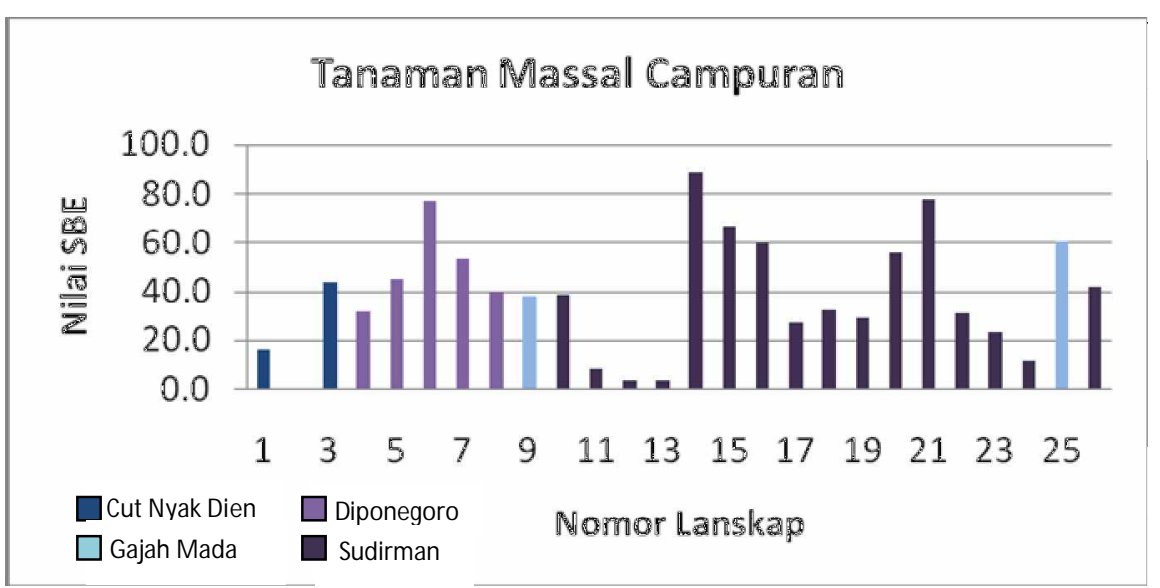

Gambar 30. Grafik Nilai SBE Massal Campuran 


\section{Pengelompokan Keindahan Lanskap Pada Tata Hijau Lanskap Jalan}

Nilai hasil SBE tiap lanskap digunakan untuk melihat kategori keindahan tiap lanskap. Nilai SBE tiap kategori penataan tanaman (Pohon massal sejenis, pohon kelompok campuran, dan tanaman massal campuran) dikelompokkan kedalam 3 keindahan lanskap, yaitu keindahan tinggi, keindahan sedang dan keindahan rendah. Pengelompokan keindahan tiap kategori penataan lanskap dapat dilihat pada Tabel 19. Pengelompokan berdasarkan sebaran normal.

Tabel 19. Pengelompokan Keindahan Lanskap

\begin{tabular}{|c|c|c|c|c|c|c|c|c|c|}
\hline \multirow[t]{3}{*}{ Responden } & \multicolumn{9}{|c|}{ Pengelompokan Keindahan } \\
\hline & \multicolumn{3}{|c|}{ Massal Sejenis } & \multicolumn{3}{|c|}{ Kelompok Campuran } & \multicolumn{3}{|c|}{ Massal Campuran } \\
\hline & Tinggi & Sedang & Rendah & Tinggi & Sedang & Rendah & Tinggi & Sedang & Rendah \\
\hline Mahasiswa & Lanskap & Lanskap & Lanskap & Lanskap & Lanskap & Lanskap & Lanskap & Lanskap & Lanskap \\
\hline $\begin{array}{ll}\text { jumlah } & 50 \\
\text { orang } & \end{array}$ & $\begin{array}{l}10,12, \\
15,16, \\
17,18, \\
20,21\end{array}$ & $\begin{array}{l}4,5,6, \\
7,9,13, \\
14,22\end{array}$ & $\begin{array}{l}1,2,3, \\
8,11,19\end{array}$ & $8,10,11$ & $\begin{array}{l}4,5,9, \\
12\end{array}$ & $\begin{array}{l}1,2,3, \\
6,7\end{array}$ & 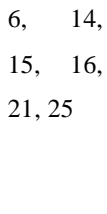 & $\begin{array}{l}3,4,5, \\
7,8,9, \\
10, \quad 18, \\
20, \quad 22, \\
26\end{array}$ & $\begin{array}{ll}1,2, & 11, \\
12, & 13, \\
17, & 23, \\
24 & \end{array}$ \\
\hline
\end{tabular}

Pengelompokan keindahan pada tiap penataan tanaman berdasarkan nilai

SBE yang didapatkan untuk tiap segmen jalan dapat dilihat pada Tabel 20.

Tabel 20. Pengelompokan Keindahan pada Tiap Segmen

\begin{tabular}{|c|c|c|c|c|c|c|c|c|}
\hline \multirow[t]{2}{*}{ Jalan } & \multirow[t]{2}{*}{ Segmen } & \multirow[t]{2}{*}{ Lanskap } & \multicolumn{3}{|c|}{ Penataan Tanaman } & \multicolumn{3}{|c|}{ Keindahan Pemandangan } \\
\hline & & & $\begin{array}{l}\text { Pohon } \\
\text { Massal } \\
\text { Sejenis }\end{array}$ & $\begin{array}{l}\text { Pohon } \\
\text { Kelompok } \\
\text { Campuran }\end{array}$ & $\begin{array}{l}\text { Massal } \\
\text { Campuran }\end{array}$ & Tinggi & Sedang & Rendah \\
\hline \multirow{12}{*}{$\begin{array}{l}\text { Cut Nyak } \\
\text { Dien }\end{array}$} & \multirow[t]{3}{*}{1} & 3 & & $\mathrm{v}$ & & & & $\mathrm{v}$ \\
\hline & & 1 & & & $\mathrm{v}$ & & & $\mathrm{v}$ \\
\hline & & 3 & & & $\mathrm{~V}$ & & $\mathrm{v}$ & \\
\hline & 2 & 1 & & $\mathrm{v}$ & & & & $\mathrm{v}$ \\
\hline & \multirow[t]{3}{*}{3} & 5 & $\mathrm{v}$ & & & & $\mathrm{v}$ & \\
\hline & & 6 & $\mathrm{v}$ & & & & $\mathrm{v}$ & \\
\hline & & 2 & & & $\mathrm{v}$ & & & $\mathrm{v}$ \\
\hline & \multirow[t]{5}{*}{4} & 1 & $\mathrm{v}$ & & & & & $\mathrm{v}$ \\
\hline & & 2 & $\mathrm{v}$ & & & & & $\mathrm{v}$ \\
\hline & & 3 & $\mathrm{v}$ & & & & & $\mathrm{v}$ \\
\hline & & 4 & $\mathrm{v}$ & & & & $\mathrm{v}$ & \\
\hline & & 2 & & $\mathrm{~V}$ & & & & $\mathrm{v}$ \\
\hline \multirow[t]{14}{*}{ Sudirman } & \multirow[t]{4}{*}{1} & 11 & & & $\mathrm{v}$ & & & $\mathrm{v}$ \\
\hline & & 12 & & & $\mathrm{v}$ & & & $\mathrm{v}$ \\
\hline & & 13 & & & $\mathrm{v}$ & & & $\mathrm{v}$ \\
\hline & & 23 & & & $\mathrm{v}$ & & & $\mathrm{v}$ \\
\hline & \multirow[t]{2}{*}{2} & 11 & & $\mathrm{v}$ & & $\mathrm{v}$ & & \\
\hline & & 22 & & & $\mathrm{v}$ & & $\mathrm{v}$ & \\
\hline & \multirow[t]{3}{*}{3} & 22 & $\mathrm{~V}$ & & & & $\mathrm{~V}$ & \\
\hline & & 24 & & & $\mathrm{v}$ & & & $\mathrm{v}$ \\
\hline & & 12 & & $\mathrm{~V}$ & & & $\mathrm{~V}$ & \\
\hline & \multirow[t]{2}{*}{4} & 21 & & & $\mathrm{v}$ & $\mathrm{v}$ & & \\
\hline & & 26 & & & $\mathrm{v}$ & & $\mathrm{v}$ & \\
\hline & 5 & 20 & & & $\mathrm{v}$ & & $\mathrm{v}$ & \\
\hline & \multirow[t]{2}{*}{6} & 14 & $\mathrm{~V}$ & & & & $\mathrm{~V}$ & \\
\hline & & 15 & $\mathrm{~V}$ & & & $\mathrm{~V}$ & & \\
\hline
\end{tabular}


Tabel 20. (Lanjutan)

\begin{tabular}{|c|c|c|c|c|c|c|c|c|}
\hline \multirow[t]{2}{*}{ Jalan } & \multirow[t]{2}{*}{ Segmen } & \multirow[t]{2}{*}{ Lanskap } & \multicolumn{3}{|c|}{ Penataan Tanaman } & \multicolumn{3}{|c|}{ Keindahan Pemandangan } \\
\hline & & & $\begin{array}{l}\text { Pohon } \\
\text { Massal } \\
\text { Sejenis } \\
\end{array}$ & $\begin{array}{l}\text { Pohon } \\
\text { Kelompok } \\
\text { Campuran }\end{array}$ & $\begin{array}{l}\text { Massal } \\
\text { Campuran }\end{array}$ & Tinggi & Sedang & Rendah \\
\hline \multirow[t]{18}{*}{ Sudirman } & \multirow[t]{7}{*}{6} & 16 & $\mathrm{v}$ & & & $\mathrm{v}$ & & \\
\hline & & 21 & $\mathrm{v}$ & & & $\mathrm{v}$ & & \\
\hline & & 6 & & $\mathrm{v}$ & & & & $\mathrm{v}$ \\
\hline & & 7 & & $\mathrm{v}$ & & & & $\mathrm{v}$ \\
\hline & & 8 & & $\mathrm{v}$ & & $\mathrm{v}$ & & \\
\hline & & 9 & & $\mathrm{v}$ & & & $\mathrm{v}$ & \\
\hline & & 10 & & $\mathrm{v}$ & & $\mathrm{v}$ & & \\
\hline & \multirow[t]{5}{*}{7} & 17 & $\mathrm{v}$ & & & $\mathrm{v}$ & & \\
\hline & & 18 & $\mathrm{v}$ & & & $\mathrm{v}$ & & \\
\hline & & 19 & $\mathrm{v}$ & & & & & $\mathrm{v}$ \\
\hline & & 20 & $\mathrm{v}$ & & & $\mathrm{v}$ & & \\
\hline & & 19 & & & $\mathrm{v}$ & & & $\mathrm{v}$ \\
\hline & \multirow[t]{6}{*}{8} & 12 & $\mathrm{v}$ & & & $\mathrm{v}$ & & \\
\hline & & 14 & & & $\mathrm{v}$ & $\mathrm{v}$ & & \\
\hline & & 15 & & & $\mathrm{v}$ & $\mathrm{v}$ & & \\
\hline & & 16 & & & $\mathrm{v}$ & $\mathrm{v}$ & & \\
\hline & & 17 & & & $\mathrm{v}$ & & & $\mathrm{v}$ \\
\hline & & 18 & & & $\mathrm{v}$ & & $\mathrm{v}$ & \\
\hline \multirow{4}{*}{$\begin{array}{l}\text { Gajah } \\
\text { Mada }\end{array}$} & \multirow[t]{4}{*}{1} & 7 & $\mathrm{v}$ & & & & $\mathrm{v}$ & \\
\hline & & 8 & $\mathrm{v}$ & & & & & $\mathrm{v}$ \\
\hline & & 9 & & & $\mathrm{v}$ & & $\mathrm{v}$ & \\
\hline & & 25 & & & $\mathrm{v}$ & $\mathrm{v}$ & & \\
\hline \multirow[t]{10}{*}{ Diponegoro } & \multirow[t]{4}{*}{1} & 9 & $\mathrm{v}$ & & & & & \\
\hline & & 4 & $\mathrm{v}$ & & & & & \\
\hline & & 5 & $\mathrm{v}$ & & & & & \\
\hline & & 6 & $\mathrm{v}$ & & & & & \\
\hline & \multirow[t]{3}{*}{2} & 5 & & $\mathrm{v}$ & & & & \\
\hline & & 7 & & & $\mathrm{v}$ & & & \\
\hline & & 8 & & & $\mathrm{v}$ & & & \\
\hline & \multirow[t]{2}{*}{3} & 10 & $\mathrm{v}$ & & & & & \\
\hline & & 4 & & $\mathrm{v}$ & & & & \\
\hline & 4 & 11 & $\mathrm{v}$ & & & & & \\
\hline
\end{tabular}

\section{Lanskap Pohon Massal Sejenis}

Keindahan Pemandangan Tinggi

Tabel 21. Karakeristik Lanskap Pohon Massal Sejenis dengan Keindahan Pemandangan Tinggi

\begin{tabular}{|c|c|}
\hline Kelompok Lanskap & Karakteristik \\
\hline $\begin{array}{l}\text { Jalan Sudirman (Lanskap 15, 16, 17, 18, } \\
\text { 20, 21) }\end{array}$ & $\begin{array}{l}\text { Pohon Angsana dan mahoni ditanam berbaris, bentuk } \\
\text { tajuk round (Angsna) dan dome (mahoni), jarak tanam } \\
\text { rapat, tajuk bersinggungan, memiliki warna bunga } \\
\text { yang menarik (angsana), batang jelas, ditanam teratur, } \\
\text { rapi. }\end{array}$ \\
\hline Jalan Diponegoro (Lanskap 10, 12) & $\begin{array}{l}\text { Pohon glodogan bulat dan kelapa sawit ditanam } \\
\text { berbaris, jarak tanam rapat, teratur, tajuk saling } \\
\text { bersingunggan, keseragaman tinggi pohon dan bentuk } \\
\text { tajuk, rapi. }\end{array}$ \\
\hline
\end{tabular}

Pada kategori nilai keindahan pemandangan tinggi, lanskap yang termasuk kedalamnya yaitu lanskap 10, 12, 15, 16, 17, 18, 20, dan 21. Pohon massal sejenis 
yang dinilai tinggi oleh responden adalah pohon massal sejenis yang ditanam sejajar berbaris sepanjang tepi jalan, jarak tanam yang rapat, teratur, tajuk saling bersinggungan dan memberikan naungan, rapi, arsitektur tajuk serasi dan memiliki keseragaman jenis. Keseragaman tinggi, bentuk tajuk pohon, dan batang yang berbaris liniear memberikan kesan rapi. Pohon seperti angsana dengan tajuk menarik, warna daun dan bunga menarik memberikan kualitas visual yang indah. Karakteristik lanskap pohon massal sejenis dengan keindahaan tinggi dapat dilihat pada Tabel 21.

Pada gambar 31 dapat terlihat contoh pohon massal sejenis dengan nilai keindahan tinggi. Pada gambar a (Lanskap 10) merupakan susunan pohon glodogan bulat ditanam massal sejenis sepanjang Jalan Diponegoro, memiliki tinggi dan bentuk tajuk yang seragam, ditanam rapat dan tajuk saling bersinggungan. Gambar b (Lanskap 12) merupakan deretan kelapa sawit terdapat pada Jalan Sudirman yang ditanam berbaris memberi kesan rapi dengan susunan pohon yang teratur di sepanjang tepi jalan, berkesan mengarahkan, dan bentuk tajuk sawit yaitu palmae memberikan daya tarik khusus. Gambar c dan d (Lanskap 15 dan lanskap 20) lanskap yang terdapat pada Jalan Sudirman dapat dilihat barisan pohon angsana dan mahoni yang memiliki tajuk saling bersinggungan, memberikan naungan, jarak tanam rapat, ditanam teratur dan rapi sepanjang tepi jalan. Lanskap 20 memiliki nilai SBE tertinggi, pada lanskap ini pohon angsana berbunga berwarna kuning memberi daya tarik khusus pada pohon angsana, warna daun yang kontras dengan warna daun hijau daun angsana menjadi lanskap menarik saat pohon angsana berbunga di sepanjang jalan.

Menurut Reid (1993) kesamaan jenis dan bentuk dalam satu deretan membentuk garis liniear dapat menghasilkan kesan unity sebagai salah satu prinsip desain dalam penataan lanskap untuk mencapai nilai estetika. Penanaman pohon massal sejenis di sepanjang jalan memberikan kesan unity yang kuat dan unity merupakan salah satu prinsip desain yang harus diterapakan dalam desain agar menghasilkan nilai estetika yang baik. Adanya repetisi dengan menanam pohon satu jenis dalam satu kelompok memberikan kesan rapi dan teratur. Menurut Setyanti (2004) Penanaman massal dalam komposisi desain lanskap 
dipakai karena penyusunan penanaman tersebut menimbulkan kesan kesatuan visual, kesan alami dan memberi kondisi optimal pertumbuhannya.

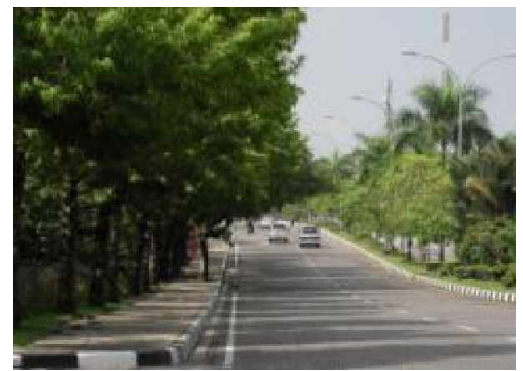

a. Lanskap 10

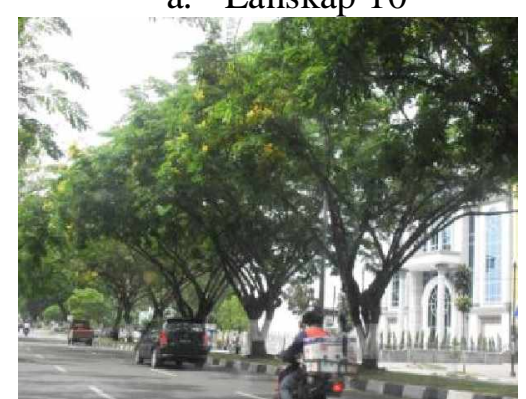

a. Lanskap 15

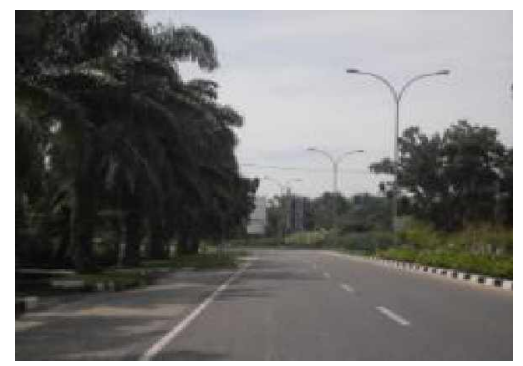

b. Lanskap 12

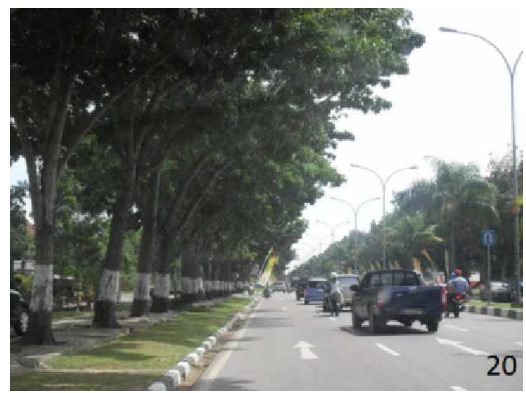

b. Lanskap 20

Gambar 31. Lanskap keindahan pemandangan tinggi pohon massal sejenis pada Jl. Diponegoro (a) dan J1. Sudirman (b, c, dan d)

\section{Keindahan Pemandangan Sedang}

Tabel 22. Karakeristik Lanskap Pohon Massal Sejenis dengan Keindahan Pemandangan Sedang

\begin{tabular}{|l|l|}
\hline \multicolumn{1}{|c|}{ Kelompok Lanskap } & \multicolumn{1}{c|}{ Karakteristik } \\
\hline Jalan Cut Nyak Dien (Lanskap 4) & $\begin{array}{l}\text { Pohon Tanjung ditanam dengan jarak kurang rapat, } \\
\text { bentuk tajuk antar pohon yang tidak seragam }\end{array}$ \\
\hline Jalan Sudirman ( Lanskap 13, 14, 22) & $\begin{array}{l}\text { Pohon angsana pada lanskap 14 memiliki bentuk tajuk } \\
\text { yang tidak sempurna akibat baru dipangkas, pada } \\
\text { lanskap 22 terdapat pagar pembatas median sehingga } \\
\text { terlihat kurang alami, ketidakseragaman bentuk tajuk } \\
\text { pohon bintaro }\end{array}$ \\
\hline Jalan Gajah Mada (Lanskap 7) & $\begin{array}{l}\text { Pohon mahoni ditanam dengan jarak rapat tetapi } \\
\text { bentuk tajuk belum maksimum (pohon baru ditanam), } \\
\text { tinggi dan bentuk tajuk tidak seragam }\end{array}$ \\
\hline Jalan Diponegoro (Lanskap 9) & $\begin{array}{l}\text { Pohon tanjung yang ditanam dengan jarak kurang } \\
\text { rapat, tajuk pohon tidak seragam }\end{array}$ \\
\hline
\end{tabular}

Pada kategori nilai keindahan pemandangan sedang, lanskap yang termasuk kedalamnya yaitu lanskap 4, 5, 6, 7, 9, 13, 14, dan 22. Pada lanskap pohon massal sejenis memiliki nilai keindahan pemandangan sedang yaitu pohon yang ditanam berbaris sepanjang jalan dengan jarak kurang rapat, bentuk tajuk yang belum sempurna, ketidakseragaman bentuk tajuk dan tinggi pohon. 
Karakteristik lanskap pohon massal sejenis dengan keindahaan sedang dapat dilihat pada Tabel 22 .

Pada Gambar 32 dapat terlihat contoh pohon massal sejenis dengan nilai keindahan sedang. Pada Gambar a dan c (Lanskap 4 dan 13) yaitu lanskap yang terdapat pada Jalan Cut Nyak Dien dan Jalan Diponegoro merupakan barisan pohon tanjung ditanam sepanjang jalan dengan tajuk bulat tetapi jarak kurang rapat, tajuk pohon tajung yang bulat bisa menjadi pembatas visual. Pada Gambar b (Lanskap 5) barisan pohon mahoni pada Jalan Cut Nyak Dien belum menunjukkan bentuk tajuk yang belum sempurna, tinggi dan bentuk tajuk antar pohon yang tidak seragam sehingga terlihat kurang estetis. Pada Gambar d (Lanskap 14) terdapat pada Jalan Sudirman deretan pohon angsana dengan tajuk yang kurang sempurna akibat pemangkasan sehingga membuat tajuk tidak rapat dan terlihat tidak rapi. Pemangkasan terhadap pohon perlu untuk memperhatikan bentuk tajuk yang dibentuk agar tetap tercipta visual yang indah.

Pada desain tata hijau jalan diperlukan keseimbangan agar menghasilkan nilai estetika yang baik. Keseimbangan (balance) merupkan prinsip desain lanskap yang paling menuntut kepekaan (Reid, 1993). Keseragaman bentuk tajuk dan tinggi perlu diperhatikan agar tecipta kesimbangan dalam satu kelompok pohon sejenis. Menurut Afrianita (2005) lanskap jalan memiliki nilai sedang yaitu dengan karakteristik proporsi vegetasi dominan tapi cukup seimbang.

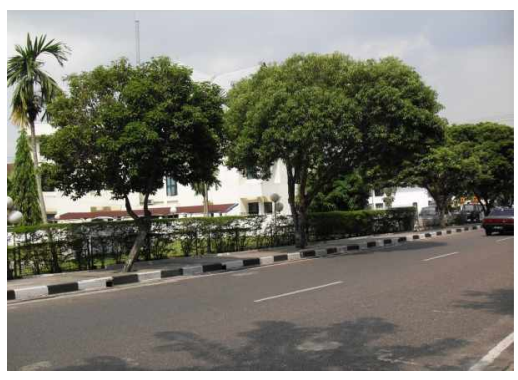

a. Lanskap 4

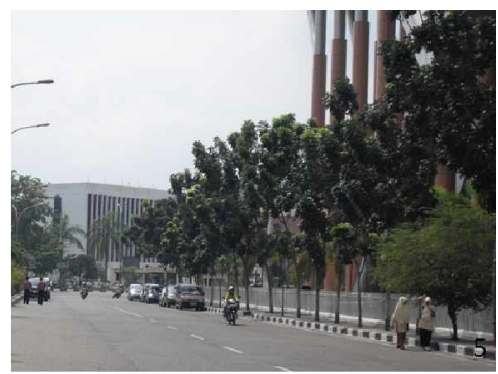

c. Lanskap 5 


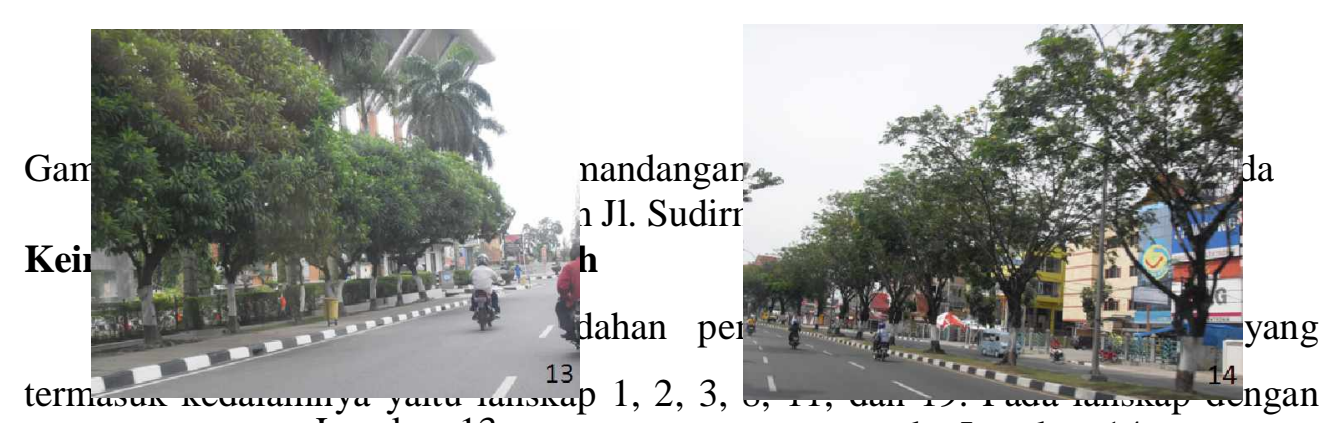

c. Lanskap 13
keindahan pemandangan rendah umumnya pohon ditanam dengan jarak tanam

c. Lanskap 13
keindahan pemandangan rendah umumnya pohon ditanam dengan jarak tanam tidak rapat, bentuk tajuk (arsitektur tajuk) yang tidak sempurna, tinggi pohon dan bentuk tajuk yang tidak seragam. Karakteristik lanskap pohon massal sejenis dengan keindahaan rendah dapat dilihat pada Tabel 23.

Tabel 23. Karakeristik Lanskap Pohon Massal Sejenis dengan Keindahan Pemandangan Rendah

\begin{tabular}{|l|l|}
\hline \multicolumn{1}{|c|}{ Kelompok Lanskap } & \multicolumn{1}{|c|}{ Karakteristik } \\
\hline Jalan Cut Nyak Dien (Lanskap 1,2,3) & $\begin{array}{l}\text { Pohon tanjung dan mahoni ditanam berbaris dengan } \\
\text { jarak tanam tidak rapat, tinggi pohon yang tidak } \\
\text { seragam,bentuk tajuk yang tidak seragam }\end{array}$ \\
\hline Jalan Sudirman ( Lanskap 19) & $\begin{array}{l}\text { Pohon mahoni ditanam kurang rapat, tajuk tidak saling } \\
\text { bersinggungan, }\end{array}$ \\
\hline Jalan Gajah Mada (Lanskap 8 ) & $\begin{array}{l}\text { Barisan pohon mahoni dengan jarak tanam tidak rapat, } \\
\text { ukuran dan bentuk tajuk pohon tidak seragam, } \\
\text { pertumbuhan belum maksimum }\end{array}$ \\
\hline Jalan Diponegoro (Lanskap11 ) & $\begin{array}{l}\text { Pohon mahoni dengan jarak tanam tidak (arsitektur } \\
\text { tajuk) rapat, tinggi pohon dan bentuk tajuk tidak } \\
\text { seragam }\end{array}$ \\
\hline
\end{tabular}

Pada Gambar 33 dapat terlihat contoh pohon massal sejenis dengan nilai keindahan rendah. Pada Gambar a (Lanskap 2) terdapat pada Jalan Cut Nyak Dien, jejeran pohon tanjung dengan bentuk tajuk bulat yang tidak seragam, dan tinggi antar pohon tidak sama. Pada Gambar b (Lanskap 11) terdapat pada Jalan Diponegoro. Lanskap 11 merupakan lanskap dengan nilai SBE terendah, pada lanskap ini terdapat barisan pohon mahoni dengan bentuk tajuk dan tinggi pohon tidak seragam, tajuk pohon belum sempurna. Tepian jalan digunakan sebagai tempat parkir sehingga tampak tidak rapi. 
Keseragaman pohon jenis dalam tinggi, bentuk tajuk, jarak tanam antar pohon perlu diperhatikan agar tercipta suatu kesatuan dan keseimbangan. Menurut Booth (1983) ukuran, bentuk, dan kerapatan tanaman merupakan karakter yang perlu diperhatikan ketika menjaduikan tanaman sebagai elemen struktural. Menurut Reid (1993), untuk menghasilkan taman yang ideal perlu penerapan prinsip desain seperti unity, balance, rhytm, dan emphasis terhadap elemen lanskap sehingga dicapai komposisi yang harmonis.

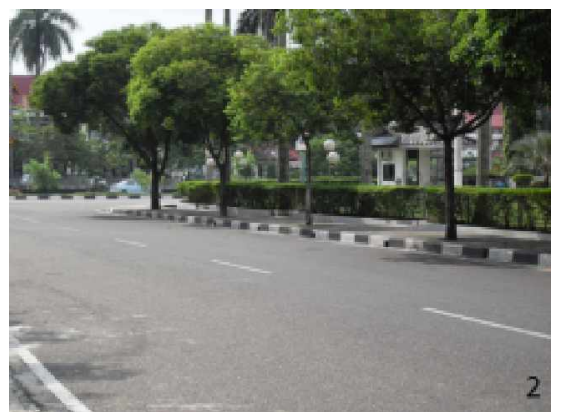

a. Lanskap 2

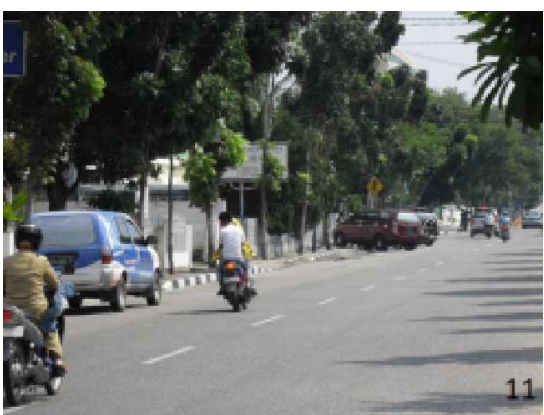

b. Lanskap 11

Gambar 33. Lanskap keindahan pemandangan rendah pohon massal sejenis pada J1. Cut Nyak Dien (a) dan J1. Diponegoro ( b)

\section{Lanskap Pohon Kelompok Campuran}

\section{Keindahan Pemandangan Tinggi}

Pada kategori nilai keindahan pemandangan tinggi, lanskap yang termasuk kedalamnya yaitu lanskap 8,10 , dan 11 . Pada pohon kelompok campuran dengan keindahan pemandangan tinggi, pohon kelompok campuran tersebut memiliki komposisi dan proporsi yang baik sehingga memberikan kesan visual yang indah, ditanam rapat, disusun rapi. Karakteristik lanskap pohon kelompok campuran dengan keindahaan tinggi dapat dilihat pada Tabel 24.

Tabel 24. Karakeristik lanskap Pohon Kelompok Campuran dengan Keindahan Pemandangan Tinggi

\begin{tabular}{|l|l|}
\hline Kelompok Lanskap & \multicolumn{1}{|c|}{ Karakteristik } \\
\hline Jalan Sudirman ( Lanskap 8, 10,11) & Terdapat campuran pohon mahoni, angsana, dan \\
& ketapang dengan tajuk yang saling bersinggungan, \\
& jarak tanam rapat, bentuk tajuk yang serasi, ditanam \\
& dengan susunan rapi, proporsi dan kombinasi yang \\
& seimbang dan harmonis
\end{tabular}

Pada Gambar 34 dapat terlihat contoh pohon kelompok campuran dengan nilai keindahan tinggi. Pada gambar a (Lanskap 8) deretan pohon angasana di median jalan dikomposisikan dengan deretan pohon mahoni di tepian jalan 
memberikan estetika yang indah. Lanskap 8 merupakan lanskap yang memiliki nilai SBE tertinggi. Tajuk kedua pohon yang saling bersinggungan, bentuk tajuk kedua pohon yang serasi, tinggi dan warna pohon yang harmonis. Pada Gambar b (Lanskap 11) terdapat pada Jalan Sudirman, deretan pohon mahoni di median jalan dan pohon ketapang. Penataan yang rapi, jarak tanam rapat, bentuk tajuk yang baik, tinggi mahoni dan ketapang yang hampir sama sehingga terbentuk keseragaman.

Kelompok pohon campuran akan memberikan kualitas visual yang baik apabila memiliki keharmonisan antar pohon, seperti bentuk tajuk, tinggi, warna, dan percabangan yang memiliki komposisi dan proporsi seimbang. Menurut Austin (1982), keragaman jenis pohon dengan bentuk arsitektural yang berbedabeda tetapi dalam komposisi yang harmonis akan menampilkan visualisasi yang memenuhi aspek keindahan. Menurut Rihanah (2004), variasi dibutuhkan untuk menghindari kemonotonan.

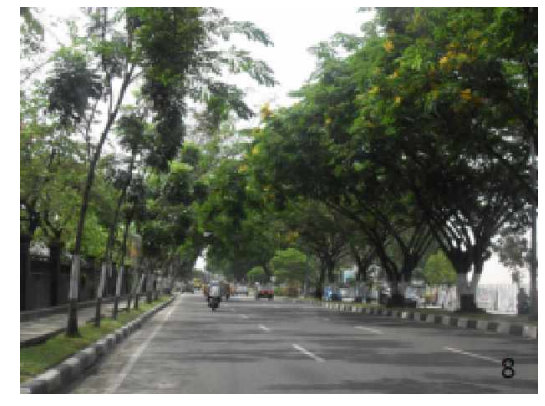

a. Lanskap 8

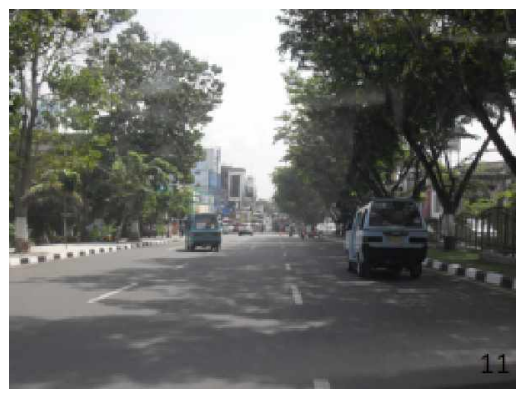

b. Lanskap 11

Gambar 34. Lanskap keindahan pemandangan tinggi pohon kelompok campuran pada Jl.Sudirman (a dan b)

\section{Keindahan Pemandangan Sedang}

Pada kategori nilai keindahan pemandangan sedang, lanskap yang termasuk kedalamnya yaitu lanskap 4, 5, 9 dan 12. Pada keindahan pemandangan sedang, pohon kelompok campuran yang ditanam memiliki banyak variasi pohon dengan komposisi yang kurang tepat, pertumbuhan pohon yang belum maksimal, tata letak yang kurang teratur dan seimbang. Karakteristik lanskap pohon kelompok campuran dengan keindahaan sedang dapat dilihat pada Tabel 24. 
Tabel 25. Karakeristik Lanskap Pohon Kelompok Campuran dengan Keindahan Pemandangan Sedang

\begin{tabular}{|l|l|}
\hline \multicolumn{1}{|c|}{ Kelompok Lanskap } & \multicolumn{1}{c|}{ Karakteristik } \\
\hline Jalan Sudirman ( Lanskap 9, 12) & $\begin{array}{l}\text { Kelompok pohon angsna, mahoni , bintaro dan } \\
\text { kelompok pohon mahoni, angsana dan ketapang, jarak }\end{array}$ \\
& $\begin{array}{l}\text { tanam rapat, susunan tanaman yang kurang teratur, } \\
\text { variasi beragam tetapi kurang menyatu }\end{array}$ \\
\hline Jalan Diponegoro (Lanskap 4,5 ) & $\begin{array}{l}\text { Kelompok pohon bintaro dan palem, jarak tanam } \\
\text { kurang rapat, variasi pohon yang kurang menyatu, } \\
\text { kurang seimbangnya pemilihan campuran pohon }\end{array}$ \\
\hline
\end{tabular}

Pada Gambar 35 dapat terlihat contoh pohon kelompok campuran dengan nilai keindahan sedang. Pada gambar a (Lanskap 5) terdapat pada Jalan Diponegoro, pohon bintaro diselingi dengan palem raja. Tajuk bintaro yang belum maksimal mengurangi keindahan. Pada Gambar b (Lanskap 9) terdapat pada Jalan Sudirman, variasi pohon mahoni, bintaro dan angsana dengan tajuk maksimal tetapi variasi pohon terlalu banyak dan pemilihan pohon yang kurang menyatu.

Variasi pohon pada penanaman lanskap jalan perlu melihat keserasian dan keseimbangan antar pohon. Hal ini ditujukan agar tercipta harmonisasi dan mengurangi kekacauan. Menurut Reid (1993), keseimbangan (balance) merupakan salah satu prinsip desain untuk menunjukkan harmonisasi seluruh komposisi desain terlihat indah.

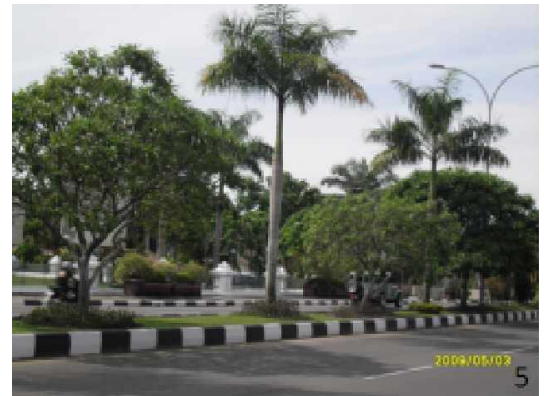

a. Lanskap 5

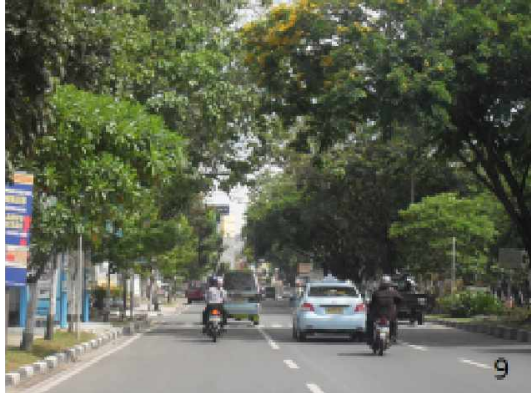

b. Lanskap 9

Gambar 35. Lanskap keindahan pemandangan sedang pohon kelompok campuran pada Jl.Diponegoro (a) dan Jl. Sudirman (b)

\section{Keindahan Pemandangan Rendah}

Pada kategori nilai keindahan pemandangan rendah, lanskap yang termasuk kedalamnya yaitu lanskap 1, 2, 3, 6, dan 7. Pada kelompok campuran pemandangan keindahan sedang dikarenakan jarak tanam yang tidak rapat, keragaman pohon yang tinggi, pertumbuhan tajuk belum maksimal, komposisi 
pohon yang kurang seimbang. Karakteristik lanskap pohon kelompok campuran dengan keindahaan rendah dapat dilihat pada Tabel 26.

Tabel 26. Karakeristik Lanskap Pohon Kelompok Campuran dengan Keindahan Pemandangan Rendah

\begin{tabular}{|l|l|}
\hline \multicolumn{1}{|c|}{ Kelompok Lanskap } & \multicolumn{1}{c|}{ Karakteristik } \\
\hline Jalan Cut Nyak Dien (Lanskap 1, 2,3) & $\begin{array}{l}\text { Campuran pohon mahoni dan palem raja, jarak tanam } \\
\text { kurang rapat tetapi penataan tidak seimbang, tajuk } \\
\text { belum terbentuk maksimal, campuran pohon tanjung } \\
\text { dan mahoni, tinggi dan bentuk tajuk yang tidak } \\
\text { seragam, variasi pohon tidak sesuai }\end{array}$ \\
\hline Jalan Sudirman ( Lanskap 6,7) & $\begin{array}{l}\text { Campuran pohon mahoni dan angsana, bentuk tajuk } \\
\text { yang tidak sempurna/janggal, jarak yang agak } \\
\text { berjauhan, bentuk tajuk belum maksimal }\end{array}$ \\
\hline
\end{tabular}

Pada Gambar 36 dapat terlihat contoh pohon kelompok campuran dengan nilai keindahan rendah. Pada Gambar a (Lanskap 1) terdapat pada Jalan Cut Nyak Dien, penempatan palem raja dan pohon mahoni. Pohon mahoni yang masih berumur muda sehingga pertumbuhan tajuk belum maksimal, tata letak yang saling berjauhan antar pohon, tinggi pohon yang tidak seimbang. Pada Gambar b (lanskap 2) terdapat pada Jalan Cut Nyak Dien, pohon tanjung dan mahoni ditanam berselang-seling. Pengulangan penanaman pohon mahoni dan tanjung yang tidak berpola atau tidak konsisten membuat tidak rapi, tidak seimbang.

Pada penanaman pohon kelompok campuran kesimbangan dan kesatuan perlu untuk diperhatikan. Berbagai macam pohon yang ditanam harus kompak, serasi dan saling mendukung. Menurut Stevens et al (1994), pengelompokkan tanaman harus kompak untuk memberi kesan ketunggalan, irama, dan memenuhi aspek simetri atau asimetri.

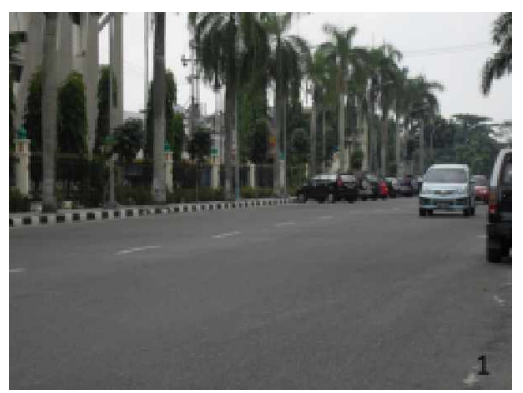

a. Lanskap 1

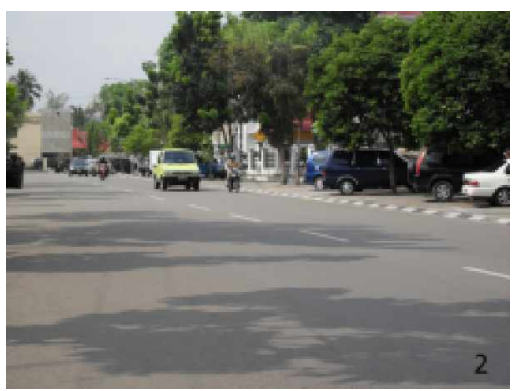

b. Lanskap 2

Gambar 36. Lanskap keindahan pemandangan sedang pohon kelompok campuran pada jalan Cut Nyak Dien (a dan b) 


\section{Lanskap Massal Campuran}

\section{Keindahan Pemandangan Tinggi}

Tabel 27. Karakeristik Lanskap Massal Campuran dengan Keindahan Pemandangan Tinggi

\begin{tabular}{|l|l|}
\hline \multicolumn{1}{|c|}{ Kelompok Lanskap } & \multicolumn{1}{c|}{ Karakteristik } \\
\hline Jalan Sudirman ( Lanskap 14, 15, 16, 21) & $\begin{array}{l}\text { Kombinasi nusa endah dengan bawang-bawangan, } \\
\text { palem merah dengan asoka, bougenvil dengan bakung, }\end{array}$ \\
& $\begin{array}{l}\text { Pemilihan tanaman yang proporsional dan seimbang, } \\
\text { kombinasi, pemilihan warna yang serasi, gradasi tinggi } \\
\text { yang baik }\end{array}$ \\
\hline Jalan Gajah Mada (Lanskap 25 ) & $\begin{array}{l}\text { Kombinasi cemara udang, pola menarik, bentukan } \\
\text { cemara udang yang menarik, pemilihan gradasi warna } \\
\text { yang baik }\end{array}$ \\
\hline Jalan Diponegoro (Lanskap 6 ) & $\begin{array}{l}\text { Kombinasi palem merah dengan rumput, ditanam } \\
\text { dengan pola menarik, perpaduan warna yang menarik, } \\
\text { komposisi yang baik }\end{array}$ \\
\hline
\end{tabular}

Pada kategori nilai keindahan pemandangan tinggi, lanskap yang termasuk kedalamnya yaitu lanskap 6, 14, 15, 16, 21 dan 25. Pada lanskap massal campuran (pohon, perdu dan penutup tanah) dengan keindahan pemandangan tinggi terlihat dengan penanaman kombinasi pohon, perdu dan penutup tanah yang seimbang, kombinasi penanaman pohon besar, pohon kecil, perdu dan penutup tanah yang ditata rapi dengan gradasi tinggi, pemilihan warna dan juga tekstur serasi dan kompak. Proporsi pohon, perdu dan penutup tanah yang baik sehingga memberi kesan kombinasi yang indah dan seimbang. Karakteristik lanskap massal campuran dengan keindahaan tinggi dapat dilihat pada Tabel 27.

Pada Gambar 37 dapat terlihat contoh pohon massal campuran dengan nilai keindahan tinggi. Pada gamabar a (Lanskap 6) terdapat pada Jalan Diponegoro, merupakan kombinasi palem merah, phyllantus niruri dan rumput. Palem merah memiliki bentuk tajuk unik dan batang palem yang berwarna merah memberikan warna yang menarik. Terdapat gradasi tinggi pohon palem merah yang dikombinasi dengan phyllantus niruri. Keindahan pemandangan tinggi juga diciptakan pada gambar b (Lanskap 16), pohon kembang merak dikombinasikan dengan bawang-bawangan. Pada Gambar c (Lanskap 21) deretan cemara lilin dengan bentuk tajuk kolumnar dipadukan dengan phyllantus niruri. Gradasi Warna hijau tua pohon cemara lilin serasi dipadukan dengan warna hijau muda phyllantus niruri. Pada Gambar d (Lanskap 25) median jalan ditanami kombinasi cemara udang, teh-tehan, sutra bombay, agave, kacang-kacangan dengan proporsi 
yang seimbang. Pohon cemara udang memiliki bentuk topiary yang unik dipadukan dengan agave, sutra bombay dan kacang-kacangan berbunga menghasilkan suatu kombinasi warna, tekstur, ukuran dan bentuk yang indah dan serasi. Pada lanskap 14 merupakan lanskap dengan nilai SBE tertinggi, kombinasi pelam merah dengan soka berbunga merah dan bougenvil berbunga oren. Kombinasi tersebut harmoni dalam warna, ukuran, tekstur dan tata letaknya.

Penanaman kombinasi pohon, perdu, dan penutup tanah akan terlihat indah apabila memenuhi unity dan balance. Pemilihan kombinasi tanaman perlu melihat keserasian antar jenis tanaman. Menurut Booth (1983), empat karakteristik visual tanaman yang perlu diperhatikan ukuran, bentuk, warna, tekstur. Menurut Vitasari (2004), gradasi dapat diperoleh dengan perubahan warna, ukuran atau tekstur tanaman teratur. Gradasi tinggi yang baik akan menciptakan suatu skyline yang indah. Pemilihan warna juga perlu diperhatikan agar tidak terlihat kacau. Variasi dibutuhkan agar lanskap tidak terkesan monoton dan dibutuhkan repetisi dan gradasi agar tidak terkesan kacau.

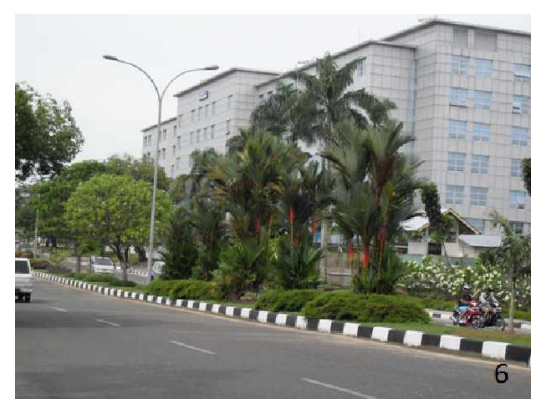

a. Lanskap 6

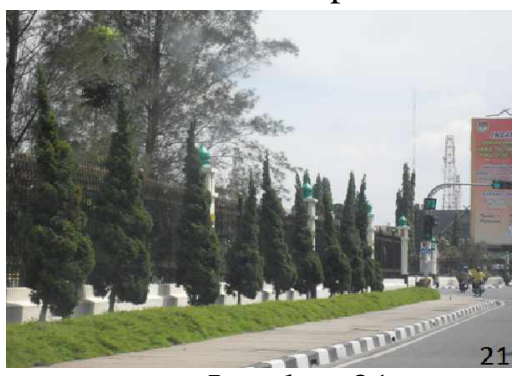

c. Lanskap 21

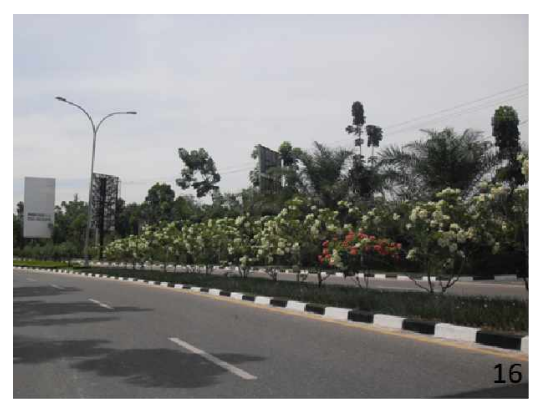

b. Lanskap 16

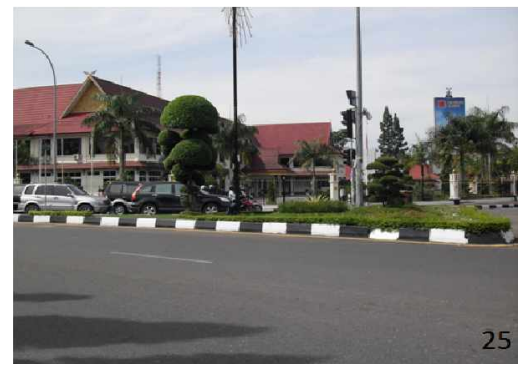

d. Lanskap 25

Gambar 37. Lanskap keindahan pemandangan tinggi massal campuran pada jalan Diponegoro (a), jalan Sudirman (b dan c), dan jalan gajah mada (d) 


\section{Keindahan Pemandangan Sedang}

Tabel 28. Karakeristik Lanskap Massal Campuran dengan Keindahan Pemandangan Sedang

\begin{tabular}{|l|l|}
\hline \multicolumn{1}{|c|}{ Kelompok Lanskap } & \multicolumn{1}{c|}{ Karakteristik } \\
\hline Jalan Cut Nyak Dien (Lanskap 3 ) & $\begin{array}{l}\text { Kombinasi palem hijau dengan bayam-bayaman, teh- } \\
\text { tehan, taiwan putih, penataan rapi, pemilihan perdu } \\
\text { yang begitu bervariasi, pemilihan warna yang kurang } \\
\text { serasi }\end{array}$ \\
\hline $\begin{array}{l}\text { Jalan Sudirman ( Lanskap10, 18, 20, } \\
\text { 22, 26 ) }\end{array}$ & $\begin{array}{l}\text { Kombinasi bintaro dengan bawang,bawangan, ruelia, } \\
\text { asoka, kombinasi kembang merak dengan adam hawa } \\
\text { dan tela-tela, palem dengan ruelia, angsana dengan lili } \\
\text { paris. Variasi perdu yang terlau banyak, peletakkan } \\
\text { tanaman yang kurang teratur }\end{array}$ \\
\hline Jalan Gajah Mada (Lanskap 9) & $\begin{array}{l}\text { Kombinasi cemara udang, bayam-bayaman, pola } \\
\text { menarik, rapi, tata letak sesuai }\end{array}$ \\
\hline Jalan Diponegoro (Lanskap 4, 5, 7 ) & $\begin{array}{l}\text { Beragam kombinasi tanaman seperti palem, bintaro, } \\
\text { ruelia, agave, peletakan yang tumpang tindih, repetasi } \\
\text { dan gradasi yang kurang baik }\end{array}$ \\
\hline
\end{tabular}

Pada kategori nilai keindahan pemandangan sedang, lanskap yang termasuk kedalamnya yaitu lanskap $3,4,5,7,8,9,10,18,20,22$, dan 26 . Pada lanskap massal campuran (pohon, perdu dan penutup tanah) dengan keindahan pemandangan sedang, kombinasi pohon, perdu dan penutup tanah kurang seimbang. Kombinasi massal campuran dengan keragaman terlalu tinggi, penanaman yang tumpang tindih, dan juga pertumbuhan tanaman yang belum maksimal. Karakteristik lanskap massal campuran dengan keindahaan rendah dapat dilihat pada Tabel 28.

Pada gambar 38 dapat terlihat contoh pohon massal campuran dengan nilai keindahan sedang. Pada Gambar a (Lanskap 3) terdapat pada Jalan Cut Nyak Dien deretan palem putri kombinasi dengan bayam-bayaman, teh-tehan, taiwan putih yang dibentuk berpola lingkaran. Pada lanskap ini adanya variasi perdu yang cukup beragam sehingga terlalu ramai dan kurang harmonis. Pada Gambar b (Lanskap 7) terdapat pada Jalan Diponegoro, kombinasi palem, bintaro agave, ruelia, phyllantus niruri. Berbagai macam jenis perdu menjadikan lanskap kacau dan tidak unity, ada perdu yang berbunga (seperti ruelia) dan tidak berbunga (seperti agave, phyllantus niruri), tidak tercipta harmonisasi antara perdu dan pohon. Pada Gambar c dan d (Lanskap 18 dan 20), lanskap terdapat pada Jalan Sudirman. Lanskap 18 kombinasi kembang merak, adam hawa dan tela-tela memberikan visual yang indah. Kembang merak berbunga oranye dipadukan dengan adam hawa berwarna ungu kemerahan dan tela-tela berwarna hijau 
kekuningan. Tata letak tanaman yang berpola membutuhkan pemeliharaan yang baik untuk mempertahankan bentukannya. Lanskap 20 merupakan kombinasi bintaro dengan bawang-bawangan, asoka, bakung, ruelia. Pemilihan perdu sudah baik, pola penanaman juga teratur, tetapi variasi perdu terlalu banyak dan repetisi tidak diperhitungkan dengan baik sehingga penanaman perdu terkesan kacau.

Pada suatu lanskap tanaman campuran (pohon, perdu, penutup tanah) diperlukan suatu harmonisasi agar tercipta lanskap yang seimbang, unity, dan indah. Harmonisasi dapat terbentuk dengan keseimbangan baik proporsi dan komposisi tanaman.

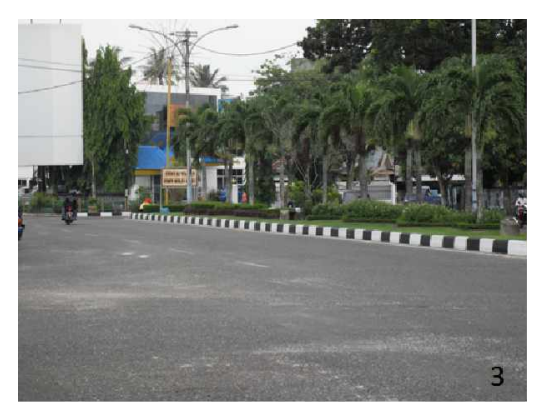

a. Lanskap 3

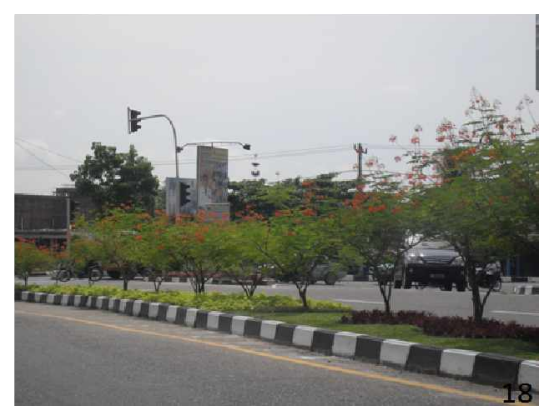

Lanskap 18

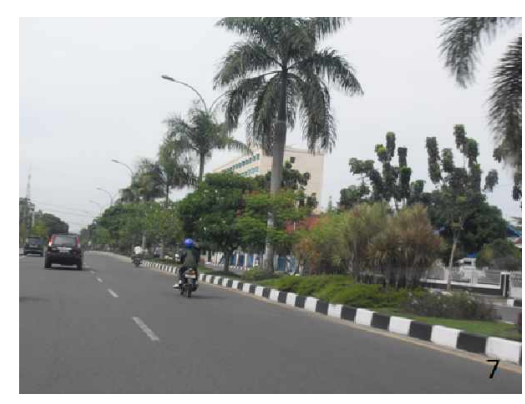

b. Lanskap 7

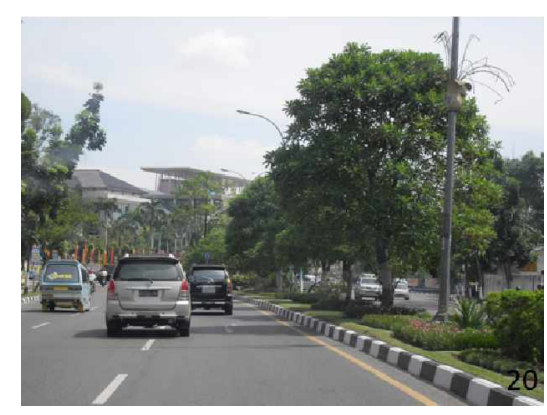

Lanskap 20

Gambar 38. Lanskap keindahan pemandangan sedang massal campuran pada jalan Cut Nyak Dien (a), jalan Diponegoro (b), dan jalan Sudirman (c dan d).

\section{Keindahan Pemandangan Rendah}

Pada kategori nilai keindahan pemandangan rendah, lanskap yang termasuk kedalamnya yaitu lanskap 1, 2, 11, 12, 13, 17, 19, 23, dan 24. Pada lanskap massal campuran (pohon, perdu dan penutup tanah) dengan keindahan pemandangan rendah banyak disebabkan oleh ketidakseimbanagan, terlalu banyak variasi, tidak terawat, tanaman saling tumpang tindih. Karakteristik lanskap massal campuran dengan keindahaan rendah dapat dilihat pada Tabel 28. 
Tabel 29. Karakeristik Lanskap Massal Campuran dengan Keindahan Pemandangan Rendah

\begin{tabular}{|l|l|}
\hline \multicolumn{1}{|c|}{ Kelompok Lanskap } & \multicolumn{1}{c|}{ Karakteristik } \\
\hline Jalan Cut Nyak Dien (Lanskap 1, 2) & $\begin{array}{l}\text { Kombinasi palem putri, kembang merak, bakung, } \\
\text { peletakan tanaman yang tumpah tindih, jarak antar } \\
\text { kelompok tanaman tidak rapat, variasi tanaman terlalu } \\
\text { banyak (agave, palem putri, teh-tehan, ruelia), adanya } \\
\text { perkerasan (paving) pada median jalan }\end{array}$ \\
\hline $\begin{array}{l}\text { Jalan Sudirman ( Lanskap 11, 12,13,17, } \\
\text { 23, 24) }\end{array}$ & $\begin{array}{l}\text { Kombinasi angsana, bakung, mahoni, Gradasi tinggi } \\
\text { yang tidak seimbang, tidak proporsional dalam ukuran, }\end{array}$ \\
\hline
\end{tabular}

Pada Gambar 39 dapat terlihat contoh pohon massal campuran dengan nilai keindahan rendah. Pada Gambar a (lanskap 2 ) terdapat pada Jalan Cut Nyak Dien, pada lanskap ini perkerasan lebih dominan sehingga lanskap kurang terkesan alami, pohon palem dikombinasikan dengan kembang merak dan bakung. Massal campuran ini diletakkan pada planting box dan penanaman tanaman pada planting box tumpang tindih akibat area tanam sempit sehingga tanaman terlihat saling berhimpitan dan kurang rapi. Pada Gambar b yang berada pada Jalan Sudirman, kombinasi nusa indah dengan tela-tela sudah memiliki komposisi dan proporsi yang baik, tetapi adanya kekosongan tanaman (penyulaman tidak dilakukan), harmonisasi warna sudah terbentuk antara nusa indah berbunga putih kekuningan dengan tela-tela berwarna hijua kekuningan. Pada Gambar c (Lanskap 19) terdapat pada Jalan Sudirman, kombinasi agave, ruelia, bougenvil, bawangbawangan, terlalu banyak variasi tanaman dan ditanam dengan pola yang kurang jelas sehingga terlihat tumpang tindih. Pada Gambar d (Lanskap 23) terdapat pada Jalan Sudirman, deretan pohon angsana dikombinasikan dengan bakung dan phyllantus niruri yang ditanam di dalam planting box. Planting box lebih banyak kosong, banyak area kosong pada tanah (penyulaman bakung rendah), dan pertumbuhan yang belum optimal pohon mahoni sehingga lanskap menjadi kurang indah.

Pada penanaman dengan kombinasi pohon, perdu dan penutup tanah diperlukan kekompakan dalam ukuran, warna, penataan. Pola penanaman juga harus teratur dan jangan terlalu banyak variasi tanaman yang dapat menyebabkan kekacauan. Kekacauan dapat dikurangi dengan repetisi dan gradasi. Repetisi dilakukan dengan memunculkan secara berulang suatu kelompok kombinasi tanaman. Menurut Vitasari (2004), gradasi dapat diperoleh dengan menyusun atau mengelompokkan tanaman berdasarkan perubahan warna, ukuran atau tekstur 
tanaman secara teratur dan untuk mengimbangi kecepatan kenderaan penyajian tanaman secara massal dapat dilakukan dengan perubahan jenis minimal 240-320 m sehingga kesan warna, bentuk, maupun tekstur tanaman dapat ditangkap mata penggemudi.

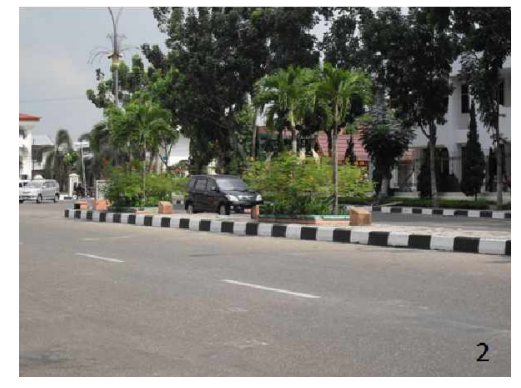

a.Lanskap 2

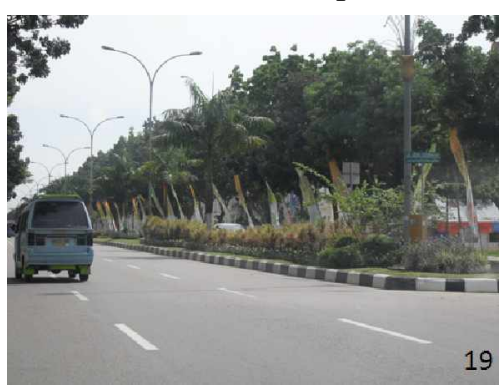

c. Lanskap 19

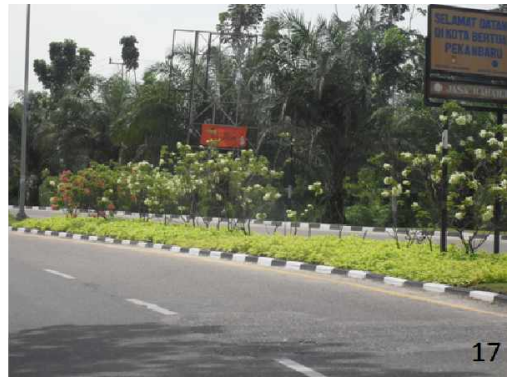

b. Lanskap 17

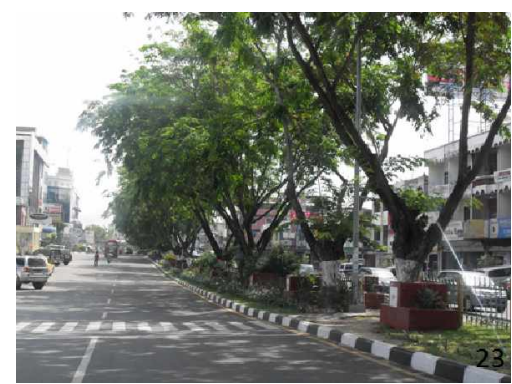

d. Lanskap 23

Gambar 39. Lanskap keindahan pemandangan rendah massal campuran pada Jalan Cut Nyak Dien (a) dan Jalan Sudirman (b,c, dan d) 


\section{Penilaian Aspek Pengelolaan Tanaman Lanskap Jalan}

Penilaian terhadap pengelolaan melihat pada dua aspek yaitu dari segi desain dan teknis. Setelah dilakukan penilaian maka nilai akhir dimasukkan kedalam 4 kategori yaitu, 1. Kategori sangat baik, 2. Kategori baik, 3. Kategori sedang, dan 4. Kategori buruk. Hasil penilaian tiap fungsi dideskripsikan per segmen pada jalan lokasi penelitian.

\section{Segi Desain}

Kriteria penilaian pengelolaan pada segi desain yaitu ; penggunaan pola tanaman yang sederhana/tidak rumit (pemeliharaan mudah), penggunaan tanaman yang tidak memerlukan perawatan intensif, penggunaan tanaman yang mudah didapatkan (penyulaman mudah). Penilaian untuk pengelolaan segi desain dapat dilihat pada Tabel 30 .

Tabel 30. Penilaian Pengelolaan Segi Desain

\begin{tabular}{|c|c|c|c|c|c|c|}
\hline \multirow[t]{2}{*}{ Nama Jalan } & \multirow[t]{2}{*}{ Segmen } & \multicolumn{3}{|c|}{ Kriteria Penilaian } & \multirow[t]{2}{*}{ Skor $(\%)$} & \multirow[t]{2}{*}{ Kategori } \\
\hline & & 1 & 2 & 3 & & \\
\hline \multirow{4}{*}{$\begin{array}{l}\text { Cut } \quad \text { Nyak } \\
\text { Dien }\end{array}$} & 1 & 3 & 3 & 2 & 58,3 & Baik \\
\hline & 2 & 3 & 3 & 2 & 66,7 & Baik \\
\hline & 3 & 2 & 2 & 3 & 58,3 & Sedang \\
\hline & 4 & 3 & 3 & 3 & 75 & Baik \\
\hline \multicolumn{5}{|l|}{ Total Rata-rata } & 77,1 & Baik \\
\hline \multirow[t]{8}{*}{ Sudirman } & 1 & 2 & 2 & 3 & 58,3 & Sedang \\
\hline & 2 & 3 & 3 & 3 & 75 & Baik \\
\hline & 3 & 3 & 3 & 3 & 75 & Baik \\
\hline & 4 & 1 & 1 & 3 & 41,7 & Sedang \\
\hline & 5 & 2 & 2 & 3 & 58,3 & Sedang \\
\hline & 6 & 4 & 4 & 3 & 91,7 & Sangat Baik \\
\hline & 7 & 2 & 3 & 3 & 66,7 & Baik \\
\hline & 8 & 2 & 3 & 3 & 66,7 & Baik \\
\hline \multicolumn{5}{|l|}{ Total Rata-rata } & 66,7 & Baik \\
\hline Gajah Mada & 1 & 2 & 2 & 3 & 58,3 & Sedang \\
\hline \multicolumn{5}{|l|}{ Total Rata-rata } & 58,3 & Sedang \\
\hline \multirow[t]{4}{*}{ Diponegoro } & 1 & 2 & 2 & 3 & 58,3 & Sedang \\
\hline & 2 & 2 & 2 & 3 & 58,3 & Sedang \\
\hline & 3 & 2 & 2 & 3 & 58,3 & Sedang \\
\hline & 4 & 2 & 2 & 3 & 58,3 & Sedang \\
\hline \multicolumn{5}{|l|}{ Total Rata-rata } & 58,3 & Sedang \\
\hline Keterangan : & \multicolumn{6}{|c|}{$\begin{array}{l}\text { Nilai } 1 \text { : Buruk, bila [ } 40 \% \text { kriteria terpenuhi } \\
\text { Nilai } 2 \text { : Sedang, bila 41-60\% kriteria terpenuhi } \\
\text { Nilai } 3 \text { : Baik, bila } 61-80 \% \text { kriteria terpenuhi } \\
\text { Nilai } 4 \text { : Sangat baik, bila / } 81 \% \text { kriteria terpenuhi }\end{array}$} \\
\hline
\end{tabular}




\section{Jalan Cut Nyak Dien}

Segmen 1, penilaian pada segmen ini menunjukkan bahwa 58,3\% dari 3 kriteria terpenuhi dan termasuk kedalam kategori baik. Pada ruas jalan ini terdapat median jalan yang ditanami pohon palem dikombinasikan dengan perdu dan penutup tanah serta rumput. Kombinasi tanaman ini dibentuk dengan pola lingkaran, persegi membentuk taman pada median jalan. Tanaman yang digunakan adalah tanaman lanskap yang mudah ditemukan. Pemeliharaannya memerlukan pemotongan dan pembentukan perdu agar sesuai desain awal. Pada kedua sisi jalan pohon yang digunakan adalah pohon mahoni yan ditanam sejajar membentuk satu garis sepanjang jalan. Pada pengelolaannya pohon tepi jalan ini tidak memerlukan pemeliharaan yang intensif. Pada Gambar 40 dapat dilihat kombinasi palem dan perdu pada median jalan. Perdu yang dibentuk dengan polapola lingkaran membutuhkan perawatan yang intensif seperti pemangkasan yang berkala.

Segmen 2, penilaian pada segmen ini menunjukkan bahwa 66,7\% dari 3 kriteria terpenuhi dan termasuk kedalam kategori baik. Pada segmen ini tidak memiliki median jalan. Kedua sisi jalan ditanami pohon palem diselingi dengan mahoni. pada segmen jalan ini tidak terdapat pola yang rumit dan tidak memerlukan perawatan yang intensif. Desain yang sederhana berupa penanaman pohon dengan pola segaris sepanjang jalan memudahkan pemeliharaan.

Segmen 3, penilaian pada segmen ini menunjukkan bahwa 58,3\% dari 3 kriteria terpenuhi dan termasuk kedalam kategori baik. Pada segmen ini terdapat median. Pada median ditanami pohon palem, kembang merak, cassia glauca dan perdu. Tanaman ini ditanam dalam space berbentuk persegi dan antar persegi dengan persegi lainnya dihubungkan dengan paving block. Adanya perkerasan memudahkan pemeliharaan sebab pola menjadi lebih sederhana tidak terdapat perdu yang harus dipangkas intensif. Pada kedua sisi jalan terdapat pohon mahoni yang ditanam sejajar sepanjang jalan. Pada satu sisi jalan yang lain terdapat cemara lilin dan penutup tanah tetapi kedua kombinasi tanaman ini ditanam dengan pola sederhana ditanam segaris sepanjang trotoar. 
Segmen 4, penilaian pada segmen ini menunjukkan bahwa $75 \%$ dari 3 kriteria terpenuhi dan termasuk kedalam kategori baik. Segmen ini ditanami pohon beraneka ragam yang ditanam segaris sepanjang kedua sisi jalan. Pohon-pohon di sisi jalan anatraa lain pohon tanjung, mahoni, matoa. Pohon-pohon in memberi kesan alami pada jalan.

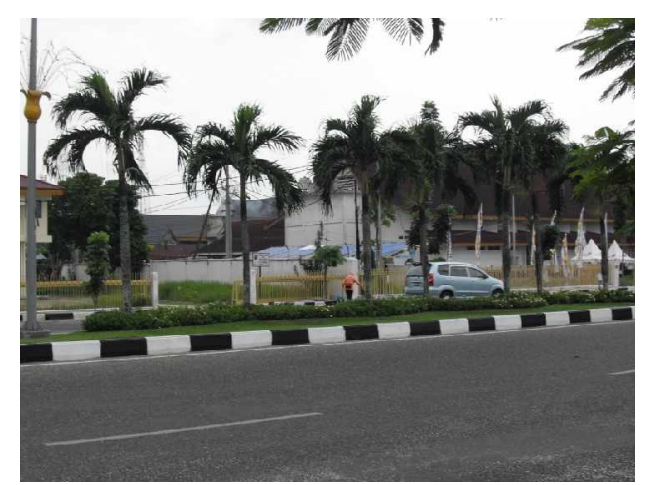

Gambar 40. Desain Penanaman pada Jalan Cut Nyak Dien, pedu yang dibentuk Membutuhkan Pemeliharaan Intensif

\section{Jalan Sudirman}

Segmen 1, penilaian pada segmen ini menunjukkan bahwa 58,3\% dari 3 kriteria terpenuhi dan termasuk kedalam kategori sedang. Median jalan yang ditanami pohon angsana dengan pola sejajar sepanjang median jalan. Diantara pohon diletakkan planting box yang ditanami perdu. Perdu didalam planting box membutuhkan perawatan untuk tetap menjaga tinggi perdu dan nilai estetika sesuai desain awal. Peletakkan planting box segaris lurus sepanjang median jalan memberikan kemudahan dalam perawatan.

Segmen 2, penilaian pada segmen ini menunjukkan bahwa $75 \%$ dari 3 kriteria terpenuhi dan termasuk kedalam kategori baik. Pada segmen ini median jalan hanya ditanami pohon angsana dan penutup tanah/rumput. Pola penanaman pohon angsana segaris lurus sepanjang median jalan sehingga pemeliharaan mudah. Penutup tanah berupa rumput juga memudahkan penyulaman.

Segmen 3, penilaian pada segmen ini menunjukkan bahwa $75 \%$ dari 3 kriteria terpenuhi dan termasuk kedalam kategori baik. Pada segmen ini median jalan masih ditanami dengan angsana tetapi dikombinasikan dengan perdu dan penutup tanah rumput. Pola penanaman pohon angsana masih mengikuti garis sepanjang median dan penanaman perdu pun tidak begitu menyulitkan karena polanya juga 
membentuk garis sepanjang median jalan. Perdu yang dipilih adalah perdu yang mudah dalam penyulaman. Pada kedua sisi jalan ditanami pohon mahoni secara alami dibiarkan tumbuh dengan pola segaris sepanjang kedua sisi jalan.

Segmen 4, penilaian pada segmen ini menunjukkan bahwa 41,7\% dari 3 kriteria terpenuhi dan termasuk kedalam kategori sedang. Pada segmen ini median jalan ditanami pohon dan kombinasi perdu dan penutup tanah yang memiliki pola membentuk taman pada median taman. Pola lingkaran dan persegi, kombinasi cemara udang yang memiliki bentuk topiary dengan perdu seperti soka dibentuk pola melingkar dan membulat lalu terdapat juga mawar dan perdu lainnya. Pola seperti ini membutuhkan perawatan secara intensif karena polanya yang tidak biasa. Pada kedua sisi jalan ditanami pohon mahoni.

Segmen 5, penilaian pada segmen ini menunjukkan bahwa 58,3\% dari 3 kriteria terpenuhi dan termasuk kedalam kategori baik. Pada kedua sisi jalan ditanami pohon mahoni dengan pola sejajar. Pada median jalan ditanami pohon bintaro dikombinasikan dengan perdu. Pola yang dibuat tidak teralu rumit berbentuk persegi. Tanaman mudah dilakukan penyulaman.

Segmen 6, penilaian pada segmen ini menunjukkan bahwa 91,7\% dari 3 kriteria terpenuhi dan termasuk kedalam kategori sangat baik. Pada segmen ini adalah segmen yang memiliki pola sederhana dan tidak memerlukan perawatan yang intensif. Pada median jalan ditanami pohon angsana dan pada kedua sisi jalan ditanami pohon mahoni. Pola penanaman adelah linier atau garis lurus.

Segmen 7, penilaian pada segmen ini menunjukkan bahwa 66,7\% dari 3 kriteria terpenuhi dan termasuk kedalam kategori baik. Pada segmen kedua sisi jalan masih ditanami pohon mahoni yang ditanam sepanjang tepi jalan. Median jalan ditanami palem dan juga dikombinasikan dengan perdu dan penutup tanah. Pada median jalan dibutuhkan sedikit tenaga dalam pemeliharaan teutama pada pemeliharaan perdu.

Segmen 8, penilaian pada segmen ini menunjukkan bahwa $66,6 \%$ dari 3 kriteria terpenuhi dan termasuk kedalam kategori baik. pada median jalan ditanami kembang merak, cassaia glauca, palem merah dan perdu. Kedua sisi jalan ditanami pohon sawit dan beberapa pohon. Kedua sisi jalan dibiarkan dalam keadaan alami. Median jalan tidak memiliki pola yang begitu rumit. Pohon palem, 
nusa indah dan perdu seperti bougenvil ditanam dengan pola linear sepanjang median jalan.

\section{Jalan Gajah Mada}

Segmen 1, penilaian pada segmen ini menunjukkan bahwa 58,3\% dari 3 kriteria terpenuhi dan termasuk kedalam kategori sedang. Segmen ini sebenarnya tidak membutuhkan pemeliharaan intensif sebab pola penanaman pada kedua sisi sederhana dan penyulaman mudah dilakukan. Pada kedua sisi jalan ditanami pohon mahoni. Hanya saja median jalan yang ditanami cemara udang dan perdu yang dibuat berpola dan membutuhkan perawatan intensif seperti pemangkasan untuk mempertahankan desain awal. Pada Gambar 41 dapau dilihat desain penanaman pada median Jalan Gajah Mada yng membutuhkan perawatan intensif.

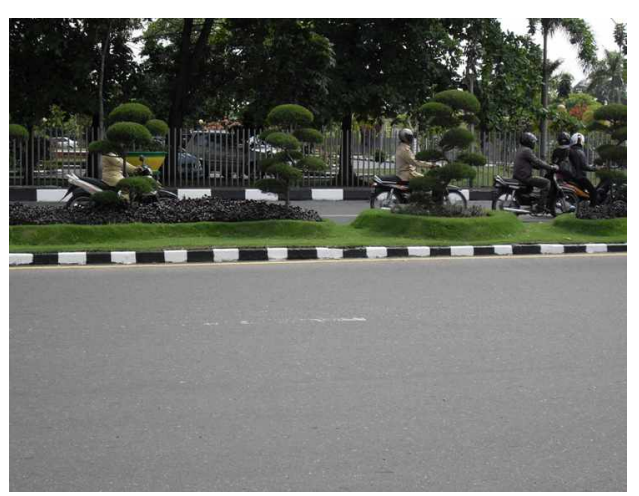

Gambar 41. Desain Penanaman pada Jalan Gajah Mada yang Membutuhkan Pemeliharaan Intensif

\section{Jalan Diponegoro}

Segmen 1, penilaian pada segmen ini menunjukkan bahwa 58,3\% dari 3 kriteria terpenuhi dan termasuk kedalam kategori sedang. Pada kedua sisi jalan ditanam pohon tanjung dengan pola garis lurus sepanjang jalan. Median jalan ditanami kombinasi pohon palem, bintaro, perdu dan penutup tanah dengan pola persegi dan lingkaran. Median jalan membutuhkan pemeliharaan yang lebih intensif dibanding tepi jalan yang ditanam tanaman yang berkesan alami.

Segmen 2, penilaian pada segmen ini menunjukkan bahwa 58,3\% dari 3 kriteria terpenuhi dan termasuk kedalam kategori sedang. Pada segmen ini terdapat planting box pada satu sisi yang ditanami bougenvil. Planting box ini diletakkan sepanjang jalan. Pada satu sisi jalan terdapat pohon mahoni yang ditanam 
sepanjang jalan. Kedua sisi jalan tidak membutuhkan perawatan yang intensif. Hanya saja bougenvil yang membutuhkan pemangkasan agar tinggi tanaman sesuai dengan fungsi awal. Median jalan yang ditanami pohon dan perdu membentuk pola-pola lingkaran, persegi. Pohon bintaro dan palem dikombinasikan dengan perdu. Pada median ini penanaman dengan pola tertentu diulang-ulang sepanjang median jalan. Hal ini membutuhkan perawatan yang intensif seperti pemangkasan, dan penyulaman tanaman.

Segmen 3, penilaian pada segmen ini menunjukkan bahwa 58,3\% dari 3 kriteria terpenuhi dan termasuk kedalam kategori sedang. Pada segmen ini kedua sisi jalan masih ditanami pohon mahoni dan glodogan bulat yang dibiarkan memberikan kesan lanskap alami. Pada median jalan masih ditanami pohon palem, bintaro dan kombinasi perdu dan penutup tanah yang dibentuk menjadi pola tertentu sehingga membutuhkan perawatan yang lebih untuk menjaga desain awal.

Segmen 4, penilaian pada segmen ini menunjukkan bahwa 58,3\% dari 3 kriteria terpenuhi dan termasuk kedalam kategori sedang. Pada segmen ini kedua sisi jalan ditanami pohon mahoni, glodogan tiang dan tanjung. Pohon-pohon ini ditanam sepanjng tepi jalan. Perawatannya mudah sebab pola tanam yang sederhana dan penyulaman yang mudah. Sedangkan untuk median jalan yang menggunakan kombinasi pohon perdu dan penutup tanah membutuhkan perawatan yang lebih intensif sebab pola yang tidak sederhana.

Menurut Sulistyantara (2006), upaya untuk mempermudah ataupun mendukung pemeliharaan ideal salah satunya adalah merencanakan taman dengan pola-pola sederhana. Untuk meminimalisasikan pemeliharaan, elemen tanaman yang membutuhkan banyak pemeliharaan seperti tanaman semusim, topiary,dan tanaman yang memerlukan perawatan khusus perlu dikurangi atau dihindari (Vitasari, 2004).

\section{Segi Teknik}

Kriteria penilaian pengelolaan dari segi teknis antara lain; penyiraman sesuai kebutuhan tanaman, penyiangan dilakukan secara teratur, pemangkasan dilakukan secara teratur sesuai tujuan dan kebutuhan, pemupukan dilakukan 
secara teratur, penyulaman dilakukan sesuai kebutuhan, pengendalian HPT dilakukan secara teratur. Penilaian pengelolaan segi teknik dilihat pada Tabel 31.

Tabel 31. Penilaian Pengelolaan Segi Teknik

\begin{tabular}{|c|c|c|c|c|c|c|c|c|c|}
\hline \multirow[t]{2}{*}{ Nama Jalan } & \multirow[t]{2}{*}{ Segmen } & \multicolumn{6}{|c|}{ Kriteria Penilaian } & \multirow{2}{*}{$\begin{array}{c}\text { Skor } \\
(\%)\end{array}$} & \multirow[t]{2}{*}{ Kategor } \\
\hline & & 1 & 2 & 3 & 4 & 5 & 6 & & \\
\hline \multirow{4}{*}{$\begin{array}{l}\text { Cut } \\
\text { Dien }\end{array}$} & 1 & 3 & 3 & 4 & 3 & 3 & 3 & 79,2 & Baik \\
\hline & 2 & 3 & 3 & 4 & 3 & 2 & 3 & 75 & Baik \\
\hline & 3 & 3 & 3 & 4 & 3 & 3 & 3 & 79,2 & Baik \\
\hline & 4 & 3 & 3 & 4 & 3 & 2 & 3 & 75 & Baik \\
\hline \multicolumn{8}{|l|}{ Total Rata-rata } & 77,1 & Baik \\
\hline \multirow[t]{8}{*}{ Sudirman } & 1 & 3 & 2 & 3 & 3 & 2 & 2 & 62,5 & Baik \\
\hline & 2 & 3 & 3 & 3 & 3 & 2 & 2 & 66,7 & Baik \\
\hline & 3 & 3 & 2 & 3 & 3 & 2 & 2 & 62,5 & Baik \\
\hline & 4 & 3 & 3 & 3 & 3 & 3 & 2 & 70,8 & Biak \\
\hline & 5 & 3 & 3 & 3 & 3 & 3 & 2 & 70,8 & Baik \\
\hline & 6 & 3 & 3 & 3 & 2 & 2 & 2 & 62,5 & Baik \\
\hline & 7 & 3 & 3 & 3 & 3 & 2 & 2 & 66,7 & Baik \\
\hline & 8 & 3 & 3 & 3 & 3 & 3 & 2 & 70,8 & Baik \\
\hline \multicolumn{8}{|l|}{ Total Rata-rata } & 66,7 & Baik \\
\hline Gajah Mada & 1 & 2 & 3 & 3 & 2 & 3 & 3 & 66,7 & Baik \\
\hline \multicolumn{8}{|l|}{ Total Rata-rata } & 66,7 & Baik \\
\hline \multirow[t]{4}{*}{ Diponegoro } & 1 & 3 & 3 & 3 & 3 & 3 & 3 & 75 & Baik \\
\hline & 2 & 3 & 2 & 2 & 3 & 3 & 3 & 62,5 & Baik \\
\hline & 3 & 3 & 3 & 3 & 3 & 2 & 3 & 75 & Baik \\
\hline & 4 & 3 & 3 & 2 & 3 & 3 & 3 & 66,7 & Baik \\
\hline \multicolumn{8}{|l|}{ Total Rata-rata } & 69,8 & Baik \\
\hline \multicolumn{10}{|l|}{ Keterangan : } \\
\hline
\end{tabular}

\section{Jalan Cut Nyak Dien}

Segmen 1, penilaian pada segmen ini menunjukkan bahwa 79,2\% dari 6 kriteria terpenuhi dan termasuk kedalam kategori baik. Keadaan tanaman pada median jalan terawat dengan baik. Pohon, perdu dan penutup tanah terlihat terawat, daun segar. Pada kedua sisi jalan terdapat pohon mahoni dengan keadaan baik, percabangan pohon yang baik, pohon dalam keadaan subur. Pemangkasan pada median jalan dilakukan tiap hari untuk mempertahankan bentuk awal. Penyiraman dilakukan setiap pagi dan subuh, untuk pemangkasan dilakukan tiap hari pada pagi hari dan juga penyiangan.

Segmen 2, penilaian pada segmen ini menunjukkan bahwa 75\% dari 6 kriteria terpenuhi dan termasuk kedalam kategori baik. Pada segmen ini pemeliharaan dilakukan terhadap pohon palem, pohon mahoni dan soka. Keadaan tanaman 
tersebut terawat. Soka dipangkas sesuai dengan tinggi yang sudah direncanakan pada desain awal. Hanya saja ada beberapa pohon soliter yang dibiarkan tumbuh pada tepi jalan.

Segmen 3, penilaian pada segmen ini menunjukkan bahwa 79,2\% dari 6 kriteria terpenuhi dan termasuk kedalam kategori baik. Pada segmen ini pohon pada kedua sisi jalan seperti mahoni terawat baik. Cemara lilin yang ditanam pada satu sisi pun dalam kondisi baik. Pemangkasan dilakukan apabila ada tajuk atau ranting yang menganggu dan merusak fungsi awal tanaman. Pemangkasan pada median jalan dilakukan tiap hari untuk mempertahankan bentuk awal. Penyiraman dilakukan setiap pagi dan subuh, untuk pemangkasan dilakukan tiap hari pada pagi hari dan juga penyiangan.

Segmen 4, penilaian pada segmen ini menunjukkan bahwa $75 \%$ dari 6 kriteria terpenuhi dan termasuk kedalam kategori baik. Pada segmen ini keadaan pohon sepanjang jalan baik, subur dan terwat. Perawatan dilakukan pada pohon seperti pemangkasan pada tajuk yang menganggu keadaan jalan. Hanya saja ada satu ruas jalan seperti di depan kantor Limnas dan tata ruang tidak terdapat pohon tepi jalan. Penyulaman tidak dilakukan pada ruas jalan ini. Pohon diganti dengan penempatan planting box dari ban karet yang ditanami perdu.

\section{Jalan Sudirman}

Segmen 1, penilaian pada segmen ini menunjukkan bahwa 62,5\%dari 6 kriteria terpenuhi dan termasuk kedalam kategori baik. Pada segmen ini keadaan median jalan baik dan terawat pada umumnya. Planting box yang ditanami perdu terawat, perdu dipangkas teratur. Pohon angsana sepanjang median jalan pun dalam keadaan baik dengan percabangan yang baik dan melebar. Pemeliharaan dilakukan sesuai kebutuhan tanaman. Pada Gambar 42 dapat dilihat keadaan kurangnya penyulaman tanaman pada Jalan Sudirman segmen 1.

Segmen 2, penilaian pada segmen ini menunjukkan bahwa 66,7\% dari 6 kriteria terpenuhi dan termasuk kedalam kategori baik. Pada segmen ini keadaan pohon baik. Perawatan dilakukan dengan baik sehingga pohon angsana dapat memiliki cabang yang baik dan rimbun. Rumput sebagai penutup tanah juga dipelihara 
dengan baik. Pada beberapa ruas terdapat rumput yang gundul dan belum dilakukan penyulaman kembali sehingga penutupan rumput tidak sempurna.

Segmen 3, penilaian pada segmen ini menunjukkan bahwa 62,5\% dari 6 kriteria terpenuhi dan termasuk kedalam kategori baik. Pada segmen ini median jalan ditanami pohon angsana dan perdu. Keadan pohon angsana dan pohon mahoni yang ditanam sepanjang kedua sisi jalan dalam keadaan baik. Perdu yang ditanam pada median jalan pun terpelihara dengan baik. Pemangkasan dan penyiangan serta penyiraman dilakukan secara teratur setiap harinya. Pada beberapa ruas jalan terdapat median jalan yang keadaan penutup tanah dan perdunya dalam keadaan kurang terawat sebab masih kurang penyulaman dan layu.

Segmen 4, penilaian pada segmen ini menunjukkan bahwa 70,8\% dari 6 kriteria terpenuhi dan termasuk kedalam kategori baik. Pada segmen ini keadaan tanaman jalur hijau baik itu median dan tepi jalan dalam keadaan terawat. Median jalan yang memiliki kombinasi pohon perdu dan penutup tanah yang memerlukan perawatan intensif. Pemangkasan, penyiangan dan penyiraman pada tanaman di median jalan ini dilakukan secara rutin setiap harinya agar tetap menjaga desain awal tanaman.

Segmen 5, penilaian pada segmen ini menunjukkan bahwa 70,8\%dari 6 kriteria terpenuhi dan termasuk kedalam kategori baik. Pada segmen ini pohon mahoni yang berumur muda tumbuh dengan subur dan memiliki percabangan yang baik. median jalan yang ditanami bintaro, perdu dan penutup tanah dalam keadaan baik, daun segar dan percabangan baik. Pemeliharaan dilakukan dengan pemangkasan perdu dan cabang agar memperlihatkan bentuk yang sesuai desain awal dan fungsinya. Penyiangan dan penyiraman juga dilakukan dengan baik.

Segmen 6, penilaian pada segmen ini menunjukkan bahwa 62,5\% dari 6 kriteria terpenuhi dan termasuk kedalam kategori baik. Pada segmen ini pinggiran jalan ditanami pohon mahoni dan pohon- pohon yang tumbuh liar di tepi jalan. Keadaan pohon-pohon ini dalam keadaan baik.

Segmen 7, penilaian pada segmen ini menunjukkan bahwa 66,7\% dari 6 kriteria terpenuhi dan termasuk kedalam kategori baik. Keadaan median jalan yang ditanami kombinasi pohon dan perdu dalam keadaan terawat rapi. Pemeliharaan dilakukan setiap harinya, seperti pemangkasan, penyiangan, penyulaman, dan 
penyiraman. Pada kedua sisi jalan pohon mahoni berjejer sepanjang jalan. Hampir kedua ruas jalan pada segmen ini ditanami pohon yang terawat baik.

Segmen 8, penilaian pada segmen ini menunjukkan bahwa 70,8\% dari 6 kriteria terpenuhi dan termasuk kedalam kategori baik. Pada segmen ini keadaan tanaman tumbuh subur, baik dan terawat. Keadaan pohon kelapa sawit kedua sisi jalan dalam keadaan baik, begitu juga beberapa pohon liar yang tumbuh alami di sepanjang jalan. Median jalan ditanami pohon kembang nusa indah, bougenvil dan palem merah dan perdu terlihat dalam keadaan rapi. Perawatan seperti pemangkasan, penyiangan dan penyiraman serta pengendalian HPT dilakukan dengan baik.

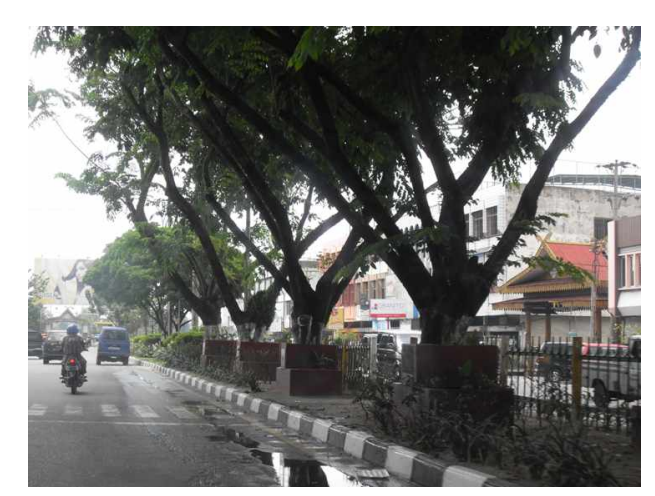

Gambar 42. Keadaan Median Jalan Sudirman yang Kurangnya Penyulaman

\section{Jalan Gajah Mada}

Segmen 1, penilaian pada segmen ini menunjukkan bahwa 66,7\% dari 6 kriteria terpenuhi dan termasuk kedalam kategori baik. Pada segmen ini perawatan sangat mudah untuk kedua sisi jalan yang ditanami pohon mahoni. Perawatan yang intensif seperti pemangkasan, penyiangan dan penyiraman dilakukan terhadap median jalan dan planting box. Setiap harinya pekerja melakukan pemeliharaan pada ruas jalan ini sehingga keadaan tanaman pada ruas jalan ini baik.

\section{Jalan Diponegoro}

Segmen 1, penilaian pada segmen ini menunjukkan bahwa $75 \%$ dari 6 kriteria terpenuhi dan termasuk kedalam kategori baik. Pada segmen ini pemeliharaan dilakukan dengan baik. Hal ini terlihat pada keadaan lapang dimana median jalan yang ditanami dengan kombinasi pohon dan perdu terawat dengan baik. 
pemangkasan, penyiangan dan penyiraman dilakukan setiap harinya. Pada tanaman yang berbunga di median jalan juga diberi pupuk agar tanaman dapat berbunga dengan baik. Hal ini terlihat dari bunga mawar yang berbunga indah pada median jalan. Pada kedua sisi jalan pohon-pohon juga terawat baik terlihat dari rimbunnya daun dan percabangan yang baik.

Segmen 2, penilaian pada segmen ini menunjukkan bahwa 62,5\% dari 6 kriteria terpenuhi dan termasuk kedalam kategori baik. Pada segmen ini planting box yang berisi bougenvil membutuhkan perawatan intensif seperti pemangkasan agar bentu dan tinggi tetap terjaga. Pada median pemeliharaan masih sama dengan segmen satu, keadaan median juga dalam keadaan terawat dan rapi. Tidak dijumpai tanaman layu atau tanaman liar.

Segmen 3, penilaian pada segmen ini menunjukkan bahwa $75 \%$ dari 6 kriteria terpenuhi dan termasuk kedalam kategori baik. Pada segmen ini median jalan terawat dengan baik. Pemeliharaan yang dilakukan masih sama dengan median jalan sebelumnya. Pada satu sisi jalan pohon glodogan tiang dalam keadaan baik dengan rimbunnya daun dan percabangan yang baik. Pada satu sisi jalan yang lain ditanami pohon mahoni yang berumur muda dan membutuhkan penyiraman dan pemupukan agar pohon ini dapat tumbuh subur dan bercabang dengan baik.

Segmen 4, penilaian pada segmen ini menunjukkan bahwa 66,7\% dari 6 kriteria terpenuhi dan termasuk kedalam kategori baik. Pada segmen jalan ini keadaan median jalan dalam keadaan baik dan terawat. Pemangkasan, penyiangan dan penyiraman dilakukan teratur setiap harinya pada perdu di median jalan. Pada kedua sisi pohon tumbuh dengan baik, subur, rimbun. Hanya saja setelah bundaran keris terdapat ruas jalan yang tidak ditanami pohon atau penyulaman tidak dilakukan pada ruas jalan tersebut. Pada gambar 43 dapat dilihat bentuk kegiatan pemeliharaan pada jalur hijau jalan. 


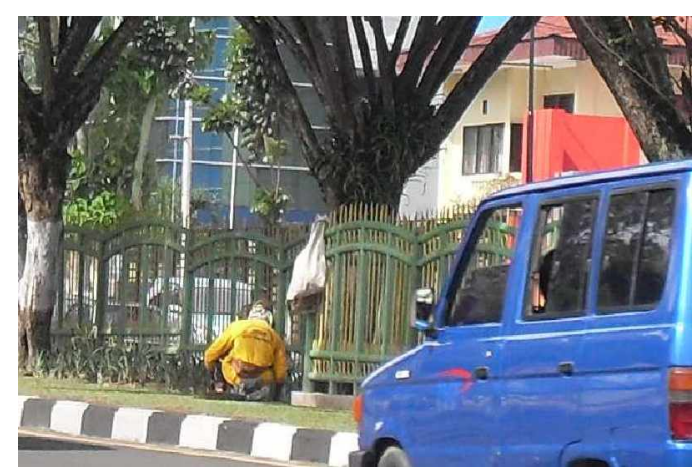

Gambar 43. Kegiatan Pemeliharaan Jalur Hijau di Jalan Sudirman

Pengorganisasian dan perencanaan program pemeliharaan yang baik dapat memudahkan pemeliharaan tanaman dari segi teknis (Vitasari, 2004). Pemeliharaan fisik yang sering terabaikan adalah penyiangan gulma yang kehadirannya tidak diinginkan sehingga dapat mengurangi estetika pada lanskap jalan dan menggangu pemandangan. Pemeliharaan dari segi teknis didukung oleh jadwal yang terencana baik dan efektifitas kerja pegawainya di lapang. Penampakan tanaman yang baik di lapang dari segi fungsional dan estetika merupakan indikator keberhasilan pengelolaan.

\section{Penilaian Seluruh Aspek Pengelolaan Tanaman Lanskap Jalan Pada Setiap Segmen Jalan}

Nilai kedua aspek pengelolaan per segmen jalan dirangkum pada Tabel 31. Segmen jalan yang termasuk kedalam kategori baik yaitu : Jalan Cut Nyak Dien segmen 1 (68,8\%), 2 (70,9\%), 3 (68,8\%), dan 4 (70,9\%), Jalan Sudirman segmen 1 (60,4\%), 2 (70,9\%), $3(68,8 \%), 5(64,6 \%), 6(77,1 \%), 7(66,7 \%)$, dan 8 $(68,8 \%)$, Jalan Gajah Mada segmen 1 (62,5\%), Jalan Diponegoro segmen 1 $(66,7 \%), 2(60,4 \%), 3(66,7 \%)$, dan $4(62,5 \%)$; kategori sedang yaitu : Jalan Sudirman segmen $4(56,3 \%)$.

Pada Tabel didapatkan segmen jalan umumnya memiliki kategori baik yaitu terdapat 16 segmen jalan berkategori baik. Rata-rata nilai aspek pengelolaan antara 63,7\% - $70 \%$ termasuk kategori baik. Hasil yang baik di lapang didukung oleh jadwal kerja yang baik dan kedisiplinan pekerja. Pengelolaan dari segi desain dan teknis dilakukan dengan baik. Pengelolaan yang lebih baik lagi dari segi 
teknis perlu ditingkakan dan dari harus didukung dari segi desain agar tercipta lanskap yang berkelanjutan.

Tabel 32. Penilaian Seluruh Aspek Pengelolaan Tanaman

Keterangan : Sangat Baik bila $/ 81 \% \quad$ Baik bila $61-80 \%$

Sedang bila $41-60 \% \quad$ Buruk bila [ $40 \%$ 


\section{Gabungan Penilaian Aspek Fungsi, Estetika, dan Pengelolaan pada Tiap Segmen Jalan}

Setelah dilakukan penilaian pada ketiga aspek yaitu fungsional, esetika dan pengelolaan maka dilakukan penggabungan nilai dari ketiga aspek. Gabungan nilai dapat dilihat pada Tabel 33.

Pada Tabel 33 dapat dilihat segmen 8 pada jalan Sudirman umumnya memilki nilai baik untuk ketiga aspek yang dievaluasi. Pada segmen ini nilai fungsional dan pengelolaannya dalam ketegori baik dan untuk nilai estetika umumnya memiliki keindahan pemandangan tinggi untuk massal campuran. Pada Jalan Sudirman segmen 6 memiliki nilai fungsional sangat baik dan pengelolaan baik dan segmen 7 yang memiliki fungsional dan pengelolaan yang baik umumnya memiliki nilai estetika keindahan pemandangan tinggi untu pohon massal sejenis. Pada segmen 4 di Jalan Cut Nyak Dien nilai fungsional dan pengelolaan termasuk kategori baik, tetapi untuk nilai estetika umumnya memiliki keindahan pemandangan rendah pada penataan pohon massal sejenis. Pada segmen 1 di Jalan Sudirman juga umumnya memiliki nilai keindahan pemandangan rendah untuk penataan pohon massal sejenis, tetapi nilai fungsional dan pengelolaan termasuk kategori baik. 
Tabel 33. Gabungan Penilaian Aspek Fungsional, Estetika, dan Pengelolaan

\begin{tabular}{|c|c|c|c|c|c|c|c|c|c|c|c|c|c|}
\hline \multirow[t]{4}{*}{ Jalan } & \multirow[t]{4}{*}{ Segmen } & \multicolumn{12}{|c|}{ Penilaian (Kategori) } \\
\hline & & \multirow[t]{3}{*}{ Fungsional } & \multirow[t]{3}{*}{ Pengelolaan } & \multicolumn{10}{|c|}{ Estetika } \\
\hline & & & & \multirow[t]{2}{*}{$\begin{array}{l}\text { Lanskap/ } \\
\text { Gambar }\end{array}$} & \multicolumn{3}{|c|}{$\begin{array}{l}\text { Pohon } \\
\text { massal } \\
\text { Sejenis }\end{array}$} & \multicolumn{3}{|c|}{\begin{tabular}{|l|} 
Pohon \\
Kelompok \\
Campuran
\end{tabular}} & \multicolumn{3}{|c|}{$\begin{array}{l}\text { Massal } \\
\text { Campuran }\end{array}$} \\
\hline & & & & & $\mathrm{T}$ & $\mathrm{S}$ & $\mathrm{R}$ & $\mathrm{T}$ & $\mathrm{S}$ & $\mathrm{R}$ & $\mathrm{T}$ & $\mathrm{S}$ & $\mathrm{R}$ \\
\hline \multirow{12}{*}{$\begin{array}{ll}\text { Cut } & \text { Nyak } \\
\text { Dien } & \end{array}$} & \multirow[t]{3}{*}{1} & \multirow[t]{3}{*}{ Baik } & \multirow[t]{3}{*}{ Baik } & 3 & & & & & & $\mathrm{v}$ & & & \\
\hline & & & & 1 & & & & & & & & & $\mathrm{v}$ \\
\hline & & & & 3 & & & & & & & & $\mathrm{v}$ & \\
\hline & 2 & Sedang & Baik & 1 & & & & & & $\mathrm{v}$ & & & \\
\hline & \multirow[t]{3}{*}{3} & \multirow[t]{3}{*}{ Baik } & \multirow[t]{3}{*}{ Baik } & 5 & & $\mathrm{v}$ & & & & & & & \\
\hline & & & & 6 & & $\mathrm{v}$ & & & & & & & \\
\hline & & & & 2 & & & & & & & & & $\mathrm{v}$ \\
\hline & \multirow[t]{5}{*}{4} & \multirow[t]{5}{*}{ Baik } & \multirow[t]{5}{*}{ Baik } & 1 & & & $\mathrm{v}$ & & & & & & \\
\hline & & & & 2 & & & $\mathrm{v}$ & & & & & & \\
\hline & & & & 3 & & & $\mathrm{v}$ & & & & & & \\
\hline & & & & 4 & & $\mathrm{v}$ & & & & & & & \\
\hline & & & & 2 & & & & & & $\mathrm{v}$ & & & \\
\hline \multirow[t]{26}{*}{ Sudirman } & 1 & Baik & Baik & 11 & & & & & & & & & $\mathrm{v}$ \\
\hline & & & & 12 & & & & & & & & & $\mathrm{v}$ \\
\hline & & & & 13 & & & & & & & & & $\mathrm{v}$ \\
\hline & & & & 23 & & & & & & & & & $\mathrm{v}$ \\
\hline & 2 & Baik & Baik & 11 & & & & $\mathrm{v}$ & & & & & \\
\hline & & & & 22 & & & & & & & & $\mathrm{v}$ & \\
\hline & 3 & Baik & Baik & 22 & & $\mathrm{v}$ & & & & & & & \\
\hline & & & & 24 & & & & & & & & & $\mathrm{v}$ \\
\hline & & & & 12 & & & & & $\mathrm{v}$ & & & & \\
\hline & 4 & Baik & Sedang & 21 & & & & & & & $\mathrm{v}$ & & \\
\hline & & & & 26 & & & & & & & & $\mathrm{v}$ & \\
\hline & 5 & Baik & Baik & 20 & & & & & & & & $\mathrm{v}$ & \\
\hline & 6 & Sangat Baik & Baik & 14 & & $\mathrm{v}$ & & & & & & & \\
\hline & & & & 15 & $\mathrm{v}$ & & & & & & & & \\
\hline & & & & 16 & $\mathrm{v}$ & & & & & & & & \\
\hline & & & & 21 & $\mathrm{v}$ & & & & & & & & \\
\hline & & & & 6 & & & & & & $\mathrm{v}$ & & & \\
\hline & & & & 7 & & & & & & $\mathrm{v}$ & & & \\
\hline & & & & 8 & & & & $\mathrm{v}$ & & & & & \\
\hline & & & & 9 & & & & & $\mathrm{v}$ & & & & \\
\hline & & & & 10 & & & & $\mathrm{v}$ & & & & & \\
\hline & 7 & Baik & Baik & 17 & $\mathrm{v}$ & & & & & & & & \\
\hline & & & & 18 & $\mathrm{v}$ & & & & & & & & \\
\hline & & & & 19 & & & $\mathrm{v}$ & & & & & & \\
\hline & & & & 20 & $\mathrm{v}$ & & & & & & & & \\
\hline & & & & 19 & & & & & & & & & $\mathrm{v}$ \\
\hline
\end{tabular}




\begin{tabular}{|c|c|c|c|c|c|c|c|c|c|c|c|c|c|}
\hline \multirow[t]{4}{*}{ Jalan } & \multirow[t]{4}{*}{ Segmen } & \multicolumn{12}{|c|}{ Penilaian (Kategori) } \\
\hline & & \multirow[t]{3}{*}{ Fungsional } & \multirow[t]{3}{*}{ Pengelolaan } & \multicolumn{10}{|c|}{ Estetika } \\
\hline & & & & \multirow[t]{2}{*}{\begin{tabular}{|l|} 
Lanskap \\
\end{tabular}} & \multicolumn{3}{|c|}{$\begin{array}{l}\text { Pohon } \\
\text { massal } \\
\text { Sejenis }\end{array}$} & \multicolumn{3}{|c|}{$\begin{array}{l}\text { Pohon } \\
\text { Kelompok } \\
\text { Campuran }\end{array}$} & \multicolumn{3}{|c|}{$\begin{array}{l}\text { Massal } \\
\text { Campuran }\end{array}$} \\
\hline & & & & & $\mathrm{T}$ & $\mathrm{S}$ & $\mathrm{R}$ & & $\mathrm{s}$ & $\bar{R}$ & $\mathrm{~T}$ & $\mathrm{~s}$ & $\mathrm{R}$ \\
\hline & \multirow[t]{6}{*}{8} & \multirow[t]{6}{*}{ Baik } & \multirow[t]{6}{*}{ Baik } & 12 & $\mathrm{v}$ & & & & & & & & \\
\hline & & & & 14 & & & & & & & $\mathrm{v}$ & & \\
\hline & & & & 15 & & & & & & & $\mathrm{v}$ & & \\
\hline & & & & 16 & & & & & & & $\mathrm{v}$ & & \\
\hline & & & & 17 & & & & & & & & & $\mathrm{v}$ \\
\hline & & & & 18 & & & & & & & & $\mathrm{v}$ & \\
\hline \multirow[t]{4}{*}{ Gajah Mada } & \multirow[t]{4}{*}{1} & \multirow[t]{4}{*}{ Sedang } & \multirow[t]{4}{*}{ Baik } & 7 & & $\mathrm{v}$ & & & & & & & \\
\hline & & & & 8 & & & $\mathrm{v}$ & & & & & & \\
\hline & & & & 9 & & & & & & & & $\mathrm{v}$ & \\
\hline & & & & 25 & & & & & & & $\mathrm{v}$ & & \\
\hline \multirow[t]{10}{*}{ Diponegoro } & \multirow[t]{4}{*}{1} & \multirow[t]{4}{*}{ Baik } & \multirow[t]{4}{*}{ Baik } & 9 & & $\mathrm{v}$ & & & & & & & \\
\hline & & & & 4 & & $\mathrm{v}$ & & & & & & & \\
\hline & & & & 5 & & $\mathrm{v}$ & & & & & & & \\
\hline & & & & 6 & & $\mathrm{v}$ & & & & & & & \\
\hline & \multirow[t]{3}{*}{2} & \multirow[t]{3}{*}{ Sedang } & \multirow[t]{3}{*}{ Baik } & 5 & & & & & $\mathrm{v}$ & & & & \\
\hline & & & & 7 & & & & & & & & $\mathrm{v}$ & \\
\hline & & & & 8 & & & & & & & & $\mathrm{v}$ & \\
\hline & \multirow[t]{2}{*}{3} & \multirow[t]{2}{*}{ Baik } & \multirow[t]{2}{*}{ Baik } & 10 & $\mathrm{v}$ & & & & & & & & \\
\hline & & & & 4 & & & & & $\mathrm{v}$ & & & & \\
\hline & 4 & Baik & Baik & 11 & & & $\mathrm{v}$ & & & & & & \\
\hline
\end{tabular}

Keterangan :

$\mathrm{T}$ : Tinggi

$S$ : Sedang

$\mathrm{R}$ : Rendah 


\section{REKOMENDASI}

\section{Aspek Fungsi}

1. Penilaian kategori sangat baik

Kategori sangat baik perlu untuk dipertahankan dan menjadi contoh bagi segmen jalan lainnya. Pada rata-rata seluruh kriteria fungsi (Tabel 17) dapat terlihat Jalan Sudirman segmen 6 termasuk kedalam kategori sangat baik. Seluruh fungsi diantaranya pengarah, peneduh, pembatas, pemberi identitas, kontrol silau matahari, kontrol polusi, dan kontrol bunyi dapat terpenuhi dengan baik. Tanaman pada jalan ditanam secara massal sejenis dengan tajuk saling bersinggungan, memiliki ciri khas tertentu, menyerap polutan dengan baik, dan ditanam liniear sepanjang jalan menjadi pengarah visual yang baik.

2. Penilaian kategori baik dan Sedang

Keadaan kategori baik dan sedang perlu untuk dipertahankan dan ditingkatkan pemenuhan setiap kriteria fungsi tanaman agar menjadi lebih baik. Penanaman tanaman massal sejenis, secara berkesinambungan, jarak tanam rapat, penutupan tajuk merata perlu dilakukan. Selain itu diperlukan juga peningkatan penanaman semak/perdu yang rimbun, beberapa lapis tanaman, penanaman kombinasi pohon, perdu/semak, penutup tanah, tanaman berkapasitas mengurangi polutan, dan tanaman yang memiliki ciri khas kuat, pola menarik dan asli daerah pada median atau tepi jalan. Pada jalan yang tidak memiliki median dibutuhkan penanaman pohon dengan jarak rapat dan juga penambahan planting box. Pada rata-rata seluruh nilai kriteria fungsi (Tabel 17) dapat terlihat Jalan Cut Nyak Dien segmen 1, 3, dan 4, Jalan Sudirman segmen 1, 2, 3, 4, 5, 7, dan 8, Jalan Diponegoro segmen 1, 3, dan 4 termasuk kedalam kategori baik dan Jalan Cut Nyak Dien segmen 2, Jalan Diponegoro segmen 2 dan Jalan Gajah Mada segmen 1 termasuk kedalam kategori sedang. Rekomendasi dapat dilihat pada Tabel 36. 


\section{Aspek Estetika}

\section{Keindahan Pemandangan Tinggi}

Keindahan lanskap tinggi perlu untuk dipertahankan dengan cara pemeliharaan yang direncanakan dengan baik dan dilakukan secara teratur. Pada lanskap pohon massal sejenis dengan keindahan pemandangan tinggi memilkikriteria pananaman seperti pohon massal sejenis ditanam dengan jarak rapat, berkesinambungan, berjejer memiliki pola liniear, memiliki keseragaman bentuk tajuk dan tinggi, tajuk bersinggungan. Pada lanskap pohon kelompok campuran dengan kriterianya seperti kesatuan antar kelompok pohon baik dalam bentuk tajuk, warna dan tekstur. Keharmonisan yang terbentuk dari kumpulan pohon campuran yang serasi dalam komposisi dan proporsi. Pada lanskap massal campuran (pohonperdu-penutup tanah) kriterianya seperti kesatuan antar kelompok pohon baik dalam bentuk tajuk, warna dan tekstur. Keharmonisan yang terbentuk dari kumpulan pohon campuran yang serasi dalam komposisi dan proporsi.

2. Keindahan Pemandangan Sedang dan Rendah

Pada lanskap dengan keindahaan pemandangan sedang dan rendah perlu dilakukan peningkatan pemenuhan kriteria penanaman.

Pada lanskap pohon massal sejenis, pohon yang ditanam dengan jarak renggang perlu dilakukan penyulaman pohon agar terlihat rapat. Bentuk tajuk tidak seragam perlu untuk diseragamkan dengan membantu pertumbuhan cabang pohon dan menyempurnakan bentuk tajuk. Susunan pohon yang tidak teratur perlu dibenahi, penyulaman pohon pada daerah yang jarang pohon atau jarang tanam renggang. Penyatuan dan keseraaman tinggi, bentuk tajuk pohon massal sejenis diperlukan untuk menciptakan keindahan yang tinggi. Pemeliharaan pohon massal sejenis dibutuhkan agar menciptakan suatu keseragaman dan unity.

Pada lanskap massal campuran (pohon-perdu-penutup tanah), penanaman memeperhatikan keseimbangan kombinasi, memaksimalkan pertumbuhan tanaman, penyulaman tanaman perlu ditingkatkan penataan yang lebih teratur dan rapi agar 
kombinasi tanaman tidak terlihat kacau dan tumpang tindih. Perlu memperhatikan pemeliharaan agar desain tetap terjaga dan penggurangan variasi tanaman, memilih kombinasi yang saling mendukung dan serasi.

Pada lanskap pohon kelompok campuran, variasi pohon yang sesuai, penanaman yang teratur di sepanjng jalan, penambahan tanaman pada jarak tanam yang tidak rapat, membantu pertumbuhan pohon agar maksimal, dan penambahan pohon yang sesuai dan saling mendukung. Kombinasi pohon yang dipilih haruslah mempertimbangkan keserasian dan jangan terlalu banyak variasi. Pemeliharaan pohon yang baik agar tercipta suatu lanskap yang indah dan rapi. Rekomendasi dapat dilihat pada Tabel 37.

\section{Aspek Pengelolaan}

1. Penilaian kategori baik

Pada rata-rata seluruh nilai kriteria pengelolaan (Tabel 32) dapat terlihat Jalan Cut Nyak Dien segmen 1, 2, 3, 4, Jalan Sudirman segmen 1, 2, 3, 5, 6, 7, 8, Jalan Gajah Mada segmen 1, dan Jalan Diponegoro segmen 1, 2, 3, 4 termasuk kedalam kategori baik. Keadaan ini perlu untuk dipertahankan dan dilanjutkan. Pengelolaan yang sudah baik dan terjadwal akan membantu dalam mempertahankan keadaan jalur hijau jalan. Peningkatan dalam pemeliharaan masih perlu dilakukan agar fungsi dan estetika tanaman lanskap jalan dapat berkelanjutan. Penggunaan pola yang sederhana dan penataan tanaman secara massal akan membantu mempermudah pemeliharaan.

2. Penilaian kategori sedang

Pada rata-rata seluruh nilai kriteria fungsi (Tabel 32) dapat terlihat Jalan Sudirman segmen 3 termasuk kedalam kategori sedang. Pada segmen jalan ini masih diperlukan pemeliharaan yang lebih baik. Pemeliharaan dari segi teknis yang terjadwal dengan baik. Pada segmen ini penyulaman pada median jalan kurang dilakukan sehingga estetika tanaman tidak tercipta. Selain itu terdapat tanaman yang layu yang membutuhkan pemeliharaan yang baik. pada segi desain dibutuhkan pola tanaman yang lebih sederhan untuk memudahkan pemeliharaan. Pemeliharaan secara 
teknis seperti pemangkasan, penyiraman, pemupukan, penyulaman, pengendalian HPT, dan penyiangan gulma. Pola tanaman juga perlu untuk diperhatikan untuk mempermudah pemeliharaan. Kerumitan suatu desain akan membuat pemeliharaan yang dilakukan semakin intensif sehingga mengeluarkan biaya, tenaga yang lebih. Pada jalan sebaiknya menggunakan tanaman massal, keragaman yang tidak tinggi, dan menggurangi bentukan seperti topiary lebih baik dikurangi. Penataan secara massal dan penyulaman perlu untuk dilakukan. Kegiatan pemeliharaan yang perlu dilakukan dapat dilihat pada Tabel 34. Rekomendasi dapat dilihat pada Tabel 38.

Tabel 34. Kegiatan pemeliharaan pasca panen dan rutin

\begin{tabular}{|c|c|}
\hline Kegiatan & Keterangan \\
\hline Penyiraman & $\begin{array}{l}\text { Dilakukan rutin tiap hari terutama pada musim kemarau (pagi pukul } \\
06.00-09.00 \text { dan sore pukul } 15.00-18.00 \text { ) }\end{array}$ \\
\hline Penyiangan & $\begin{array}{l}\text { Dilakukan minimal } 1 \text { bulan sekali, tanaman liar dicabut sampai ke } \\
\text { akar kecuali pohon }\end{array}$ \\
\hline Pemangkasan & $\begin{array}{l}\text { - Pohon, perdu dan semak : dilakukan miring }\left(45^{\circ}\right) \text { dan rata, arah } \\
\text { pangkas dari bawah ke atas, dilakukna pemupukan setelah } \\
\text { pemangkasan } \\
\text { Rumput : dipangkas dengan tebal rumput }+5 \mathrm{~cm} \text { dari } \\
\text { permukaan tanah, dilakukan pengerekan pada rumput bagian } \\
\text { tepi }\end{array}$ \\
\hline Pemupukan & $\begin{array}{l}\text { Pemupukan dilakukan minimal } 1 \text { bulan sekali setalah tanam dan } 1 \\
\text { bulan sekali setelahnya, pemupukan dengan pupuk anorganik } \\
\text { dengan campuran pupuk dan air lalu disemprotkan dan disiram, } \\
\text { pemupukan dengan pupuk kandang dengan ditaburkan dan ditutup } \\
\text { tanah subur }\end{array}$ \\
\hline $\begin{array}{l}\text { Pencegahan dan pemberantasan } \\
\text { hama/penyakit }\end{array}$ & $\begin{array}{l}\text { Pemberantasan hama dengan insektisida berulang tiap } 1 \text { minggu } \\
\text { sekali sampai bebas hama, pemeberantasan penyakit digunakan } \\
\text { fungsida } 1 \text { minggu sekali, bila penyakitnya berat maka tanaman } \\
\text { dibongkar lalu ditanam kemabali, bila terjadi serangan bersama } \\
\text { maka dapat diberikan campuran insektisida dan fungisida }\end{array}$ \\
\hline Penggantian tanaman & $\begin{array}{l}\text { Pohon dapat dilakukan dengan mencabut pohon lalu membuat } \\
\text { lubang (pohon; } 1 \mathrm{mx} 1 \mathrm{~m} \times 1 \mathrm{~m} \text { semak; } 60 \mathrm{~cm} \times 40 \mathrm{~cm} \text { ), isi lubang } \\
\text { dengan komposisi tanah subur dan pupuk kandang perbandingan } \\
\text { 3:2, lalu masukkan tanaman pengganti, dipadatkan dan disiram }\end{array}$ \\
\hline
\end{tabular}

Jadwal pemeliharaan terbagi 2 yaitu pemeliharaan pasca tanam yang dilakukan sejak penanaman sampai 3 bulan berikutnya dan dilakukan secara intensif, pemeliharaan rutin dilakukan pada tanaman lama yang sudah ada dan juga lanjutan setelah pemeliharaan pasca tanam. 
Tabel 35. Rekomendasi Penataan tanaman
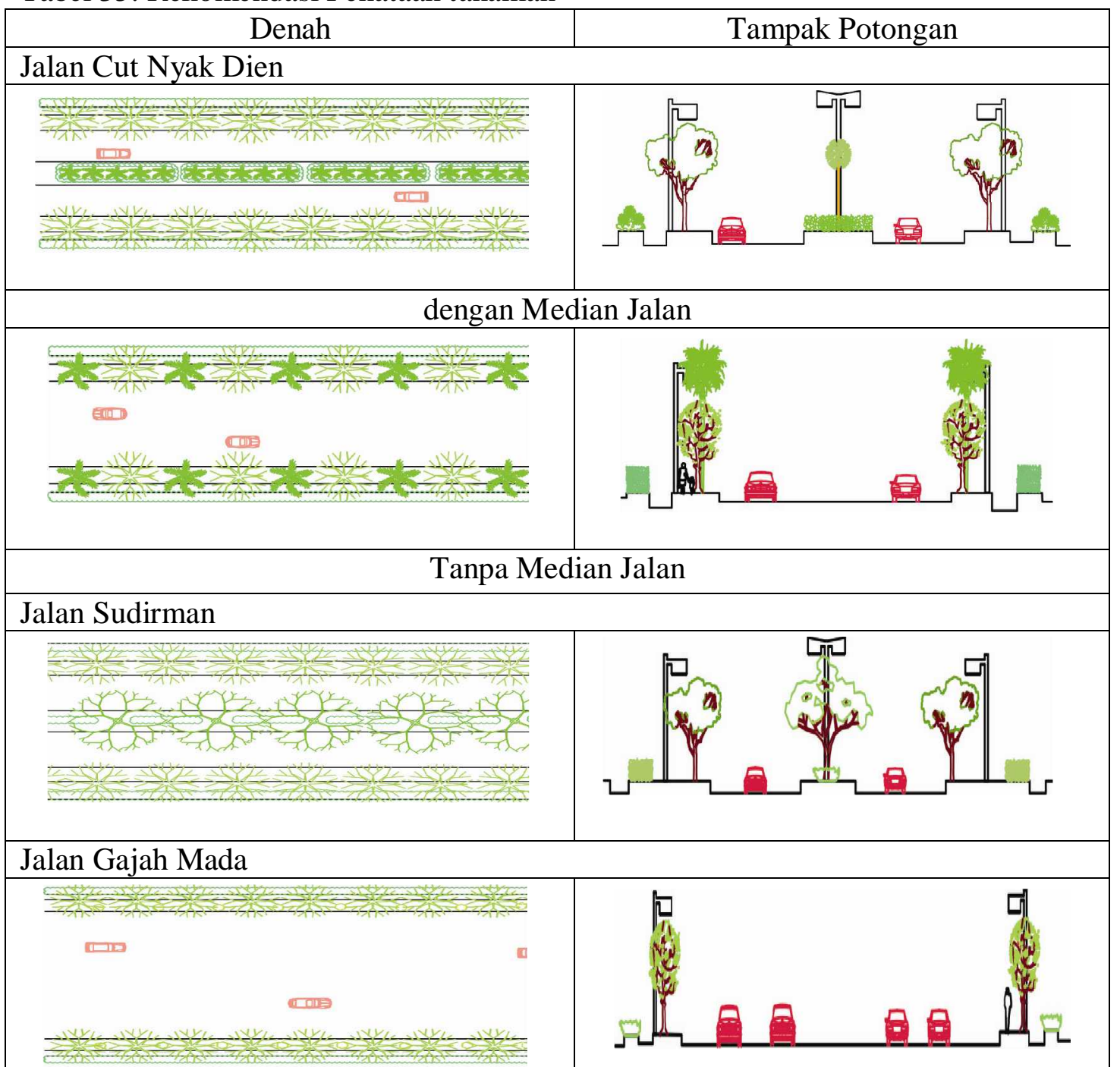

\section{Jalan Diponegoro}
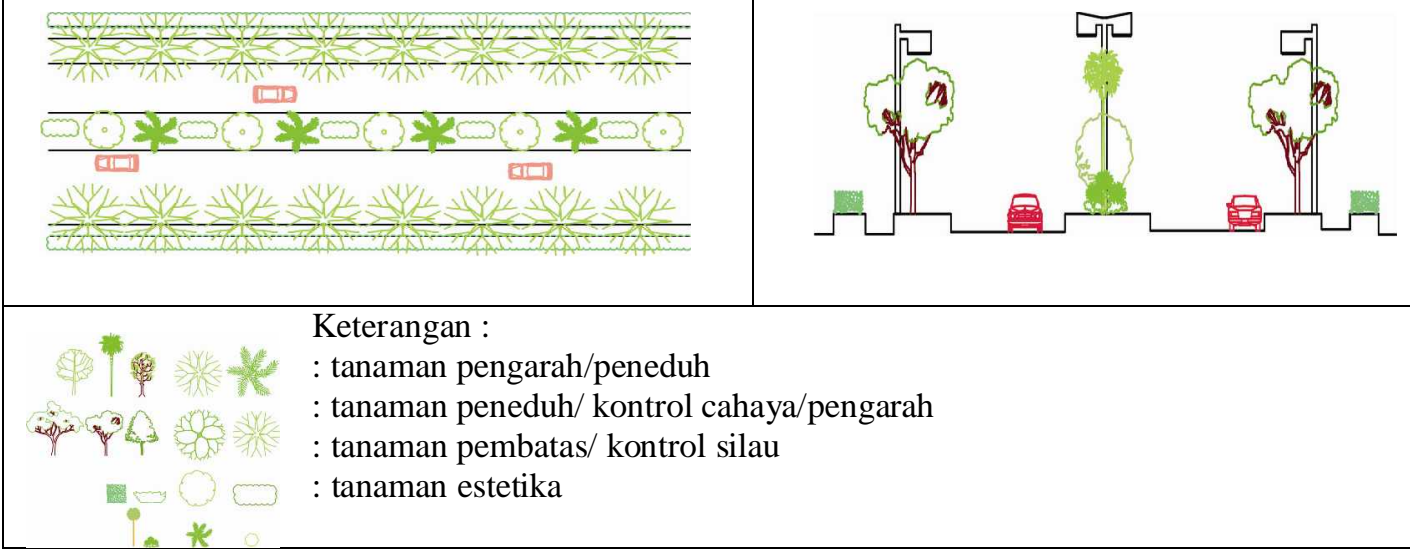
Tabel 36. Rekomendasi Aspek Fungsi Tanaman Lanskap Jalan

\begin{tabular}{|c|c|c|c|c|c|c|c|c|c|c|c|c|c|c|c|c|c|c|}
\hline \multirow[t]{3}{*}{ Fungsi } & \multicolumn{17}{|c|}{ Jalan dan Segmen } & \multirow[t]{3}{*}{ Rekomendasi } \\
\hline & \multicolumn{4}{|c|}{ Cut Nyak Dien } & \multicolumn{8}{|c|}{ Sudirman } & \multirow{2}{*}{$\begin{array}{c}\text { Gajah } \\
\text { Mada } \\
1 \\
\end{array}$} & \multicolumn{4}{|c|}{ Diponegoro } & \\
\hline & 1 & 2 & 3 & 4 & 1 & 2 & 3 & 4 & 5 & 6 & 7 & 8 & & 1 & 2 & 3 & 4 & \\
\hline \multicolumn{19}{|l|}{ 1. Pengarah } \\
\hline Sangat Baik & & & & $\mathrm{V}$ & $\mathrm{v}$ & $\mathrm{v}$ & $\mathrm{v}$ & & & $\mathrm{v}$ & & $\mathrm{V}$ & $\mathrm{v}$ & $\mathrm{v}$ & $\mathrm{V}$ & $\mathrm{v}$ & $\mathrm{v}$ & $\begin{array}{l}\text { Mempertahankan kondisi yang } \\
\text { telah ada }\end{array}$ \\
\hline Baik & $\mathrm{V}$ & $\mathrm{V}$ & $\mathrm{V}$ & & & & & & $\mathrm{V}$ & & $\mathrm{V}$ & & & & & & & Penambahan penanaman pohon \\
\hline Sedang & & & & & & & & $\mathrm{v}$ & & & & & & & & & & $\begin{array}{l}\text { Penambahan } \begin{array}{r}\text { tanaman } \\
\text { massal/sejenis dengan jarak } \\
\text { tanam rapat }\end{array} \\
\end{array}$ \\
\hline \multirow{2}{*}{\multicolumn{19}{|c|}{$\begin{array}{l}\text { Buruk } \\
\text { 2. Pembatas Visual }\end{array}$}} \\
\hline & & & & & & & & & & & & & & & & & & \\
\hline Sangat Baik & & & & $\mathrm{V}$ & & $\mathrm{V}$ & $\mathrm{v}$ & & & $\mathrm{V}$ & & & & & & & & $\begin{array}{l}\text { Mempertahankan kondisi yang } \\
\text { telah ada }\end{array}$ \\
\hline Baik & $\mathrm{v}$ & & $\mathrm{v}$ & & $\mathrm{v}$ & & & & $\mathrm{v}$ & & $\mathrm{v}$ & $\mathrm{v}$ & $\mathrm{v}$ & $\mathrm{v}$ & $\mathrm{v}$ & $\mathrm{v}$ & $\mathrm{v}$ & $\begin{array}{l}\text { Penanaman dengan jarak tanam } \\
\text { rapat }\end{array}$ \\
\hline Sedang & & $\mathrm{v}$ & & & & & & $\mathrm{v}$ & & & & & & & & & & $\begin{array}{l}\text { Penambahan tanaman dengan } \\
\text { jarak dan massa daun rapat }\end{array}$ \\
\hline \multirow{2}{*}{\multicolumn{19}{|c|}{$\begin{array}{l}\text { Buruk } \\
\text { 3. Peneduh }\end{array}$}} \\
\hline & & & & & & & & & & & & & & & & & & \\
\hline Sangat Baik & & & & & $\mathrm{v}$ & $\mathrm{v}$ & $\mathrm{v}$ & & & $\mathrm{v}$ & & & & $\mathrm{v}$ & & & & $\begin{array}{l}\text { Mempertahankan kondisi yang } \\
\text { telah ada }\end{array}$ \\
\hline Baik & $\mathrm{v}$ & & & $\mathrm{v}$ & & & & $\mathrm{v}$ & $\mathrm{V}$ & & $\mathrm{v}$ & $\mathrm{v}$ & & & & $\mathrm{V}$ & $\mathrm{v}$ & $\begin{array}{l}\text { Peningkatan penutupan tajuk } \\
\text { dan percabangan pohon }\end{array}$ \\
\hline Sedang & & $\mathrm{v}$ & $\mathrm{v}$ & & & & & & & & & & $\mathrm{V}$ & & $\mathrm{v}$ & & & $\begin{array}{l}\text { Penambahan penanaman pohon } \\
\text { tinggi (tajuk pilihan) dan } \\
\text { ditanam teratur }\end{array}$ \\
\hline \multicolumn{19}{|l|}{ Buruk } \\
\hline \multicolumn{19}{|c|}{ 4. Pemberi Identitas } \\
\hline Sangat Baik & & & & & & $\mathrm{v}$ & $\mathrm{v}$ & & & $\mathrm{v}$ & $\mathrm{v}$ & & & $\mathrm{v}$ & & & $\mathrm{v}$ & $\begin{array}{l}\text { Mempertahankan kondisi yang } \\
\text { telah ada }\end{array}$ \\
\hline
\end{tabular}




\begin{tabular}{|c|c|c|c|c|c|c|c|c|c|c|c|c|c|c|c|c|c|c|}
\hline \multirow[t]{3}{*}{ Fungsi } & \multicolumn{17}{|c|}{ Jalan dan Segmen } & \multirow[t]{3}{*}{ Rekomendasi } \\
\hline & \multicolumn{4}{|c|}{ Cut Nyak Dien } & \multicolumn{8}{|c|}{ Sudirman } & \multirow{2}{*}{$\begin{array}{c}\text { Gajah } \\
\text { Mada } \\
1\end{array}$} & \multicolumn{4}{|c|}{ Diponegoro } & \\
\hline & 1 & 2 & 3 & 4 & 1 & 2 & 3 & 4 & 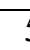 & ( & & $\varepsilon$ & & 1 & 2 & 3 & 4 & \\
\hline \multicolumn{19}{|c|}{ 4. Pemberi Identitas } \\
\hline Baik & & & $\mathrm{V}$ & $\mathrm{V}$ & $\mathrm{V}$ & & & $\mathrm{V}$ & $\mathrm{V}$ & & & $\mathrm{V}$ & $\mathrm{V}$ & & $\mathrm{V}$ & $\mathrm{V}$ & & $\begin{array}{l}\text { Penggunaan tanaman asli } \\
\text { daerah, memperkuat cirri khas } \\
\text { tanaman }\end{array}$ \\
\hline Sedang & $\mathrm{v}$ & $\mathrm{v}$ & & & & & & & & & & & & & & & & $\begin{array}{l}\text { Penanaman dengan pola } \\
\text { menarik dan memilki cirri khas }\end{array}$ \\
\hline \multirow{2}{*}{\multicolumn{19}{|c|}{\begin{tabular}{l|l|l} 
Buruk & & \\
$5 . \quad$ Kontrol Silau Matahari
\end{tabular}}} \\
\hline & & & & & & & & & & & & & & & & & & \\
\hline Sangat Baik & & & & & & & & & & & $\mathrm{v}$ & & & & & & & $\begin{array}{l}\text { Mempertahankan kondisi yang } \\
\text { telah ada }\end{array}$ \\
\hline Baik & $\mathrm{V}$ & & $\mathrm{V}$ & $\mathrm{V}$ & $\mathrm{V}$ & $\mathrm{v}$ & $\mathrm{V}$ & $\overline{\mathrm{V}}$ & $\mathrm{V}$ & $\mathrm{v}$ & & $\mathrm{v}$ & & $\mathrm{V}$ & & $\mathrm{V}$ & $\mathrm{V}$ & $\begin{array}{l}\text { Penanaman semak/perdu yang } \\
\text { rimbun }\end{array}$ \\
\hline Sedang & & $\mathrm{v}$ & & & & & & & & & & & $\mathrm{v}$ & & $\mathrm{v}$ & & & $\begin{array}{l}\text { Penambahan penanaman } \\
\text { semak/perdu secara } \\
\text { berkelompok dan rimbun }\end{array}$ \\
\hline \multirow{2}{*}{\multicolumn{19}{|c|}{ Buruk }} \\
\hline 6. $\quad$ Kontrol Bunyi & & & & & & & & & & & & & & & & & & \\
\hline Sangat Baik & & & & & & & & & & & & & & $\mathrm{V}$ & & & & $\begin{array}{l}\text { Mempertahankan kondisi yang } \\
\text { telah ada }\end{array}$ \\
\hline Baik & $\mathrm{v}$ & & $\mathrm{V}$ & $\mathrm{V}$ & $\mathrm{V}$ & & & $\mathrm{v}$ & $\mathrm{V}$ & $\mathrm{v}$ & $\mathrm{v}$ & $\mathrm{v}$ & & & $\mathrm{v}$ & $\mathrm{V}$ & $\mathrm{V}$ & $\begin{array}{l}\text { Penanaman kombinasi pohon, } \\
\text { perdu/semak dan penutup tanah }\end{array}$ \\
\hline Sedang & & $\mathrm{V}$ & & & & $\mathrm{v}$ & $\mathrm{V}$ & & & & & & $\mathrm{V}$ & & & & & $\begin{array}{l}\text { Penambahan penanaman } \\
\text { beberapa lapis tanaman di } \\
\text { median dan tepi jalan }\end{array}$ \\
\hline \multicolumn{19}{|l|}{ Buruk } \\
\hline \multicolumn{19}{|c|}{ 7. Kontrol Polusi } \\
\hline Sangat Baik & & & & & & & & & & & & & & & & & & $\begin{array}{l}\text { Mempertahankan kondisi yang } \\
\text { telah ada }\end{array}$ \\
\hline
\end{tabular}




\begin{tabular}{|c|c|c|c|c|c|c|c|c|c|c|c|c|c|c|c|c|c|c|}
\hline \multirow[t]{3}{*}{ Fungsi } & \multicolumn{17}{|c|}{ Jalan dan Segmen } & \multirow[t]{3}{*}{ Rekomendasi } \\
\hline & \multicolumn{4}{|c|}{ Cut Nyak Dien } & \multicolumn{8}{|c|}{ Sudirman } & \multirow{2}{*}{$\begin{array}{l}\text { Gajah } \\
\text { Mada } \\
1\end{array}$} & \multicolumn{4}{|c|}{ Diponegoro } & \\
\hline & 1 & 2 & 3 & 4 & 1 & 2 & 3 & 4 & 5 & 6 & 7 & 8 & & 1 & 2 & 3 & 4 & \\
\hline Baik & $\mathrm{V}$ & & $\mathrm{v}$ & $\mathrm{v}$ & $\mathrm{v}$ & $\mathrm{V}$ & $\mathrm{V}$ & & $\mathrm{V}$ & $\mathrm{V}$ & $\mathrm{V}$ & & & $\mathrm{V}$ & & $\mathrm{V}$ & $\mathrm{V}$ & $\begin{array}{l}\text { Penanaman beberapa lapis } \\
\text { tanaman berkapasitas } \\
\text { mengurangi polutan }\end{array}$ \\
\hline Sedang & & $\mathrm{v}$ & & & & & & $\mathrm{V}$ & & & & $\mathrm{v}$ & $\mathrm{V}$ & & $\mathrm{v}$ & & & $\begin{array}{l}\text { Penambahan penanaman } \\
\text { tanaman yang dapat mengurangi } \\
\text { polutan }\end{array}$ \\
\hline Buruk & & & & & & & & & & & & & & & & & & \\
\hline
\end{tabular}

Tabel 37. Rekomendasi Aspek Estetika Tanman Lanskap Jalan

\begin{tabular}{|l|l|}
\hline \multicolumn{1}{|c|}{ Penataan Tanaman } & \\
\hline 1. Pohon Massal Sejenis & \multicolumn{1}{|c|}{ Rekomendasi } \\
\hline Tinggi & Mempertahankan kondisi yang telah ada \\
\hline Sedang & Meningkatkan pemenuhan kriteria yang lebih baik \\
\hline rendah & Perbaikan penanaman pohon \\
\hline \multicolumn{1}{|c|}{ Pohon Kelompok Campuran } & \\
\hline Tinggi & Mempertahankan kondisi yang telah ada \\
\hline Sedang & Meningkatkan keharmonisan antar pohon \\
\hline rendah & Perbaikan pemilihan pohon kelompok campuran \\
\hline 3. Massal Campuran (pohon-perdu-penutup tanah) & \\
\hline Tinggi & Mempertahankan kondisi yang telah ada \\
\hline Sedang & Meningkatkan keseimbangan kombinasi tanaman \\
\hline rendah & Meningkatkan keseimbangan dan perbaikan penataan kombinasi tanaman \\
\hline \multicolumn{2}{|l|}{} \\
\hline
\end{tabular}


Tabel 38. Rekomendasi Aspek Pengelolaan Tanaman Lanskap Jalan

\begin{tabular}{|c|c|c|c|c|c|c|c|c|c|c|c|c|c|c|c|c|c|c|}
\hline \multirow[t]{3}{*}{ Fungsi } & \multicolumn{17}{|c|}{ Jalan dan Segmen } & \multirow[t]{3}{*}{ Rekomendasi } \\
\hline & \multicolumn{4}{|c|}{ Cut Nyak Dien } & \multicolumn{8}{|c|}{ Sudirman } & \multirow{2}{*}{$\begin{array}{c}\begin{array}{c}\text { Gajah } \\
\text { Mada }\end{array} \\
1 \\
\end{array}$} & \multicolumn{4}{|c|}{ Diponegoro } & \\
\hline & 1 & 2 & 3 & 4 & 1 & 2 & 3 & 4 & 5 & 6 & 7 & 8 & & 1 & 2 & 3 & 4 & \\
\hline \multicolumn{19}{|c|}{ 3. $\quad$ Segi Desain } \\
\hline Sangat Baik & & & & & & & & & & $\mathrm{v}$ & & & & & & & & $\begin{array}{l}\text { Mempertahankan kondisi yang } \\
\text { telah ada }\end{array}$ \\
\hline Baik & & $\mathrm{v}$ & & $\mathrm{v}$ & & $\mathrm{v}$ & $\mathrm{v}$ & & & & $\mathrm{v}$ & $\mathrm{v}$ & & & & & & Penataan tanaman secara massal \\
\hline Sedang & $\mathrm{v}$ & & $\mathrm{v}$ & & $\mathrm{v}$ & & & $\mathrm{v}$ & $\mathrm{v}$ & & & & $\mathrm{v}$ & $\mathrm{v}$ & $\mathrm{v}$ & $\mathrm{v}$ & $\mathrm{v}$ & $\begin{array}{l}\text { Penggunaan pola tanaman yang } \\
\text { sederhana }\end{array}$ \\
\hline \multirow{2}{*}{\multicolumn{19}{|c|}{$\begin{array}{l}\text { Buruk } \\
\text { 4. Segi Teknik }\end{array}$}} \\
\hline & & & & & & & & & & & & & & & & & & \\
\hline \multicolumn{19}{|c|}{ Sangat Baik } \\
\hline Baik & $\mathrm{v}$ & $\mathrm{v}$ & $\mathrm{v}$ & $\mathrm{v}$ & $\mathrm{v}$ & $\mathrm{v}$ & $\mathrm{v}$ & $\mathrm{v}$ & $\mathrm{v}$ & $\mathrm{v}$ & $\mathrm{v}$ & $\mathrm{v}$ & $\mathrm{v}$ & $\mathrm{v}$ & $\mathrm{v}$ & $\mathrm{v}$ & $\mathrm{v}$ & $\begin{array}{l}\text { Dipertahankan, peningkatan } \\
\text { penyulaman }\end{array}$ \\
\hline \multicolumn{19}{|l|}{ Sedang } \\
\hline Buruk & & & & & & & & & & & & & & & & & & \\
\hline
\end{tabular}




\section{SIMPULAN DAN SARAN}

\section{Simpulan}

Dari hasil evaluasi fungsi, pengelolaan dan estetika tata hijau jalur hijau jalan kota pekanbaru dapat disimpulkan beberapa hal, sebagai berikut :

1. Tata hijau pada jalur hijau jalan Kota Pekanbaru didominasi oleh deretan pohon mahoni, angsana dan bintaro. Deretan pohon berjejer di sepanjng jalan ada yang telah tumbuh dalam jangka waktu lama ada juga yang baru ditanam. Terdapat juga kombinasi pohon, perdu dan penutup tanah yang menghiasi median jalan dan juga bundaran jalan.

2. Penelitian terhadap aspek fungsi tanaman pada jalur hijau jalan didapatkan untuk fungsi tanaman termasuk kedalam kategori sangat baik yaitu jalan Sudirman segmen $6(81,9 \%)$ yang memenuhi semua kriteria fungsi seperti ditanam rapat, massal, berkesinambungan sepanjang jalan. Fungsi tanaman dengan kategori baik berjumlah 13 segmen jalan denga nilai antara 65,2\% 78,9\%. Pada kategori ini penataan tanaman sudah baik tetapi diperlukan peningkatan kriteria fungsi agar menjadi lebih baik. Fungsi tanaman dengan kategori sedang terdiri dari 3 segmen yaitu Jalan Cut Nyak Dien segmen 2 (49,5\%), jalan Gajah Mada (59,4\%) dan Jalan Diponegoro segmen 2 (59,6\%). Segmen dengan kategori sednag memiliki tanaman yang ditanam dengan jarak renggang dan tidak berkesinambungan. Dibutuhkan penambahan tanaman untuk memenuhi kriteria fungsi tanaman.

3. Hasil penelitian terhadap aspek pengelolaan memperlihatkan untuk segmen jalan yang termasuk ke dalam kategori baik berjumlah 16 segmen (hampir semua dalam pengelolaan yang baik) dengan kisaran nilai 56,3\% - 77,1\%. Pengelolaan yang dilihat dari bentukan tanaman yang rapi dan indah, dan penampakan tanaman yang baik dari segi warna daun dan bunga. Pemeliharaan perlu untuk dipertahankan dan ditingkatkan. Pada segmen jalan yang termasuk ke kategori sedang yaitu Jalan sudirman segmen 4 (56,3\%). Perlu pengelolaan yang lebih teratur dan desain penanaman yang sederhana yang mudah dalam pemeliharaannya. 
4. Hasil penelitian estetika menggunakan teknik SBE didapatkan untuk penataan tanaman pohon massal sejenis dengan kategori tinggi disebabkan penanaman pohon sejenis secara massal berkesinambungan dengan jarak rapat, sehingga terlihat seragam dan unity. Pada pohon massal campuran dengan kategori nilai tinggi, kombinasi pohon yang dipilih serasi, bentuk tajuk, tekstur, warna dan ukuran. Variasi yang sesuai dan tidak teralalu banyak, keseimbangan dan unity tercipta. Pada massal campuran (pohon-perdu-penutup tanah) dengan kategori nilai tinggi dengan kriteria penanaman terpenuhi seperti, kombinasi yang seimbang dan serasi dalam ukuran, warna dan tekstur. Penataan yang rapi, kombinasi dan proporsi yang seimbang menciptakan suatu harmonisasi lanskap yang indah. Lanskap keindahan tinggi perlu untuk dipertahankan. Pada penataan berkategori sedang, dan rendah, penataan yang tidak seimbang dalam hal kombinasi dan proporsi tanaman sehingga dibutuhkan peningkatan, perbaikan, dan penambahan tanaman agar memenuhi kategori penanaman yang baik.

\section{Saran}

Penanaman tanaman pada jalur hijau jalan perlu untuk memperhatikan fungsi dari tanaman tersebut. Fungsi tanaman sebagai pengarah, peneduh, pembatas visual, pemberi identitas, kontrol polusi, kontrol silau matahari, dan kontrol bunyi. Jalur hijau jalan perlu memiliki tanaman dengan fungsi tersebut, untuk memenuhi fungsi tersebut perlu untuk memperhatikan dan memenuhi kriteria tiap fungsi tanaman. Pada penanaman di lapang juga perlu memperhatikan pola desain penanaman, desain penanaman yang sederhana akan mempermudah dalam pemeliharaannya. Pada penanaman pohon massal sejenis, pohon campuran ataupun massal campuran (kombinasi pohon, perdu, penutup tanah) di lapang perlu untuk memperhatikan unity dan balance agar tercipta suatu harmonisasi. Komposisi dan proporsi tanaman juga perlu untuk diperhatikan. Pemeliharaan secra teknis dengan jadwal teratur dibutuhkan untuk menjaga keberlanjutan fungsi tanaman agar dapat dinikmati visual yang indah dan dapat dirasakan kegunaannya oleh pengguna jalan. Penanaman pohon dapat menggunakan tanaman asli daerah sebagai identitas daerah. 


\section{DAFTAR PUSTAKA}

Arifin, H.S. dan Arifin. 2000. Pemeliharaan Taman. Penebar Swadaya. Jakarta.123 hal.

Aris, A. 2005. Evaluasi Vegetasi Lanskap Jalan Kawasan Pariwisata Nusa Dua, Bali. Skripsi. Jurusan BDP. Faperta. IPB. Tidak dipublikasikan.

Austin, L.R. 1982. Designing With Plants. Van Norstrand Reinhold Co. Inc. New York. 168p.

Booth, N.K. 1983. Basic Elements of Landscape Architectural Design. Waveland Press Inc. 315p.

Carpenter, P.L., Walker, T.D., and Lanphear, F.O. 1975. Plants in the Landscape. W. H. Freeman and Co. San Fransisco. 481 p.

Daniel, T.C. and Boster, R.S. 1976. Measuring Landscape Aesthetics : the Scenic Beauty Estimation Metho. USDA Forest Service Research Paper. RM$167.66 \mathrm{p}$.

De Chiara, J. dan L.E. Koppelman. 1987. Standar Perencanaan Tapak (terjemahan). Penerbit Erlangga. Jakarta. 380 hal.

Departemen Pekerjaan Umum.1996. Tata Cara Perencanaan teknik Lanskap Jalan. Direktorat Jenderal Bina Marga. Jakarta.

Echols, J.M. dan Shadily, H. 1996. An English- Indonesian Dictionary. Cornell University Press Ithaca and London. 660 p.

Hidayat, I.W. 2008. Evaluasi Jalur Hijau Jalan sebagai Penyangga Lingkungan Sekitarnya dan Keselamatan Penggunaan Jalan Bebas Hambatan. Tesis. Program Pascasarjana IPB. Tidak dipublikasikan.

Hackett, B. 1982. Planting Design. E \& F. N Spon Ltd. London. 174 p.

Laurie, M. 1975. An Introduction to Landscape Architecture. American Elsevier Publ. Co. Inc. New York. 214p.

Lestari, G. dan Ira, P.K. 2008. Galeri Tanaman Hias Lanskap. Penebar Swadaya. Jakarta. 277hal.

Nizar, N., Suharsono H., Wungkar M., dan Gunawan A. 1997. Studi Kemampuan Tanaman Jalan Raya dalam Menyerap Polusi Udara $\left(\mathrm{NO}_{2}\right)$. Laporan Riset RUT. Dewan Riset Nasional Kantor Menteri Negara Riset dan Teknologi. Jakarta. 34 hlm.

Reid, G.W. 1993.From Concept to Form. Van Norstrand Reinhold. New York. $162 \mathrm{p}$.

Simonds, J.O. 1983. Landscape Architecture. Mc Graw Hill Book Co. New York. $301 \mathrm{p}$.

Stevens, D., Huntington, L., and Key, R. 1994. Garden Design, Construction and Planting. Ward Lock. London. 256p.

Sulistyantara, B. 2002. Tanaman Rumah Tinggal. Penebar Swadaya. Jakarta. 194hal. 
Vitasari, D. 2004. Evaluasi Tata Hijau Jalan Pada Tiga Kawasan Pemukiman Besar di Kabupaten Bogor, Jawa Barat. Skripsi. Jurusan BDP. Faperta. IPB. Bogor. Tidak dipublikasikan.

Wungkar, M.M. 2005. Evaluasi Aspek Fungsi dan Kualitas Estetika Arsitektural Pohon Lanskap Jalan Kota Bogor. Tesis.Progran Pascasarjana IPB. Tidak dipublikasikan.

www.wikipedia.com-kota-Wikipedia-Indonesia, ensiklopedia bebas berbahasa Indonesia.htm. (akses 24 Maret 2007). 


\section{Lampiran 1. Kuesioner Penilaian Estetika Tanaman Lanskap Jalan KUESIONER \\ Evaluasi Kualitas Estetika Penataan Tanaman Lanskap Jalan Kota Pekanbaru \\ Skala Penilaian Responden}

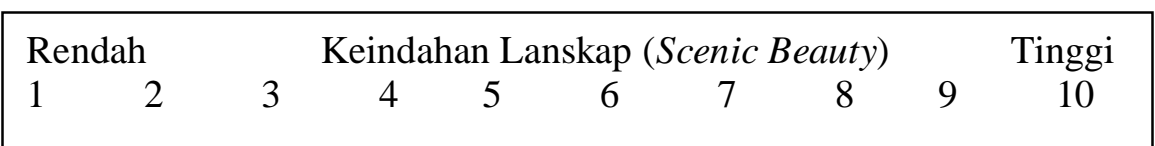

A. Pohon Massal Sejenis

Penilaian Lanskap

01.

02.

03.

04.

05.

06.

B.

01.

02.

03 .

C.

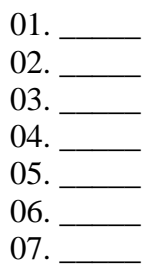

07.

08.

09.

10.

11.

12.

Pohon Kelompok Campuran

Penilaian Lanskap

04.

05.

06.

06.

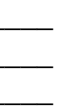

07.

08.

09.
6.

18.

4.

5.
19.

20.

21.

22.

Massal Campuran (Pohon-Perdu-Penutup Tanah) Penilaian Lanskap

Identitas Responden

08 .

09.

10.

11.

12.

13.

14.
15.

16.

17.

18.

19.

20.

21.
10.

11.

12.

Umur

Jenis Kelamin

Semester

Komentar 
Lampiran 2. Tanaman LAnskap Yang berpotensi Tinggi Menyerap Polutan Gas $\mathrm{NO}_{2}$

\begin{tabular}{|c|c|c|c|}
\hline No & Nama Ilmiah & Nama Lokal & Serapan $\mathrm{NO}_{2}$ \\
\hline \multicolumn{4}{|c|}{ Pohon } \\
\hline 1 & Erythrina variegate & Dadap kuning & Tinggi \\
\hline 2 & Canamga odorata & Kenanga & Tinggi \\
\hline 3 & Gnetum gnemon & Melinjo & Tinggi \\
\hline 4 & Calliandra surinensis & Kaliandra & Tinggi \\
\hline 5 & Delonix regia & Flamboyant & Tinggi \\
\hline 6 & Caesalpinia pulcherima & Kembang merak & Tinggi \\
\hline 7 & Diallium indum & Asam keranji & Tinggi \\
\hline 8 & Ceiba pentandra & Kapuk & Tinggi \\
\hline 9 & Bixa oreliana & Galinggem & Tinggi \\
\hline 10 & Brownea capitella & Bunga lampion & Tinggi \\
\hline 11 & Samanea saman & Ki hujan & Tinggi \\
\hline 12 & Michelia champaca & Cempaka & Tinggi \\
\hline 13 & Psidium guajava & Jambu biji & Tinggi \\
\hline 14 & Cassia multijuga & Hujan mas & Tinggi \\
\hline 15 & Atrocarpus integra & Nangka & Tinggi \\
\hline 16 & Casuarinas equisetifolia & Cemara angin & Sedang \\
\hline 17 & Khaya senegaiensis & Pohon kaya & Sedang \\
\hline 18 & Terminalis catappa & Ketapang & Sedang \\
\hline 19 & Spathodea campanulata & Spathodea & Sedang \\
\hline 20 & Bauhinia purpurea & Bunga kupu-kupu & Sedang \\
\hline 21 & Pterpcarpus indicus & Angsana & Sedang \\
\hline 22 & Arundinaria $s p$ & Bamboo jepang & Sedang \\
\hline 23 & Mangifera indica & Mangga & Sedang \\
\hline 24 & Saraka indica & Asoka & Sedang \\
\hline 25 & Eucalyptus alba & Kayu putih & Sedang \\
\hline 26 & Cassia biflora & Kasia golden & Sedang \\
\hline 27 & Areca catechu & Pinang jambe & Sedang \\
\hline 28 & Cassia sp & Ayuga & Sedang \\
\hline 29 & Barringtonia asiatica & Keben & Sedang \\
\hline 30 & Lansium domesticum & Duku & Sedang \\
\hline 31 & Polyathia fragrans & Glodogan bulat & Sedang \\
\hline 32 & Mangifera caesia & Kemang & Sedang \\
\hline 33 & Cinnamon burmanii & Kayu manis merah & Sedang \\
\hline 34 & Caryota mitis & Palem ekor ikan & Sedang \\
\hline 35 & Veitchia merili & Palem putrid & Sedang \\
\hline 36 & Elaeis guinensis & Kelapa sawit & Sedang \\
\hline 37 & Casuarinas sumatrana & Cemara balon & Sedang \\
\hline 38 & Scheffiera actinophylla & Wali songo & Sedang \\
\hline 39 & Mimusops elengi & Tanjung & Sedang \\
\hline 40 & Cocos nucifera capitata & Kelapa gading & Sedang \\
\hline 41 & Agathis damara & Dammar & Rendah \\
\hline 42 & Cocos nicifera & Kelapa & Rendah \\
\hline 43 & Durio zibethinus & Durian & Rendah \\
\hline 44 & Cinnamoтиm zayianicum & Kayu manis hijau & Rendah \\
\hline 45 & Juniperus sinensis & Cemara tiang & Rendah \\
\hline 46 & Nephelium lappaceum & Rambutan & Rendah \\
\hline 47 & Acacia auriculiormis & Akasia & Rendah \\
\hline 48 & Nephelium longanum & Lengkeng & Rendah \\
\hline 49 & Laucaena glauca & Lamtoro & Rendah \\
\hline
\end{tabular}




\begin{tabular}{|c|c|c|c|}
\hline 50 & Ryostenea regia & Palem raja & Rendah \\
\hline 51 & Dillenia philipinensis & Sempur & Rendah \\
\hline 52 & Livistonia rotundiflora & Palem sadeng & Rendah \\
\hline 53 & Ficus benjamina & Berimgin & Rendah \\
\hline 54 & Cassia siamea & Johar & Rendah \\
\hline 55 & Ficus elastic & Beringin karet & Rendah \\
\hline 56 & Podocarpus nerifolius & Ki putrid & Rendah \\
\hline 57 & Shorea leprosula & Meranti & Rendah \\
\hline 58 & Myristica fragrans & Pala & Rendah \\
\hline 59 & Cyrtostachys lakka & Palem merah & Rendah \\
\hline 60 & Cupressus papuana & Cemara papua & Rendah \\
\hline 61 & Cyanometra cauliflora & Nam-nam & Rendah \\
\hline 62 & Canarium communae & Kenari & Rendah \\
\hline 63 & Lagerstomia loudonii & Bungur & Rendah \\
\hline 64 & Manilkara kauki & Sawo kecik & Rendah \\
\hline 65 & Phyllostachys sulphurea & Bambu kuning & Rendah \\
\hline 66 & Araucaria exeisa & Cemara norflok & Rendah \\
\hline 67 & Mascarena laganecaulis & Palem botol & Rendah \\
\hline 68 & Polyathia longifolia & Glodogan tiang & Rendah \\
\hline 69 & Felicium decipiens & Kiara paying & Rendah \\
\hline 70 & Phyticosperma macarthurii & Palem hijau & Rendah \\
\hline 71 & Thuja orientalis & Cemara kipas & Rendah \\
\hline 72 & Acacia mangium & Akasia mangium & Rendah \\
\hline \multicolumn{4}{|c|}{ Semak } \\
\hline 1 & Jacobina carnea & Lollipop merah & Tinggi \\
\hline 2 & Malpinghia sp & Akalipa merah & Tinggi \\
\hline 3 & Acalypha wilkisiena & Lollipop kuning & Tinggi \\
\hline 4 & Pachystachys lutea & Nusa indah merah & Tinggi \\
\hline 5 & Mussaendah erythrophylla & Daun mangkokan & Tinggi \\
\hline 6 & Notophanax scltellarium & Bogenvil merah & Tinggi \\
\hline 7 & Bougenvillea glabra & Kacapiring & Tinggi \\
\hline 8 & Gardenia augusta & Miana & Tinggi \\
\hline 9 & Coleus blumei & Hanjuang merah & Tinggi \\
\hline 10 & Cordyline terminalis & Azalea & Tinggi \\
\hline 11 & Rhododendron indicum & Lanta & Tinggi \\
\hline 12 & Lantana camara & Akalipa hijau-putih & Tinggi \\
\hline 13 & Acalypha wilkesiana & Sirih belanda & Tinggi \\
\hline 14 & Scindapsus aureus & Ixora daun besar & Sedang \\
\hline 15 & Alpinia purpurea & Kedondong laut & Sedang \\
\hline 16 & Ixora javanica & Bakung & Sedang \\
\hline 17 & Notophanax sarcophagus & Bunga mentega & Sedang \\
\hline 18 & Crinum asiaticum & Palem kuning & Sedang \\
\hline 19 & Nerium oleander & Kana & Sedang \\
\hline 20 & Chrysalidocarpus lutescens & Bayam merah & Sedang \\
\hline 21 & Canna indica & Keladi & Sedang \\
\hline 22 & Iresine herbstii & Drasena & Sedang \\
\hline 23 & Caladium hortulanum & Alamanda & Sedang \\
\hline 24 & Dracaena fragfrans & Bunga pukul empat & Sedang \\
\hline 25 & Allamanda cathartica & Heliconia merah & Sedang \\
\hline 26 & Mirabilis jalapa & Bluntas & Sedang \\
\hline 27 & Heliconia psittacorum & Sikas & Sedang \\
\hline 28 & Plutea indica & Gandarosa & Sedang \\
\hline 29 & Cycas revulata & Bamboo pangkas & Sedang \\
\hline 30 & Gandarosa vulgaris & Plumbago & Sedang \\
\hline
\end{tabular}




\begin{tabular}{|c|c|c|c|}
\hline 31 & Arundinaria pumila & Palem kol & Sedang \\
\hline 32 & Plumbago indica & Daun dolar & Rendah \\
\hline 33 & Licuala grandis & Nusa indah putih & Rendah \\
\hline 34 & Ficus repens & Agave hijau & Rendah \\
\hline 35 & Mussaenda alba & Pleomele & Rendah \\
\hline 36 & Agave sisaiana & Passiflora & Rendah \\
\hline 37 & Pleomele variegate & Bogenvil oranye & Rendah \\
\hline 38 & Passiflora cocinea & Amarilis & Rendah \\
\hline 39 & Bougenvillea spectabilis & Agave kuning & Rendah \\
\hline 40 & Hippeastrum amaryllis & Sri rejeki & Rendah \\
\hline 41 & Agave Americana & Keladi hias & Rendah \\
\hline 42 & Aglonema nitidium & Stephanut & Rendah \\
\hline 43 & Calafium bicolor & Pisang hias & Rendah \\
\hline 44 & Stephanotis floribunda & Mawar & Rendah \\
\hline 45 & Heliconia rosrata & Pakis haji & Rendah \\
\hline 46 & Rosa chinensis & Mirten & Rendah \\
\hline 47 & Cycas rumphii & Pangkas kuning & Rendah \\
\hline 48 & Malphigia coccigyera & Sambaing darah & Rendah \\
\hline 49 & Duranta repens & Kemuning & Rendah \\
\hline 50 & Excoecaria bicolor & Sambaing merah & Rendah \\
\hline 51 & Muraya paniculata & Kemuning & Rendah \\
\hline 52 & Salvia splendens & Salvia merah & Rendah \\
\hline 53 & Durata variegate & Terang bulan & Rendah \\
\hline 54 & Ixora chinensis & Ixora daun kecil & Rendah \\
\hline 55 & Rhapis exelsa & Palem wregu & Rendah \\
\hline 56 & Phyllanthus niruri & Cendrawasih & Rendah \\
\hline 57 & Hibiscus rosasinensis & Kembang sepatu & Rendah \\
\hline 58 & Eugenia uniflora & Sianto & Rendah \\
\hline \multicolumn{4}{|c|}{ Rumput } \\
\hline 1 & Alternantera ficoides & Kriminil merah & Sedang \\
\hline 2 & Zoysia matrella & Rumput manila & Sedaang \\
\hline 3 & Rhoeo discolor & Adam hawa & Sedang \\
\hline 4 & Cynodon dactilon & Rumput kawat/golf & Rendah \\
\hline 5 & Axonophus compressus & Rumput paitan & Rendah \\
\hline 6 & Alternanthera amoena & Kriminil putih & Rendah \\
\hline 7 & Cuphea mycrophylla & Taiwan putih & Rendah \\
\hline 8 & Chlorophytum comosum & Chlorophytum hijau & Rendah \\
\hline 9 & Philea cardierei & Mutiara & Rendah \\
\hline 10 & Chlorophytum bachestii & Chlorophytum putih & Rendah \\
\hline 11 & Ophiopogon jaburan & Lili paris putih & Rendah \\
\hline
\end{tabular}

Tanaman dikalsifikasikan kedalam tiga tingkatan serapan $\mathrm{N}$ :

1. Serapan tinggi $=$ tanaman yang memilki serapan $\mathrm{N}>30,00 \mu \mathrm{g} / \mathrm{g}$

2. Serapan sedang $=$ tanaman yang memilki serapan $N 15-30 \mu \mathrm{g} / \mathrm{g}$

3. Serapan rendah $=$ tanaman yang memiliki serapan $\mathrm{N}<15,00 \mu \mathrm{g} / \mathrm{g}$ 